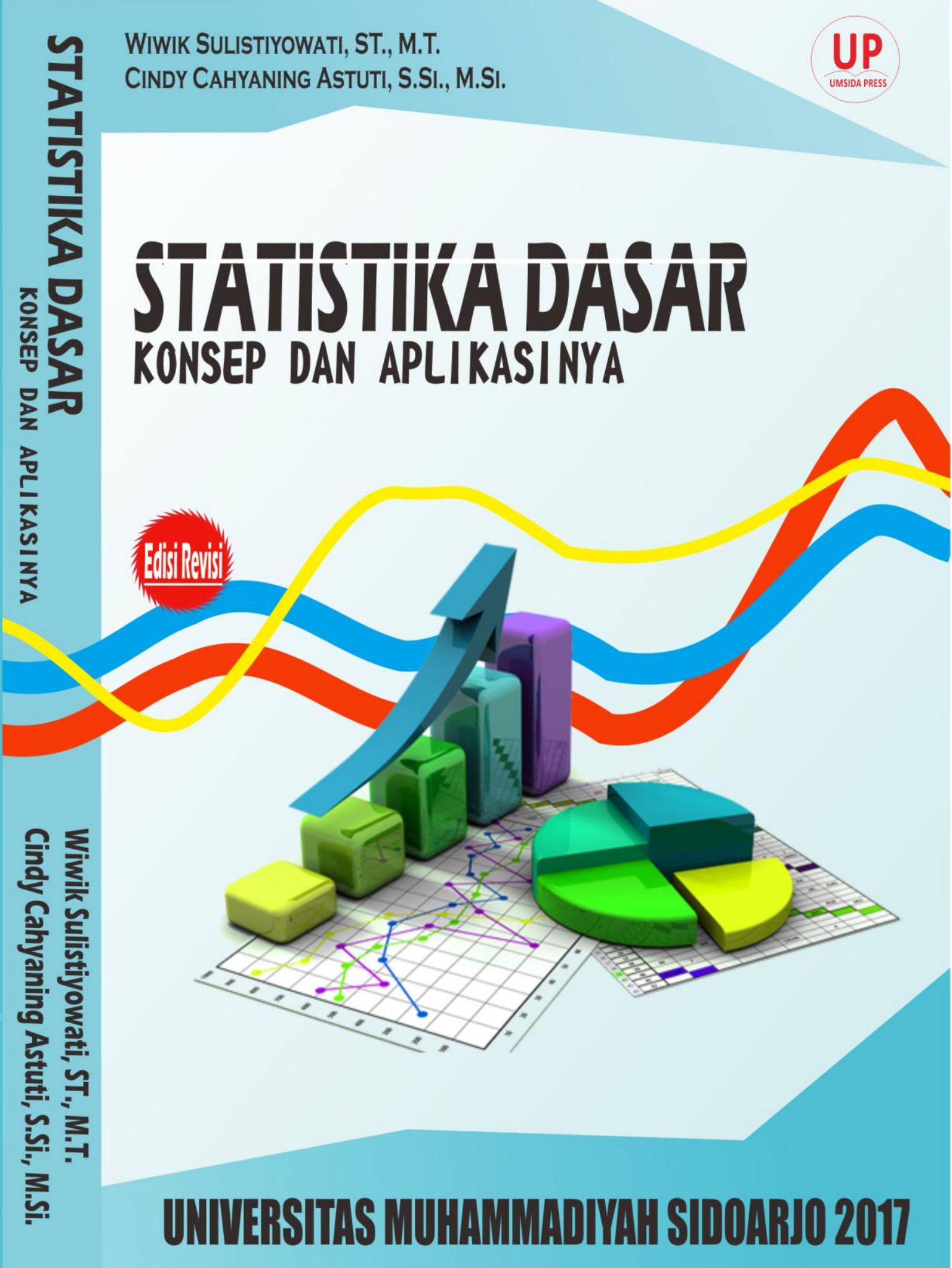




\title{
BUKU AJAR STATISTIKA DASAR
}

\section{Penulis}

Wiwik Sulistiyowati, ST., M.T.

Cindy Cahyaning Astuti, S.Si., M.Si.

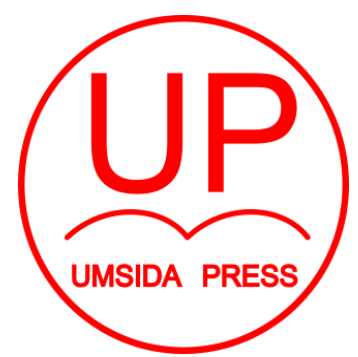

\author{
Diterbitkan oleh \\ UMSIDA PRESS \\ Jl. Mojopahit 666 B Sidoarjo \\ ISBN: \\ Copyright@2017. \\ Authors \\ All rights reserved
}




\section{BUKU AJAR}

\section{STATISTIKA DASAR}

\section{Penulis :}

Wiwik Sulistiyowati, ST., M.T.

Cindy Cahyaning Astuti, S.Si., M.Si.

\section{ISBN :}

\section{Editor :}

Septi Budi Sartika, M.Pd

M. Tanzil Multazam, S.H., M.Kn.

\section{Copy Editor :}

Fika Megawati, S.Pd., M.Pd.

\section{Design Sampul dan Tata Letak :}

Mochamad Nashrullah, S.Pd

\section{Penerbit :}

UMSIDA Press

\section{Redaksi :}

Universitas Muhammadiyah Sidoarjo

Jl. Mojopahit No 666B

Sidoarjo, Jawa TImur

\section{Cetakan kedua, Agustus 2017}

(C) Hak cipta dilindungi undang-undang

Dilarang memperbanyak karya tulis ini dengan suatu apapun tanpa ijin tertulis dari penerbit. 


\section{KATA PENGANTAR}

Dengan mengucapkan puji syukur Allhamdullillah, atas berkat rahmat Allah SWT, kami dapat menyelesaikan buku ajar dengan judul "Statistik Dasar edisi Revisi". Kami selaku tim penyusun mengucapkan terima kasih kepada semua pihak yang telah membantu kami selama proses pelaksanaan penyusunan sampai dengan terselesainya buku ajar ini. Kami menyadari, dalam buku ajar yang kami susun masih banyak kekurangan, sehingga kami berharap pembaca dan pengguna dapat memberikan masukkan/ kritik yang sifatnya membangun. Semoga apa yang kami hasilkan ini dapat memberikan manfaat bagi pembaca dan mahasiswa.

Penyusun 


\section{DAFTAR ISI}

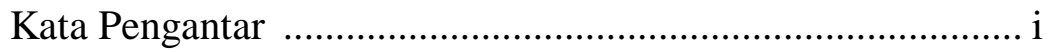

Daftar Isi........................................................................ ii

\section{BAB 1 PENDAHULUAN}

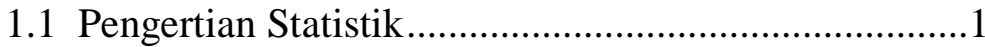

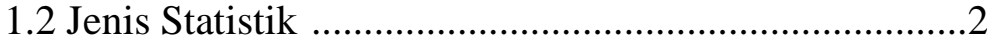

1.3 Elemen Dasar Statistik ...............................................

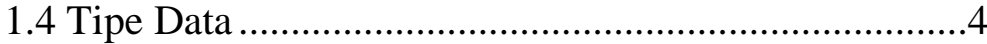

1.5 Skala Pengukuran Data ...............................................

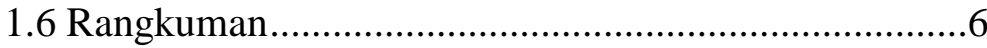

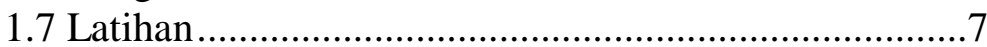

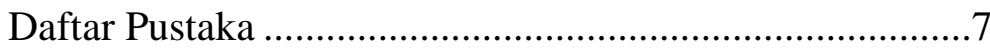

\section{BAB 2 PENYAJIAN DATA}

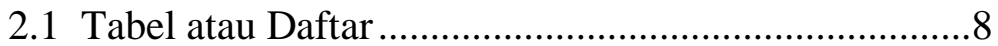

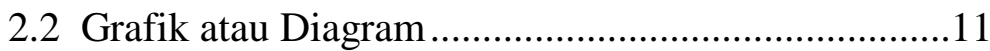

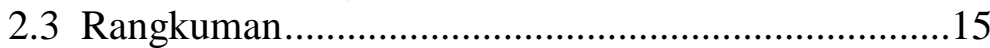

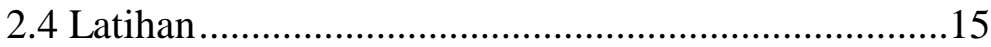

Daftar Pustaka ...................................................................16

\section{BAB 3 DISTRIBUSI FREKUENSI}

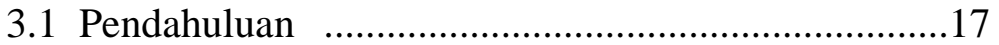

3.2 Tahapan Pembuatan Tabel Frekuensi..........................19

3.3 Frekuensi Relatif dan Frekuensi Kumulatif ...............22

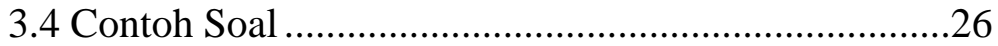

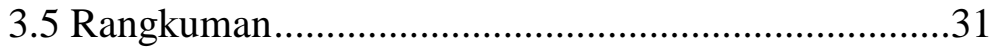

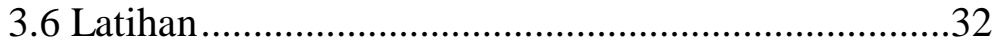

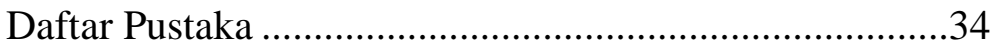

BAB 4 UKURAN, PEMUSATAN DAN 


\section{PENYIMPANG DATA}

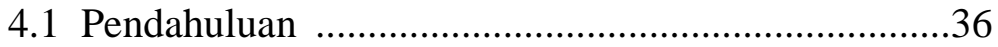

4.2 Jenis Ukuran Pemusatan Data ....................................37

4.3 Jenis Ukuran Penyimpangan Data................................43

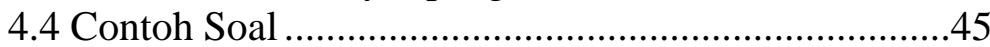

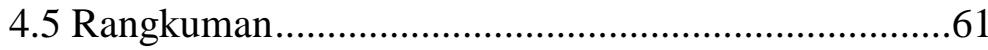

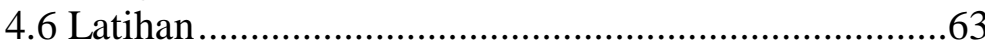

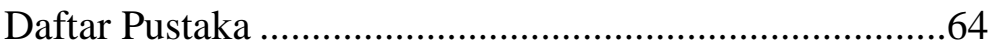

\section{BAB 5 PROBABILITAS}

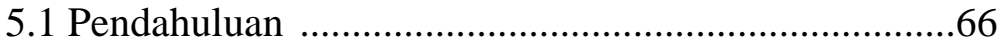

5.2 Konsep Probabilitas ..................................................67

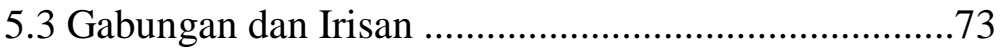

5.4 Probabilitas Bersyarat ...................................................73

5.5 Aturan Perkalian dan Peristiwa Independen ................74

5.6 Berbagai ATuran Perhitungan atau Pencacahan ..........75

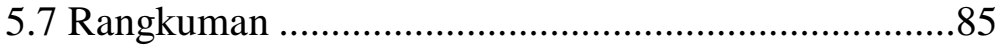

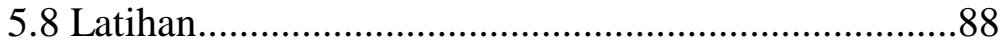

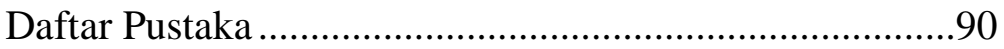

\section{BAB 6 DISTRIBUSI NORMAL}

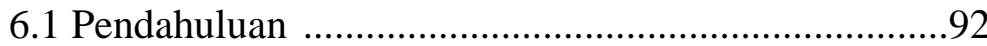

6.2 Sifat-sifat Distribusi Normal ......................................93

6.3 Penggunaan Distribusi Normal ...................................95

6.4 Transformasi Distribusi Normal .................................97

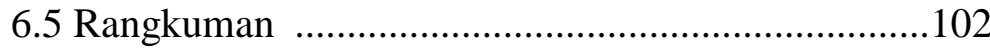

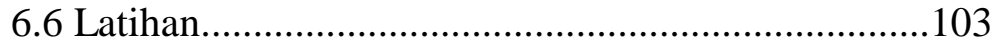

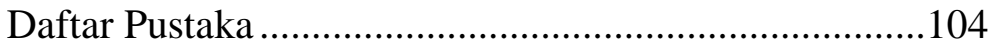

\section{BAB 7 HIPOTESA}

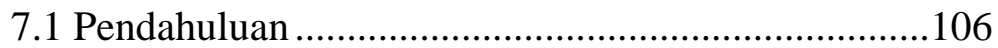

7.2 Dua Jenis Kesalahan Hipotesa ..................................107

7.3 Langkah-langkah Pengujian Hipotesa........................109

7.4 Pengujian Hipotesa.........................................................109 


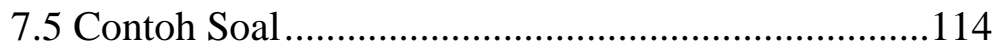

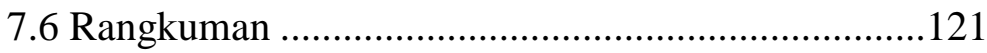

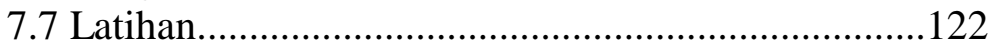

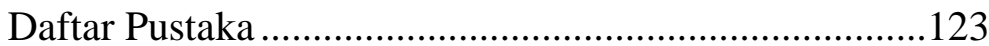

\section{BAB 8 REGRESI DAN KORELASI}

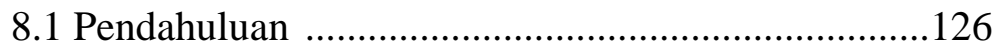

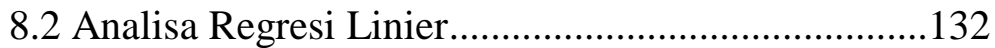

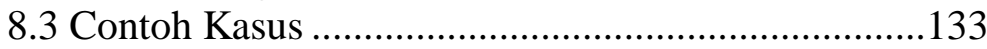

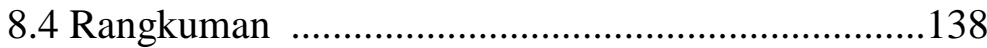

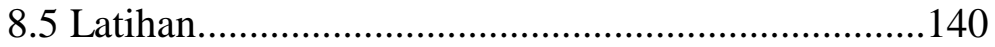

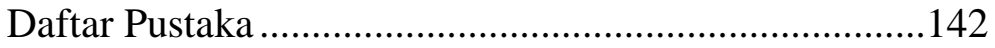

\section{BAB 9 PENGUJIAN ASUMSI DAN ANALISA} REGRESI

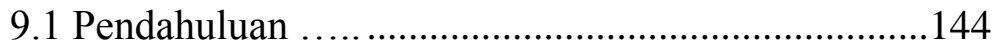

9.2 Pengujian Asumsi Analisis Regresi menggunakan Software Minitab.........................................................146

9.2.1 Analisis Regresi ...................................................146

9.2.2 Pengujian Normalitas .............................................153

9.3 Pengujian Non - Heterokedastisitas............................159

9.4 Uji Non-Autokorelasi................................................165

9.5 Uji Non Multikolinieritas...........................................168

9.6 Rangkuman ............................................................171

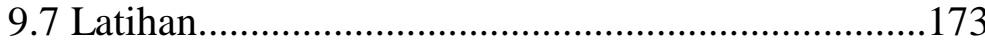

Daftar Pustaka ...............................................................174

BAB 10 ANALISA RAGAM

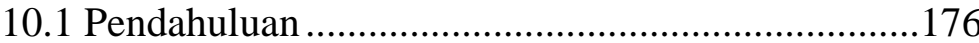

10.2 Analisa Ragam Satu Arah .....................................177

10.3 Uji Homogenitas ....................................................188

10.4 Analisa Ragam Dua Arah.......................................190

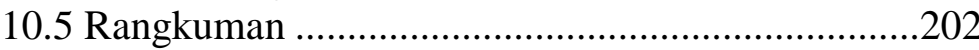

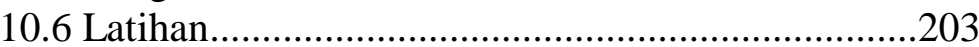

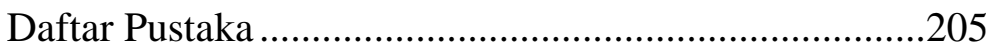

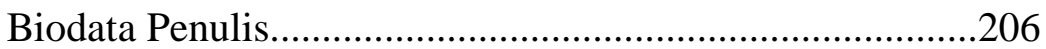




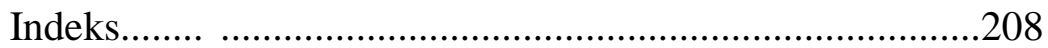

LAMPIRAN

Lampiran 1. Tabel Distribusi Normal ..................................211

Lampiran 2. Tabel Distribusi F ...........................................213

Lampiran 3. Tabel Durbin Watson.....................................225 


\section{BAB 1 \\ PENDAHULUAN}

Peranan statistik dalam aktivitas sehari-hari telah banyak digunakan, baik untuk keperluan sehari-hari di rumah tangga atau keluarga. Salah satunya adalah dalam pembagian pos-pos pengeluaran. Selain itu statistik juga banyak digunakan dalam pemerintahan, industri dan dunia pendidikan. Misalkan untuk dunia pendidikan, statistika digunakan dalam menentuan nilai ketuntasan siswa, baik secara deskriptif maupun secara inferensi.

\subsection{Pengertian Statistik}

Santoso (2004) menyatakan bahwa statistika adalah ilmu yang berkaitan dengan data. Hal-hal yang tercakup dalam statistika adalah pengumpulan, klasifikasi, peringkatan, organisasi, analisis dan interpretasi informasi numerik. Sudjana (2005), menyampaikan bahwa statistik adalah menyatakan kumpulan data, bilangan maupun non bilangan yang disusun dalam tabel dan atau diagram, yang melukiskan atau menggambarkan suatu persoalan, lebih lanjut, sudjana (2005) menambahkan bahwa dengan statistika merupakan pengetahuan yang berhubungan dengan cara-cara pengumpulan data, pengolahan atau 
pengAnalisisannya dan penarikan kesimpulan berdasarkan kumpulan data da penganalisisan yang dilakukan. Spiegel (2004) menyatakan bahwa statistik adalah disipin ilmu yang berhubungan dengan metodemetode ilmiah yang digunakan untuk mengumpulkan, mengolah, meramu, menyajikan dan mengAnalisis data, termasuk juga menarik kesimpulan yang benar dan membuat keputusan secara rasional berdasarkan AnalisisAnalisis tadi. Sehingga dari beberapa ahli yang telah menjelaskan pengertian statistik maka dapat diartikan bahwa statistik adalah suatu ilmu yang digunakan untuk memecahkan suatu permasalahan dengan menggunakan beberapa tahapan yaitu pengumpulan data, pengolahan data, Analisis data dan intepretasi data serta kesimpulan dan keputusan yang diambil berdasarkan Analisis yang telah dilakukan.

\subsection{Jenis Statistik}

Jenis statistik dibedakan menjadi dua, yaitu statistika deskriptif dan statistika inferensi.

a. Statistika Deskriptif yaitu statistika yang menggunakan metode numerik dan grafik untuk mencari pola dalam suatu kumpulan data, meringkas 
informasi yang terkandung dalam kumpulan data, dan menghadirkan informasi dalam bentuk yang diinginkan (Santosa, 2004).

b. Statistika Inferensi yaitu statistik yang menggunakan data sampel untuk membuat estimasi, keputusan, prediksi, dan generalisasi terhadap kumpulan data yang lebih besar (Santoso, 2004).

\subsection{Elemen Dasar Statistika}

Dalam pembelajaran statistik, terdapat elemen-elemen dasar statistika yaitu:

a. Populasi adalah keseluruhan obyek yang akan diteliti. Contoh : Seluruh mahasiswa Universitas Muhammadiyah Sidoarjo

b. Sampel adalah bagian dari populasi.

Contoh : Mahasiswa Fakultas Teknik Universitas Muhammadiyah Sidoarjo.

c. Data adalah sesuatu yang diketahui meskipun belum tentu benar, dimana data dapat digunakan untuk menggambarkan suatu keadaan.

d. Informasi adalah daya yang telah diolah.

e. Variabel adalah karakteristik atau sifat dari unit individual populasi. 


\subsection{Tipe Data}

Dalam ilmu statistik, data dibedakan menjadi dua tipe, yaitu:

a. Data Kualitatif

Pengukuran yang tidak dapat diukur pada skala numerik, dan hanya dapat diklasifikasikan dalam salah satu grup atau kategori.

Contoh : jenis kelamin, tipe kendaraan

b. Data Kuantitatif

Data yang dapat dikodekan dengan skala numerik. Terdapat dua jenis data kuantitatif, yaitu diskrit dan kontinu.

- Diskrit merupakan hasil pencacahan

Contoh : banyaknya mahasiswa yang hadir kuliah, banyaknya sepeda motor yang parkir dihalaman parkir kampus 2.

- Kontinu merupakan hasil pengukuran

Contoh : berat badan mahasiswa, jarak antara kampus 1 dan kampus 2. 


\subsection{Skala Pengukuran Data}

Terdapat empat skala pengukuran data dalam statistik, yaitu:

1. Skala Nominal

Skala yang mempunyai sifat membedakan.

Contoh : Angka 1 menyatakan handphone merk ipod, angka 2 menyatakan handphone merk samsung, angka 3 menyatakan handphone merk lenovo.

\section{Skala Ordinal}

Skala yang mempunyai sifat membedakan dan mengurutkan.

Contoh: Dalam menyebarkan kuesioner, terdapat pembobotan untuk menggambarkan jawaban dari responden dalam memberikan penilaian kualitas pelayanan bank, dimana skala 1 menunjukkan sangat tidak baik, 2 menunjukkan tidak baik, 3 menunjukkan baik dan 4 menunjukkan sangat baik.

3. Skala Interval

Skala yang mepunyai sifat membedakan, mengurutkan, jarak antara nilai tetap dan mempunyai nilai nol yang tidak mutlak. 
Contoh: Waktu tengah hari menunjukkan pukul 12.00, tengah malam menunjukkan pukul 00.00.

4. Skala Rasio

Skala yang empunyai sufat membedakan, mengurutkan, jarak antar nilai tetap dan mempunyai nilai nol yang mutlak.

Contoh : Jumlah peserta rapat yang hadir adalah 50 orang.

\subsection{Rangkuman}

a. Statistik maka dapat diartikan bahwa statistik adalah suatu ilmu yang digunakan untuk memecahkan suatu permasalahan dengan menggunakan beberapa tahapan yaitu pengumpulan data, pengolahan data, Analisis data dan intepretasi data serta kesimpulan dan keputusan yang diambil berdasarkan Analisis yang telah dilakukan.

b. Jenis Statistika ada dua yaitu statistik Deskriptif dan statistik inferensi

c. Elemen Dasar Statistika adalah : populasi, sampel, data, informasi, dan variabel.

d. Terdapat dua tipe data yaitu data kualitatif dan data kuantitatif. 
e. Terdapat 4 (empat) skala pengukuran, yaitu skala nominal, skala ordinal, skala interval dan skala rasio.

\subsection{Soal Latihan}

1. Jelaskan pengertian statistik dan statistika!

2. Statistika dibedakan menjadi dua, sebutkan dan berikan contohnya dalam aktivitas kehidupan seharihari!

3. Jelaskan pengertian populasi dan sampel dan berikan contohnya!

4. Jelaskan pengertian data kualitatif dan kuantitatif, sertakan contohnya!

\section{Daftar Pustaka}

Martiningtyas, Nining (2011)., Teori, Soal dan Pembahasan Statistika. Jakarta :PT.Prestasi Pustakaraya.

Santosa., R Gunawan., (2004).Statistik..Yogyakarta : Andi Spiegel, Murray R (2004)., Statistik. Jakarta:Erlangga

Sudjana, (2005). Metode Statistika. Bandung:Tarsito Wibisono, Yusuf (2009). Metode Statistik. Yogyakarta:Gadjah Mada University Press. 


\section{BAB 2 \\ PENYAJIAN DATA}

Data hasil observasi, wawancara maupun penyebaran kuesioner yang telah dikumpulkan baik dari suatu populasi maupun sampel yang digunakan dalam pengolahan data dan Analisis yang digunakan sebagai pengambilan keputusan, maka perlu diatur dan disajikan dalam bentuk yang baik, jelas dan mudah dipahami.

Terdapat dua cara penyajian data yang sering digunakan yaitu tabel atau daftar dan grafik atau diagram.

\subsection{Tabel atau Daftar}

Secara umum, skema garis besar untuk sebuah tabel terdapat beberapa bagian (Sudjana, 2005), yaitu:

1. Judul Daftar

ditulis ditengah-tengah bagian teratas, dalam beberapa baris, semuanya dengan huruf besar.

2. Judul Kolom dan judul baris ditulis dengan singkat dan jelas, bisa dalam beberapa baris dan usahakan jangan melakukan pemutusan kata.

3. Sel Daftar tempat nilai-nilai data dituliskan.

4. Catatan 
terdapat dibawah kiri sebagai catatan-catatan yang perlu diberikan atau ditambahkan.

Terdapat 3 (tiga) jenis tabel atau daftar, yaitu:

a. Daftar Baris Kolom

Pada perusahaan " $\mathrm{X}$ ", telah dilakukan transaksi pembelian barang-barang oleh unit A.

Pembelian barang-barang dalam ribuan unit dan jutaan rupiah pada tahun 2013-2015

\begin{tabular}{|c|c|c|c|c|c|c|}
\hline \multirow{2}{*}{ Barang } & \multicolumn{2}{|c|}{2013} & \multicolumn{2}{c|}{2014} & \multicolumn{2}{c|}{2015} \\
\cline { 2 - 7 } & Banyak & Harga & Banyak & Harga & Banyak & Harga \\
\hline A & 8,3 & 234,4 & 12,7 & 307,8 & 11,0 & 290,4 \\
\hline B & 10,8 & 81,4 & 9,4 & 80,5 & 13,0 & 92,0 \\
\hline Jumlah & 19,1 & 315,8 & 22,1 & 388,3 & 24,0 & 382,4 \\
\hline
\end{tabular}

Catatan : Data olahan

b. Daftar Kontingensi

Untuk data yang terdiri atas dua faktor atau dua variabel, dimana faktor yang satu terdiri atas b kategori dan lainnya terdiri atas $\mathrm{k}$ kategori, dapat dibuat daftar kontingensi berukuran bxk dengan b menyatakan baris dan k menyatakan kolom.

Banyak Murid Sekolah di Daerah A menurut Tingkat Sekolah dan Jenis Kelamin pada tahun 2013-2015 


\begin{tabular}{|c|c|c|c|c|}
\hline Tenis Kelamin & SD & SLTP & SLTA & Jumlah \\
\hline Laki-laki & 4.758 & 2.795 & 1.459 & 9.012 \\
\hline Perempuan & 4.032 & 2.116 & 1.256 & 7.404 \\
\hline Jumlah & 8,790 & 4.911 & 2.715 & 16.416 \\
\hline
\end{tabular}

\section{Catata : Data Olahan}

c. Daftar Distribusi Frekuensi

Data kuantitatif yang dapat dibuat menjadi beberapa kelompok.

Daftar Mahasiswa Universitas Muhammadiyah Sidoarjo berdasarkan Umur pada tahun 2015

\section{UMUR \\ BANYAK MAHASISWA}

\begin{tabular}{lc}
\hline $17-20$ & 1.172 \\
$21-24$ & 2.758 \\
$25-28$ & 2.976 \\
$29-32$ & 997 \\
$33-36$ & 205 \\
\hline Jumlah & 8.108 \\
\hline
\end{tabular}

\section{Catatan : Data Olahan}




\subsection{Grafik atau Diagram}

Terdapat beberapa jenis diagram, yaitu:

\section{Diagram Batang}

Data yang variabelnya berbentuk kategori atau atribut sangat tepat disajikan dalam diagram batang. Untuk menggambar diagram batang diperlukan sumbu datar dan sumbu tegak yang berpotongan tegak lurus. Kedua sumbunya dibagi menjadi beberapa skala, tetapi tidak perlu sama skalanya. Jika diagram dibuat tegak, maka sumbu datar menyatakan atribut atau waktu, sedangkan sumbu tegak menyatakan kuantum atau nilai data.

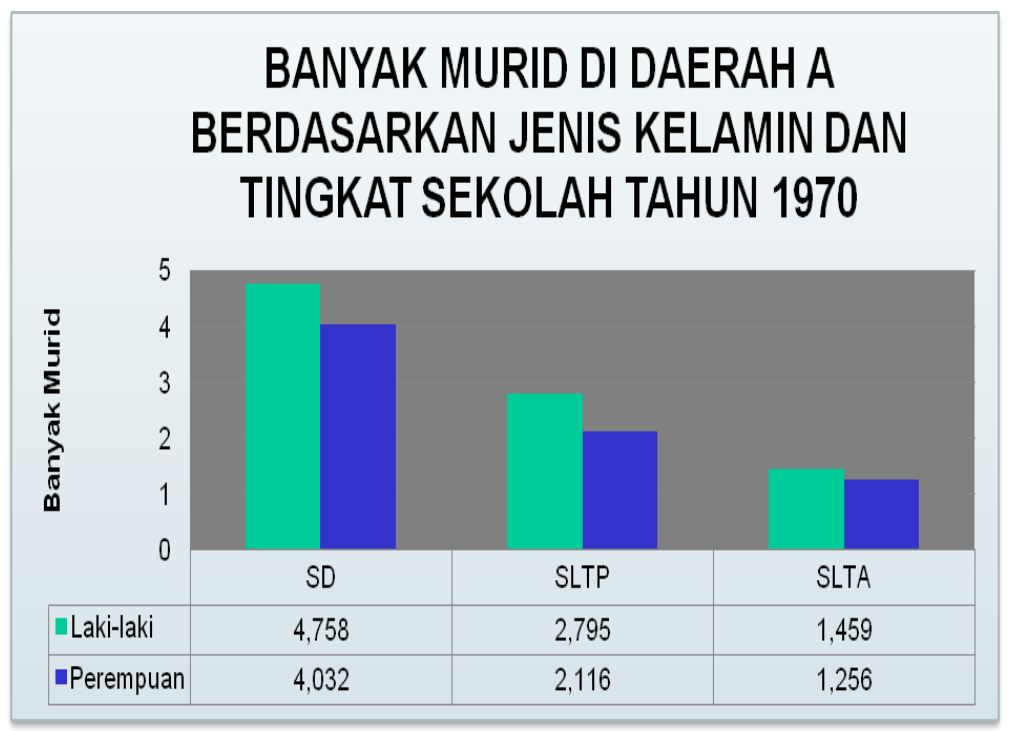




\section{Diagram Baris}

Untuk menggambarkan yang serba terus atau berkesinambungan. Diperlukan sumbu tegak dan sumbu datar yang saling tegak lurus. Sumbu datar menyatakan waktu, sedangkan sumbu tegaknya menyatakan kuantum data tiap waktu.

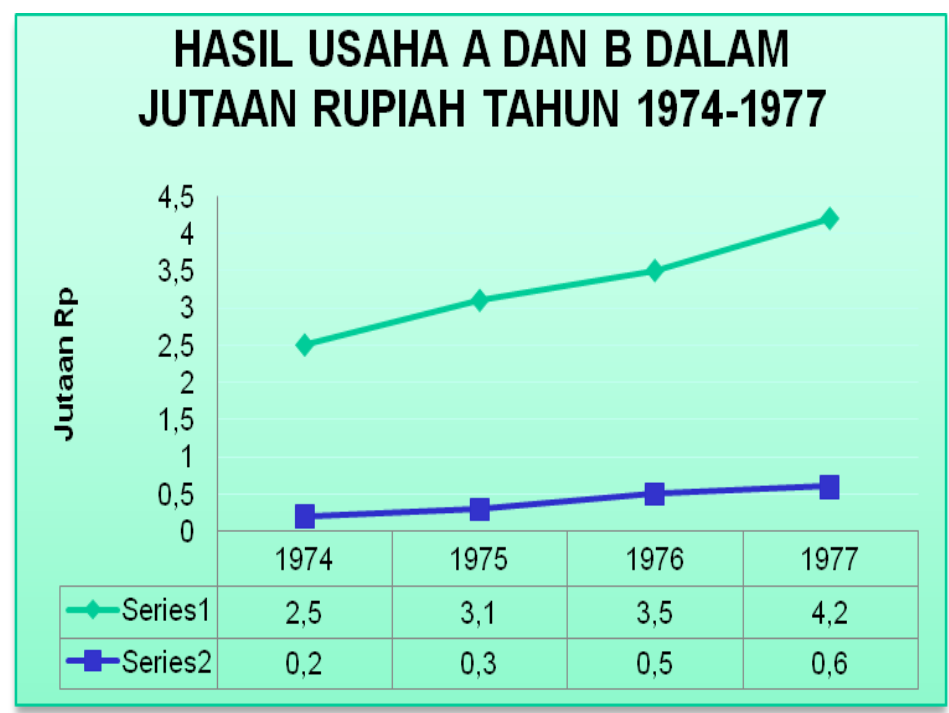

\section{Diagram Lingkaran}

Untuk membuat diagram lingkaran, gambarkan sebuah lingkaran, kemudian dibagi menjadi beberapa sektor. Tiap sektor melukiskan kategori data yang terlebih dahulu diubah kedalam derajat. Dianjurkan 
untuk pembagian mulai dari titik tertinggi lingkaran. Diagram ini digunakan untuk melukiskan data atribut.

\section{Keperluan Biaya}

\begin{tabular}{cc}
\hline Untuk & $\%$ \\
\hline Pos A & 28 \\
Pos B & 18 \\
Pos C & 14 \\
Pos D & 22 \\
Pos E & 18 \\
\hline Jumlah & 100
\end{tabular}

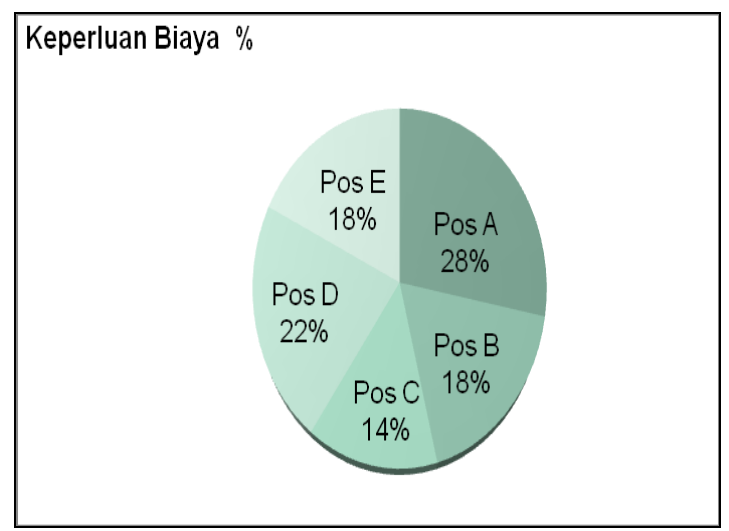

\section{Diagram Lambang}

Dipakai untuk mendapatkan gambaran kasar sesuatu hal dan sebagai alat visual bagi orang awam. 
Kesulitannya adalah menggambarkan bagian simbul untuk satuan yang tidak penuh.

Penggunaan Kendaraa Mobil di Daerah A

\begin{tabular}{|c|c|}
\hline Tahun & Jumlah \\
\hline 1987 & 1000 \\
\hline 1988 & 1250 \\
\hline 1989 & 1750 \\
\hline
\end{tabular}

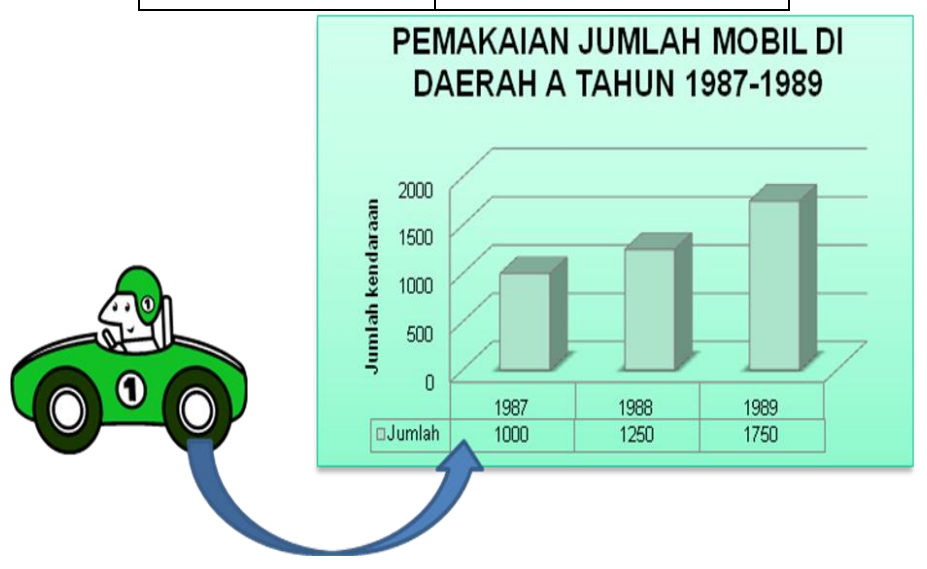

\section{Diagram Peta}

Diagram ini disebut juga kartogram. Dalam pembuatannya digunakan peta geografis tempat data terjadi. Sehingga, diagram ini melukiskan keadaan dihubungkan dengan tempat kejadiannya. Contoh : Pembagian wilayah pelayanan PLN di Surabaya. 


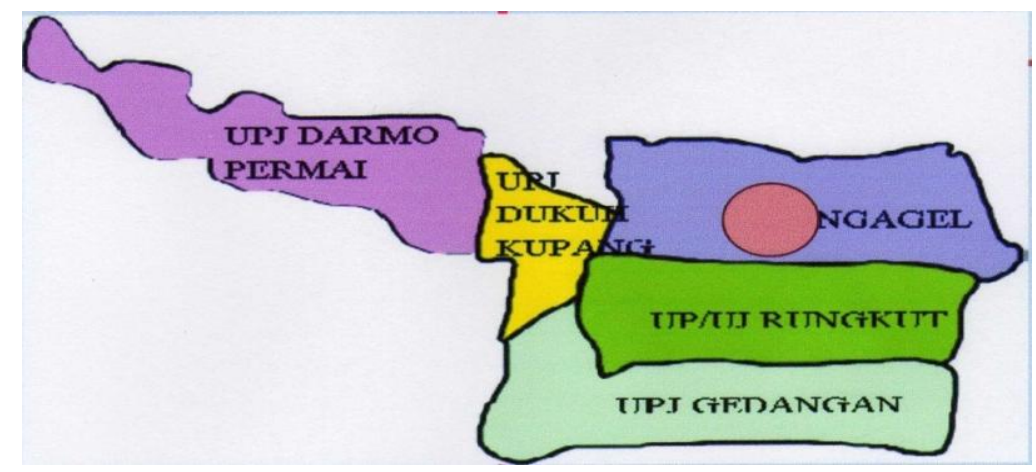

\subsection{Rangkuman}

1. Terdapat dua cara dalam menyajikan data yaitu dengan tabel atau daftar dan grafik atau diagram.

2. Terdapat 3 (tiga) jenis daftar, yaitu daftar baris dan kolom, daftar kontingensi, dan daftar frekuensi.

3. Terdapat 5 (lima) jenis diagram, yaitu diagram batang, diagran garis, diagram lingkaran, diagram lambang dan diagram peta.

\subsection{Latihan}

1.Terdapat data jumlah mahasiswa di sebuah perguruan tinggi. Diketahui bahwa 130 mahasiswa dari Fakultas Ekonomi, 150 dari Fakultas Teknik, 125 dari Fakultas Hukum, dan 126 berasal dari fakultas psikologi. Susunlah data tersebut dalam bentuk tabel dan diagram batang. 


\section{Daftar Pustaka}

Martiningtyas, Nining (2011)., Teori, Soal dan Pembahasan

Statistika., Jakarta :PT.Prestasi Pustakaraya.

Sudjana, (2005)., Metode Statistika., Bandung:Tarsito 


\section{BAB 3 \\ DISTRIBUSI FREKUENSI}

\subsection{Pendahuluan}

Tabel Frekuensi merupakan salah satu jenis penyajian data. Tabel Frekuensi adalah cara umum untuk menata atau menyusun data yang dimiliki dalam sebuah tabel yang menunjukkan sebaran atau distribusi frekuensi data dan tersusun atas frekuensi tiap-tiap kelas atau kategori yang telah ditetapkan. Frekuensi tiap kelas atau kategori menunjukkan banyaknya pengamatan dalam kelas yang sedang diamati. Untuk memperjelas uraian diatas, diberikan contoh tabel frekuensi sebagaimana ditunjukkan pada Tabel 3.1.

Tabel 3.1. Tabel Frekuensi nilai akhir matakuliah statistika dasar

\begin{tabular}{c|c}
\hline Interval (Selang) Kelas & Frekuensi $(f)$ \\
\hline $51-60$ & 5 \\
$61-70$ & 8 \\
$71-80$ & 19 \\
$81-90$ & 7 \\
\hline
\end{tabular}




\begin{tabular}{c|c}
\hline $91-100$ & 6 \\
\hline Total & 45 \\
\hline
\end{tabular}

Dengan mempelajari tabel frekuensi yang ditunjukkan dalam Tabel 3.1 paling tidak kita dapat mengetahui gambaran secara umum kemampuan mahasiswa terhadap matakuliah statistika dasar yang diberikan. Bentuk tabel frekuensi yang lain dapat ditunjukkan pada Tabel 3.2. sebagai berikut.

Tabel 3.2. Tabel Frekuensi banyaknya bola pada suatu kotak

\begin{tabular}{c|c}
\hline Kelas & Frekuensi $(f)$ \\
\hline Bola Merah & 16 \\
Bola Biru & 18 \\
Bola Hijau & 15 \\
Bola Kuning & 19 \\
Bola Ungu & 22 \\
\hline Total & 90 \\
\hline Tabel 3.2 adalah tabel frekuensi dengan kelas \\
mukan merupakan \\
menunjukkan banyaknya sesuatu yang diamati. Bila \\
dibandingkan Tabel 3.1 dan Tabel 3.2 jelas terdapat \\
perbedaan. Tabel 3.1 merupakan tabel frekuensi yang
\end{tabular}


kelasnya merupakan selang (interval) sedangkan Tabel 3.2 merupakan tabel frekuensi yang kelasnya merupakan banyaknya sesuatu.

Pembuatan tabel frekuensi dengan kelas sebagaimana ditunjukkan pada Tabel 3.2 tentu saja tidak sulit dilakukan, yaitu dengan cara menghitung berapa banyak pengamatan yang mempunyai nilai sesuai kelas yang telah ditentukan. Yang perlu dipelajari lebih lanjut adalah cara pembuatan tabel frekuensi apabila kelasnya merupakan selang sebagaimana dicontohkan pada Tabel 3.1. Pembahasan tentang tahapan-tahapan yang dilakukan dalam pembuatan tabel frekuensi yang kelasnya merupakan selang adalah sebagai berikut.

\subsection{Tahapan Pembuatan Tabel Frekuensi}

a. Penentuan banyaknya selang kelas ( $k$ )

Banyaknya selang kelas tergantung pada jumlah pengamatan dalam data yang kita miliki. Pengamatan yang tidak terlalu banyak tentunya tidak memerlukan selang kelas yang banyak, begitu pula sebaliknya pengamatan yang banyak memerlukan selang kelas yang cukup memadai untuk mencakup 
semua data pengamatan yang dimiliki. Menurut Yitnosumarto (1990), persamaan yang digunakan untuk penentuan banyaknya selang kelas dinyatakan sebagaimana persamaan 3.1. sebagai berikut.

$$
k=1+3,3 \log n
$$

di mana :

$k=$ banyaknya kelas

$n=$ jumlah data

\section{b. Penentuan selang dalam kelas (I)}

Selang dalam kelas atau lebar kelas akan tergantung pada banyaknya kelas dan kisaran data atau disebut juga dengan range. Hal penting yang perlu diperhatikan dalam penentuan selang dalam kelas adalah semua selang dalam kelas harus memiliki lebar kelas yang sama. Untuk menentukan selang dalam kelas terlebih dahulu harus mengetahui banyak kelas $(k)$ yang telah dihitung pada tahapan pertama. Menurut Yitnosumarto (1990), persamaan yang digunakan untuk penentuan selang dalam kelas dinyatakan sebagaimana persamaan 3.2 sebagai berikut. 


$$
I=\frac{R}{k}
$$

di mana :

$R=$ range atau kisaran

$k=$ banyaknya selang kelas

Range atau kisaran dapat diperoleh dari selisih antara nilai pengamatan tertinggi dengan nilai pengamatan terendah, menurut Yitnosumarto (1990), persamaan untuk menghitung kisaran dinyatakan pada persamaan 3.3 sebagai berikut.

$$
R=\mathrm{X}_{\max }-\mathrm{X}_{\min }
$$

di mana :

$\mathrm{X}_{\text {maks }}=$ nilai pengamatan tertinggi

$\mathrm{X}_{\min }=$ nilai pengamatan terendah

\section{c. Penentuan batas kelas terendah untuk kelas}

pertama

Batas kelas terendah untuk selang kelas pertama merupakan bagian penting untuk ditentukan. Pada umumnya batas kelas terendah dari selang kelas pertama ditentukan sedemikian rupa sehingga akan 
memudahkan kita untuk melihat perbedaan selang kelas pertama dengan selang kelas kedua dan seterusnya. Untuk menjelaskan hal ini akan dijelaskan uraian sebagai berikut.

Apabila kita mempunyai data antara 63 sampai dengan 97. Data tersebut merupakan hasil penilaian terhadap kemampuan dengan kisaran nilai 0 sampai dengan 100. Misalkan dengan lebar kelas 10, tentu saja akan memudahkan kita menentukan selang kelas 61-70, 71-80 dan seterusnya sampai dengan 91-100 dibandingkan dengan selang 63-72, 73-82 dan 93-102. Mengapa demikian? Hal ini karena tidak mungkin terdapat nilai 102 untuk kisaran nilai 0-100. Namun apabila semua data pada pengamatan dapat masuk dalam kisaran nilai yang ada, kita dapat langsung menggunakan nilai pengamatan terendah berdasarkan data. Catatan penting lain untuk memudahkan pembuatan tabel frekuensi adalah data yang diamati harus diurutkan terlebih dahulu.

\subsection{Frekuensi Relatif dan Frekuensi Kumulatif}

Contoh tabel frekuensi sebagaimana ditunjukkan pada Tabel 3.1 dan Tabel 3.2 dapat juga disertai dengan frekuensi relatif. Menurut Dajan (1991), frekuensi relatif dapat 
diartikan sebagai rasio antara frekuensi tiap-tiap kelas dengan frekuensi total atau banyaknya pengamatan secara keseluruhan. Frekuensi relatif dapat dinyatakan dalam bentuk proporsi terhadap frekuensi total dan dapat juga dinyatakan dalam bentuk presentase terhadap frekuensi total. Frekuensi relatif untuk Tabel 3.1 dan Tabel 3.2 dapat dinyatakan sebagaimana Tabel 3.3 dan Tabel 3.4 berikut.

Tabel 3.3. Sebaran frekuensi dan frekuensi relatif data pada Tabel 3.1

\begin{tabular}{c|c|c}
\hline $\begin{array}{c}\text { Interval (Selang) } \\
\text { Kelas }\end{array}$ & Frekuensi $(f)$ & Frekuensi Relatif \\
\hline $51-60$ & 5 & $5 / 45=0,11$ \\
$61-70$ & 8 & $8 / 45=0,18$ \\
$71-80$ & 19 & $19 / 45=0,42$ \\
$81-90$ & 7 & $7 / 45=0,16$ \\
$91-100$ & 6 & $6 / 45=0,13$ \\
\hline Total & 45 & $45 / 45=1$ \\
\hline
\end{tabular}

Tabel 3.4. Sebaran frekuensi dan frekuensi relatif data pada Tabel 3.2 


\begin{tabular}{c|c|c}
\hline Bola Merah & 16 & $16 / 90=0,18$ \\
Bola Biru & 18 & $18 / 90=0,2$ \\
Bola Hijau & 15 & $15 / 90=0,17$ \\
Bola Kuning & 19 & $19 / 90=0,21$ \\
Bola Ungu & 22 & $22 / 90=0,24$ \\
\hline Total & 90 & $90 / 90=1$ \\
\hline
\end{tabular}

Apabila frekuensi relatif pada Tabel 3.3 dan tabel 3.4 diatas dinyatakan dalam persentase maka akan diperoleh frekuensi relatif berturut-turut untuk Tabel 3.3 adalah 11\%, $18 \%, 42 \%, 16 \%$ dan $13 \%$ sedangkan frekuensi relatif berturut-turut untuk Tabel 3.4 adalah 18\%, 20\%, 17\%, 21\% dan $24 \%$.

Selain frekuensi relatif, dalam penyajian data pada tabel frekuensi juga dikenal istilah frekuensi kumulatif. Frekuensi kumulatif didapatkan dengan menjumlahkan frekuensi demi frekuensi pada setiap kelas. Frekuensi kumulatif untuk Tabel 3.1 dan Tabel 3.2 dapat dinyatakan sebagaimana Tabel 3.3 dan Tabel 3.4 berikut.

Tabel 3.5. Sebaran frekuensi dan frekuensi relatif data pada Tabel 3.1 


\begin{tabular}{c|c|c}
\hline $\begin{array}{c}\text { Interval (Selang) } \\
\text { Kelas }\end{array}$ & Frekuensi $(f)$ & $\begin{array}{c}\text { Frekuensi } \\
\text { Kumulatif }\end{array}$ \\
\hline $51-60$ & 5 & 5 \\
$61-70$ & 8 & 13 \\
$71-80$ & 19 & 32 \\
$81-90$ & 7 & 39 \\
$91-100$ & 6 & 45 \\
\hline Total & 45 & \\
\hline
\end{tabular}

Tabel 3.6. Sebaran frekuensi dan frekuensi relatif data pada Tabel 3.2

\begin{tabular}{c|c|c}
\hline Kelas & Frekuensi $(f)$ & $\begin{array}{c}\text { Frekuensi } \\
\text { kumulatif }\end{array}$ \\
\hline Bola Merah & 16 & 16 \\
Bola Biru & 18 & 34 \\
Bola Hijau & 15 & 49 \\
Bola Kuning & 19 & 68 \\
Bola Ungu & 22 & 90 \\
\hline Total & 90 & \\
\hline
\end{tabular}




\section{$\underline{3.4 \text { Contoh Soal }}$}

Untuk lebih memahami tentang uraian materi tabel frekuensi yang telah dijelaskan berikut ini diberikan contoh kasus pembuatan tabel frekuensi dengan kelas merupakan selang (interval).

1. Berikut ini adalah data siswa yang hadir untuk mengikuti bimbingan belajar pada 20 hari terakhir di suatu Lembaga Bimbingan Belajar. Data siswa tersebut disajikan lengkap pada Tabel 3.7 di bawah ini :

Tabel 3.7. Data siswa yang hadir pada 20 hari terakhir di suatu LBB

\begin{tabular}{|c|c|c|c|c|c|c|c|c|c|}
\hline 6 & 7 & 9 & 12 & 14 & 15 & 18 & 20 & 21 & 21 \\
\hline 23 & 25 & 27 & 31 & 31 & 31 & 31 & 33 & 34 & 35 \\
\hline
\end{tabular}

Buatlah tabel frekuensi, frekuensi relatif dan frekuensi kumulatif berdasarkan data yang tersedia!

Sesuai dengan uraian yang telah dijelaskan terdapat tiga tahapan dalam pembuatan tabel frekuensi, yaitu :
a. Penentuan banyaknya selang kelas $(k)$
b. Penentuan selang dalam kelas (I)
c. Penentuan batas kelas terendah untuk kelas pertama 
Berdasarkan tiga tahapan pembuatan tabel frekuensi diatas maka akan kita buat tabel frekuensi dengan contoh kasus yang ada.

\section{a. Penentuan banyaknya selang kelas $(k)$}

Penentuan banyaknya selang kelas dihitung berdasarkan persamaan (3.1) yaitu sebagai berikut :

$$
k=1+3,3 \log n
$$

di mana :

$k=$ banyaknya kelas

$n=$ jumlah data

Berdasarkan data yang ada diketahui bahwa jumlah unit data yang diamati adalah 20 hari, sehingga pada contoh kasus ini $n$ (jumlah data) adalah 20. Selanjutnya akan dihitung banyaknya selang kelas berdasarkan data siswa yang hadir pada 20 hari terakhir di suatu LBB menggunakan persamaan di atas sehingga diperoleh hasil sebagai berikut :

$$
\begin{aligned}
k & =1+3,3 \log n \\
& =1+3,3 \log (20)=5,2 \approx 5
\end{aligned}
$$




\section{b. Penentuan selang dalam kelas (I)}

Penentuan selang dalam kelas dihitung berdasarkan persamaan 3.2. yaitu sebagai berikut :

$$
I=\frac{R}{k}
$$

di mana :

$R=\mathrm{X}_{\text {maks }}-\mathrm{X}_{\min }$

$k=$ banyaknya selang kelas

Untuk menghitung selang dalam kelas terlebih dahulu kita harus mengetahui range atau kisaran dari data yang kita miliki. Berdasarkan persamaan di atas, range atau kisaran diperoleh dengan menghitung selisih nilai pengamatan tertingi dengan nilai pengamatan terendah. Nilai pengamatan tertinggi $\left(\mathrm{X}_{\text {maks }}\right)$ pada data adalah 35 sedangkan nilai pengamatan terendah $\left(\mathrm{X}_{\min }\right)$ pada data adalah 6 . Sehingga range atau kisaran data adalah $R=\mathrm{X}_{\text {maks }}-\mathrm{X}_{\min }=35-6=29$. Selanjutnya akan dihitung selang(interval) dalam kelas pada data siswa yang hadir pada 20 hari terakhir di suatu LBB menggunakan persamaan di atas sehingga diperoleh hasil sebagai berikut :

$$
\begin{aligned}
I & =\frac{R}{k} \\
& =\frac{29}{5}=5,8 \approx 6
\end{aligned}
$$




\section{c. Penentuan batas kelas terendah untuk kelas pertama}

Penentuan batas kelas terendah untuk kelas pertama dapat langsung menggunakan nilai pengamatan terendah pada data, hal ini dikarenakan semua data pada pengamatan dapat masuk dalam kisaran nilai yang ada.

Setelah melakukan perhitungan pada tiga tahapan dalam pembuatan tabel frekuensi dihasilkan tabel frekuensi untuk data siswa yang hadir pada 20 hari terakhir di suatu LBB sebagaimana Tabel 3.8. sebagai berikut :

Tabel 3.8. Tabel frekuensi siswa yang hadir pada 20 hari terakhir di suatu LBB

\begin{tabular}{c|c}
\hline $\begin{array}{c}\text { Selang } \\
\text { (Interval) Kelas }\end{array}$ & Frekuensi $(f)$ \\
\hline $6-11$ & 3 \\
\hline $12-17$ & 3 \\
\hline $18-23$ & 5 \\
\hline $24-29$ & 2 \\
\hline $30-35$ & 7 \\
\hline Total & 20 \\
\hline
\end{tabular}


Selanjutnya setelah terbentuk tabel frekuensi data, akan kita hitung juga frekuensi relatif dan frekuensi kumulatif data berdasarkan tabel frekuensi yang telah dibuat dan selengkapnya disajikan pada tabel 3.9 sebagai berikut.

Tabel 3.8. Tabel frekuensi siswa yang hadir pada 20 hari terakhir di suatu LBB

\begin{tabular}{|c|c|c|c|}
\hline $\begin{array}{c}\text { Selang } \\
\text { (Interval) } \\
\text { Kelas }\end{array}$ & $\begin{array}{c}\text { Frekuensi } \\
(f)\end{array}$ & Frekuensi Relatif & $\begin{array}{l}\text { Frekuensi } \\
\text { Kumulatif }\end{array}$ \\
\hline $6-11$ & 3 & $\begin{array}{l}3 / 20=0,15 \\
(15 \%)\end{array}$ & 3 \\
\hline $12-17$ & 3 & $\begin{array}{l}3 / 20=0,15 \\
(15 \%)\end{array}$ & 6 \\
\hline $18-23$ & 5 & $\begin{array}{l}5 / 20=0,25 \\
(25 \%)\end{array}$ & 11 \\
\hline $24-29$ & 2 & $\begin{array}{l}2 / 20=0,1 \\
(10 \%)\end{array}$ & 13 \\
\hline $30-35$ & 7 & $\begin{array}{l}7 / 20=0,35 \\
(35 \%)\end{array}$ & 20 \\
\hline Total & 2 & $\begin{array}{l}20 / 20=1 \\
(100 \%)\end{array}$ & \\
\hline
\end{tabular}




\subsection{Rangkuman}

- Tabel Frekuensi adalah cara umum untuk menata atau menyusun data yang dimiliki dalam sebuah tabel yang menunjukkan sebaran atau distribusi frekuensi data.

- Terdapat tiga tahapan dalam pembuatan tabel frekuensi, yaitu sebagai berikut:

a. Penentuan banyaknya selang kelas $(k)$

$$
k=1+3,3 \log n
$$

di mana :

$k=$ banyaknya kelas

$n=$ jumlah data

b. Penentuan selang dalam kelas $(I)$

$$
I=\frac{R}{k}
$$

di mana :

$R=$ range $/$ kisaran

$k=$ banyaknya selang kelas 
Range atau kisaran dapat diperoleh dari selisih antara nilai pengamatan tertinggi dengan nilai pengamatan terendah

$$
R=\mathrm{X}_{\text {max }}-\mathrm{X}_{\text {min }}
$$

di mana :

$\mathrm{X}_{\text {maks }}=$ nilai pengamatan tertinggi

$\mathrm{X}_{\min }=$ nilai pengamatan terendah

c. Penentuan batas kelas terendah untuk kelas pertama

Batas kelas terendah untuk selang kelas pertama dapat langsung menggunakan nilai pengamatan terendah berdasarkan data apabila semua data dapat masuk dalam kisaran nilai yang ada

- Frekuensi relatif dapat adalah rasio antara frekuensi tiap-tiap kelas dengan frekuensi total atau banyaknya pengamatan secara keseluruhan sedangkan frekuensi kumulatif didapatkan dengan menjumlahkan frekuensi demi frekuensi pada setiap kelas.

\subsection{Latihan}

1. Buatlah tabel frekuensi, frekuensi relatif dan frekuensi kumulatif berdasarkan data nilai UAS 30 mahasiswa pada matakuliah dasar-dasar pemrograman sebagai berikut : 


\begin{tabular}{|c|c|c|c|c|c|c|c|c|c|}
\hline 75 & 73 & 69 & 63 & 85 & 60 & 67 & 76 & 78 & 89 \\
\hline 91 & 74 & 77 & 73 & 78 & 77 & 69 & 84 & 64 & 79 \\
\hline 75 & 72 & 71 & 67 & 66 & 81 & 87 & 75 & 76 & 78 \\
\hline
\end{tabular}

2. Berikut ini merupakan tabel frekuensi jumlah siswa kelas 1 sampai dengan kelas 6 pada sebuah Sekolah Dasar :

\begin{tabular}{c|l}
\hline Kelas & \multicolumn{1}{|c}{$\begin{array}{c}\text { Frekuensi } \\
(f)\end{array}$} \\
\hline Kelas 1 & 34 \\
\hline Kelas 2 & 35 \\
\hline Kelas 3 & 29 \\
\hline Kelas 4 & 30 \\
\hline Kelas 5 & 33 \\
\hline Kelas 6 & 39 \\
\hline Total & 200 \\
\hline
\end{tabular}

Buatlah tabel frekuensi relatif dan frekuensi kumulatif berdasarkan tabel frekuensi di atas ! 
3. Lakukan pengumpulan data dikelas, catat berat badan dan tinggi badan masing-masing mahasiswa. Selanjutnya buatlah tabel frekuensi, frekuensi relatif dan frekuensi kumulatif untuk data berat badan dan tinggi badan mahasiswa.

\section{Daftar Pustaka}

Dajan, Anto. (1991). Pengantar Metode Statistik. Jakarta: PT. Pustaka LP3ES.

Yitnosumarto, Suntoyo. (1990). Dasar-Dasar Statistika. Jakarta: Rajawali Pers. 
Halaman ini sengaja dikosongkan 


\section{UKURAN DAN PEMUSATAN DAN \\ PENYIMPANGAN DATA}

\subsection{Pendahuluan}

Ukuran pemusatan atau disebut dengan tendensi sentral adalah penjabaran data yang berulang atau berpusat pada nilai-nilai tertentu secara kuantitatif . Ukuran pemusatan adalah cara untuk mencari nilai tengah dari satu gugus data, yang telah diurutkan dari nilai yang terkecil sampai yang terbesar atau sebaliknya dari nilai terbesar sampai yang terkecil. Sedangkan ukuran penyimpangan data atau disebut juga ukuran dispersi adalah ukuran yang menyatakan seberapa jauh penyimpangan nilai-nilai data dari nilai pusatnya. Ukuran pemusatan dan penyimpangan data dibagi atas dua jenis, yaitu ukuran pemusatan dan penyimpangan data untuk data yang tidak dikelompokkan serta ukuran pemusatan dan penyimpangan data untuk data yang dikelompokkan. Data yang dikelompokkan adalah data yang sudah disajikan dalam tabel frekuensi seperti yang telah dibahas pada materi sebelumnya. Berikut ini adalah beberapa jenis ukuran pemusatan dan penyimpangan data. 
Terdapat beberapa jenis ukuran pemusatan data adalah sebagai berikut :

1. Rata-rata (mean)

2. Median

3. Modus

4. Kuartil

5. Desil

6. Persentil

Terdapat beberapa ukuran penyimpangan data, yaitu:

1. Range atau kisaran

2. Ragam atau variance

3. Simpangan baku atau standart deviasi

Berikut ini akan diuraikan satu persatu ukuran pemusatan dan penyimpangan data baik untuk data yang tidak dikelompokkan dan data yang dikelompokkan.

\subsection{Jenis- jenis Ukuran Pemusatan Data}

Seperti yang telah disebutkan dibagian awal terdapat enam jenis ukuran pemusatan data yaitu rata-rata (mean), median, modus, kuartil, desil dan persentil. Berikut akan diuraikan lebih jelas tentang beberapa ukuran pemusatan tersebut baik untuk data yang tidak dikelompokkan dan data yang dikelompokkan. 


\subsubsection{Rata-rata (mean)}

Rata-rata (mean) dapat didefinisikan sebagai jumlah seluruh nilai data dibagi dengan jumlah data yang digunakan. Menurut Supranto (2008), persamaan untuk menghitung nilai rata-rata data yang tidak dikelompokkan dan data yang dikelompokkan secara berurutan dinyatakan sebagaimana persamaan 4.1 dan 4.2 sebagai berikut.

1. Data tidak dikelompokkan

$$
\bar{x}=\frac{\sum_{i=1}^{n} X_{i}}{n}
$$

di mana :

$$
\begin{aligned}
& i=1,2,3, \ldots, n \\
& n=\text { banyaknya data }
\end{aligned}
$$

2. Data dikelompokkan

$$
\bar{x}=\frac{\sum_{i=1}^{k} f_{i} X_{i}}{\sum_{i=1}^{k} f_{i}}
$$


di mana :

$$
\begin{aligned}
& i=1,2,3, \ldots, k \\
& k=\text { banyaknya kelas }
\end{aligned}
$$

\subsubsection{Median}

Median dapat didefinisikan sebagai nilai tengah yang memisahkan data yang tinggi dan data yang rendah. Menurut Supranto (2008), persamaan untuk menghitung median data yang tidak dikelompokkan dan data yang dikelompokkan secara berurutan dinyatakan sebagaimana persamaan 4.3 dan 4.4 sebagai berikut.

1. Data tidak dikelompokkan

$$
\begin{aligned}
& \text { untuk n ganjil } \rightarrow \mathrm{Me}=X_{(n+1) / 2} \\
& \text { untuk n genap } \rightarrow \mathrm{Me}=\frac{X_{(n / 2)}+X_{(n / 2+1)}}{2}
\end{aligned}
$$


di mana :

$$
\begin{aligned}
& i=1,2,3, \ldots, n \\
& n=\text { banyaknya data }
\end{aligned}
$$

2. Data dikelompokkan

$$
M e=B b+\frac{\left(0,5 f_{t}-f_{s m}\right)}{f_{m}} I
$$

di mana :

$\mathrm{Bb}=$ batas kelas terendah, dimana terletak median yaitu pada frekuensi kumulatif ke- $\left(\frac{1}{2} n\right)$

$f_{t}=$ frekuensi total

$f_{s m}=$ total frekuensi sebelum median

$f_{m}=$ frekuensi pada kelas yang mengandung median

I = Interval kelas

\subsubsection{Modus}

Modus dapat didefinisikan sebagai nilai yang paling sering muncul. Untuk menghitung nilai modus pada data tidak dikelompokkan tidak sulit yaitu dengan menghitung secara manual berapa banyak nilai pengamatan yang paling sering muncul, sedangkan untuk menghitung nilai modus 
pada data tidak dikelompokkan menurut Supranto (2008), dinyatakan sebagaimana persamaan 4.5 sebagai berikut.

1. Data dikelompokkan

$$
M o=B b+\left(\frac{a}{a+b}\right) I
$$

di mana :

$B b=$ batas bawah kelas dengan frekuensi tertinggi

$a=$ selisih frekuensi tertinggi dengan frekuensi kelas sebelumnya

$\mathrm{b}=$ selisih frekuensi tertinggi dengan frekuensi kelas sesudahnya

$I=$ interval kelas

\subsubsection{Kuartil, Desil dan Persentil}

\subsubsection{Kuartil}

Kuartil atau disebut perempatan, desil atau disebut persepuluhan dan persentil atau disebut perseratusan juga merupakan besaran yang digunakan untuk ukuran pemusatan data. Kuartil, desil dan persentil dapat dihitung untuk data yang dikelompokkan. Menurut Yitnosumarto (2010), 
persamaan untuk menghitung kuartil, desil dan persentil secara berurutan dinyatakan sebagaimana persamaan 4.6, 4.7 dan 4.8 sebagai berikut :

$$
K p=B b+\left(\frac{\frac{p}{4} f_{t}-f_{s p}}{f_{p}}\right) I
$$

di mana : $\quad p=1,2$ atau 3 (yaitu perempatan ke-1, ke-2 atau ke-3)

$B b=$ batas bawah kelas terendah pada kelas dimana terl

$f_{t}=$ frekuensi total

$f_{s p}=$ frekuensi kelas sebelum kelas kuartil

$f_{p}=$ frekuensi kelas dimana terletak kuartil ke-p

$I=$ interval kelas

\subsubsection{Desil}

$$
D p=B b+\left(\frac{\frac{p}{10} f_{t}-f_{s p}}{f_{p}}\right) I
$$

di mana :

$p=1,2,3, \ldots, 10$

$B b=$ batas bawah kelas terendah pada kelas dimana terletak desil ke-p

$f_{t}=$ frekuensi total

$f_{s p}=$ frekuensi kelas sebelum kelas desil

$f_{p}=$ frekuensi kelas dimana terletak desil ke-p

$I$ = interval kelas 


\subsubsection{Persentil}

$$
P p=B b+\left(\frac{\frac{p}{100} f_{t}-f_{s p}}{f_{p}}\right) I
$$

di mana :

$p=1,2,3, \ldots, 100$

$B b=$ batas bawah kelas terendah pada kelas dimana terletak persentil ke-p

$f_{t}=$ frekuensi total

$f_{s p}=$ frekuensi kelas sebelum kelas persentil

$f_{p}=$ frekuensi kelas dimana terletak persentil ke-p

$I$ = interval kelas

\subsection{Jenis-jenis Ukuran Penyimpangan Data}

\subsubsection{Range}

Range atau kisaran data dapat didefinisikan sebagai interval yang memuat semua data. Range baik untuk data yang tidak dikelompokkan atau data yang dikelompokkan sangat mudah untuk dihitung yaitu dengan menghitung selisih antara nilai pengamatan tertinggi dengan nilai pengamatan terendah. Menurut walpole (1995), persamaan untuk menghitung range 
(kisaran) dinyatakan sebagaimana persamaan 4.9 sebagai berikut:

$$
R=\mathrm{X}_{\text {max }}-\mathrm{X}_{\text {min }}
$$

di mana :

$$
\begin{aligned}
& X_{\text {maks }}=\text { nilai pengamatan tertinggi } \\
& X_{\text {min }}=\text { nilai pengamatan terendah }
\end{aligned}
$$

\subsection{2 . Ragam atau Variance dan Simpangan Baku atau Standart Deviasi}

Ragam atau Variance dapat didefinisikan sebagai nilai yang menunjukkan seberapa jauh data menyimpang dari rataratanya. Persamaan untuk menghitung ragam (variance) data yang tidak dikelompokkan dan data yang dikelompokkan menurut walpole (1995), secara berurutan dinyatakan sebagaimana persamaan 4.10 dan 4.11 sebagai berikut.

1. Data tidak dikelompokkan

$$
s^{2}=\frac{\left(\sum_{i=1}^{n} X_{i}^{2}-\left(\sum_{i=1}^{n} X_{i}\right)^{2} / n\right)}{n-1}
$$


di mana :

$$
\begin{aligned}
& i=1,2,3, \ldots, n \\
& n=\text { banyaknya data }
\end{aligned}
$$

\section{Data dikelompokkan}

$$
s^{2}=\frac{\left(\sum_{i=1}^{k} f_{i} X_{i}^{2}-\left(\sum_{i=1}^{k} f_{i} X_{i}\right)^{2} / \sum_{i=1}^{k} f_{i}\right)}{n-1}
$$

di mana :

$$
\begin{aligned}
& f_{i}=\text { frekuensi setiap kelas } \\
& X_{i}=\text { nilai tengah kelas } \\
& i \quad=1,2,3, \ldots, n \\
& n=\text { banyaknya data }
\end{aligned}
$$

Simpangan baku atau standart deviasi adalah akar dari ragam (variance). Sehingga untuk menghitung nilai sangat mudah yaitu dengan mengakarkan nilai ragam (variance).

\subsection{Contoh Soal}

Untuk lebih memahami tentang uraian materi ukuran pemusatan dan penyimpangan data yang telah dijelaskan berikut ini diberikan contoh kasus ukuran pemusatan dan penyebaran data. Contoh kasus yang digunakan sama dengan 
contoh kasus pada pembuatan tabel frekuensi yaitu data siswa yang hadir untuk mengikuti bimbingan belajar pada 20 hari terakhir di suatu Lembaga Bimbingan Belajar. Data siswa tersebut disajikan lengkap pada Tabel 4.1 di bawah ini :

Tabel 4.1 Data siswa yang hadir pada 20 hari terakhir di suatu LBB

\begin{tabular}{|c|c|c|c|c|c|c|c|c|c|}
\hline 6 & 7 & 9 & 12 & 14 & 15 & 18 & 20 & 21 & 21 \\
\hline 23 & 25 & 27 & 31 & 31 & 31 & 31 & 33 & 34 & 35 \\
\hline
\end{tabular}

Sesuai dengan uraian yang telah dijelaskan terdapat enam ukuran pemusatan data yaitu rata-rata, median, modus, kuartil, desil dan persentil sedangkan untuk ukuran penyimpangan data terdapat tiga jenis yaitu range, ragam atau variance dan simpangan baku atau standart deviasi. Sebagai contoh berikut ini akan dihitung ukuran pemusatan dan penyimpangan data baik untuk data dikelompokkan dan data tidak dikelompokkan. 


\section{$\underline{\text { Data tidak dikelompokkan }}$}

a. Ukuran pemusatan data

1. Rata-rata

Persamaan untuk menghitung nilai rata-rata data yang tidak dikelompokkan dan dinyatakan sebagaimana persamaan 4.1 yaitu sebagai berikut :

$$
\bar{x}=\frac{\sum_{i=1}^{n} X_{i}}{n}
$$

Berdasarkan data yang ada diketahui bahwa :

$$
\begin{aligned}
& n=20 \\
& \sum_{i=1}^{n} X_{i}=444
\end{aligned}
$$

sehingga diperoleh nilai rata-rata adalah sebagai berikut :

$$
\bar{x}=\frac{\sum_{i=1}^{n} X_{i}}{n}=\frac{444}{20}=22,2 \approx 22
$$




\section{Median}

Persamaan untuk menghitung median data yang tidak dikelompokkan dinyatakan sebagaimana persamaan 4.2 yaitu sebagai berikut :

$$
\begin{aligned}
& \text { untuk n ganjil } \rightarrow \mathrm{Me}=X_{(n+1) / 2} \\
& \text { untuk n genap } \rightarrow \mathrm{Me}=\frac{X_{(n / 2)}+X_{(n / 2+1)}}{2}
\end{aligned}
$$

Berdasarkan data yang ada diketahui bahwa jumlah data $(n)$ adalah genap sehingga untuk menghitung median digunakan persamaan yang kedua.

$$
\begin{aligned}
\mathrm{Me} & =\frac{X_{(n / 2)}+X_{(n / 2+1)}}{2} \\
& =\frac{X_{(10)}+X_{(11)}}{2}=\frac{21+23}{2}=22
\end{aligned}
$$

2. Modus

Menghitung nilai modus pada data tidak dikelompokkan tidak sulit yaitu dengan menghitung secara manual berapa banyak nilai pengamatan yang paling sering muncul. Nilai yang paling sering muncul pada data siswa yang hadir untuk mengikuti bimbingan belajar pada 20 hari 
terakhir di suatu Lembaga Bimbingan Belajar adalah 31, sehingga modus untuk data tersebut adalah 31

b. Ukuran penyimpangan data

1. Range atau Kisaran

Persamaan untuk menghitung range (kisaran) dinyatakan sebagaimana persamaan 4.9 yaitu sebagai berikut:

$$
R=\mathrm{X}_{\text {max }}-\mathrm{X}_{\text {min }}
$$

di mana :

$\mathrm{X}_{\mathrm{maks}}=$ nilai pengamatan tertinggi

$\mathrm{X}_{\min }=$ nilai pengamatan terendah

Berdasarkan data yang ada diketahui bahwa :

$\mathrm{X}_{\mathrm{maks}}=35$

$X_{\min }=6$

Sehingga nilai range atau kisaran data adalah

$$
\begin{aligned}
R & =\mathrm{X}_{\text {max }}-\mathrm{X}_{\min } \\
& =35-6=29
\end{aligned}
$$


2. Ragam atau variance dan simpangan baku atau standart deviasi

Persamaan untuk menghitung ragam (variance) dinyatakan sebagaimana persamaan 4.10 yaitu sebagai berikut:

$$
s^{2}=\frac{\left(\sum_{i=1}^{n} X_{i}^{2}-\left(\sum_{i=1}^{n} X_{i}\right)^{2} / n\right)}{n-1}
$$

Berdasarkan data yang ada diketahui bahwa

$$
\begin{aligned}
& \sum_{i=1}^{n} X_{i}=444 \\
& \sum_{i=1}^{n} X_{i}^{2}=11534 \\
& n=20
\end{aligned}
$$

Sehingga nilai ragam (variance) adalah

$$
s^{2}=\frac{\sum_{i=1}^{n} X_{i}^{2}-\left(\left(\sum_{i=1}^{n} X_{i}\right)^{2} / n\right)}{n-1}=\frac{11534-\left((444)^{2} / 20\right)}{19}=88,27
$$

Simpangan baku atau standart deviasi adalah akar dari ragam (variance). Sehingga simpangan baku untuk data tersebut adalah

$$
s=\sqrt{\frac{\sum_{i=1}^{n} X_{i}^{2}-\left(\left(\sum_{i=1}^{n} X_{i}\right)^{2} / n\right)}{n-1}}=\sqrt{\frac{11534-\left((444)^{2} / 20\right)}{19}}=9,4
$$




\section{Data dikelompokkan}

Data dikelompokkan adalah data yang sudah disajikan dalam tabel frekuensi, sehinnga untuk menghitung ukuran pemusatan dan penyimpangan data dikelompokkan terlebih dahulu harus membentuk tabel frekuensi. Karena contoh kasus yang digunakan sama dengan conoh kasus pada pembahasan tabel frekuensi, sehingga kita dapat langsung menggunakan tabel frekuensi yang telah terbentuk dengan menambahkan beberapa komponen lain untuk menghitung ukuran pemusatan dan ukuran penyimpangan data yang dikelompokkan. Tabel frekuensi besaerta komponen lain untuk data siswa yang hadir untuk mengikuti bimbingan belajar pada 20 hari terakhir di suatu Lembaga Bimbingan Belajar adalah sebagai berikut :

\begin{tabular}{|c|c|c|c|c|c|c|}
\hline $\begin{array}{c}\text { Inter } \\
\text { val }\end{array}$ & $\begin{array}{c}\text { Frekuen } \\
\text { si }(f i)\end{array}$ & $\begin{array}{c}\text { Frekue } \\
\text { nsi } \\
\text { Kumul } \\
\text { atif }\end{array}$ & $\begin{array}{c}\text { Nilai Tengah } \\
(X i)\end{array}$ & $X i^{2}$ & $f i X i$ & $f i X i^{2}$ \\
\hline $6-11$ & 3 & 3 & 8,5 & & 25, & 216, \\
& & & & 72,25 & 5 \\
\hline
\end{tabular}




\begin{tabular}{|c|c|c|c|c|c|c|}
\hline $\begin{array}{c}12- \\
17\end{array}$ & 3 & 6 & 14,5 & 210,2 & 43, & 630, \\
5 & 5 & 75 \\
\hline $18-$ & 5 & 11 & 20,5 & 420,2 & 10 & 210 \\
23 & & & & 5 & 2,5 & 1,3 \\
\hline $24-$ & 2 & 15 & 26,5 & 702,2 & & 140 \\
29 & & & & 5 & 53 & 4,5 \\
\hline $30-$ & 7 & 20 & 32,5 & 1056, & 22 & 739 \\
35 & & & & 25 & 7,5 & 3,8 \\
\hline Juml & 20 & & & & 452 & 117 \\
ah & & & & & & 47 \\
\hline
\end{tabular}

\section{a. Ukuran pemusatan data}

\section{Rata-rata}

Persamaan untuk menghitung nilai rata-rata data yang tidak dikelompokkan dan dinyatakan sebagaimana persamaan 4.2 yaitu sebagai berikut :

$$
\bar{x}=\frac{\sum_{i=1}^{k} f_{i} X_{i}}{\sum_{i=1}^{k} f_{i}}
$$


Berdasarkan tabel frekuensi yang terbentuk diketahui bahwa :

$$
\begin{aligned}
& \sum_{i=1}^{k} f_{i} X_{i}=452 \\
& \sum_{i=1}^{k} f_{i}=20
\end{aligned}
$$

sehingga diperoleh nilai rata-rata adalah sebagai berikut :

$$
\bar{x}=\frac{\sum_{i=1}^{k} f_{i} X_{i}}{\sum_{i=1}^{k} f_{i}}=\frac{452}{20}=22,6 \approx 23
$$

2. Median

Persamaan untuk menghitung median data dikelompokkan dinyatakan sebagaimana persamaan 4.4 yaitu sebagai berikut

$$
M e=B b+\frac{\left(0,5 f_{t}-f_{s m}\right)}{f_{m}} I
$$

Berdasarkan tabel frekuensi yang terbentuk diketahui bahwa : 


\begin{tabular}{|c|c|c|c|c|c|c|}
\hline $\begin{array}{l}\text { Inter } \\
\text { val }\end{array}$ & $\begin{array}{c}\text { Frekuen } \\
\text { si }(f i)\end{array}$ & $\begin{array}{c}\text { Frekue } \\
\text { nsi } \\
\text { Kumul } \\
\text { atif }\end{array}$ & $\begin{array}{l}\text { Nilai Tengah } \\
\qquad(X i)\end{array}$ & $X i^{2}$ & $f i X i$ & $f i X i^{2}$ \\
\hline $6-11$ & 3 & 3 & 8,5 & 72,25 & $\begin{array}{c}25 \\
5\end{array}$ & $\begin{array}{c}216 \\
75\end{array}$ \\
\hline $\begin{array}{l}12- \\
17\end{array}$ & 3 & 6 & 14,5 & $\begin{array}{c}210,2 \\
5\end{array}$ & $\begin{array}{c}43 \\
5\end{array}$ & $\begin{array}{c}630, \\
75\end{array}$ \\
\hline $\begin{array}{l}18- \\
23\end{array}$ & $\overline{5}$ & 11 & 20,5 & $\begin{array}{c}420,2 \\
5\end{array}$ & $\begin{array}{l}10 \\
2,5\end{array}$ & $\begin{array}{l}210 \\
1,3\end{array}$ \\
\hline $\begin{array}{l}24- \\
29\end{array}$ & 2 & 15 & 26,5 & $\begin{array}{c}702,2 \\
5\end{array}$ & 53 & $\begin{array}{l}140 \\
4,5\end{array}$ \\
\hline $\begin{array}{l}30- \\
35\end{array}$ & 7 & 20 & 32,5 & $\begin{array}{c}1056 \\
25\end{array}$ & $\begin{array}{l}22 \\
7,5\end{array}$ & $\begin{array}{l}739 \\
3,8\end{array}$ \\
\hline $\begin{array}{c}\text { Juml } \\
\text { ah }\end{array}$ & 20 & & & & 452 & $\begin{array}{r}117 \\
47\end{array}$ \\
\hline
\end{tabular}

$\mathrm{Bb}=18$

$f_{t}=20$

$f_{\text {sm }}=6$

$f_{m}=5$

I $=6$ 
sehingga diperoleh nilai median adalah sebagai berikut :

$$
M e=18+\frac{(0,5(20)-6)}{5} 6=18+4,8=22,8 \approx 23
$$

\section{Modus}

Persamaan untuk menghitung modus data dikelompokkan dinyatakan sebagaimana persamaan 4.5 yaitu sebagai berikut

$$
M o=B b+\left(\frac{a}{a+b}\right) I
$$

Berdasarkan tabel frekuensi yang terbentuk diketahui bahwa :

\begin{tabular}{|c|c|c|c|c|c|c|}
\hline $\begin{array}{c}\text { Inter } \\
\text { val }\end{array}$ & $\begin{array}{c}\text { Frekuen } \\
\text { si }(f i)\end{array}$ & $\begin{array}{c}\text { Frekue } \\
\text { nsi } \\
\text { Kumul } \\
\text { atif }\end{array}$ & $\begin{array}{c}\text { Nilai Tengah } \\
(X i)\end{array}$ & $X i^{2}$ & $f i X i$ & $f i X i^{2}$ \\
\hline $6-11$ & 3 & 3 & 8,5 & & 25, & 216, \\
$12-$ & 3 & 6 & 14,5 & 210,2 & 43, & 630, \\
17 & & & & 5 & 5 & 75 \\
\hline
\end{tabular}




\begin{tabular}{|c|c|c|c|c|c|c|}
\hline $\begin{array}{c}18- \\
23\end{array}$ & 5 & 11 & 20,5 & 420,2 & 10 & 210 \\
5 & 2,5 & 1,3 \\
\hline $24-$ & 2 & 15 & 26,5 & 702,2 & & 140 \\
29 & & & & 5 & 53 & 4,5 \\
\hline $30-$ & 7 & 20 & 32,5 & 1056, & 22 & 739 \\
35 & & & & 25 & 7,5 & 3,8 \\
\hline Juml & 20 & & & & 452 & 117 \\
ah & & & & & & 47 \\
\hline
\end{tabular}

$$
\begin{aligned}
& \mathrm{Bb}=30 \\
& a=7-2 \\
& b=7-0 \\
& \mathrm{I} \quad=6
\end{aligned}
$$

sehingga diperoleh nilai modus adalah sebagai berikut :

$$
M o=30+\left(\frac{(7-2)}{(7-2)+(7-0)}\right) 6=30+\left(\frac{5}{12}\right) 6=32,5
$$

\section{Kuartil, Desil dan Persentil}

Persamaan untuk menghitung kuartil, desil dan persentil data dikelompokkan dinyatakan berurutan sebagaimana persamaan 4.6, 4.7 dan 4.8 yaitu sebagai berikut : 
Kuartil

$$
K p=B b+\left(\frac{\frac{p}{4} f_{t}-f_{s p}}{f_{p}}\right) I
$$

Desil

$$
D p=B b+\left(\frac{\frac{p}{10} f_{t}-f_{s p}}{f_{p}}\right) I
$$

Persentil

$$
P p=B b+\left(\frac{\frac{p}{100} f_{t}-f_{s p}}{f_{p}}\right) I
$$

Berdasarkan tabel frekuensi yang terbentuk diketahui bahwa :

Kuartil

$$
\begin{array}{ll}
p=1 & f_{s p}=3 \\
B b=12 & f_{p}=3 \\
f_{t}=20 & I=6
\end{array}
$$

sehingga diperoleh nilai kuartil ke-1 adalah sebagai berikut :

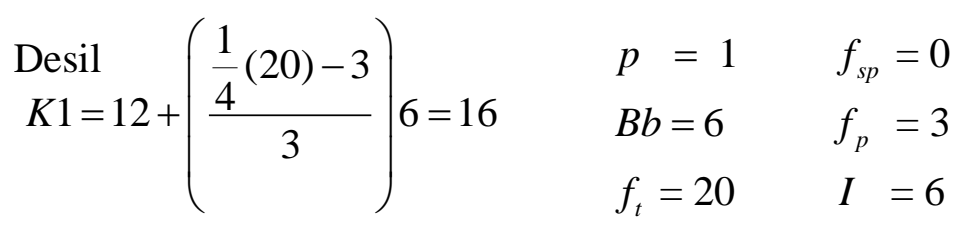


sehingga diperoleh nilai desil ke-1 adalah sebagai berikut :

$$
D 1=6+\left(\frac{\frac{1}{10}(20)-0}{3}\right) 6=10
$$

Persentil

$$
\begin{array}{ll}
p=50 & f_{s p}=3 \\
B b=18 & f_{p}=5 \\
f_{t}=20 & I=6
\end{array}
$$

sehingga diperoleh nilai persentil ke-50 adalah sebagai berikut :
$P 50=18+\left(\frac{\frac{50}{100}(20)-3}{5}\right) 6=26,4$

b. Ukuran penyimpangan data

\section{Ragam atau variance}

Persamaan untuk menghitung ragam (variance) data dikelompokkan dinyatakan sebagaimana persamaan 4.11 yaitu sebagai berikut: 


$$
s^{2}=\frac{\left(\sum_{i=1}^{k} f_{i} X_{i}^{2}-\left(\sum_{i=1}^{k} f_{i} X_{i}\right)^{2} / \sum_{i=1}^{k} f_{i}\right)}{\sum_{i=1}^{k} f_{i}-1}
$$

Berdasarkan tabel frekuensi yang terbentuk diketahui bahwa :

\begin{tabular}{|c|c|c|c|c|c|c|}
\hline $\begin{array}{c}\text { Inter } \\
\text { val }\end{array}$ & $\begin{array}{c}\text { Frekuen } \\
\text { si }(f i)\end{array}$ & $\begin{array}{c}\text { Frekuensi } \\
\text { Kumulatif }\end{array}$ & $\begin{array}{c}\text { Nilai } \\
\text { Tengah } \\
(X i)\end{array}$ & $X i^{2}$ & $f i X i$ & $f i X i^{2}$ \\
\hline $6-11$ & 3 & 3 & 8,5 & & 25, & 216, \\
& & & & 72,25 & 5 & 75 \\
\hline $12-$ & 3 & 6 & 14,5 & 210,2 & 43, & 630, \\
17 & & & & 5 & 5 & 75 \\
\hline $\begin{array}{c}18- \\
23\end{array}$ & 5 & 11 & 20,5 & 420,2 & 10 & 210 \\
\hline $24-$ & 2 & 15 & 26,5 & 702,2 & & 140 \\
29 & & & & 5 & 53 & 4,5 \\
\hline $30-$ & 7 & 20 & 32,5 & 1056, & 22 & 739 \\
35 & & & & 25 & 7,5 & 3,8 \\
\hline Juml & 20 & & & & 452 & 117 \\
ah & & & & & 47 \\
\hline
\end{tabular}




$$
\begin{aligned}
& \sum_{i=1}^{k} f_{i} X_{i}^{2}=11747 \\
& \sum_{i=1}^{k} f_{i} X_{i}=452 \\
& \sum_{i=1}^{k} f_{i}=20
\end{aligned}
$$

Sehingga nilai ragam (variance) adalah :

$$
s^{2}=\frac{\left(\sum_{i=1}^{k} f_{i} X_{i}^{2}-\left(\sum_{i=1}^{k} f_{i} X_{i}\right)^{2} / \sum_{i=1}^{k} f_{i}\right)}{\sum_{i=1}^{k} f_{i}-1}=\frac{\left(11.747-(452)^{2} / 20\right)}{19}=\frac{(11747-10215,2)}{19}=80,62
$$

Simpangan baku atau standart deviasi adalah akar dari ragam (variance). Sehingga simpangan baku untuk data tersebut adalah

$$
s=\sqrt{\frac{\left(\sum_{i=1}^{k} f_{i} X_{i}^{2}-\left(\sum_{i=1}^{k} f_{i} X_{i}\right)^{2} / \sum_{i=1}^{k} f_{i}\right)}{\sum_{i=1}^{k} f_{i}-1}}=\sqrt{\frac{(11747-10215,2)}{19}}=8,98
$$




\subsection{Rangkuman}

- Terdapat dua jenis ukuran pemusatan dan penyimpangan data, yaitu untuk data dikelompokkan dan data tidak dikelompokkan.Data yang dikelompokkan adalah data yang sudah disajikan dalam tabel frekuensi.

- Ukuran Pemusatan data

\section{Data tidak dikelompokkan}

a. Rata-rata

b. Median

$$
\begin{aligned}
& \text { c. Mydy } \\
& \bar{x}=\frac{\sum_{i=1}^{n} \mathrm{~d}}{n}
\end{aligned}
$$

untuk $\mathrm{n}$ ganjil $\rightarrow \mathrm{Me}=X_{(n+1) / 2}$

untuk n genap $\rightarrow \mathrm{Me}=\frac{X_{(n / 2)}+X_{(n / 2+1)}}{2}$

Nilai yang paling sering muncul

Data tidak dikelompokkan
a. Rata-rata
b. Median
c. Modus

$$
\bar{x}=\frac{\sum_{i=1}^{k} f_{i} X_{i}}{\sum_{i=1}^{k} f_{i}}
$$$$
M e=B b+\frac{\left(0,5 f_{t}-f_{s m}\right)}{f_{m}} I
$$$$
M o=B b+\left(\frac{a}{a+b}\right) I
$$ 

d. Kuartil
e. Desil
f. Persentil

$K p=B b+\left(\frac{\frac{p}{4} f_{t}-f_{s p}}{f_{p}}\right) I \quad D p=B b+\left(\frac{\frac{p}{10} f_{t}-f_{s p}}{f_{p}}\right) I \quad P p=B b+\left(\frac{\frac{p}{100} f_{t}-f_{s p}}{f_{p}}\right) I$

- Ukuran Penyimpangan Data

$\underline{\text { Data tidak dikelompokkan }}$

a. Range

b. Ragam

$$
R=\mathrm{X}_{\max }-\mathrm{X}_{\min }
$$

$$
s^{2}=\frac{\left(\sum_{i=1}^{n} X_{i}^{2}-\left(\sum_{i=1}^{n} X_{i}\right)^{2} / n\right)}{n-1}
$$

c. Simpangan Baku

$$
s=\sqrt{\frac{\left(\sum_{i=1}^{n} X_{i}^{2}-\left(\sum_{i=1}^{n} X_{i}\right)^{2} / n\right)}{n-1}}
$$

\section{$\underline{\text { Data dikelompokkan }}$}

a. Range

$$
s^{2}=\frac{\left(\sum_{i=1}^{k} f_{i} X_{i}^{2}-\left(\sum_{i=1}^{k} f_{i} X_{i}\right)^{2} / \sum_{i=1}^{k} f_{i}\right)}{n-1}
$$

c. Simpangan Baku

$$
R=\mathrm{X}_{\max }-\mathrm{X}_{\min }
$$

b. Ragam

$$
s=\sqrt{\frac{\left(\sum_{i=1}^{k} f_{i} X_{i}^{2}-\left(\sum_{i=1}^{k} f_{i} X_{i}\right)^{2} / \sum_{i=1}^{k} f_{i}\right)}{n-1}}
$$




\subsection{Latihan}

1. Menggunakan soal yang sama pada bab tabel frekuensi yaitu data nilai UAS 30 mahasiswa pada matakuliah dasardasar pemrograman, hitunglah ukuran pemusatan dan penyimpangan data baik untuk data yang tidak dikelompokkan dan data dikelompokkan. Data disajikan pada tabel sebagai berikut :

\begin{tabular}{|l|l|l|l|l|l|l|l|l|l|}
\hline 75 & 73 & 69 & 63 & 85 & 60 & 67 & 76 & 78 & 89 \\
\hline 91 & 74 & 77 & 73 & 78 & 77 & 69 & 84 & 64 & 79 \\
\hline 75 & 72 & 71 & 67 & 66 & 81 & 87 & 75 & 76 & 78 \\
\hline
\end{tabular}

2. Berikut ini merupakan tabel frekuensi berat badan 25 siswa kelas 6 sebuah Sekolah Dasar:

\begin{tabular}{c|c}
\hline Kelas & $\begin{array}{c}\text { Frekuensi } \\
(f)\end{array}$ \\
\hline $0-34$ & 4 \\
\hline $5-39$ & 9 \\
\hline $0-44$ & 6 \\
\hline $5-49$ & 4 \\
\hline & 2 \\
\hline
\end{tabular}




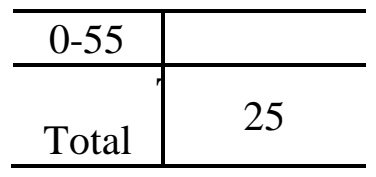

Hitunglah ukuran pemusatan dan penyebaran data untuk data dikelompokkan berdasarkan tabel frekuensi di atas !

3. Menggunakan hasil pengumpulan data berat badan dan tinggi badan dikelas pada bab tabel frekuensi, hitunglah ukuran pemusatan dan penyebaran data baik untuk data tidak dikelompokkan dan data dikelompokkan!

\section{Daftar Pustaka}

Supranto, J. (2008). Statistik Teori dan Aplikasi. Jakarta : Erlangga.

Walpole, Ronald E. (1995). Pengantar Statistika. Jakarta : PT. Gramedia Pustaka Utama.

Yitnosumarto, Suntoyo. (1990). Dasar-Dasar Statistika. Jakarta: Rajawali Pers. 
Halaman Ini Sengaja Dikosongkan 


\section{BAB 5 \\ PROBABILITAS}

\subsection{Pendahuluan}

Dalam statistika inferensi, probabilitas berperan penting. Wibisono (2009) menyatakan bahwa probabilitas adalah peluang atau kebolehjadian, yaitu peristiwa yang didefinisikan sebagai kemungkinan terjadinya suatu peristiwa (event). Contoh penggunaan probabilitas dalam aktivitas sehari-hari adalah seorang pedagang mempunyai 2 (dua) pilihan untuk membeli barang dagangannya. Jika dia membeli hari ini, harganya setiap kilo adalah Rp 10.000, namun jika membeli besok harganya akan naik $2 \%$ setiap kilonya. Keputusannya adalah apakah pedagang tersebut akan membeli barang dagangannya sekarang atau esok hari?. Sehingga keputusan yang diambil oleh pedagang tersbut berhubungan dengan peluang untuk mendapatkan laba yang lebih banyak. Probabilitas (peluang) dapat didefinisikan sebagai nilai dari 0 sampai 1 yang menunjukkan seberapa besar kemungkinan terjadinya suatu peristiwa. Probabilitas (peluang) memegang peranan penting dalam statistika inferensia. Hubungan antara populasi dan sampel didasarkan pada teori probabilitas (peluang). Dengan demikian 
pengetahuan mengenai peluang sangat diperlukan. Berbicara tentang probabilitas (peluang), tentu erat kaitannya dengan suatu percobaan (eksperimen). Percobaan (eksperimen) dapat didefinisikan sebagai pengamatan terhadap beberapa aktivitas atau proses yang memungkinkan timbulnya paling sedikit dua peristiwa tanpa memperhatikan peristiwa mana yang akan terjadi. Kejadian yang mungkin didapatkan dalam suatu percobaan disebut sebagai hasil. Kumpulan dari satu atau lebih hasil yang terjadi pada sebuah percobaan (eksperimen) disebut sebagai ruang contoh. Hasil akhir pada suatu percobaan (eksperimen) disebut sebagai peristiwa (Yitnosumarto,1990).

\subsection{Konsep Probabilitas}

Terdapat beberapa definisi dan pengertian yang berhubungan dengan konsep probabilitas, yaitu:

1. Eksperimen (Percobaan) adalah aksi/proses pengamatan yang membeawa kita kepada satu hasil yang tidak dapat diprediksi dengan pasti.

2. Titik Sampel adalah hasil yang paling mendasar dari suatu eksperimen.

3. Peristiwa adalah kumpulan khusus/tertentu dari titik sampel. 
4. Ruang sampel adalah kumpulan dari semua titik sampelnya.

Contoh : Terdapat dua koin uang logam, terdiri dari gambar (G) dan angka (A). Tentukan:
a. Ruang sampelnya.
b. Gambarkan diagram venn-nya
c. Peluang muncul $1 \mathrm{~A}$ dan $1 \mathrm{G}$
d. Peluang muncul $2 \mathrm{G}$
e. Peluang muncul $2 \mathrm{~A}$

Jawab:

a. Ruang sampelnya adalah AA, AG, GA, GG

b.

\begin{tabular}{|ccc|}
\hline$S$ & GA & AG \\
& AA & GG \\
& & \\
\hline
\end{tabular}

c. Peluang muncul $1 \mathrm{~A}$ dan $1 \mathrm{G}$ adalah $: 2 / 4$

d. Peluang muncul $2 \mathrm{G}: 1 / 4$

e. Peluang muncul $2 \mathrm{~A}: 1 / 4$

Jadi, aturan dalam probabilitas titik sampel adalah:

1. Semua probabilitas titik sampel harys terletak antara 0 dan 1 
2. Jumlah semua probabilitas itik sampel dalam ruang sampel harus berharga 1 .

3. Berikut akan diberikan ilustrasi mengenai perbedaan antara tiga unsur yaitu percobaan (eksperimen), hasil dan peristiwa dalam probabilitas (peluang) yang disajikan pada Tabel sebagai berikut.

Tabel. Ilustrasi Percobaan Pelemparan Satu Mata Uang Logam

\begin{tabular}{|l|l|}
\hline Percobaan (eksperimen) & $\begin{array}{l}\text { Pelemparan satu mata uang } \\
\text { logam Rp. 500,- }\end{array}$ \\
\hline Hasil & $\begin{array}{l}\text { Sisi gambar dilambangkan } \\
\text { dengan G } \\
\text { Sisi angka dilambangkan } \\
\text { dengan A }\end{array}$ \\
\hline Peristiwa & $\begin{array}{l}\text { Sisi Angka dilambangkan } \\
\text { dengan A }\end{array}$ \\
\hline
\end{tabular}

Apabila dua mata uang logam Rp. 500,- tersebut dilemparkan maka hasil yang mungkin pada percobaan (eksperimen) tersebut adalah GG yaitu pelemparan mata uang logam pertama hasilnya $\mathrm{G}$ dan pelemparan mata uang logam kedua hasilnya $G$ atau GA yaitu pelemparan mata uang logam pertama hasilnya $\mathrm{G}$ dan pelemparan mata uang logam kedua hasilnya A atau AG yaitu pelemparan mata uang logam 
pertama hasilnya A dan pelemparan mata uang logam kedua hasilnya $G$ atau AA yaitu pelemparan mata uang logam pertama hasilnya A dan pelemparan mata uang logam kedua hasilnya A. Sehingga hasil yang mungkin pada percobaan (eksperimen) tersebut adalah GG, GA, AG dan AA. Berdasarkan percobaan (eksperimen) yang dilakukan ternyata sisi yang muncul adalah sisi angka untuk mata uang logam pertama dan sisi gambar untuk mata uang logam yang kedua. Sehingga peristiwa dari percobaan (eksperimen) tersebut adalah AG (pelemparan mata uang logam pertama hasilnya A dan pelemparan mata uang logam kedua hasilnya G). Hasil yang mungkin pada suatu percobaan (eksperimen) juga disebut sebagai ruang contoh (sample space) dan pada umumnya dilambangkan dengan $\mathrm{S}$ yang dianggap sebagai gugus semesta. Untuk percobaan satu mata uang logam gugus semesta adalah $S=\{G, A\}$ sedangkan untuk dua mata uang logam gugus semesta adalah $S=\{G G, G A, A G, A A\}$. Seperti halnya pelemparan satu mata uang logam, untuk lebih jelas mengenai ilustrasi pelemparan dua mata uang logam maka akan disajikan dalam bentuk tabel sebagai berikut. 
Tabel. Ilustrasi Percobaan Pelemparan Dua Mata Uang Logam

\begin{tabular}{|l|l|}
\hline Percobaan (eksperimen) & $\begin{array}{l}\text { Pelemparan dua mata uang } \\
\text { logam Rp. 500,- }\end{array}$ \\
\hline Hasil (Ruang Contoh) & $\begin{array}{l}\text { GG (Sisi Gambar dan Sisi } \\
\text { Gambar) } \\
\text { GA (Sisi Gambar dan Sisi } \\
\text { Angka) } \\
\text { AG (Sisi Angka dan Sisi } \\
\text { Gambar) } \\
\text { AA (Sisi Angka dan Sisi } \\
\text { Angka) }\end{array}$ \\
\hline Peristiwa & $\begin{array}{l}\text { Sisi Angka dilambangkan } \\
\text { dengan A }\end{array}$ \\
\hline
\end{tabular}

Tabel. Ilustrasi Percobaan (eksperimen), Hasil dan Peristiwa

\begin{tabular}{|l|l|}
\hline Percobaan (eksperimen) & $\begin{array}{l}\text { Pertandingan sepak bola liga } \\
\text { indonesia antara persela vs } \\
\text { persik }\end{array}$ \\
\hline Hasil & $\begin{array}{l}\text { Persela menang } \\
\text { Persela kalah } \\
\text { Seri }\end{array}$ \\
\hline Peristiwa & Persela kalah \\
\hline
\end{tabular}


Ilustrasi lain misalkan percobaan (eksperimen) yang dilakukan adalah pelemparan sebuah mata uang logam Rp. 500,- . Sisi gambar pada mata uang Rp. 500,- dilambangkan dengan huruf $G$ ( $G$ untuk gambar) dan sisi yang lain pada mata uang Rp. 500,- dilambangkan dengan huruf A (A untuk angka). Mata uang Rp. 500,- tersebut dilemparkan sekali maka yang tampak pada bagian atas dicatat dan tentu sisi yang muncul adalah $\mathrm{G}$ atau $\mathrm{A}$ sehingga sisi selain itu tidak mungkin terjadi. Munculnya sisi G atau A dinamakan sebagai hasil dalam percobaaan (eksperimen). Munculnya sisi $\mathrm{G}$ atau A dinamakan juga sebagai hasil yang mungkin terjadi karena selain $\mathrm{G}$ dan A tidak mungkin ada hasil lain yang terjadi. Berdasarkan percobaan (eksperimen) yang dilakukan ternyata sisi yang muncul adalah sisi angka atau dilambangkan dengan huruf A. Sehingga peristiwa dari percobaan (eksperimen) tersebut adalah A (A untuk Angka). Percobaaan (eksperimen) yang dilakukan disebut juga sebagai percobaan acak karena saat dilakukan pelemparan mata uang logam tidak diketahui pasti apakah hasil tersebut benar-benar terjadi secara acak (random) atau secara kebetulan. Untuk lebih jelas mengenai ilustrasi pelemparan mata uang logam maka akan disajikan dalam bentuk tabel sebagai berikut : 


\subsection{Gabungan dan Irisan}

Gabungan (union) dan irisan (intersection) adalah dua konsep operasi himpunan yang terdapat pada teori himpunan. Gabungan 2 peristiwa A dan B adalah peristiwa yang terjadi jika A terjadi atau B terjadi atau keduanya terjadi secara bersamaan. Simbolnya adalah A $\cup$ B.

Irisan 2 peristiwa $\mathrm{A}$ dan $\mathrm{B}$ adalah peristiwa yang terjadi jika A dan B terjadi secara bersamaan. Simbolnya adalah $\mathrm{A} \sim \mathrm{B}$.

Contoh:

Terdapat 2 peristiwa $\mathrm{A}=$ \{pelemparan 1 dadu yang menghasilkan bilangan genap $\}$ dan $\mathrm{B}=\{$ pelemparan 1 dadu yang menghasilkan bilangan yang kurang dari atau sama dengan 3 \}. Tentukan $\mathrm{A} \cup \mathrm{B}$ dan $\mathrm{A} \sim \mathrm{B}$.

Jawab:

Peristiwa $A \cup B=\{1,2,3,4,6\}$ dan peristiwa $A \cap B=\{2\}$. Jika diandaikan dadu tersebut eimbang, maka $\mathrm{P}(\mathrm{A} \cup \mathrm{B})=5 / 6$ dan $\mathrm{P}(\mathrm{A} \cap \mathrm{B})=1 / 6$.

\subsection{Probabilitas Bersyarat}

Merupakan probabilitas yang mengikutsertakan tambahan pengetahuan (informasi) lain. Untuk menentukan probabilitas A terjadi apabila diketahui bahwa peristiwa B 
terjadi, kita dapat membagi probabilitas $\mathrm{A} \cap \mathrm{B}$ terjadi dengan probabilitas B terjadi.

$$
\mathrm{P}(\mathrm{A} \mid \mathrm{B})=\frac{\mathrm{P}\left(\mathrm{A}^{\cap} \mathrm{B}\right)}{\mathrm{P}(\mathrm{B})}
$$

\subsection{Aturan Perkalian Dan Peristiwa Independen}

Aturan perkalian untuk probabilitas adalah sebagai berikut:

$$
\mathrm{P}(\mathrm{A} \cap \mathrm{B})=\mathrm{P}(\mathrm{A}) . \mathrm{P}(\mathrm{B} \mid \mathrm{A})
$$

Atau

$$
\mathrm{P}(\mathrm{A} \cap \mathrm{B})=\mathrm{P}(\mathrm{B}) . \mathrm{P}(\mathrm{A} \mid \mathrm{B})
$$

Peristiwa A dan B adalah peristiwa "independen" jika terjadinya peristiwa $\mathrm{B}$ tidak mempengaruhi terjadinya peristiwa A sehingga $P(\mathrm{~A} \mid \mathrm{B})=P(\mathrm{~A})$. demikian pula, jika A dan $\mathrm{B}$ independen, maka $P(\mathrm{~B} \mid \mathrm{A})=\mathrm{P}(\mathrm{B})$ adalah benar. Jika peristiwa A dan B independen, probabilitas irisan peristiwa A dan B sama dengan hasil kali probabilitas A dan probabilitas B sehingga $P(\mathrm{~A} \mid \mathrm{B})=\mathrm{P}(\mathrm{A}) \cdot \mathrm{P}(\mathrm{B})$.

\section{Contoh:}

Kita ambil satu kartu secara acak dari satu set kartu brige yang berjumlah 52 buah, kemudian kita kembalikan lagi kartu tersebut dan kita acak lagi tumpukan kartu untuk mengambil 
kartu kedua sehingga diperoleh hasil A1 = (didapat As pada pengambilan I) dan $\mathrm{A} 2=($ didapat As pada pengambilan II maka

$$
\mathrm{P}\left(\mathrm{A}_{1} \cap \mathrm{A}_{2}\right)=\mathrm{P}\left(\mathrm{A}_{1}\right) . \mathrm{P}\left(\mathrm{A}_{2}\right)=(4 / 52)(4 / 52)=1 / 169 .
$$

Dalam hal ini A1 dan A2 adalah peristiwa yang independen.

\subsection{Beberapa Aturan Perhitungan/Pencacahan}

Aturan sederhana yang digunakan untuk mencacah ataumenghitung adalah:

\section{Aturan perkalian}

Terdapat beberapa himpunan dari elemen-elemen dimana $\mathrm{n} 1$ berada dalam himpunan pertama, $\mathrm{n} 2$ berada dalam himpunan kedua ,... dan $\mathrm{n} 2$ berada dalam himpunan yang ke-k, kita ingin membentuk sampel yang terdiri $\mathrm{k}$ elemen dengan mengambil satu elemen dari tiap $\mathrm{k}$ himpunan. Sampel berbeda yang dapat dibentuk adalah:

$$
\mathrm{n}_{1} \cdot \mathrm{n}_{2} \cdot \mathrm{n}_{3} \ldots \mathrm{nk}
$$

Contoh :

Dalam kantong plastik terdapat 3 kelereng merah dan 2 kelereng hijau. Ada berapa carakah memilih 2 kelereng yang terdiri dari 1 merah dan 1 kelereng hijau?

Jawab: Terdapat (3).(2) $=6$ cara. 


\section{Aturan Permutasi}

Diberikan himpunan tnggal yang terdiri dari $\mathrm{N}$ elemen yang berbeda. Kita ingin memilih $\mathrm{n}$ elemen dari $\mathrm{N}$ dan mengatur mereka dalam n posisi. Banyaknya permutasi yang berbeda dari $\mathrm{N}$ elemen yang diambil $\mathrm{n}$ pada sekali waktu disimbolkan dengan $P_{n}^{N}$ dan dirumuskan sebagai

$$
P_{n}^{N}=N(N-1)(N-2)(n-3) \ldots(N-n+1)=\frac{N !}{(N-n) !} .
$$

Dimana, $\mathrm{n} !=\mathrm{n}(\mathrm{n}-1)(\mathrm{n}-2)(\mathrm{n}-3) \ldots 3.2 .1$ disebut $\mathrm{n}$ factorial.

Contoh:

Terdapat berapa cara untuk memilih 2 huruf dari himpuan 3 huruf $(\mathrm{X}, \mathrm{Y}, \mathrm{Z})$ apabila urutannya diperhitungkan?

Jawab:

$$
P_{2}^{3}=\frac{3 !}{(3-2) 1}=\frac{3 !}{1 !}=\frac{3 \cdot 2 \cdot 1}{1}=6
$$

Jadi, terdapat 6 cara yaitu : (X,Y); (Y,Z); (Z, X); (X,Z); (Y, $\mathrm{X}) \operatorname{dam}(\mathrm{Z}, \mathrm{Y})$. 


\section{Aturan Partisi}

Terdapat himpunan tunggal yang terdiri dari $\mathrm{N}$ elemen yang berbeda. Kita mempartisi mereka ke dalam k himpunan, dengan himpunan pertama memuat $\mathrm{n}_{1}$ elemen, himpunan kedua memuat $\mathrm{n}_{2}$ elemen,... dan himpunan ke-k memuat $\mathrm{n}_{\mathrm{k}}$ elemen. Banyaknya partisi yang berbeda adalah:

$$
\frac{N !}{n_{1} ! n_{2} ! n_{3} ! \ldots n_{k} !} \text { dengan } \mathrm{n}_{1}+\mathrm{n}_{2}+\mathrm{n}_{3}+\ldots+\mathrm{n}_{\mathrm{k}}=\mathrm{N}
$$

Contoh:

Ada berapa banyak cara untuk mempartisi himpunan $\{1,2,3,4\}$ ke dalam 3 himpunan, Diana himpunan pertama memuat 2 elemen, himpunan kedua memuat 1 elemen dan himpunan ketiga memuat 1 elemen?

Jawab:

Terdapat $: \frac{4 !}{2 ! 1 ! 1 !}=12$ 


\section{Aturan Kombinasi}

Suatu sampel terdiri dari n elemen yang dipilih dari himpunan $\mathrm{N}$ elemen. Banyaknya sampel berbeda yang terdiri dari $\mathrm{n}$ elemen yang dipilih dari $\mathrm{N}$, disimbolkan dengan:

$$
\left(\begin{array}{l}
N \\
n
\end{array}\right)=\frac{N !}{n !(N-n) !}
$$

Contoh:

Terdapat berapa cara untuk memilih 2 huruf dari himpunan 3 huruf $(\mathrm{A}, \mathrm{B}, \mathrm{C})$ apabila urutan tidak diperhitungkan?

Jawab:

$\left(\begin{array}{l}3 \\ 2\end{array}\right)=\frac{3 !}{2 !(3-2) !}=\frac{3 !}{2 ! 1 !}=3$, Sehingga terdapat 3 cara.

\section{Ruang Contoh Diskrit dan Kontinyu}

Terdapat dua jenis ruang contoh (sampel space) pada teori probabilitas (peluang) yaitu ruang contoh diskrit dan ruang contoh kontinyu. Secara singkat telah dijelaskan pada pendahuluan bahwa ruang contoh adalah hasil yang mungkin terjadi pada suatu percobaan (eksperimen). 
Ruang sampel diskrit dapat didefinisikan sebagai ruang sampel yang mempunyai banyak anggota berhingga atau tidak berhingga tetapi dapat dihitung. Gambaran mengenai ruang sampel diskrit telah dicontohkan pada 3 ilustrasi dibagian pendahuluan yaitu pada pertandingan sepak bola, pelemparan satu mata uang logam dan pelemparan dua mata uang logam. Sebagai tambahan akan diberikan satu lagi ilustrasi tentang ruang sampel diskrit.

Apabila dilakukan sebuah percobaan (eksperimen) mengenai pengundian sebuah dadu, maka ruang contoh pada percobaan (eksperimen) tersebut berisi salah satu dari hasil sebagai berikut: mata dadu 1, mata dadu 2, mata dadu 3, mata dadu 4, mata dadu 5 dan mata dadu 6. Sehingga ruang contoh pada percobaan mengenai pengundian sebuah dadu yaitu $S=\{1,2$, 3, 4, 5, 6\}. Dalam hal ini mata dadu 1 saja, mata dadu 2 saja, mata dadu 3 saja, mata dadu 4 saja, mata dadu 5 saja dan mata dadu 6 saja masing-masing dinamakan sebagai titik-titik contoh.

(Walpole, 1995)

Ruang sampel kontinyu dapat didefinisikan sebagai ruang sampel yang anggotanya merupakan interval pada garis bilangan real. Penjelasan tentang ruang sampel kontinyu akan diberikan melalui ilustrasi sebagai berikut. Misalkan sebuah 
perusahaan bola lampu memproduksi sebuah bola lampu baru. Tentukan masa hidup (dalam jam) bola lampu yang diproduksi oleh perusahaan tersebut. Karena masa hidup bola lampu bernilai bilangan real positif maka ruang sampelnya adalah $S=\{t: t>0\}$. Pada kasus tersebut dapat ditentukan beberapa peristiwa dari ruang sampel S. Pada bagian pendahuluan dijelaskan bahwa peristiwa adalah kumpulan dari satu atau lebih hasil yang terjadi pada sebuah percobaan (eksperimen). Definisi lain dari peristiwa adalah sebuah himpunan bagian dari ruang sampel S. Notasi untuk mnyatakan peristiwa pada umumnya ditulis dengan huruf kapital, misalnya A, B, C, D dan sebagainya kecuali S. Karena sebuah peristiwa merupakan himpunan bagian dari ruang sampel $\mathrm{S}$ maka terdapat 3 kemungkinan yang dapat terjadi dalam suatu peristiwa yaitu :

1. S itu sendiri merupakan sebuah peristiwa

2. $\varnothing$ (himpunan kosong) juga merupakan sebuah peristiwa

3. Beberapa hasil yang mungkin dari $\mathrm{S}$ merupakan sebuah peristiwa

Aapabila dilakukan sebuah percobaan (eksperimen) maka akan diperoleh hasil-hasil yang mungkin berdasarkan 
percobaan (eksperimen) tersebut yang dinamakan sebagai ruang sampel. Sama halnya seperti percobaan (eksprimen), apabila peristiwa dapat ditentukan maka hasil hasil yang termasuk dalam peristiwa tersebut juga dapat ditentukan.

(Walpole, R. E., \& Myers, R. H, 1986)

\section{Pendekatan Klasik dan Empiris Pada Probabilitas (Peluang)}

Pendekatan klasik dapat didefinisikan sebagai besarnya probalitas (peluang) apabila hasil dari suatu percobaan (eksperiment) mempunyai kesempatan yang sama untuk terjadi. Apabila terdapat a kemungkinan yang dapat terjadi pada hasil percobaan A dan terdapat $\mathrm{b}$ kemungkinan yang dapat terjadi pada hasil percobaan A, serta masing-masing kejadian mempunyai kesempatan yang sama untuk terjadi, maka probabilitas(peluang) bahwa akan terjadi hasil a pada suatu percobaan (eksperiment) dapat dinyatakan sebagaimana persamaan sebagai berikut:

$$
P(A)=\frac{a}{a+b}
$$

Berdasarkan definisi tersebut maka dapat dituliskan beberapa sifat probabilitas (peluang) sebagai berikut : 
a. Untuk setiap A dalam S (Ruang Contoh)

$$
0<P(A)<1
$$

b. Dalam suatu percobaan (eksperiment) kemungkinan kejadian ada 2, yaitu "terjadi" (P(A)) atau "tidak terjadi" $\left(\mathrm{P}(\mathrm{A})^{\prime}\right)$, maka jumlah probabilitas total adalah :

$$
P(S)=1 \quad \text { atau } \quad P(A)+P(A)^{\prime}=1
$$

c. Apabila $A_{1}, A_{2}, \ldots, A_{k}$ adalah hasil dari suatu percobaan yang mutual eksklusif (kejadian yang tidak dapat terjadi secara bersama-sama dengan kejadian lainnya) dalam $\mathrm{S}$ maka :

$$
P\left(\bigcup_{i=1}^{k} A_{i}\right)=P\left(A_{1}\right)+P\left(A_{2}\right)+\cdots+P\left(A_{k}\right)
$$

Berbeda dengan pendekatan klasik, pada pendekatan empiris besar probabilitas (peluang) suatu percobaan (eksperiment) tidak dianggap sama, tetapi tergantung pada berapa banyak suatu hasil terjadi dari keseluruhan percobaan (eksperiment) yang dilakukan. Pada umumnya perdekatan empiris dilakukan berulang-ulang. Hal ini didasarkan pada kenyataan bahwa kesempatan yang sama untuk terjadi sebagaimana pendekatan klasik tidak selamanya bisa dipenuhi. Maka probabilitas(peluang) berdasarkan 
pendekatan empiris pada suatu percobaan (eksperiment) dapat dinyatakan sebagaimana persamaan sebagai berikut:

$$
P(A)=\frac{\text { Jumlah Hasil Yang Terjadi }}{\text { Jumlah Seluruh Percobaan }(\text { Eksperiment })} \text { atau } P(A)=\frac{n a}{N}
$$

(Supranto, 2008). 


\section{Contoh Soal}

1. Pelamar pekerjaan terdiri dari 10 orang pria (a) dan 15 orang wanita (b). Jika yang diterima hanya 1, berapa probabilitas (peluang) bahwa pelamar yang diterima merupakan pelamar wanita?

Jawab:

$n b=15$

$N=15+10=25$

$P(A)=\frac{n b}{N}=\frac{15}{25}=0,6$

Jadi probabilitas (peluang) bahwa pelamar yang diterima merupakan pelamar wanita adalah sebesar 0,6 atau $60 \%$.

2. Dari hasil penelitian diketahui bahwa 5 orang siswa akan terserang flu pada musim dingin. Apabila diadakan kemah pada daerah yang dingin, maka berapa probabilitas (peluang) terjadi 1 orang siswa sakit flu dari 400 orang siswa yang ikut serta?

Jawab:

$n a=5$

$N=400$ 
$P(A)=\frac{5}{400}=0,0125$

Jadi probabilitas (peluang) terjadi 1 orang siswa sakit flu dari 400 orang siswa yang ikut serta adalah 0,0125 atau $1,25 \%$

\subsection{Rangkuman}

1. Probabilitas adalah peluang atau kebolehjadian, yaitu peristiwa yang didefinisikan sebagai kemungkinan terjadinya suatu peristiwa (event).

2. Dalam konsep probabilitas terdapat 4 konsep, yaitu:

a. Eksperimen

b. Titik Sampel

c. Ruang Sampel

d. Peristiwa

3. Dalam teori probabilitas terdapat gabungan dan irisin.

4. Probabilitas bersyarat adalah probabilitas yang mengikutsertakan tambahan informasi.

5. Terdapat beberapa aturan perhitungan atau pencacahan, yaitu:

a. Aturan perkalian 

b. Aturan permutasi
c. Aturan partisi
d. Aturan Kombinasi

6. Probabilitas (peluang) didefinisikan sebagai nilai dari 0 sampai 1 yang menunjukkan seberapa besar kemungkinan terjadinya suatu peristiwa.

7. Terdapat beberapa istilah penting pada teori probabilitas yaitu percobaan (esperimen), hasil, ruang contoh dan peristiwa. Percobaan (eksperimen) ddefinisikan sebagai pengamatan terhadap beberapa aktivitas atau proses yang memungkinkan timbulnya paling sedikit dua peristiwa tanpa memperhatikan peristiwa mana yang akan terjadi. Hasil didefinisikan sebagai kejadian yang mungkin didapatkan dalam suatu percobaan. Ruang contoh didefinisikan sebagai kumpulan dari satu atau lebih hasil yang terjadi pada sebuah percobaan (eksperimen). Peristiwa didefinisikan sebagai hasil akhir pada suatu percobaan (eksperimen) disebut sebagai.

8. Ruang sampel diskrit didefinisikan sebagai ruang sampel yang mempunyai banyak anggota 
berhingga atau tidak berhingga tetapi dapat dihitung.

9. Ruang sampel kontinyu didefinisikan sebagai ruang sampel yang anggotanya merupakan interval pada garis bilangan real.

10. Pendekatan klasik didefinisikan sebagai besarnya probalitas (peluang) apabila hasil dari suatu percobaan (eksperiment) mempunyai kesempatan yang sama untuk terjadi.

11. Pendekatan empiris didefinisikan sebagai besarnya probabilitas (peluang) suatu percobaan (eksperiment) tidak dianggap sama, tetapi tergantung pada berapa banyak suatu hasil terjadi dari keseluruhan percobaan (eksperiment) yang dilakukan. 


\section{Latihan}

1. Apakah yang dimaksud dengan :
a. Statistik
b. Ruang Sampel
c. Titik Sampel
d. Peristiwa
e. Permutasi
f. Beri contoh masing-masing pengertian di atas

2. Tuliskan anggota ruang sampel berikut ini :

a. Himpunan bilangan bulat antara 1 dan 50 yang habis dibagi 8.

b. Himpunan bilangan ganjil antara 1 dan 77 yang habis dibagi 7.

3. Bila ada diketahui :

a. $T=\{0,1,2,3,4,5,6,7,8,9\}$ dan $\mathrm{A}=\{0,2,4,6,8\}, \mathrm{B}=$ $\{1,3,5,7,9\}, \quad C=\{2,3,4,5\}$ dan $\mathrm{D}=\{1,6,7\}$, tuliskan anggota himpunan yang berkaitan dengan kejadian :

- A U C

- $\mathrm{A} \cap \mathrm{B}$

b. $T=\{$ Tembaga, natrium, nitrogen, kalium, uranium,oksigen,seng $\}$ dan kejadian $\mathrm{A}=$ \{tembaga, natrium, seng $\}, B=\{$ natrium, kalium, 
nitrogen $\}$, dan $\mathrm{C}=$ \{oksigen $\}$, tuliskan anggota himpunan yang berkaitan dengan kejadian berikut

- A UC

- $\quad A \cap B$

4. Dalam setangan pemain poker terdapat 5 kartu, hitunglah peluangnya mendapatkan 2 As dan 3 jack. Dan berapa peluang dari 5 kartu yang berada ditangan pemain poker?

5. Pada keranjang buah yang berisi 20 buah apel terdapat delapan apel merah (M) dan duabelas apel hijau (H). Diambil 4 buah apel secara acak dan pada pengambilan selanjutnya apel dikembalikan lagi. Tentukan peluang untuk memperoleh :

a. Keempatnya apel merah

b. Paling sedikit 2 apel merah

c. Paling banyak dua apel hijau

d. Apel merah dan hijau berurutan

6. Dalam ruang kuliah terdapat 10 mahasiswa; 4 laki-laki dan 6 perempuan. Jika ditunjuk secara acak diantara mereka tentukan peluang mahasiswa yang ditunjuk adalah mahasiswa perempuan! 
7. Apabila suatu keluarga yang mempunyai 3 orang anak mempunyai peluang terlahirnya anak laki-laki adalah 0,5 tanpa memperhatikan urutan kelahiran, maka tentukan :
a. Ruang contoh untuk kelahiran anak tersebut
b. Peluang bahwa ketiga anak berjenis kelamin sama
c. Peluang paling sedikit satu anak perempuan dalam keluarga tersebut

\section{Daftar Pustaka}

Santosa, R. Gunawan (2004)., Statistik., Yogyakarta: Andi Sudjana (2005)., Metoda Statistika., Bandung: Tarsito Supranto, J. (2008). Statistik Teori dan Aplikasi. Jakarta : Erlangga.

Walpole, R. E., \& Myers, R. H. (1986). Ilmu peluang dan

Statistika untuk Insinyur dan Ilmuwan (R. K. Sembiring, Trans.). Bandung: Penerbit ITB.

Walpole, Ronald E. (1995). Pengantar Statistika. Jakarta : PT. Gramedia Pustaka Utama.

Yitnosumarto, Suntoyo. (1990). Dasar-Dasar Statistika. Jakarta: Rajawali Pers. 
Halaman Ini Sengaja Dikosongkan 


\section{BAB 6 \\ DISTRIBUSI NORMAL}

\subsection{Pendahuluan}

Distribusi Normal adalah distribusi dari variabel acak kontinyu yang paling sering digunakan karena distribusi normal adalah distribusi yang paling luas aplikasinya dan merupakan pendekatan yang baik dari distribusi-distribusi lainnya.

Menurut Walpole dan Myers (1986), variabel acak X dikatakan berdistribusi normal umum, jika fungsi peluang untuk $\mathrm{X}$ diyatakan sebagaimana persamaan 6.1 sebagai berikut :

$$
f(x)=\frac{1}{\sqrt{2 \pi \sigma^{2}}} \exp \left[-\frac{1}{2 \sigma^{2}}(x-\mu)^{2}\right] ;-\infty<x<\infty,-\infty<\mu<\infty, \sigma^{2}>0
$$

Penulisan notasi dari variabel acak yang berdistribusi normal adalah $\mathrm{N}\left(x ; \mu, \sigma^{2}\right)$, yang memiliki arti bahwa variabel acak $\mathrm{x}$ memiliki distribusi normal dengan rata-rata $\mu$ dan ragam (variance) $\sigma^{2}$. Variabel acak $\mathrm{X}$ yang berdistribusi normal dengan rata-rata $\mu$ dan varians (ragam) $\sigma^{2} \cdot$ Juga dapat 
dituliskan sebagai $X \sim N I D\left(\mu, \sigma^{2}\right)$, NID berarti normally independently distributed. Kurva distribusi normal berbentuk lonceng atau genta yang ditunjukkan sebagaimana gambar 6.1 sebagai berikut :

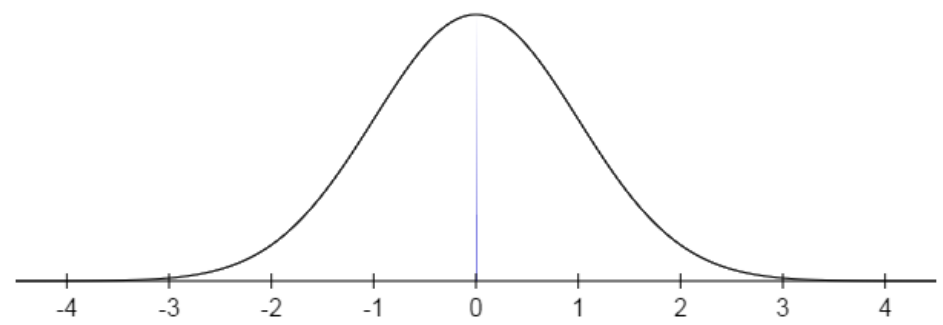

Gambar 6.1 Kurva Distribusi Normal

\subsection{Sifat-sifat Distribusi Normal}

a. Kurva distribusi normal berbentuk lonceng (genta)

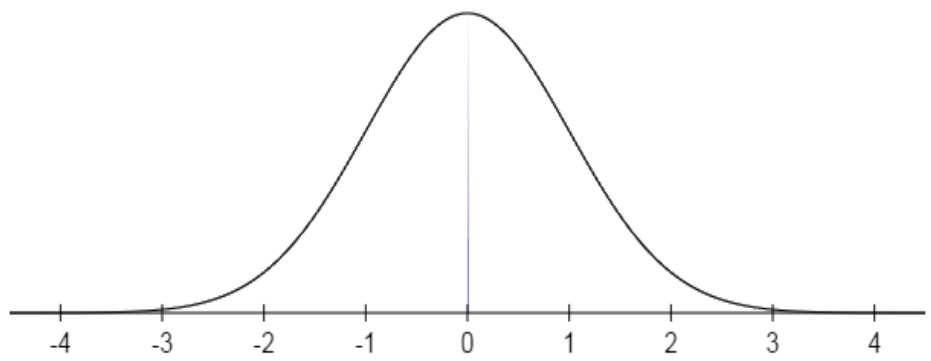

Seperti yang sudah di jelaskan pada bagian awal bahwa kurva distribusi normal berbentuk 
lonceng atau genta dengan dua paremeter yaitu $\mu$ (rata-rata) dan $\sigma$ (simpangan baku)

b. Kurva distribusi normal berbentuk lonceng (genta) mempunyai sifat setangkup

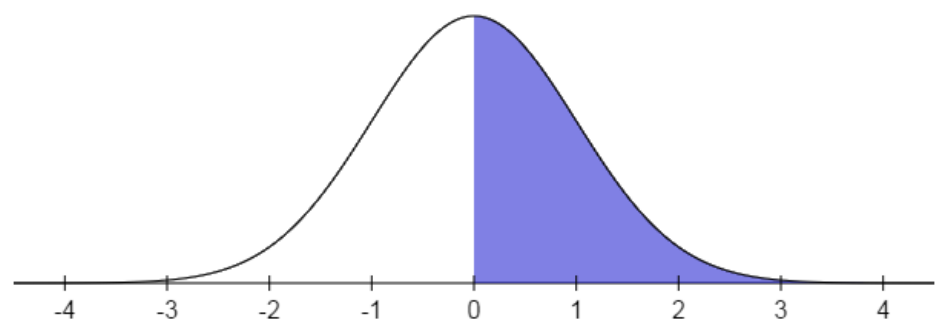

Sifat setangkup pada distribusi normal berarti bahwa luasan kurva distribusi normal sisi kiri sama dengan luasan kurva distribusi normal sisi kanan. Luas kurva ditribusi normal sisi kiri dan sisi kanan yaitu 0,5 .

c. Luas daerah yang terletak di bawah kurva tetapi di atas sumbu mendatar $\mathrm{x}$ sama dengan 1 atau dapat dinyatakan sebagai berikut:

$$
\int_{-\infty}^{\infty} f(x) d x=1
$$


Berdasarkan sifat setangkup distribusi normal, diketahui bahwa luas kurva ditribusi normal sisi kiri dan sisi kanan yaitu 0,5, sehingga luas kurva normal secara keseluruhan adalah 1.

d. Fungsi peluang distribusi normal mencapai maksimum di $x=\mu$, sehingga fungsi peluang ditribusi normal dapat dinyatakan sebagai berikut :

$$
f(x)=\frac{1}{\sqrt{2 \pi \sigma^{2}}}
$$

(Yitnosumarto,1990)

\subsection{Penggunaan Distribusi Normal}

Berikut ini diberikan contoh kasus penggunaan distribusi normal pada perhitungan-perhitungan nilai peluang untuk lebih mengetahui aplikasi dari distribusi normal yang dijelaskan.

Tinggi laki-laki dikelas tersebar secara normal dengan rata-rata $155 \mathrm{~cm}$ dan simpangan baku $7 \mathrm{~cm}$. Apabila di panggil secara acak, seorang laki-laki dikelas maka tentukan berapa peluang:

a. Tinggi laki-laki tersebut kurang dari $150 \mathrm{~cm}$

b. Tinggi laki-laki tersebut lebih dari $170 \mathrm{~cm}$ 


\section{c. Tinggi laki-laki tersebut antara $140-160 \mathrm{~cm}$ \\ d. Tinggi laki-laki tersebut tepat $160 \mathrm{~cm}$}

Untuk menyelesaikan kasus tersebut, kita misalkan bahwa tinggi badan laki-laki dikelas sebagai variabel acak X, sehingga notasi variabel acak $\mathrm{X}$ dapat dituliskan sebagai berikut :

$$
X \sim N I D(155,49)
$$

Karena luas daerah di bawah kurva fungsi peluang distribusi normal merupakan peluang maka nilai peluang untuk tinggi laki-laki dikelas adalah :

a. Tinggi laki-laki tersebut kurang dari $150 \mathrm{~cm}$

$$
\begin{aligned}
P(x<150)= & \int_{-\infty}^{150} f(x) d x \\
& =\int_{-\infty}^{150} \frac{1}{\sqrt{2 \pi(49)}} \exp \left[-\frac{1}{2(49)}(x-155)^{2}\right] d x
\end{aligned}
$$

b. Tinggi laki-laki tersebut lebih dari $170 \mathrm{~cm}$

$$
\begin{aligned}
P(x>170)= & \int_{170}^{\infty} f(x) d x \\
& =\int_{170}^{\infty} \frac{1}{\sqrt{2 \pi(49)}} \exp \left[-\frac{1}{2(49)}(x-155)^{2}\right] d x
\end{aligned}
$$


c. Tinggi laki-laki tersebut antara $140-160 \mathrm{~cm}$

$$
\begin{aligned}
P(140<x<160) & =\int_{140}^{160} f(x) d x \\
= & \int_{140}^{160} \frac{1}{\sqrt{2 \pi(49)}} \exp \left[-\frac{1}{2(49)}(x-155)^{2}\right] d x
\end{aligned}
$$

d. Tinggi laki-laki tersebut tepat $160 \mathrm{~cm}$

Karena nilai peluang merupakan luas daerah di bawah kurva fungsi peluang distribusi normal maka peluang untuk $\mathrm{P}(\mathrm{X}=160)$ tidak dapat dihitung, sehingga kita harus menempatkan diantara dua nilai misalnya antara 159,95 $\mathrm{cm}$ dan 160,05 $\mathrm{cm}$. Jadi peluang untuk tinggi laki-laki tepat 160 adalah:

$$
\begin{aligned}
P(159,95<x<160,05) & =\int_{159,95}^{160,05} f(x) d x \\
& =\int_{159,95}^{160,05} \frac{1}{\sqrt{2 \pi(49)}} \exp \left[-\frac{1}{2(49)}(x-155)^{2}\right] d x
\end{aligned}
$$

\subsection{Transformasi Distribusi Normal}

Proses penyelesaian integral fungsi peluang distribusi normal cukup rumit oleh karena itu, untuk mempermudah proses penyelesaian terdapat transformasi dari distribusi normal ke distribusi normal baku. Menurut Yitnosumarto 
(1990), bentuk tranformasi distribusi normal baku dinyatakan sebagaimana persamaan 6.2 sebagai berikut:

$$
Z=\frac{X-\mu}{\sigma}
$$

di mana :

$\mu=$ rata-rata

$\sigma=$ simpangan baku

Distribusi normal baku adalah distribusi untuk variabel acak normal dengan nilai tengah nol dan simpangan baku 1. Fungsi peluang distribusi normal baku dinyatakan sebagaimana

$$
f(x)=\frac{1}{\sqrt{2 \pi}} \exp \left[-\frac{1}{2} x^{2}\right] ;-\infty<x<\infty
$$

Untuk lebih memahami proses transformasi distribusi normal baku, berikut ini diberikan contoh kasus penggunaan 
transformasi normal baku menggunakan contoh kasus yang sama dengan distribusi normal umum sebagai berikut.

Tinggi laki-laki dewasa di Indonesia tersebar secara normal dengan rata-rata $155 \mathrm{~cm}$ dan ragam $7 \mathrm{~cm}$. Apabila di panggil secara acak, seorang laki-laki dewasa Indonesia, berapa peluang :

a. Tinggi orang tersebut kurang dari $150 \mathrm{~cm}$

b. Tinggi orang tersebut lebih dari $170 \mathrm{~cm}$

c. Tinggi orang tersebut antara $140-160 \mathrm{~cm}$

d. Tinggi laki-laki tersebut tepat $160 \mathrm{~cm}$

Dengan menggunakan transformasi normal baku, maka nilai peluang untuk tinggi laki-laki dikelas adalah sebagai berikut :

a. Tinggi orang tersebut kurang dari $150 \mathrm{~cm}$

$$
\begin{aligned}
\operatorname{a.P(x<150)} & =P\left(Z<\frac{150-155}{7}\right) \\
& =P(Z<-0,71) \\
& =P(Z>0,71) \\
& =P(Z>0)-P(0<Z<0,71) \\
& =0,5-0,2612 \\
& =0,2388
\end{aligned}
$$


b. Tinggi orang tersebut lebih dari $170 \mathrm{~cm}$

$$
\begin{aligned}
P(x>170) & =P\left(Z>\frac{170-155}{7}\right) \\
& =P(Z>2,14) \\
& =P(Z>0)-P(0<Z<2,14) \\
& =0,5-0,4838 \\
& =0,0162
\end{aligned}
$$

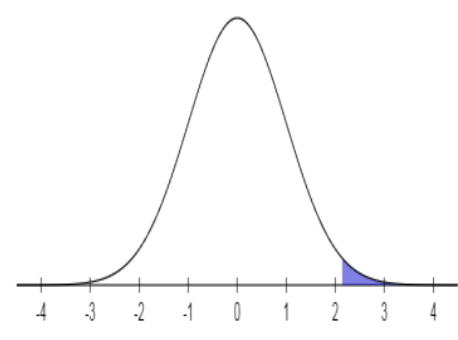

c. Tinggi orang tersebut antara $140-160 \mathrm{~cm}$

$$
\begin{aligned}
P(140<x<160) & =P\left(\frac{140-155}{7}<Z<\frac{160-155}{7}\right) \\
& =P(-2,14<Z<0,71) \\
& =P(-2,14<Z<0)+P(0<Z<0,71) \\
& =0,4838+0,2612=0,745
\end{aligned}
$$

d.Tinggi laki-laki tersebut tepat $160 \mathrm{~cm}$

Sama halnya dengan distribusi normal umum peluang untuk $\mathrm{P}(\mathrm{X}=160)$ tidak dapat dihitung, sehingga kita harus menempatkan diantara dua nilai misalnya antara 159,95 $\mathrm{cm}$ dan 160,05 cm. Jadi peluang untuk tinggi laki-laki tepat 160 adalah 


$$
\begin{aligned}
& P(159,95<x<160,05) \\
& =P\left(\frac{159,95-155}{7}<Z<\frac{160,05-155}{7}\right) \\
& =P(0,71<Z<0,72) \\
& =P(Z>0)-P(0<Z<0,71)-P(Z>0,72) \\
& =P(Z>0)-P(0<Z<0,71)-(P(Z>0)-P(0<Z<0,72)) \\
& =0,5-0,2612-(0,5-0,2642) \\
& =0,5-0,2612-0,2358 \\
& =0,003
\end{aligned}
$$

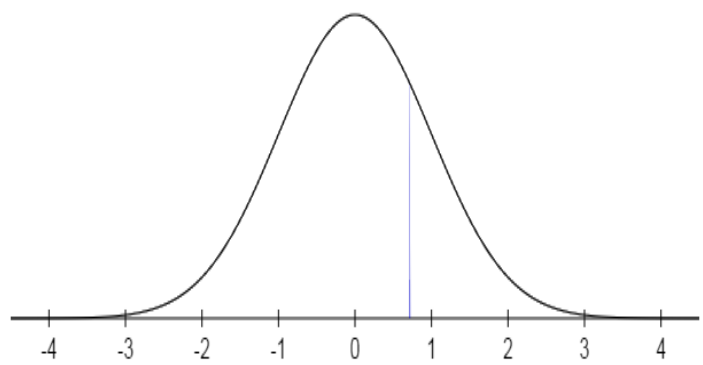




\subsection{Rangkuman}

- Distribusi Normal adalah distribusi dari variabel acak kontinyu yang paling luas aplikasinya dan merupakan pendekatan yang baik dari distribusi-distribusi lainnya.

- Fungsi peluang distribusi normal umum dinyatakan sebagaimana persamaan sebagai berikut :

$$
f(x)=\frac{1}{\sqrt{2 \pi \sigma^{2}}} \exp \left[-\frac{1}{2 \sigma^{2}}(x-\mu)^{2}\right] ;-\infty<x<\infty,-\infty<\mu<\infty, \sigma^{2}>0
$$

Notasi variabel acak X yang beristribusi normal dapat dinyatakan sebagai

- Bentuk transformasi distribusi normal baku adalah sebagai berikut :

$$
Z=\frac{X-\mu}{\sigma}
$$

- Fungsi peluang distribusi normal baku dinyatakan sebagaimana persamaan sebagai berikut :

$$
f(x)=\frac{1}{\sqrt{2 \pi}} \exp \left[-\frac{1}{2} x^{2}\right] ;-\infty<x<\infty
$$


Distribusi normal baku adalah distribusi untuk variabel acak normal dengan nilai tengah nol dan simpangan baku 1.

\subsection{Latihan}

1. Berat badan mahasiswa Fakultas Ekonomi dan Bisnis Universitas Muhammadiyah Sidoarjo tersebar secara normal dengan rata-rata $55 \mathrm{~kg}$ dan ragam $6 \mathrm{~kg}$. Apabila diamati secara acak, seorang mahasiswa FEB UMSIDA, tentukan berapa peluang :

a. Berat badan mahasiswa tersebut kurang dari $50 \mathrm{~cm}$

b. Berat badan mahasiswa tersebut lebih dari $62 \mathrm{~cm}$

c. Tinggi orang tersebut antara $53-64 \mathrm{~cm}$

d. Tinggi laki-laki tersebut tepat $57 \mathrm{~cm}$

2. Dengan menggunakan tabel distribusi normal baku tentukan nilai peluang :
a. Nilai Z lebih besar dari 1,65
b. Nilai $Z$ diantara $-1,65$ sampai 2,04
c. Nilai $Z$ kurang dari 1,43
d. Nilai $Z$ diantara 1,75 sampai 2,45

3. Nilai UAS matakuliah statistika dasar mahasiswa FKIP UMSIDA tersebar secara normal dengan rata-rata 83 dan 
ragam $5 \mathrm{~kg}$. Apabila diamati secara acak, tentukan berapa peluang :

a. Nilai UAS mahasiswa kurang dari 75

b. Nilai UAS mahasiswa kurang dari 90

c. Nilai UAS mahasiswa diantara 78 sampai 87

d. Nilai UAS mahasiswa lebih dari 79

\section{Daftar Pustaka}

Walpole, R. E., \& Myers, R. H. (1986). Ilmu peluang dan Statistika untuk Insinyur dan Ilmuwan (R. K. Sembiring, Trans.). Bandung: Penerbit ITB.

Yitnosumarto, Suntoyo. (1990). Dasar-Dasar Statistika. Jakarta: Rajawali Pers. 
Halaman ini sengaja dikosongkan 


\section{BAB 7 \\ HIPOTESA}

\subsection{Pendahuluan}

Hipotesa statistik merupakan suatu pernyataan probabilitas dari satu atau lebih parameter populasi yang mungkin benar atau mungkin salah (wibisono, 2009). Hipotesa adalah asumsi atau dugaan mengenai sesuatu hal yang dibuat untuk menjelaskan hal itu yang sering dituntut untuk melakukan pengecekan. Hipotesa statistik adalah suatu anggapan atau pernyataan yang mungkin benar atau tidak mengenai satu populasi atau lebih. Langkah atau prosedur untuk menentukan apakah menerima atau menolak hipotesis disebut Pengujian Hipotesis. Hipotesis Nol menyatakan setiap hipotesis yang ingin diuji dinyatakan dengan H0. Hipotesis Tandingan merupakan penolakan terhadap H0, dinyatakan dengan $\mathrm{H} 1$.

Langkah-langkah penulisan hipotesis yang biasa dilakukan adalah merumuskan hipotesis yang akan ditulis disertai keterangan seperlunya. Terdapat tiga macam parameter, yaitu: 
1. Hipotesis mengandung Pengertian Minimum Misalkan:

Salah satu pabrik lampu menyatakan bahwa masa pakai lampu tidak kurang dari 2 tahun. Pernyataan pabrik harus ditolak jika rata-rata umur pakai lampu kurang dari 2 tahun dan harus diterima jika umur pakai lampu lebih lama atau sama dengan 2 tahun. Perumusan hipotesa yang digunakan adalah:

Ho : $\mu=2$ tahun ; berarti masa pakai lampu tidak kurang dari 2 tahun.

H1 $: \mu<2$ tahun; berarti masa pakai lampu kurang dari 2 tahun.

2. Hipotesis mengandung Pengertian Maksimum Misalkan :

Perusahaan rokok menyatakan bahwa kandungan tar per bungkus tidak lebih dari $0,1 \mathrm{mg}$. Pernyataan perusahaan ini harus ditolak jika kandungan tar melebihi 0,1 mg, dan harus menerima jika kandungan tar lebih kecil atau sama denga 0,1 mg. Perumusan yang digunakan adalah:

Ho : $\mu=0,1 \mathrm{mg}$; kandungan tar per bungkus rokok maksimum $0.1 \mathrm{mg}$. 
$\mathrm{H} 1: \mu>2$ tahun; kandungan tar per bungkus rokok lebih dari $0.1 \mathrm{mg}$.

3. Hipotesis mengandung Pengertian Sama

Misalkan :

Jika kita ingin menguji dugaan sales penjualan suku cadang yang menyatakan baha persentase penjualan suku cadang naik sebesar $30 \%$ pada tahun 2015 . Perumusan yang digunakan adalah:

Ho : $\mu=30 \%$; berarti hanya sekitar $30 \%$ untuk tahun 2015 penjualan suku cadang.

$\mathrm{H} 1: \mu \neq 30 \%$; berarti penjualan suku cadang tidaklah $30 \%$ untuk tahun 2015.

\subsection{Dua Jenis Kesalahan Hipotesa}

Dalam melakukan pengujian hipotesis, ada dua macam kekeliruan yang terjadi, yaitu :

Tabel 7.1 Kekeliruan Hipotesa

\begin{tabular}{l|l|l}
\hline & & \\
\hline Terima Ho & Keputusan Benar & Kekeliruan (Galat II) \\
\hline Tolak Ho & Kekeliruan (Galat I) & Keputusan Benar \\
\hline
\end{tabular}


1. Kekeliruan (Galat) I yaitu menolak hipotesis yang seharusnya diterima disebut juga kekeliruan $\alpha$.

2. Kekeliruan (Galat) II yaitu menerima hipotesis yang seharusnya ditolak disebut juga kekeliruan $\beta$.

\subsection{Langkah-langkah pengujian hipotesa}

1. Rumuskan Ho yg sesuai

2. Rumuskan hipotesis tandingannya (H1) yg sesuai

3. Pilih taraf nyata pengujian sebesar $\alpha$

4. Pilih uji statistik yg sesuai dan tentukan daerah kritisnya

5. Hitung nilai statistik dari contoh acak berukuran $n$

6. Buat keputusan: tolak Ho jika statistik mempunyai nilai dalam daerah kritis, selain itu terima Ho.

\subsection{Pengujian Hipotesa}

\subsubsection{Menguji Rataan $\boldsymbol{\mu}$ : Uji Dua Pihak}

Jika kita mempunyai sebuah populasi berdistribusi normal dengan rata-rata $\mu$ dan simpangan baku $\sigma$. Akan diuji mengenai parameter rataan $\mu$. Untuk hal ini , seperti biasa diambil sebuah sampel acak berukuran $\mathrm{n}$, lalu hitung statistik x-bar dan s. Maka dapat dibedakan hal-hal berikut :

\section{Jika $\sigma$ Diketahui}


Untuk pasangan hipotesisnya :

$$
\begin{aligned}
& \text { Ho }: \mu=\mu \mathrm{o} \\
& \text { H1 }: \mu \neq \mu \mathrm{o}
\end{aligned}
$$

dengan $\mu$ o sebuah harga yang diketahui, digunakan statistik :

$$
Z=\frac{X-\mu o}{\sigma / \sqrt{n}}
$$

\section{Jika $\sigma$ Tidak Diketahui}

Pada kenyataannya simpangan baku $\sigma$ sering tidak diketahui. Dalam hal ini maka diambil taksirannya ialah simpangan baku s yang dihitung dari sampel dengan menggunakan rumus :

$$
S^{2}=\frac{\sum\left(X_{i}-X\right)^{2}}{n-1}
$$

Sehingga, statistika yang digunakan untuk menguji pasangan hipotesis :

$$
\text { Ho }: \mu=\mu \mathrm{o}
$$


H1 : $\mu \neq \mu \mathrm{o}$, sehingga rumus yang dipakai adalah :

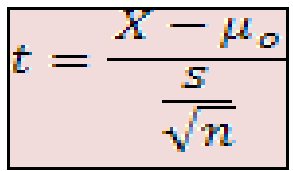

\subsubsection{Menguji Rataan $\mu$ : Uji Satu Pihak}

Secara resmi uji hipotesis mengenai satu rataan populasi. Perumusan yang umum untuk uji satu pihak kanan mengenai rata-rata $\mu$ berdasarkan Ho dan $\mathrm{H} 1$ adalah

$$
\begin{aligned}
& \text { Ho }: \mu=\mu \mathrm{o} \\
& \text { H1 }: \mu>\mu \mathrm{o}
\end{aligned}
$$

Di misalkan populasi berdistribusi normal dengan sampel acak berukuran $n$ telah diambil. Seperti biasa dari sampel dihitung X-bar dan S.

\section{Jika $\sigma$ Diketahui}

Jika simpangan baku $\boldsymbol{\sigma}$ untuk populasi diketahui, seperti biasa digunakan statistik $\mathrm{Z}$ dengan rumus :

$$
Z=\frac{X-\mu o}{\sigma / \sqrt{n}}
$$


Kita tolak Ho jika $Z \geq Z_{0,5-\alpha}$ dengan $Z_{0,5-\alpha}$ didapat dari daftar normal baku menggunakan peluang $(0,5-\alpha)$. Dalam hal lainnya Ho kita terima.

\section{Jika $\sigma$ Tidak Diketahui}

Jika $\sigma$ tidak diketahui, statistik yang digunakan untuk menguji :

$$
\begin{aligned}
& \text { Ho }: \mu=\mu \mathrm{o} \\
& \text { H1 }: \mu>\mu \mathrm{o}
\end{aligned}
$$

Dengan menggunakan statistik distribusi-t yaitu :

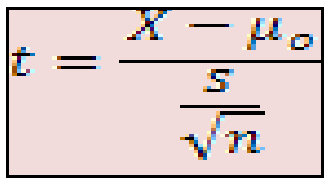

(7.5)

Kriteria pengujian di dapat dari daftar distribusi student-t dengan $\mathrm{dk}=(\mathrm{n}-1)$ dan peluang $(1-\alpha)$. Jadi kita tolak Ho jika $t \geq t_{1-\alpha}$ dan terima Ho dalam hal lain.

\subsubsection{Menguji Proporsi $\mu$ : Uji Dua Pihak}

Misalkan, kita mempunyai populasi binom dengan proporsi berukuran $\mathrm{A}=\pi$. Berdasarkan sebuah sampel acak yang diambil dari populasi itu, akan diuji mengenai uji dua pihak.

$$
\text { Ho }: \pi=\pi \mathrm{o}
$$




$$
\mathrm{H} 1: \pi \neq \pi \mathrm{o}
$$

dengan $\pi$ o sebuah harga yang diketahui. Dari sampel berukuran $\mathrm{n}$ itu kita hitung proporsi sampel $\mathrm{x} / \mathrm{n}$ adanya peristiwa A. Dengan menggunakan distribusi normal, maka untuk pengujian ini digunakan statistik $\mathrm{z}$ dengan rumus :

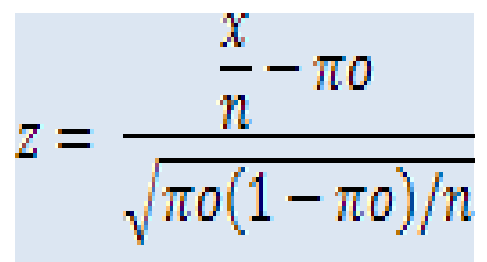

Kriteria untuk pengujian ini, dengan taraf nyata $\alpha$

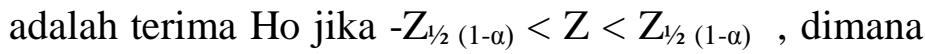
$\mathrm{Z}_{1 / 2}$ (1-a) didapat dari daftar normal baku dengan peluang $1 / 2(1-\alpha)$. Dalam hal lainnya, hipotesis Ho ditolak.

\subsubsection{Menguji Proporsi $\boldsymbol{\mu}$ : Uji Satu Pihak}

Jika yang diuji dari populasi binom itu berbentuk :

Ho : $\Pi=\Pi о$

$\mathrm{H} 1: \Pi>\Pi \circ$

Maka penguan demikian merupakan uji pihak kanan. Rumus yang digunakan adalah 


$$
z=\frac{\frac{x}{n}-\pi o}{\sqrt{\pi o(1-\pi o) / n}}
$$

Yang berbeda adalah dalam penentuan kriteria pengujiannya. Dalam hal ini tolak Ho jika $\mathrm{Z} \geq \mathrm{Z}_{0,5-\alpha}$ dimana $\mathrm{Z}_{0,5-\alpha}$ didapat dari daftar normal baku dengan peluang $(0,5-\alpha)$ Untuk Hipotesis $\mathrm{Z}<\mathrm{Z}_{0,5-\alpha}$ hipotesis Ho diterima.

\subsection{Contoh Soal}

1. Uji rataan $\mu$ : Uji Dua Pihak, dengan nilai $\sigma$ diketahui Pengusaha lampu pijar A mengatakan bahwa lampunya bisa tahan pakai sekitar 800 jam. Akhirakhir ini timbul dugaan bahwa masa pakai lampu itu telah berubah. Untuk menentukan hal ini, dilakukan penelitian dengan jalan menguji 50 lampu. Ternyata rata-ratanya 792 jam. Dari pengalaman, diketahui bahwa simpangan baku masa hidup lampu 60 jam. Selidikilah dengan taraf nyata 0,05 apakah kualitas lampu itu sudah berubah atau belum.

Jawab :
a. $\bar{X}=792$
b. $\mathrm{n}=50$ 
c. $\mu \mathrm{o}=800$

d. $\sigma=60$

e. Jadi,

$$
Z=\frac{792-800}{60 \sqrt{50}}=-0,94
$$

f. Sehingga dari daftar normal baku untuk uji dua pihak dengan taraf keberartian 0,05 yang memberikan $\mathrm{Z}_{0,475}=1,96$.

g. Kesimpulan : Terima Ho jika z hitung terletak antara $-1,96$ dan 1,96 .

2. Uji rataan $\mu$ : Uji Dua Pihak, dengan nilai $\sigma$ tidak diketahui

Suatu alat penyedot debu menggunakan rata-rata 46 kilowatt-jam per tahun. Bila sampel acak 12 rumah yang diikut sertakan dalam rancangan penelitian dan menunjukkan bahwa penyedot debu menggunakan rata-rata 42 kilowatt-jam per tahun dengan simpangan baku 11,9 kilowatt-jam, apakah ini menunjukkan pada taraf keberartian 0,05 bahwa penyedot debu menggunakan, pada rata-rata kurang dari 46 kilowattjam setahun? Anggap bahwa populasi kilowatt-jam berdistribusi normal!. 
Jawab :

a. Ho : $\mu=46$ kilowatt-jam

b. H1 : $\mu<46$ kilowatt-jam

c. $\alpha=0,05 ; \mathrm{N}=12$ dengan $\mathrm{v}=11$ derajat kebebasan $(\mathrm{V}=\mathrm{n}-1=12-1=11)=-1,796$

d. Perhitungan ; $\bar{X}=42$ kilowatt-jam, $\sigma=11,9$ kilowatt-jam, sehingga

$$
\begin{aligned}
t & =\frac{\bar{X}-\mu}{s / \sqrt{n}} \\
t=\frac{42-46}{11,9 / \sqrt{12}} & =-1,16
\end{aligned}
$$

e. Keputusan : Terima Ho dan dapat disimpulkan bahwa rata-rata banyaknya penggunaan kilowatt-jam setahun penyedot debu di rumah tidak berbeda secara berarti dengan 46 .

3. Uji rataan $\mu$ : Uji Satu Pihak, dengan nilai $\sigma$ diketahui Sampel acak catatan 100 kematian di AS selama setahn lalu menunjukkan rata-rata usia mereka 71,8 tahun. Andaikan sempangan bakunya 8,9 tahun, apakah ini menunjukkan bahwa rata-rata usia ini lebih dari 70 tahun. Dengan taraf keberartian 0,05.

Jawab

1. Ho : $\mu=70$ tahun 
2. H1 $: \mu>70$ tahun

3. $\alpha=0,05$

4. Daerah kritis z > 1,645 bila

5. Perhitungan ; $\bar{X}=71,8$ tahun, $\sigma=8,9$ tahun, sehingga

$Z=\frac{X-\mu 0}{\sigma / \sqrt{n}} \rightarrow Z=\frac{71,8-70}{8,9 / \sqrt{100}}=2,02$

6. Keputusan : Tolak Ho dan dapat disimpulkan bahwa rata-rata usia melebihi 70 tahun.

7.Dengan menggunakan tabel L.3, maka diperoleh :

$\mathrm{P}=\mathrm{P}(\mathrm{Z}>2,02)=0,0217$, hasil lebih kuat daripada yang ditunjukkan oleh taraf keberartian 0,05

4. Uji rataan $\mu$ : Uji Satu Pihak, dengan nilai $\sigma$ tidak diketahui

Dikatakan bahwa dengan menyuntikkan semacam hormon tertentu kepada ayam akan menambah berat telurnya rata-rata dengan 4,5 gram. Sampel acak terdiri atas 31 butir telur dari ayam yang telah diberika suntikan hormon tersebut memberikan rata-rata berat 4,9 gram dan simpangan baku $\mathrm{s}=0,8$ gram. Cukup beralasankah untuk menerima pernyataan bahwa 
pertambahan rata-rata berat telur paling sedikit 4,5 gram. Dengan taraf keberartian $=0,01$.

Jawab :

a. Ho : $\mu=4,5$ gram

b. H1 : $\mu>4,5$ gram

c. $\bar{X}=4,9$ gram; $\mathrm{s}=0,8$ gram; $\mathrm{n}=31, \mathrm{~V}=30$, sehingga nilai $\mathrm{t}$ tabel dengan $\mathrm{v}=30, \alpha=0,01$ dengan $\mathrm{t}$ tabel $=2,326$

d. Sehingga :

$$
t=\frac{4,9-4,5}{0,8 / \sqrt{31}}=2,78
$$

e. Kesimpulan tolak hipotesis Ho jika t hitung lebih besar atau sama dengan 2,326.

5. Uji Proporsi : Uji Dua Pihak

"Kita ingin menguji bahwa distribusi jenis kelamin laki-laki dan perempuan adalah sama. Sebuah sampel acak terdiri atas 4.800 orang mengandung 2.458 lakilaki. Dalam taraf nyata 0,05 betulkan distribusi kedua jenis kelamin itu sama.

Jawab : 
a. Jika $\pi=$ peluang terdapatnya laki-laki, maka akan dapat diuji pasangan hipotesis :

$$
\begin{aligned}
& \text { Ho : } \pi=1 / 2 \\
& \text { H1 }: \pi \neq 1 / 2
\end{aligned}
$$

b. $x=2.458 ; n=4.800, \pi 0=1 / 2$, sehingga :

$$
\begin{aligned}
& z=\frac{\frac{x}{n}-\pi o}{\sqrt{\pi o(1-\pi o) / n}} \\
& z=\frac{\frac{2.458}{4.800}-0,5}{\sqrt{0,5(0,5) / 4800}}=1,68
\end{aligned}
$$

c. Angka $\mathrm{Z}$ dari daftar normal baku dengan $\alpha=0,05$ adalah 1,96. Sehingga kesimpulannya adalah Terima Ho jika $\mathrm{Z}$ hitung terletak antara -1,96 dan 1,96, sedangkan dalam hal lainnya Ho ditolak. Karena nilai $\mathrm{Z}$ berada pada daerah penerimaan Ho sehingga Ho diterima. Sehingga, peluang adanya laki-laki dan perempuan sama besar.

6. Uji Proporsi : Uji Satu Pihak

Seorang pejabat mengatakan bahwa paling banyak 60 $\%$ anggota masyarakat termasuk golongan A. Sebuah 
sampel acak telah diambil yang terdiri atas 8.500 orang dan ternyata 5.426 termasuk golongan A. Apabila $\alpha=0,01$ benarkah pernyataan tersebut ?

Jawab :

a. Menyusun Hipotesa:

$$
\begin{aligned}
& \text { Ho }: \Pi=0,6 \\
& \text { H1 } \Pi>0,6 \\
& \text { b. } \mathrm{x}=5.426 ; \pi=0,6 \\
& \text { c. } \mathrm{n}=8.500 ;(1-\pi)=0,4 \text {, Sehingga di dapatkan : } \\
& Z=\frac{\frac{x}{n}-\pi 0}{\sqrt{\pi 0(1-\pi 0) / n}} \\
& z=\frac{5.426}{\sqrt{0,500}-0,6(0,4) / 8500}=2,79 \\
& \text { Dengan taraf nyata } \alpha=0,01 \text { dari daftar normal baku } \\
& \text { memberikan } \mathrm{Z} 0,49=2,33 . \text { Harga } \mathrm{Z} \text { hitung }=2,79 \text { lebih } \\
& \text { besar dari } \mathrm{Z} \text { daftar }=2,33 . \text { Maka, Tolak Ho dan uji } \\
& \text { sangat berarti, ini menunjukkan bahwa masyarakat } \\
& \text { golongan A sudah melampaui } 60 \%
\end{aligned}
$$




\subsection{Rangkuman}

Hipotesa statistik merupakan suatu pernyataan probabilitas dari satu atau lebih parameter populasi yang mungkin benar atau mungkin salah.

* Terdapat dua jenis hipotesis, yaitu Hipotesis awal (Ho) dan Hipotesis alternatif (H1).

* Terdapat tiga parameter dalam penulisan hipotesis, yaitu:

1. Hipotesis yang mengandung pengertian minimum

2. Hipotesis yang mengandung pengertian maksimum

3. Hipotesis yang mengenadung pengertian sama.

* Pengujian hipotesis antara lain:

1. Menguji Rataan : Uji Dua Pihak

2. Menguji Rataan : Uji Satu Pihak

3. Menguji Proporsi : Uji Dua Pihak

4. Menguji Proporsi : Uji Satu Pihak 


\subsection{Latihan}

1. Menurut majalah kesehatan, sebuah perusahaan memperkenalkan obat jenis baru yang dapat menurunkan tekanan darah sebesar 18,5 mmHg. Seorang dokter tengah mengamati 25 orang pasien penderita hipertensi dan diberi obat baru tersebut. Setelah seminggu diperoleh informasi bahwa rata-rata tekanan darah penderita hipertensi menurun sebesar $20 \mathrm{mmHg}$ dan simpangan baku $35 \mathrm{mmHg}$. Taksirlah dengan taraf nyata $5 \%$, apakah pemberian obat jenis baru dapat menurunkan tekanan darah pasien.

2. Sebuah perusahaan kue kering menuliskan berat bersih dalam toplesnya sebesar 250 gr. Apakah betul berat bersih kue kering adalah 250 gr atau tidak. Untuk itu dilakukan penelitian terhadap 20 toples, isinya dibuka dan ditimbang. Dari hasil penimbangan 20 kemasan, diperoleh rata-rata 247 gr dengan simpangan baku 5 gr. Apakah hasil penelitian menunjukkan bahwa berat bersih kue kering tersebut $250 \mathrm{gr}$, dengan taraf nyata $10 \%$. 


\section{Daftar Pustaka}

Walpole, R. E., \& Myers, R. H. (1986). Ilmu peluang dan

Statistika untuk Insinyur dan Ilmuwan (R. K.

Sembiring, Trans.). Bandung: Penerbit ITB.

Wibisono, Yusuf (2009)., Metode Statistik. Yogyakarta:

Gadjah Mada Press 
Halaman Ini Sengaja Dikosongkan 


\section{BAB 8}

\section{REGRESI DAN KORELASI}

\subsection{Pendahuluan}

Analisis regresi dapat didefinisikan sebagai metode statistika yang digunakan untuk mengetahui hubungan fungsional linear antara satu variabel respon dengan satu variabel prediktor. Sedangkan analisis korelasi dapat didefinisikan sebagai analisis yang digunakan untuk mengukur keeratan hubungan antara dua variabel. Kata variabel didefinisikan sebagai karakteristik dari objek yang diteliti. Terdapat dua jenis variabel dalam analisis regresi yaitu variabel respon atau disebut dengan variabel dependen (Y) dan variabel prediktor atau disebut variabel independen (X). Variabel respon (Y) dinyatakan juga sebagai variabel yang dipengaruhi dan variabel prediktor $(\mathrm{X})$ dinyatakan juga sebagai variabel yang mempengaruhi. Terdapat dua jenis analisis regresi linier yaitu analisis regresi linier sederhana dan analisis regresi linier berganda. Analisis regresi linier sederhana hanya melibatkan satu variabel prediktor sedangkan analisis regresi linier berganda melibatkan dua atau lebih variabel prediktor. 
Regresi linear berarti bahwa variabel respon (Y) berkaitan linear dengan variabel prediktor (X) dalam bentuk persamaan linearyang dapat dinyatakan sebagaimana persamaan 8.1 sebagai berikut :

$$
Y=\alpha+\beta x
$$

Dimana, $\alpha$ dan $\beta$ adalah dua parameter pada analisis regresi yang disebut sebagai intercept $(\alpha)$ dan slope $(\beta)$ (Walpole dan Myers, 1986).

Berbeda dengan analisis regresi, analisis korelasi hanya digunakan untuk mengetahui keeratan hubungan antara dua variabel, tanpa memperhatikan variabel yang dipengaruhi dan variabel yang mempengaruhi. Besarnya keeratan hubungan dalam analisis korelasi dinyatakan menggunakan koefisien korelasi.

\subsection{Analisis Regresi Linier}

Hubungan fungsional linear yang hanya melibatkan satu variabel respon dengan satu variabel prediktor termasuk dalam analisis regresi linier sederhana. Persamaan analisis regresi linier sederhana telah dinyatakan pada persamaan 8.1 di atas. Dua parameter $\alpha$ dan $\beta$ dalam analisis regresi linier 
sederhana diduga dengan a dan b menggunakan data sampel, sehingga penduga untuk respon dinyatakan sebagaimana persamaan 8.2 sebagai berikut :

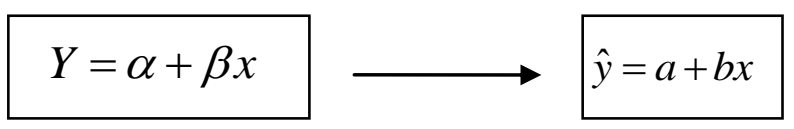

dimana :

$\mathrm{a}=$ intercept

$\mathrm{b}=$ slope

Pada analisis regresi intercept didefinisikan sebagai adalah rata-rata variabel respon $(\mathrm{Y})$ saat variabel prediktor (X) bernilai 0. Sedangkan slope didefinisikan sebagai nilai yang menunjukkan seberapa besar kontribusi atau pengaruh yang diberikan oleh suatu variabel predikor (X) terhadap variabel respon (Y) atau dapat diartikan sebagai rata-rata pertambahan atau pengurangan pada variabel $\mathrm{Y}$ untuk setiap peningkatan satu satuan variabel $\mathrm{X}$

Berbeda dengan analisis analisis regresi linier sederhana terdapat juga analisis regresi linier yang melibatkan lebih dari satu variabel predoktor (X) yang disebut sebagai analisis regresi linier berganda. Secara umum analisis regresi 
linier berganda dapat didefinisikan sebagai metode statistika yang digunakan untuk mengetahui hubungan fungsional linear antara satu variabel respon (Y) dengan dua atau lebih variabel prediktor (X). Menurut Walpole (1995), bentuk persamaan regresi linier berganda yang melibatkan dua variabel prediktor, tiga variabel prediktor dan $k$ buah variabel prediktor secara berurutan dinyatakan sebagaimana persamaan $8.3,8.4$ dan 8.5 sebagai berikut :

$$
\hat{y}=a+b_{1} x_{1}+b_{2} x_{2}
$$

$$
\hat{y}=a+b_{1} x_{1}+b_{2} x_{2}+b_{3} x_{3}
$$

$$
\hat{y}=a+b_{1} x_{1}+\ldots+b_{k} x_{k}
$$

\section{$\underline{\text { 8.2.1 Koefisien regresi linier sederhana dan berganda }}$}

Intercept (a) dan slope (b) pada analisis regresi linier disebut sebagai koefisien regresi. Persamaan untuk menghitung koefisien regresi linier sederhana berbeda dengan koefisien berganda. Berikut akan diuraikan persamaan untuk 
menghitung koefisien regresi linier sederhana berbeda dengan koefisien berganda.

\subsubsection{Koefisien regresi linier sederhana}

Menurut Walpole (1995), persamaan untuk menghitung nilai slope (b) dan intercept (a) secara berurutan dinyatakan

$$
b=\frac{n \sum_{i=1}^{n} x_{i} y_{i}-\left(\sum_{i=1}^{n} x_{i}\right)\left(\sum_{i=1}^{n} y_{i}\right)}{n \sum_{i=1}^{n} x_{i}^{2}-\left(\sum_{i=1}^{n} x_{i}\right)^{2}} \quad \text { agai berikut : }
$$

di mana :

$X=$ variabel prediktor

$\mathrm{Y}=$ variabel respon

$i=1,2,3, \ldots, n$

$n=$ jumlah data 


$$
a=\bar{y}-b \bar{x}
$$

di mana :

$\overline{\mathrm{X}}=$ rata-rata variabel prediktor

$\overline{\mathrm{y}}=$ rata-rata variabel respon

\subsubsection{Koefisien regresi linier berganda}

Menurut Walpole dan Myers (1986), persamaan untuk menghitung nilai slope (b) pada analisis regresi linier berganda yang melibatkan dua variabel prediktor dinyatakan sebagaimana persamaan 8.8 dan 8.9 sebagai berikut :

$$
b_{1}=\frac{\left(\sum x_{2}^{2} \sum x_{1} y\right)-\left(\sum x_{2} y \sum x_{1} x_{2}\right)}{\left(\sum x_{1}^{2} \sum x_{2}^{2}\right)-\left(\sum x_{1} x_{2}\right)^{2}}
$$

$$
b_{2}=\frac{\left(\sum x_{1}^{2} \sum x_{2} y\right)-\left(\sum x_{1} y \sum x_{1} x_{2}\right)}{\left(\sum x_{1}^{2} \sum x_{2}^{2}\right)-\left(\sum x_{1} x_{2}\right)^{2}}
$$


Komponen penyusun masing-masing perhitungan slope diuraikan pada beberapa persamaan di bawah ini, untuk lebih mempermudah proses perhitungan masing-masing komponen dimisalkan sebagai A, B, C, D, E dan F yang dinyatakan sebagaimana persamaan sebagai berikut :

$$
\begin{aligned}
& A=\sum x_{1}^{2}=\sum X_{1}^{2}-\frac{\left(\sum X_{1}\right)^{2}}{n} \\
& B=\sum x_{2}^{2}=\sum X_{2}^{2}-\frac{\left(\sum X_{2}\right)^{2}}{n} \\
& C=\sum y^{2}=\sum Y^{2}-\frac{\left(\sum Y\right)^{2}}{n}
\end{aligned}
$$

$$
\begin{aligned}
& D=\sum x_{1} y=\sum X_{1} Y-\frac{\left(\sum X_{1} \sum Y\right)}{n} \\
& E=\sum x_{2} y=\sum X_{2} Y-\frac{\left(\sum X_{2} \sum Y\right)}{n} \\
& F=\sum x_{1} x_{2}=\sum X_{1} X_{2}-\frac{\left(\sum X_{1} \sum X_{2}\right)}{n}
\end{aligned}
$$

Sehingga persamaan 8.8 dan 8.9 dapat dituliskan kembali sebagaimana persamaan 8.10 dan 8.11 sebagai berikut :

$$
b_{1}=\frac{(B . D)-(E . F)}{(A . B)-(F)^{2}}
$$




$$
b_{2}=\frac{(A . E)-(D . F)}{(A . B)-(F)^{2}}
$$

Menurut Walpole dan Myers (1986), persamaan untuk menghitung nilai intercept (a) pada analisis regresi linier berganda yang melibatkan dua variabel prediktor dinyatakan sebagaimana persamaan 8.12 sebagai berikut :

$$
a=\frac{\left(\sum Y\right)-\left(b_{1} \sum X_{1}\right)-\left(b_{2} \sum X_{2}\right)}{n}
$$

\subsection{Analisis Korelasi}

Seperti yang sudah dijelaskan pada bagian pendahuluan, analisis korelasi hanya digunakan untuk mengetahui keeratan hubungan antara dua variabel, tanpa perlu memperhatikan variabel yang dipengaruhi atau variabel yang mempengaruhi. Menurut Supranto (2008), persamaan untuk menghitung koefisien korelasi dinyatakan sebagaimana persamaan 8.13 sebagai berikut: 


$$
r=\frac{n \sum_{i=1}^{n} x_{i} y_{i}-\left(\sum_{i=1}^{n} x_{i}\right)\left(\sum_{i=1}^{n} y_{i}\right)}{\sqrt{\left(n \sum_{i=1}^{n} x_{i}^{2}-\left(\sum_{i=1}^{n} x_{i}\right)^{2}\right)\left(n \sum_{i=1}^{n} y_{i}^{2}-\left(\sum_{i=1}^{n} y_{i}\right)^{2}\right)}}
$$

di mana :

$X=$ variabel prediktor

$\mathrm{Y}=$ variabel respon

$i=1,2,3, \ldots, n$

$n=$ jumlah data

Koefsien korelasi bisa bernilai positif atau negatif dan nilai koefisien korelasi berkisar antara -1 sampai dengan 1 . Korelasi negatif ditunjukkan dengan koefisien korelasi yang bernilai negatif begitu juga sebaliknya korelasi positif ditunjukkan dengan koefisien korelasi yang bernilai positif.

\subsection{Contoh Kasus}

Untuk lebih memahami tentang uraian materi analisis regresi linier dan analisis korelasi yang telah dijelaskan berikut ini diberikan contoh kasus analisis regresi linier dan analisis korelasi. 
Suatu penelitian dilakukan untuk mengetahui pengaruh uang saku harian terhadap nilai rata-rata rapot siswa. Diambil sampel acak berukuran 9 dan diperoleh data yang disajikan sebagaimana Tabel 8.1 sebagai berikut :

Tabel 8.1 Data uang saku siswa dan nilai rata-rata rapot

\begin{tabular}{|c|c|c|}
\hline Mahasiswa & Uang saku & Nilai rata-rata rapot \\
\hline 1 & 30000 & 80,17 \\
\hline 2 & 25000 & 83,57 \\
\hline 3 & 15000 & 85,99 \\
\hline 4 & 20000 & 87,33 \\
\hline 5 & 25000 & 85,25 \\
\hline 6 & 35000 & 80,56 \\
\hline 7 & 15000 & 84,77 \\
\hline 8 & 20000 & 90,56 \\
\hline 9 & 20000 & 87,66 \\
\hline
\end{tabular}

Lakukan analisis regresi linier sederhana dan analisis korelasi pada data tersebut, selanjutnya interpretasikan hasil analisis yang telah dibuat!

$\underline{\text { Jawaban: }}$

a. Analisis regresi linier sederhana 
Langkah awal pada analisis regresi linier sederhana adalah menghitung slope (a) dan intercept (b), kemudian dilanjutkan dengan membentuk persamaan regresi dan menginterpretasikan persamaan regresi. Persamaan untuk menghitung slope (b) dinyatakan sebagaimana persamaan 8.6 sebagai berikut :

$$
b=\frac{n \sum_{i=1}^{n} x_{i} y_{i}-\left(\sum_{i=1}^{n} x_{i}\right)\left(\sum_{i=1}^{n} y_{i}\right)}{n \sum_{i=1}^{n} x_{i}^{2}-\left(\sum_{i=1}^{n} x_{i}\right)^{2}}
$$

Berdasarkan Tabel 8.1 diketahui bahwa :

\begin{tabular}{|c|c|c|c|c|c|}
\hline Mahasiswa & $\begin{array}{c}\text { Uang } \\
\text { saku (X) }\end{array}$ & $\begin{array}{c}\text { Nilai } \\
\text { rata-rata } \\
\text { rapot (Y) }\end{array}$ & $\mathrm{XY}$ & $\mathrm{X}^{2}$ & $\mathrm{Y}^{2}$ \\
\hline 1 & 30000 & 80,17 & 2405100 & 900000000 & 6427,23 \\
\hline 2 & 25000 & 83,57 & 2089250 & 625000000 & 6983,94 \\
\hline 3 & 15000 & 85,99 & 1289850 & 225000000 & 7394,28 \\
\hline 4 & 20000 & 87,33 & 1746600 & 400000000 & 7626,53 \\
\hline 5 & 25000 & 85,25 & 2131250 & 625000000 & 7267,56 \\
\hline 6 & 35000 & 80,56 & 2819600 & 1225000000 & 6489,91 \\
\hline 7 & 15000 & 84,77 & 1271550 & 225000000 & 7185,95 \\
\hline 8 & 20000 & 90,56 & 1811200 & 400000000 & 8201,11 \\
\hline 9 & 20000 & 87,66 & 1753200 & 400000000 & 7684,28 \\
\hline Jumlah & 205000 & 765,86 & 17317600 & 5025000000 & 65260,80 \\
\hline
\end{tabular}




$$
\begin{aligned}
& \sum_{i=1}^{n} x_{i} y_{i}=17317600 \\
& \sum_{i=1}^{n} x_{i}=205000 \\
& \sum_{i=1}^{n} y_{i}=765,86 \\
& \sum_{i=1}^{n} x_{i}^{2}=5025000000 \\
& n=9
\end{aligned}
$$

Sehingga diperoleh nilai slope (b) adalah sebagai berikut:

$$
b=\frac{(9)(17317600)-(205000)(765,86)}{(9)(5025000000)-(205000)^{2}}=\frac{-1142900}{3200000000}=-0,00036
$$

Persamaan untuk menghitung nilai intercept (a) dinyatakan sebagaimana persamaan 8.7 sebagai berikut :

$$
a=\bar{y}-b \bar{x}
$$

Berdasarkan Tabel 8.1 diketahui bahwa :

$$
\begin{aligned}
& \bar{y}=85,1 \\
& \bar{x}=22.777,78
\end{aligned}
$$

Sehingga diperoleh nilai intercept (a) adalah sebagai berikut:

$$
\begin{aligned}
a & =(85,1)-(-0,00036)(22.777,78) \\
& =93,3
\end{aligned}
$$


Persamaan regresi yang terbentuk adalah sebagai berikut :

$$
\hat{y}=a+b x \quad \longrightarrow \quad \hat{y}=93,3-0,00036 x
$$

Interpretasui model regresi :

1. Setiap penambahan 1000 rupiah uang saku maka akan menurunkan nilai rata-rata rapot sebesar 0,36.

2. Rata-rata nilai rapot adalah 93,3 saat uang saku bernilai 0

b. Analisis Korelasi

Persamaan untuk menghitung koefisien korelasi dinyatakan sebagaimana persamaan 8.13 sebagai berikut:

$$
r=\frac{n \sum_{i=1}^{n} x_{i} y_{i}-\left(\sum_{i=1}^{n} x_{i}\right)\left(\sum_{i=1}^{n} y_{i}\right)}{\sqrt{\left(n \sum_{i=1}^{n} x_{i}^{2}-\left(\sum_{i=1}^{n} x_{i}\right)^{2}\right)\left(n \sum_{i=1}^{n} y_{i}^{2}-\left(\sum_{i=1}^{n} y_{i}\right)^{2}\right)}}
$$

Berdasarkan Tabel 8.1 diketahui bahwa :

$$
\begin{array}{ll}
\sum_{i=1}^{n} x_{i} y_{i}=17317600 & \sum_{i=1}^{n} x_{i}^{2}=5025000000 \\
\sum_{i=1}^{n} x_{i}=205000 & \sum_{i=1}^{n} y_{i}^{2}=65260,80 \\
\sum_{i=1}^{n} y_{i}=765,86 & n=9
\end{array}
$$


Sehingga diperoleh nilai kofisien korelasi adalah sebagai berikut:

$$
r=\frac{9(17317600)-(205000)(765,86)}{\sqrt{\left[9(5025000000)-(205000)^{2}\right]\left[9(65621)-(765,86)^{2}\right]}}=-0,71
$$

Intrepretasi koefisien regresi :

Terjadi korelasi negatif antara uang saku dan nilai rata-rata rapot dan besar korelasi antara antara uang saku dan nilai rata-rata rapot adalah $-0,71$.

\subsection{Rangkuman}

- Analisis regresi didefinisikan sebagai metode statistika yang digunakan untuk mengetahui hubungan fungsional linear antara satu variabel respon dengan satu variabel prediktor

- Terdapat dua jenis variabel dalam analisis regresi yaitu variabel respon atau disebut dengan variabel dependen (Y) dan variabel prediktor atau disebut variabel independen $(\mathrm{X})$.

- Persamaan umum analisis regresi linier adalah sebagai berikut : 


$$
\hat{y}=a+b x
$$

dimana :

$\mathrm{a}=$ intercept

$\mathrm{b}=$ slope

- Intercept didefinisikan sebagai adalah rata-rata variabel respon (Y) saat variabel prediktor $(\mathrm{X})$ bernilai 0 . Sedangkan slope didefinisikan sebagai nilai yang menunjukkan seberapa besar kontribusi atau pengaruh yang diberikan oleh suatu variabel predikor $(\mathrm{X})$ terhadap variabel respon $(\mathrm{Y})$ atau dapat diartikan sebagai rata-rata pertambahan atau pengurangan pada variabel $\mathrm{Y}$ untuk setiap peningkatan satu satuan variabel $\mathrm{X}$

- Terdapat dua jenis analisis regresi linier yaitu analisis regresi linier sederhana dan analisis regresi linier berganda. Analisis regresi linier sederhana hanya melibatkan satu variabel prediktor sedangkan analisis regresi linier berganda melibatkan dua atau lebih variabel prediktor.

- Analisis korelasi adalah metode statistika yang digunakan untuk mengetahui keeratan hubungan antara dua variabel, tanpa memperhatikan variabel yang dipengaruhi dan variabel yang mempengaruhi 
- Koefsien korelasi bisa bernilai positif atau negatif dan nilai koefisien korelasi berkisar antara -1 sampai dengan 1.

\subsection{Latihan}

1. Hitunglah koefisien korelasi dan koefisien regresi untuk data pada tabel berikut ini :

\begin{tabular}{|c|c|c|}
\hline No & Y & $X$ \\
\hline 1 & 10 & 35 \\
\hline 2 & 25 & 55 \\
\hline 3 & 16 & 44 \\
\hline 4 & 18 & 47 \\
\hline 5 & 21 & 49 \\
\hline 6 & 13 & 36 \\
\hline 7 & 18 & 48 \\
\hline 8 & 19 & 49 \\
\hline 9 & 16 & 45 \\
\hline 10 & 23 & 50 \\
\hline
\end{tabular}

2. Sebuah penelitian dilakukan untuk mengetahui pengaruh nilai tryout matematika terhadap nilai UNAS matematiaka siswa. Diambil sampel acak berukuran 12 siswa dan diperoleh data yang disajikan pada tabel berikut ini: 


\begin{tabular}{|c|c|c|}
\hline Siswa & $\begin{array}{c}\text { Nilai } \\
\text { Tryout }\end{array}$ & Nilai UNAS \\
\hline 1 & 75 & 80 \\
\hline 2 & 80 & 86 \\
\hline 3 & 85 & 90 \\
\hline 4 & 83 & 88 \\
\hline 5 & 69 & 80 \\
\hline 6 & 87 & 91 \\
\hline 7 & 90 & 92 \\
\hline 8 & 75 & 84 \\
\hline 9 & 85 & 88 \\
\hline 10 & 84 & 87 \\
\hline 11 & 76 & 82 \\
\hline 12 & 79 & 85 \\
\hline
\end{tabular}

Lakukan analisis regresi dan analisis korelasi pada data tersebut, kemudian interpretasikan hasil analisis yang didapatkan

3. Lakukan pengumpulan data dikelas, catat uang saku perhari dan nilai UTS setiap mahaiswa. Selanjutnya lakukan analisis regresi linier sederhana untuk mengetahui pengaruh uang saku terhadap nilai UTS mahasiswa! 


\section{Daftar Pustaka}

Supranto, J. (2008). Statistik Teori dan Aplikasi. Jakarta :

Erlangga.

Walpole, R. E., \& Myers, R. H. (1986). Ilmu peluang dan

Statistika untuk Insinyur dan Ilmuwan (R. K.

Sembiring, Trans.). Bandung: Penerbit ITB.

Walpole, Ronald E. (1995). Pengantar Statistika. Jakarta :

PT. Gramedia Pustaka Utama. 
Halaman Ini Sengaja Dikosongkan 


\section{BAB 9}

\section{PENGUJIAN ASUMSI DAN ANALISA REGRESI}

\subsection{Pendahuluan}

Analisis regresi dapat didefinisikan sebagai metode statistika yang digunakan untuk mengetahui hubungan fungsional linear antara satu variabel respon dengan satu variabel prediktor. Analisis regresi tidak berakhir begitu model regresi sesuai. Harus dilakukan pemeriksaan plot residual dan statistik diagnostik lainnya untuk menentukan apakah model memadai dan asumsi regresi telah terpenuhi. Terdapat empat asumsi dasar dalam analisis regresi yaitu normalitas, non-heteroskedastisitas, non-autokorelasi dan non-multikolinieritas. Jika model tidak memadai, tidak akan mewakili data anda dengan benar (Minitab Inc., 2014). Sebagai contoh:

- koefisien standar error mungkin bias, menyebabkan nilai t dan p yang salah.

· Koefisien mungkin memiliki tanda yang salah. 
- Modelnya mungkin terlalu dipengaruhi oleh satu atau dua titik.

Tabel di bawah ini dapat digunakan untuk mengetahui apakah model regresi yang terbentuk sudah memadai atau tidak

Tabel 1. Pengujian Asumsi Analisis Regresi

\begin{tabular}{|c|c|c|}
\hline Asumsi Regresi & Metode & Keputusan \\
\hline Kenormalan & $\begin{array}{l}\text { Anderson } \\
\text { Darling } \\
\text { Ryan Joiner } \\
\text { Kolmogorov } \\
\text { Smirnov }\end{array}$ & $\begin{array}{l}\text { Normal bila } p \text {-value } \\
>0.05\end{array}$ \\
\hline $\begin{array}{l}\text { Non- } \\
\text { Heterokedastisitas }\end{array}$ & Uji Gleytser & $\begin{array}{lr}\text { Homogen } & \text { jika } \\
\text { semua } & \text { pengaruh } \\
\text { variabel } & \text { bebas } \\
\text { terhadap } & \text { absolut } \\
\text { error } & \text { tidak } \\
\text { signifikan } & \text { (p-value } \\
>0.05) & \end{array}$ \\
\hline
\end{tabular}




\begin{tabular}{|c|c|c|}
\hline Non-Autokorelasi & Durbin Watson & 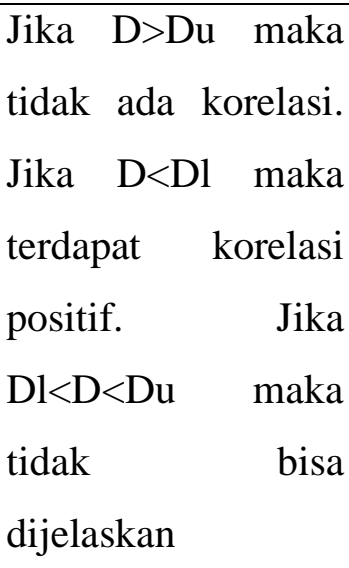 \\
\hline $\begin{array}{l}\text { Non- } \\
\text { Multikolinieritas }\end{array}$ & VIF & $\begin{array}{l}\text { Tidak ada } \\
\text { hubungan antara } \\
\text { variabel bebas } \\
\text { ketika VIF }<10\end{array}$ \\
\hline
\end{tabular}

\subsection{Pengujian Asumsi Analisis Regresi menggunakan Software Minitab}

Untuk lebih mudah memahami Pengujian Asumsi Analisis Regresi digunakan software Minitab. Berikut langkahlangkah analisis regresi berserta pengujian asumsi regresi dengan menggunakan software Minitab 17

\subsubsection{Analisis Regresi}

Pada contoh ini digunakan data exh_regression.mtw 


\section{Buka worksheet EXH_REGR.MTW.}

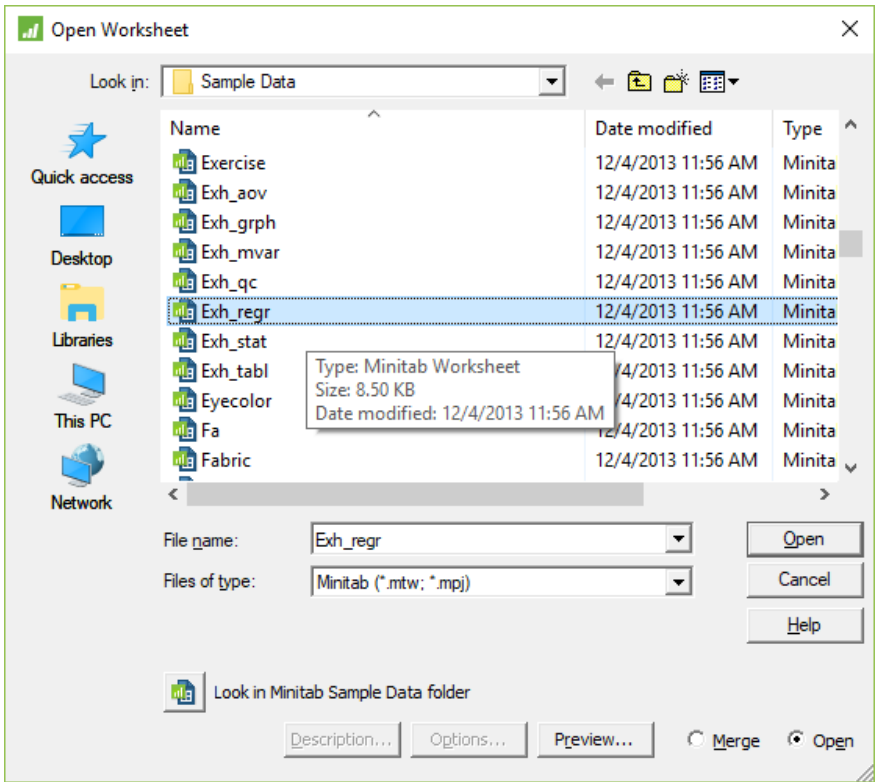

Pilih Stat $>$ Regression $>$ Regression $>$ Fit Regression Model. 
4 Minitab - Untitled

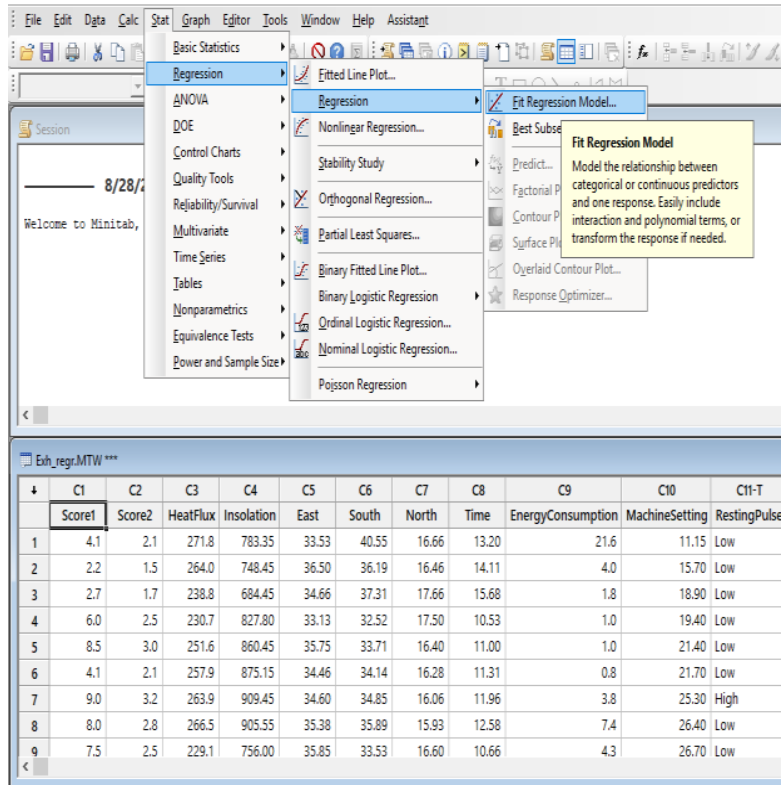

\section{Pada kotak Responses, masukkan HeatFlux.}

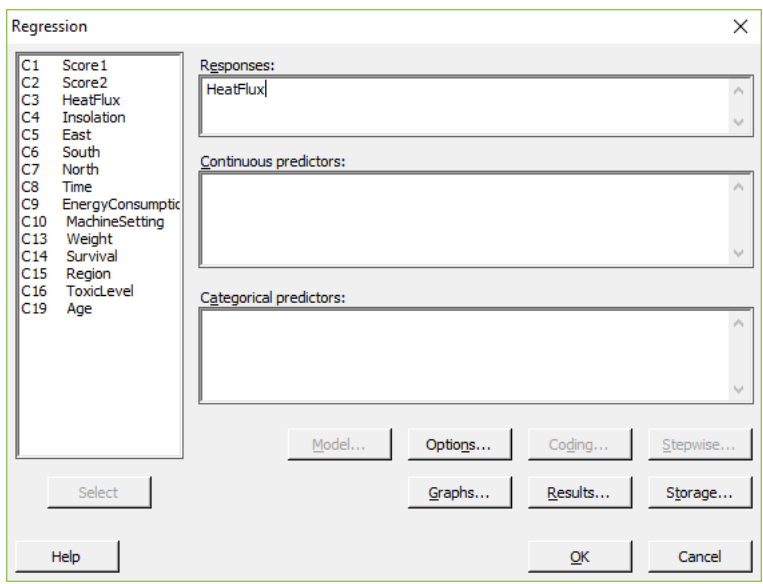


Pada kotak Continuous predictors, masukkan East South North.

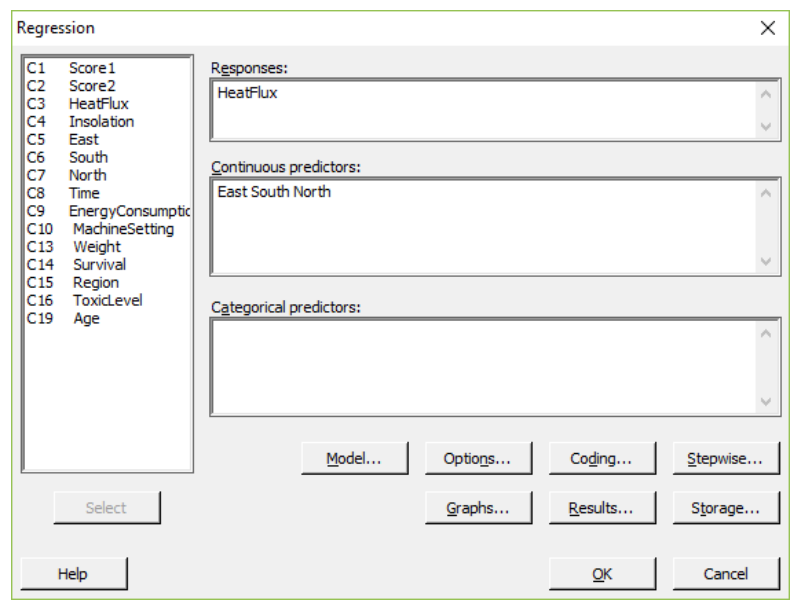

\section{Pada Results pilih Durbin Watson Statistics}

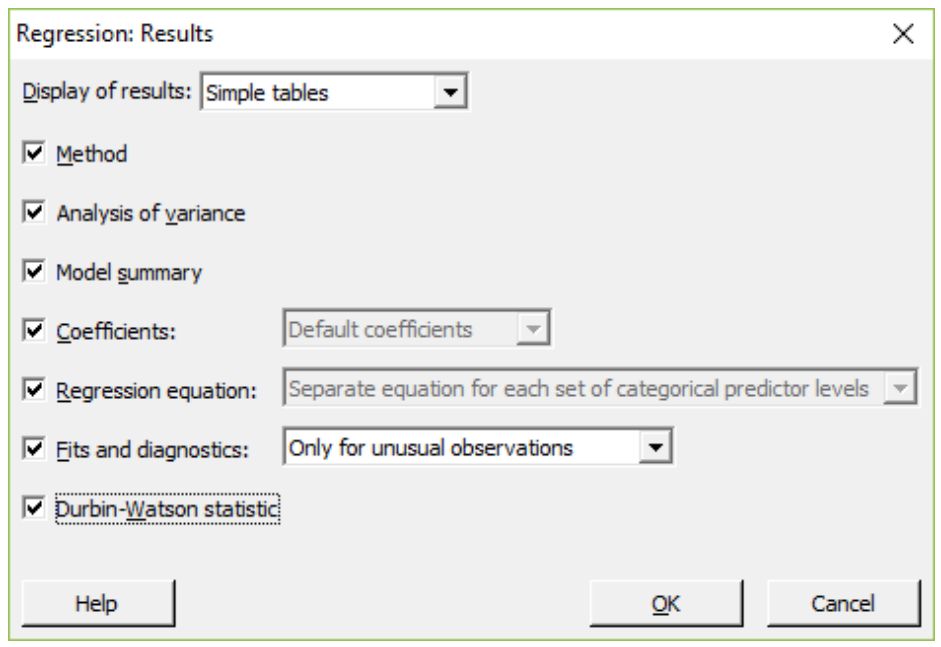

Pada Storage pilih Residuals 


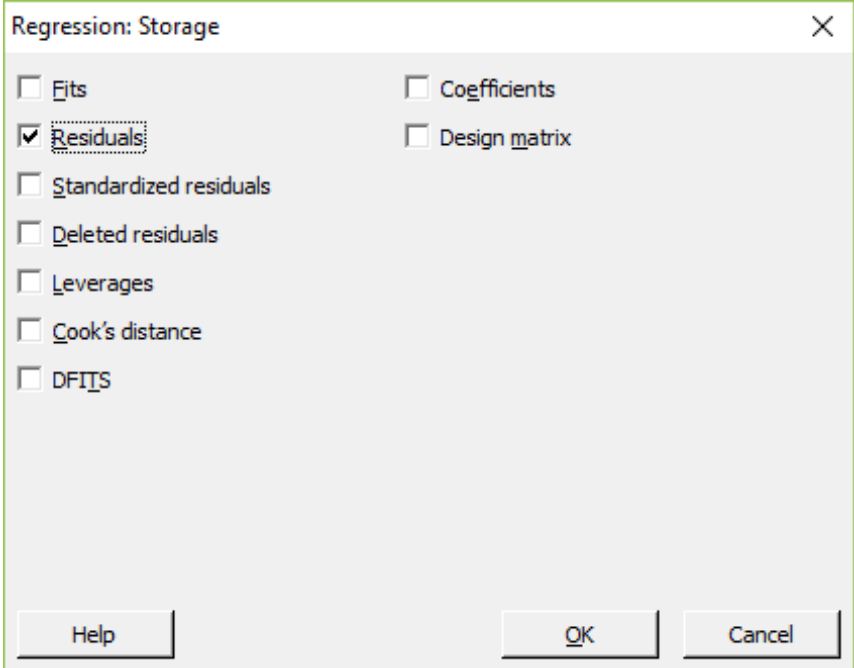

\section{Klik OK}

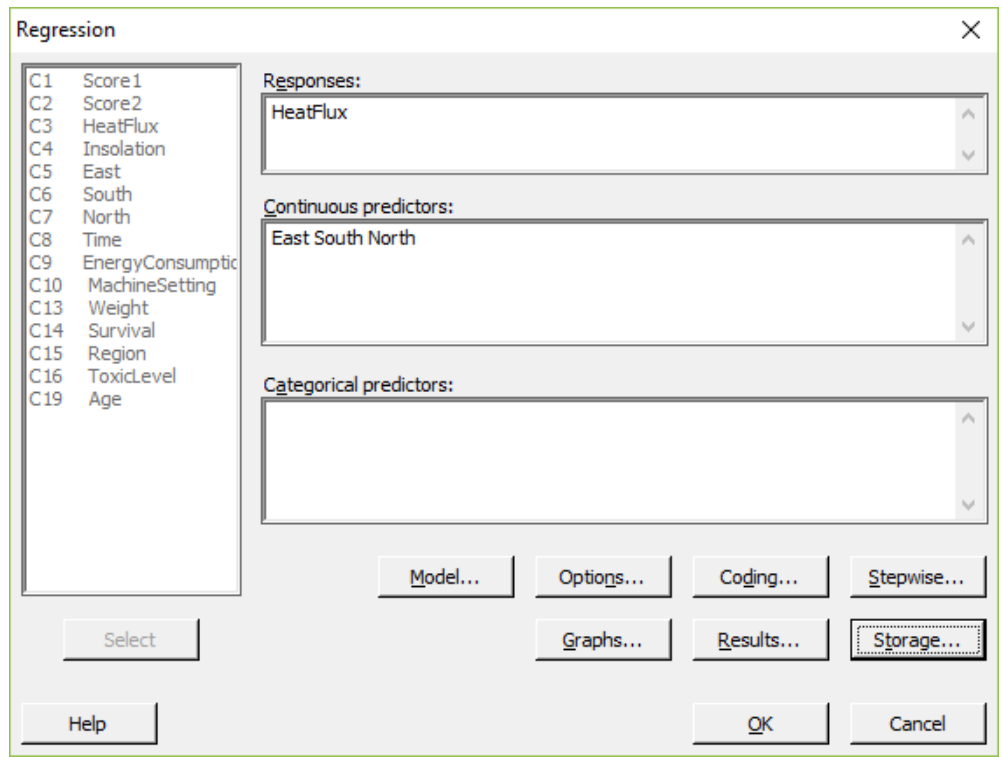


Hasil dari analisis regresi adalah sebagai berikut:

\author{
Results for: Exh_regr.MTW \\ Regression Analysis: HeatFlux versus East, South, North
}

Analysis of Variance

Source DF Adj SS Adj MS F-Value P-Value

$\begin{array}{llllll}\text { Regression } & 3 & 12833.9 & 4278.0 & 57.87 & 0.000\end{array}$

$\begin{array}{llllll}\text { East } & 1 & 226.3 & 226.3 & 3.06 & 0.092\end{array}$

$\begin{array}{llllll}\text { South } \quad & 1 & 2255.1 & 2255.1 & 30.51 & 0.000\end{array}$

North $\quad \begin{array}{lllll}1 & 12330.6 & 12330.6 & 166.80 & 0.000\end{array}$

Error $\quad 25 \quad 1848.1 \quad 73.9$

Total $28 \quad 14681.9$

Model Summary

S R-sq R-sq(adj) R-sq(pred)

$8.59782 \quad 87.41 \% \quad 85.90 \% \quad 78.96 \%$

Coefficients

Term Coef SE Coef T-Value P-Value VIF 


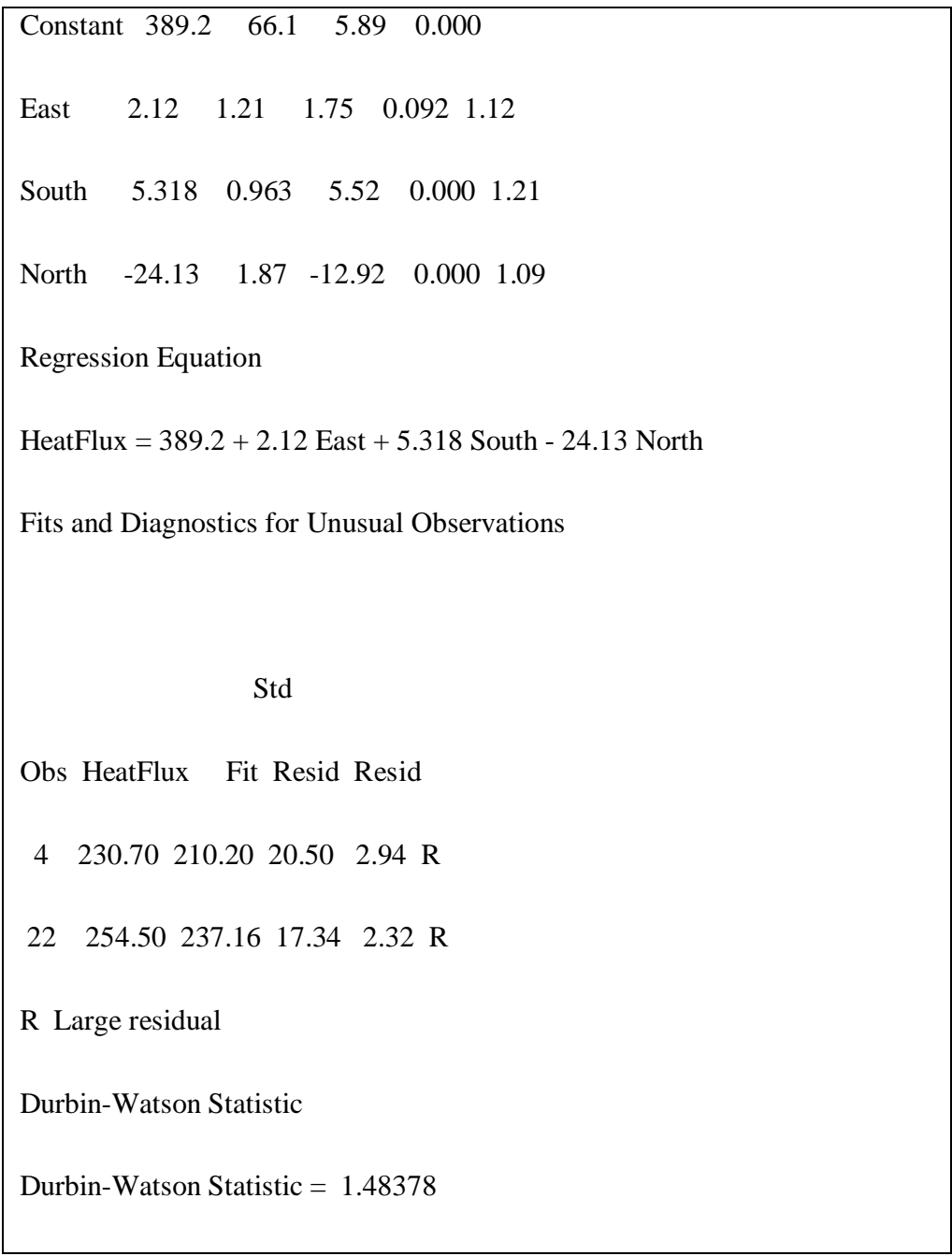

Selanjutnya berdasarkan hasil analisis regresi akan dilakukan empat asumsi dasar dalam analisis regresi yaitu normalitas, 
non-heteroskedastisitas, non-autokorelasi dan nonmultikolinieritas.

\subsubsection{Pengujian Normalitas}

Pada regresi, residual diharapkan menyebar normal. Terdapat 3 macam cara menguji kenormalan data pada minitab 17, yaitu Anderson Darling, Ryan Joiner dan Kolmogorov Smirnov (Colton, 2013). Berikut ini langkahlangkahnya pada minitab.

a. Anderson Darling (Alternatif 1)

Stat > Basic Statistics > Normality Test

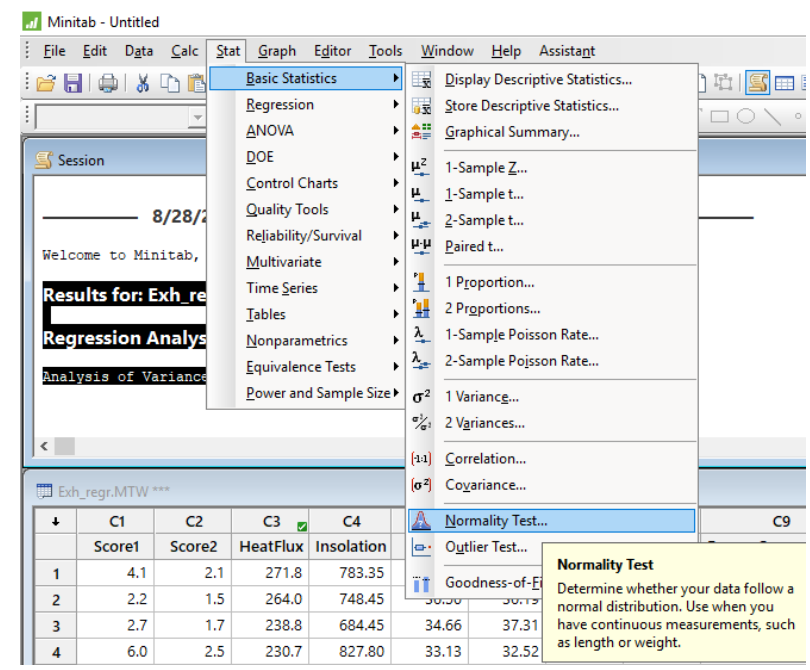

Isi Kotak Variable dengan RESI1 dan pilih Anderson Darling pada Test for Normality 


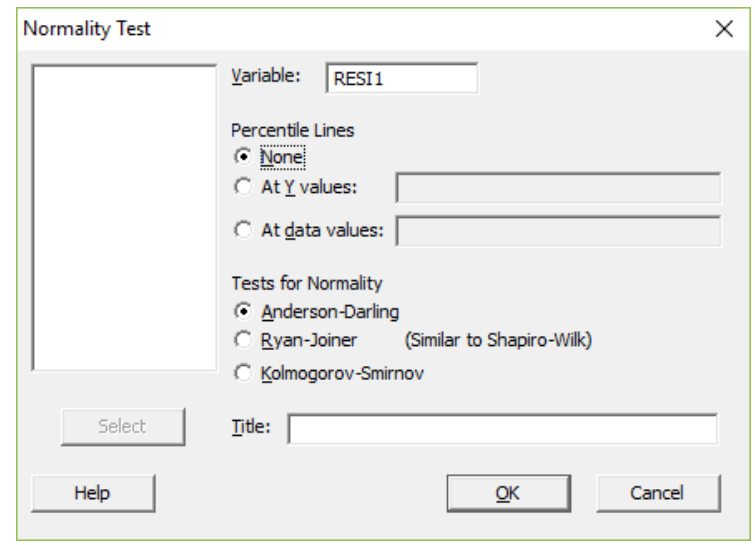

Hasil pengujian normalitas dengan andorson darling dapat dilihat seperti berikut:

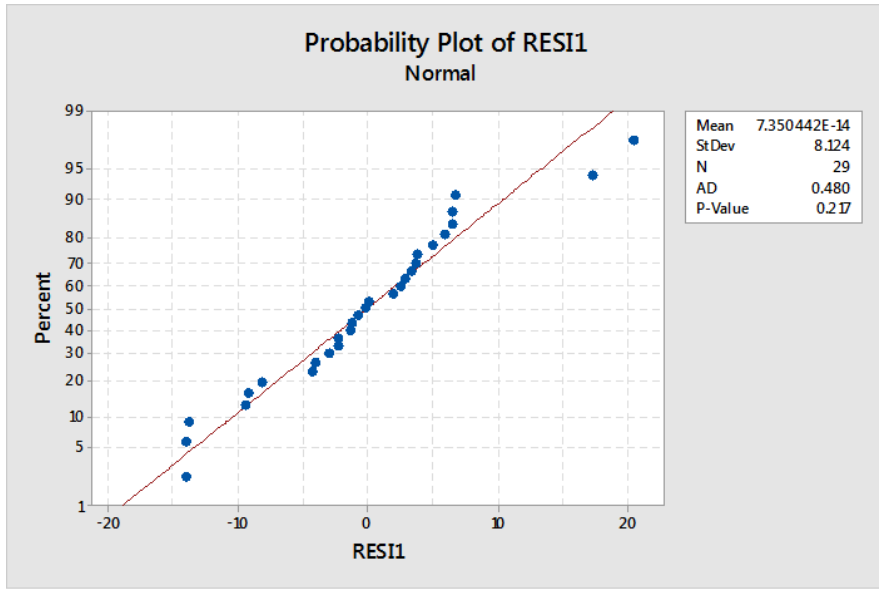

Pada contoh tersebut didapatkan nilai p-value (0.217) dimana nilai tersebut $>0.05$ sehingga dapat dikatakan bahwa asumsi normalitas pada regresi telah terpenuhi.

b. Ryan Joiner (Alternatif 2) 


\section{Stat $>$ Basic Statistics > Normality Test}

\begin{tabular}{|c|c|c|c|c|c|c|c|}
\hline Stat & Graph & Editor Iools & Window & Help A & ssistant & & \\
\hline & Basic Statis & stics & 国 Displ & y Descript & ve Statistics. & & 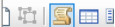 \\
\hline & Regression & - & $\overline{\mathrm{x}}$ Store & Descriptive & Statistics... & & \\
\hline & ANOVA & - & 壾 Grap & ical Summ & ary... & & -1 \\
\hline & $\underline{\mathrm{D} O E}$ & & $\boldsymbol{\mu}^{2} \quad 1-\mathrm{Sar}$ & ple Z.... & & & \\
\hline & Control Ch & harts & $\stackrel{1}{\mu}-\mathrm{Sar}$ & ple t... & & & \\
\hline & Quality To & ols & $\stackrel{2}{\rightleftarrows}-\mathrm{Sar}$ & ple t... & & & \\
\hline & Reliability/ & Survival & $\mu$ Paire & & & & \\
\hline & Time Serie & te & IH Pro & ortion... & & & \\
\hline & Tables & & "IH 2 Pro & ortions... & & & \\
\hline & Nonparam & hetrics & $\lambda$ 1-Sar & ple Poisso & n Rate... & & \\
\hline & Equivalenc & ce Tests & $\lambda=2-\operatorname{Sar}$ & iple Poisso & n Rate... & & \\
\hline & Power and & Sample Size & $\boldsymbol{\sigma}^{2} \quad 1 \operatorname{Var}$ & ince... & & & \\
\hline & & & $\sigma^{2} / 2=2$ Var & inces... & & & \\
\hline & & & {$[-1: 1]$ Corre } & ation... & & & \\
\hline & & & ( $\left.\boldsymbol{\sigma}^{2}\right]$ Cova & iance... & & & \\
\hline & C3 $\square$ & $\mathrm{C4}$ & A. Norn & ality Test... & & & C9 \\
\hline e2 & HeatFlux & Insolation & E. Outli & r Test... & & & \\
\hline 2.1 & 271.8 & 783.35 & $\because$ Good & ness-of- $\mathrm{Fi}$ & Normality & & \\
\hline 1.5 & 264.0 & 748.45 & Jo.so & 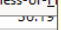 & $\begin{array}{l}\text { Determine } \\
\text { normal dis }\end{array}$ & $\begin{array}{l}\text { ether you } \\
\text { ution. Us }\end{array}$ & $\begin{array}{l}\text { ur data follov } \\
\text { se when you }\end{array}$ \\
\hline 1.7 & 238.8 & 684.45 & 34.66 & 37.31 & have conti & pus meas & surements, such \\
\hline 2.5 & 230.7 & 827.80 & 33.13 & 32.52 & as & & \\
\hline 3.0 & 251.6 & 860.45 & 35.75 & 33.71 & 16.40 & 11.00 & \\
\hline 2.1 & 257.9 & 875.15 & 34.46 & 34.14 & 16.28 & 11.31 & \\
\hline 3.2 & 263.9 & 909.45 & 34.60 & 34.85 & 16.06 & 11.96 & \\
\hline 2.8 & 266.5 & 905.55 & 35.38 & 35.89 & 15.93 & 12.58 & \\
\hline 2.5 & 229.1 & 756.00 & 35.85 & 33.53 & 16.60 & 10.66 & \\
\hline
\end{tabular}

Isi Kotak Variable dengan RESI1 dan pilih Ryan Joiner pada Test for Normality 


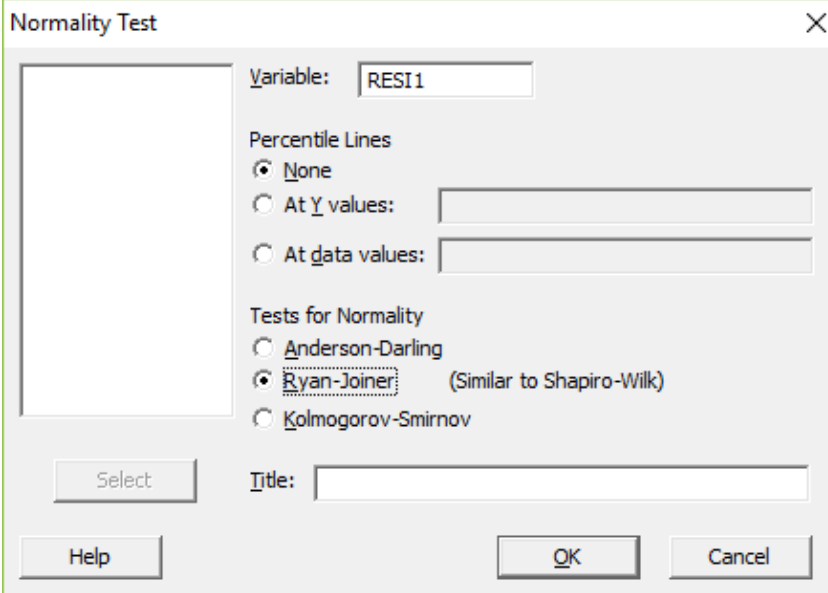

Hasil pengujian normalitas dengan ryan joiner dapat dilihat seperti berikut:

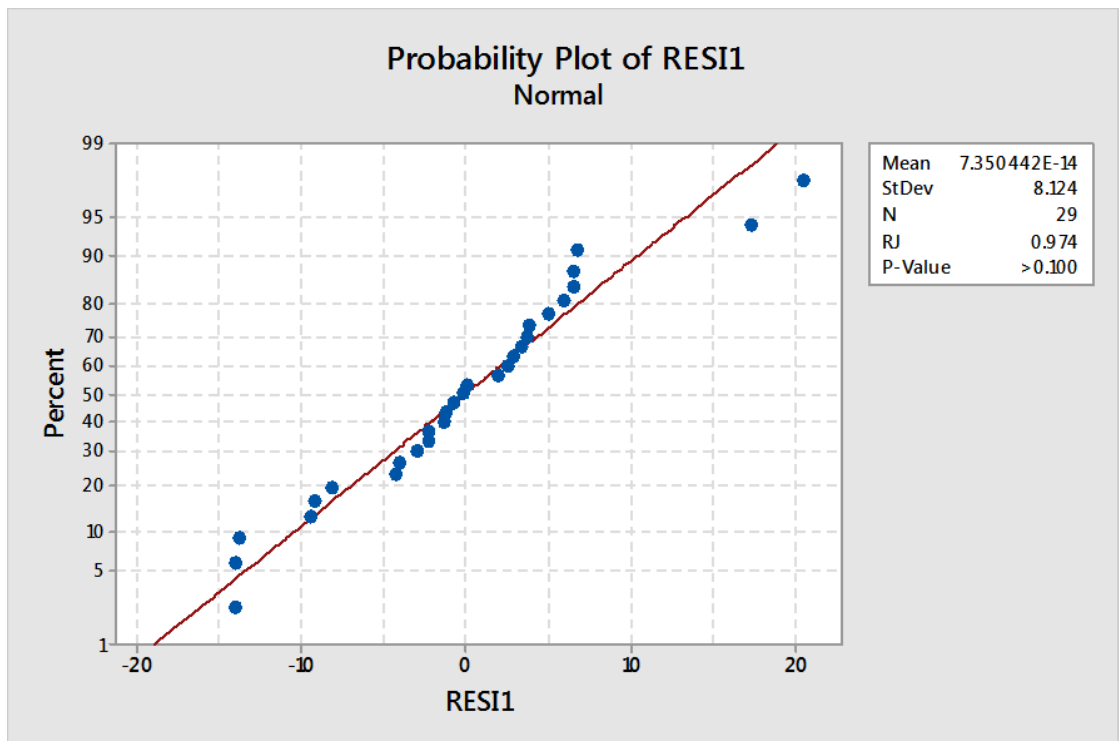


Pada contoh tersebut didapatkan nilai p-value $(>0.100)$ yang artinya nilai tersebut $>0.05$ sehingga dapat dikatakan bahwa asumsi normalitas pada regresi telah terpenuhi.

c. Kolmogorov Smirnov (Alternatif 3)

Stat $>$ Basic Statistics $>$ Normality Test

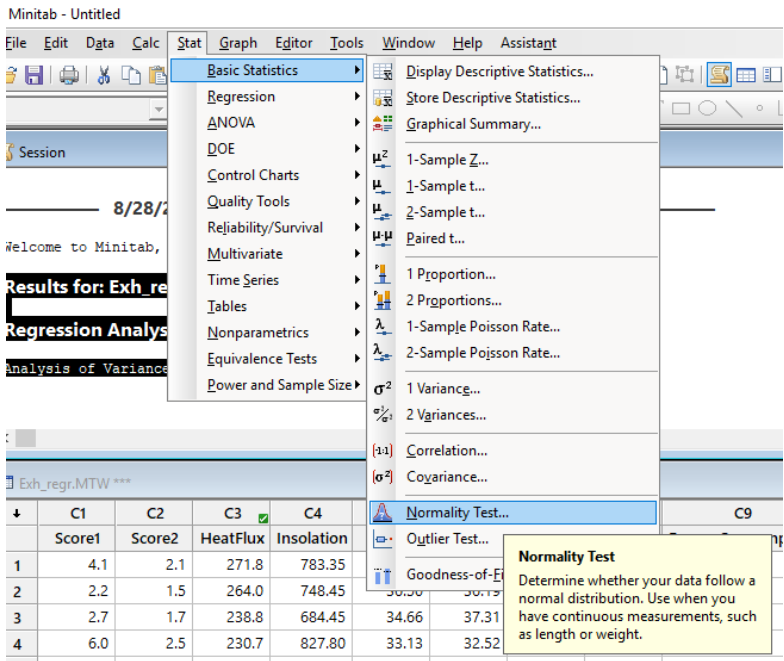

Isi Kotak Variable dengan RESI1 dan pilih Kolmogorov Smirnov pada Test for Normality 


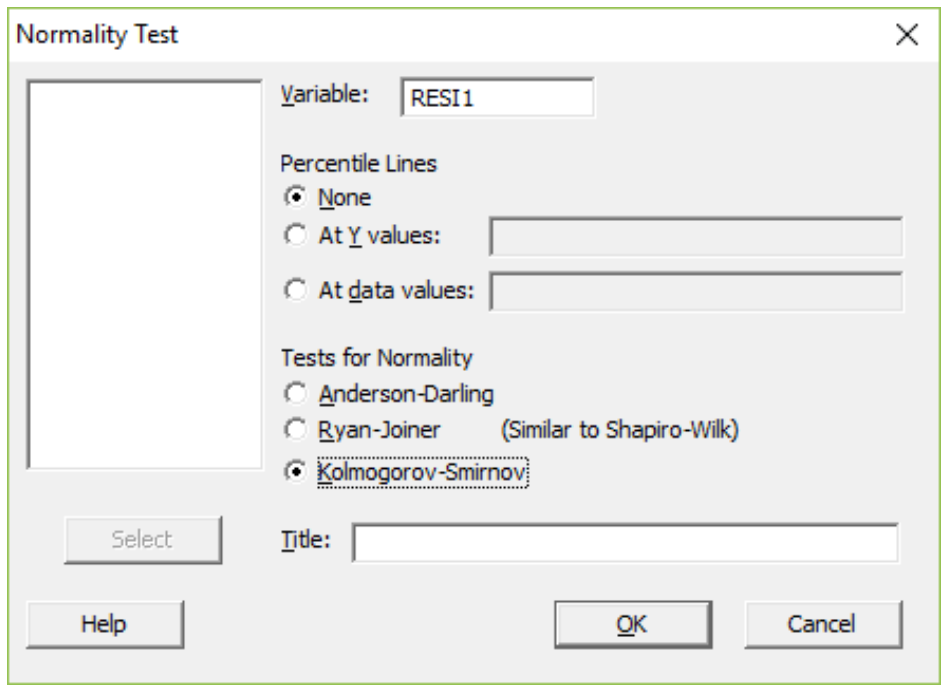


Hasil pengujian normalitas dengan Kolmogorov smirnov dapat dilihat seperti berikut:

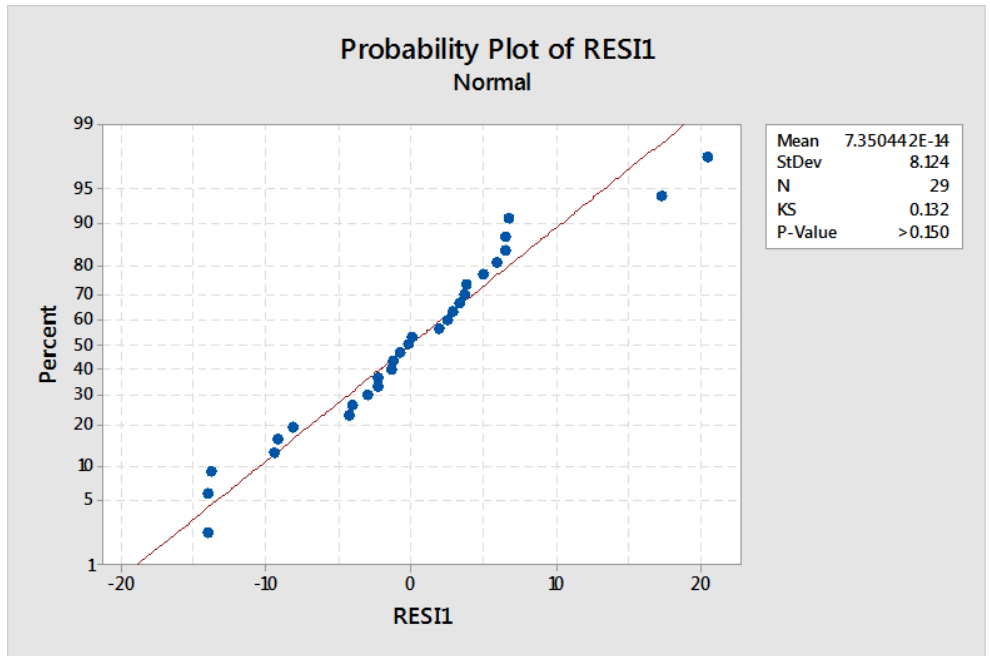

Pada contoh tersebut didapatkan nilai p-value (>0.150) yang berarti nilai tersebut $>0.05$ sehingga dapat dikatakan bahwa asumsi normalitas pada regresi telah terpenuhi.

\subsection{Pengujian Non-Heterokedastisitas}

Pada analisis regresi, uji ini digunakan untuk menguji apakah dalam model regresi terjadi ketidaksamaan varian dari residual satu pengamatan ke pengamatan lain. Jika ragam dari residual satu pengamatan ke pengamatan lain tetap maka disebut homokedastisitas, dan jika berbeda disebut heterokedastisitas. Model regresi yang baik adalah bila tidak 
terjadi heterokedastisitas. Salah satu cara pengujian nonheterokedastisitas adalah dengan metode glejser (Glejser, 1969) dengan langkah sebagai berikut:

a. Calc > Calculator

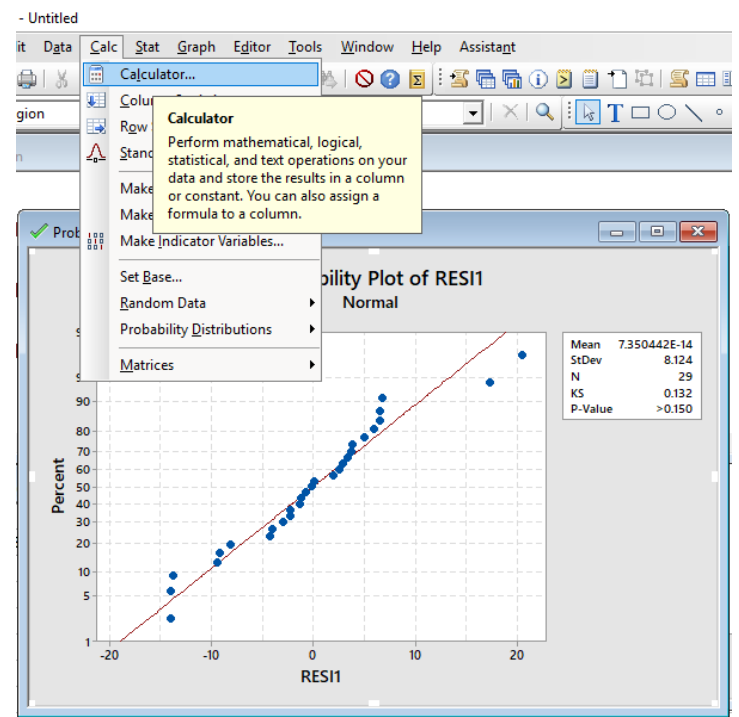

b. Pada kotak store result in variable isi dengan kolom yang masih kosong (misal C21) dan pada kotak Expression isi dengan ABS('RESI1') 


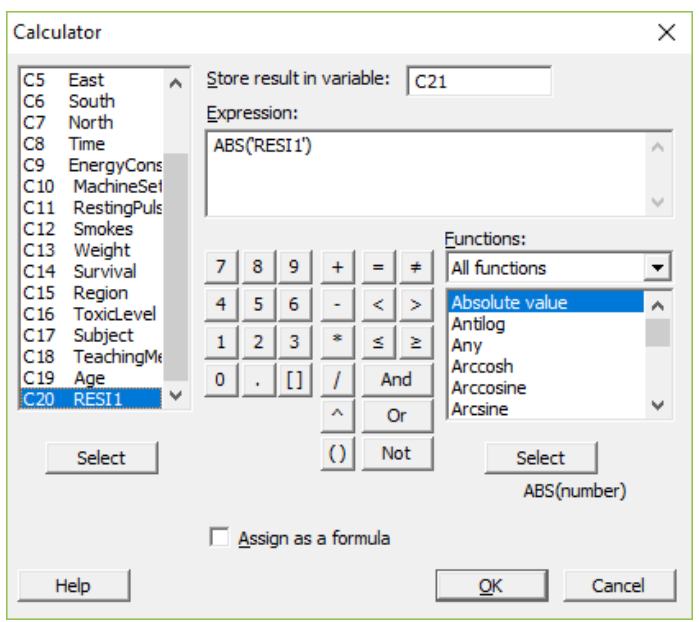

c. Pada kolom C21 akan muncul hasil sebagai berikut

\begin{tabular}{|c|c|c|c|c|}
\hline $18-\mathrm{T}$ & C19 & $\mathrm{C} 20$ & $\mathrm{C} 21$ & $\mathrm{C} 22$ \\
\hline \multirow[t]{10}{*}{ IgMethod } & Age & RESI1 & & \\
\hline & 10 & -2.2270 & 2.2270 & \\
\hline & 10 & 2.0245 & 2.0245 & \\
\hline & 10 & 3.7362 & 3.7362 & \\
\hline & 10 & 20.5014 & 20.5014 & \\
\hline & 10 & 2.9600 & 2.9600 & \\
\hline & 10 & 6.8181 & 6.8181 & \\
\hline & 10 & 3.4354 & 3.4354 & \\
\hline & 11 & -4.2904 & 4.2904 & \\
\hline & 11 & -13.9687 & 13.9687 & \\
\hline 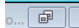 & 83 & & & \\
\hline
\end{tabular}

\section{d. Beri nama kolom C21 dengan ABSRES}

\begin{tabular}{|c|c|c|}
\hline $\mathrm{C} 20$ & $\mathrm{C} 21$ & $\mathrm{C} 22$ \\
\hline RESI1 & ABSRES & \\
\hline-2.2270 & 2.2270 & \\
\hline 2.0245 & 2.0245 & \\
\hline 3.7362 & 3.7362 & \\
\hline 20.5014 & 20.5014 & \\
\hline 2.9600 & 2.9600 & \\
\hline 6.8181 & 6.8181 & \\
\hline 3.4354 & 3.4354 & \\
\hline-4.2904 & 4.2904 & \\
\hline-13.9687 & 13.9687 & \\
\hline
\end{tabular}




\section{e. Klik Stat $>$ Regression $>$ Regression $>$ Fit Regression}

\section{Model}

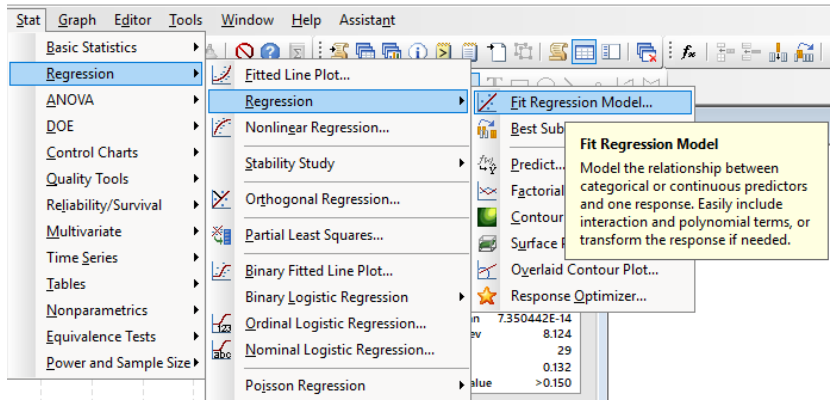

\section{f. Pada kotak responses ganti isinya menjadi ABSRES}

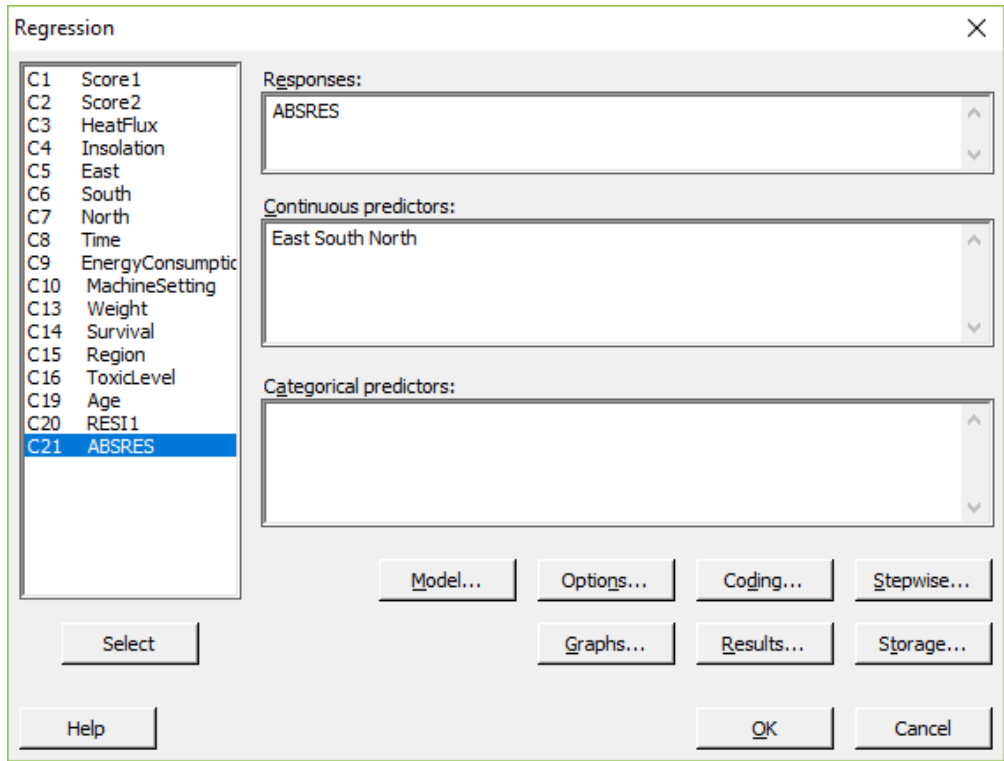

\section{g. Klik Result dan hilangkan centang Durbin-Watson}

Statistic 


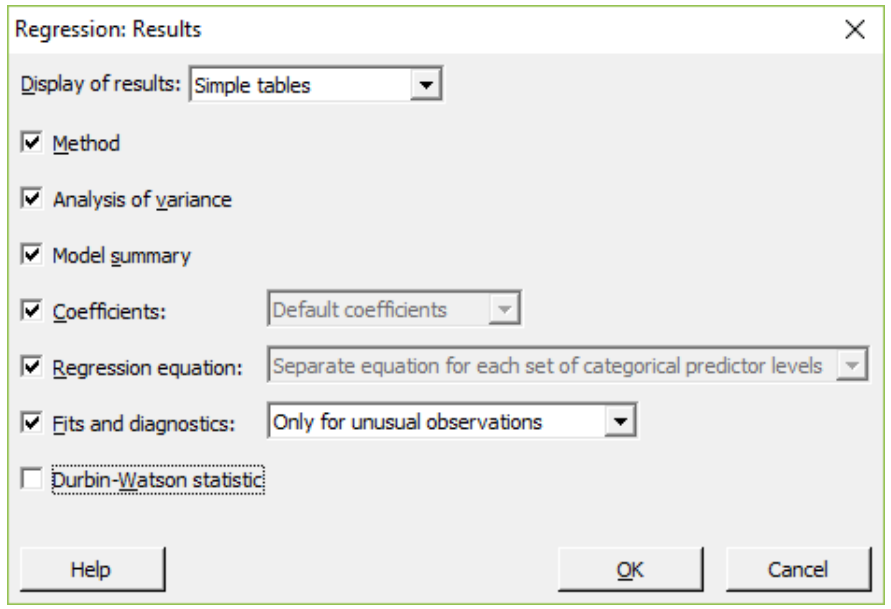

h. Pada Storage Hilangkan centang residuals

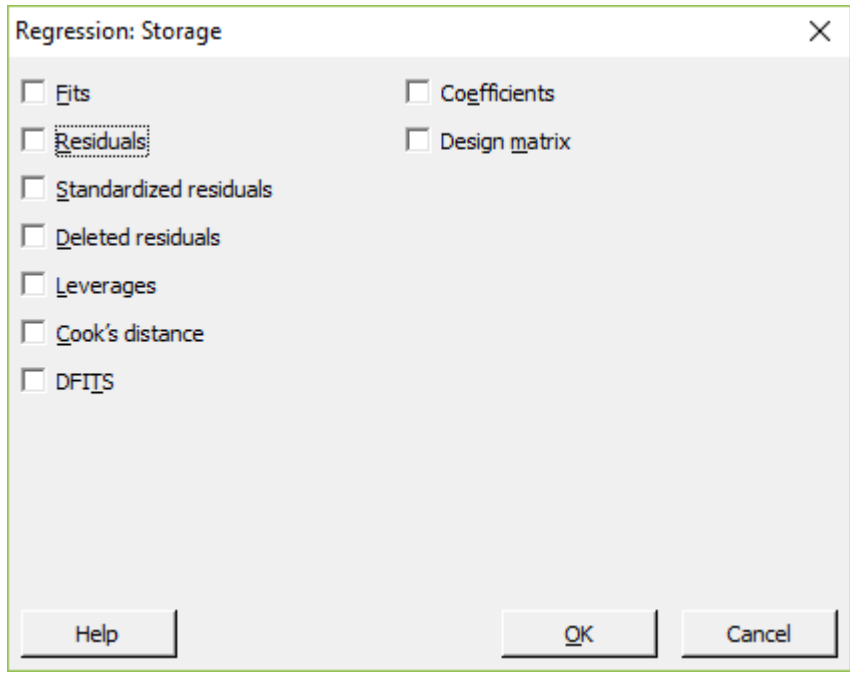

i. Klik OK dan hasilnya adalah sebagai berikut:

Regression Analysis: ABSRES versus East, South, North

Analysis of Variance 


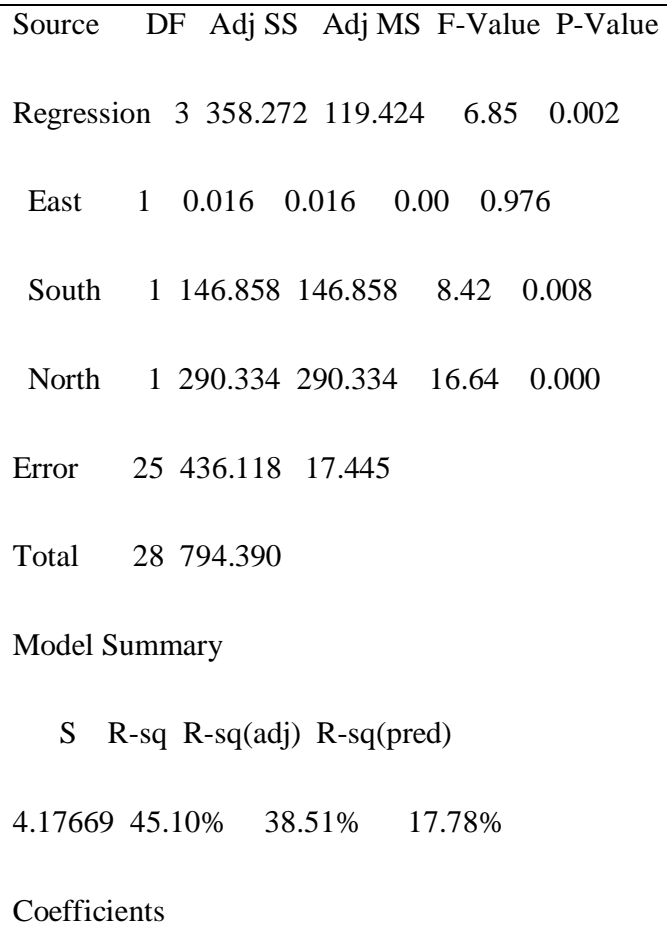


Fits and Diagnostics for Unusual Observations

Std

Obs ABSRES Fit Resid Resid

$\begin{array}{llllll}4 & 20.50 & 13.03 & 7.47 & 2.20 \mathrm{R}\end{array}$

$\begin{array}{llllll}22 & 17.34 & 8.48 & 8.86 & 2.44 & \mathrm{R}\end{array}$

$\mathrm{R}$ Large residual

Pada hasil minitab tersebut, kita fokus pada nilai pvalue pada uji t. Jika nilai p-value dari semua variabel prediktor terdapat minimal satu varibel yang memiliki p-value $<0.05$ maka terjadi heterokedastisitas sehingga model regresi yang dibentuk kurang baik untuk digunakan.

\subsection{Uji Non-Autokorelasi}

Pengujian autokorelasi dimaksudkan untuk mengetahui apakah residual bersifat bebas atau tidak terdapat korelasi antara satu dengan yang lain. Salah satu metode pengujian non-autokorelasi adalah dengan uji Durbin-Watson. Jika $\mathrm{D}>\mathrm{Du}$ maka tidak ada korelasi, jika $\mathrm{D}<\mathrm{Dl}$ maka terdapat korelasi positif, namun jika $\mathrm{Dl}<\mathrm{D}<\mathrm{Du}$ maka tidak bisa dijelaskan (Minitab Inc., 2014). Nilai D pada minitab 17 
sebenarnya sudah kita keluarkan pada saat analisis regresi (karena kita mencentang Durbin-Watson Statistic).

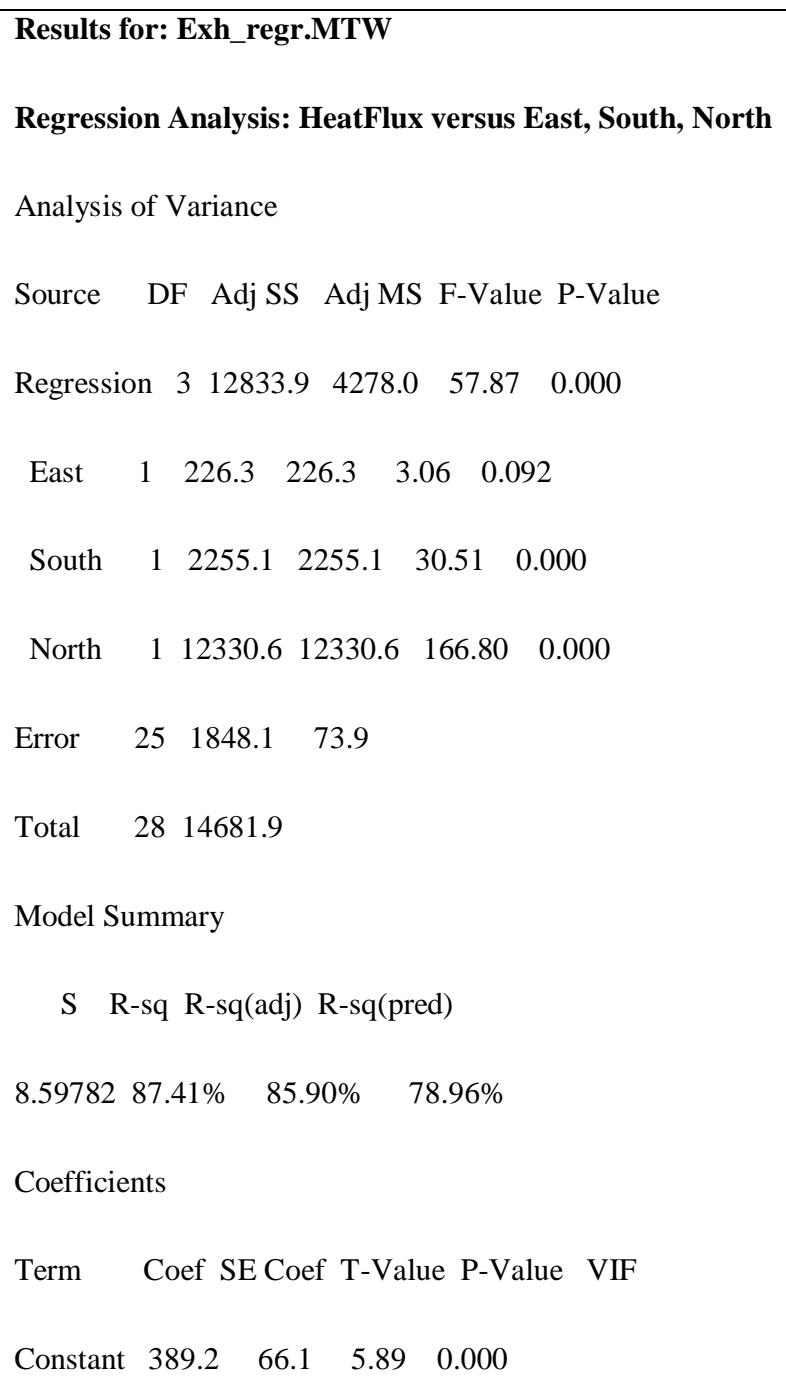




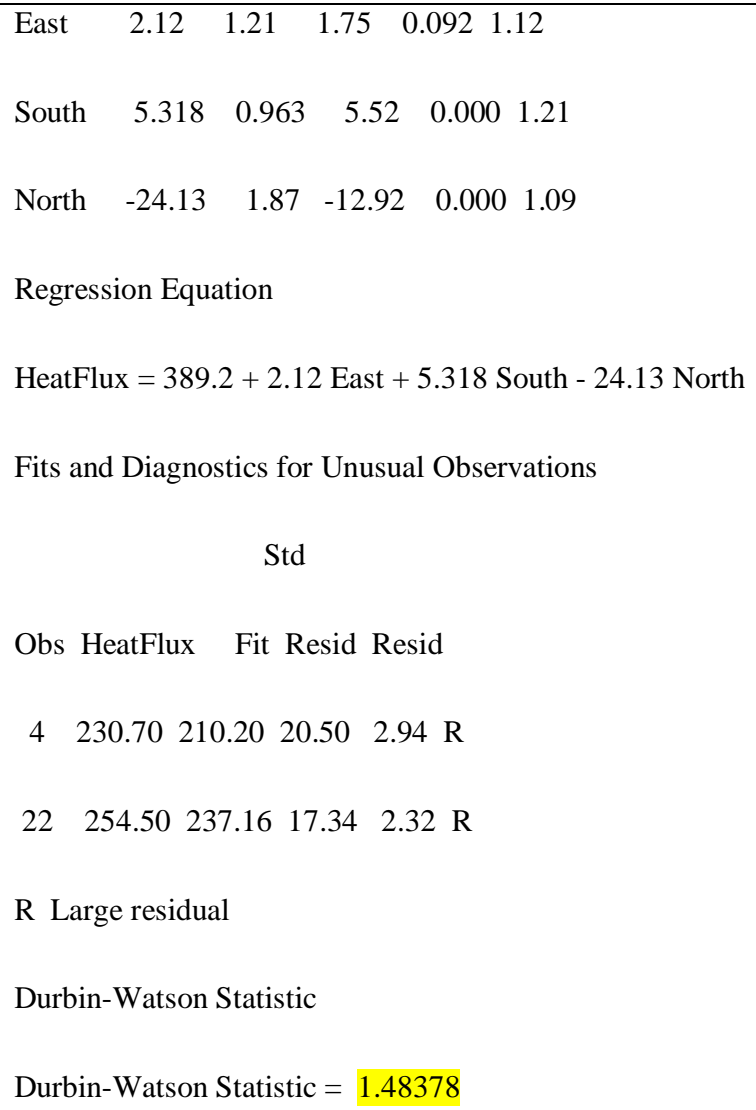

Nilai D pada hasil di atas adalah 1.48378 , dengan $n$ sebesar 29 dan $\mathrm{k}$ sebesar 2 maka didapatkan $\mathrm{Dl}=1.270$ dan $\mathrm{Du}=1.563$. Karena $\mathrm{Dl}<\mathrm{D}<\mathrm{Du}$ maka tidak dapat dijelaskan ada tidaknya autokorelasi. 


\subsection{Uji Non-Multikolinieritas}

Pada regresi, diharapkan antar variabel prediktor benarbenar saling bebas. Untuk itu perlu pengujian untuk mengetahui ada tidaknya multikolinieritas. Pada minitab 17, sebenarnya hasil multikolinieritas dapat dilihat langsung pada hasil regresi variabel prediktor terhadap variabel respon. Kita fokuskan perhatian pada nilai VIF, jika nilai VIF lebih dari 10 maka dapat dikatakan terdapat multikolinieritas (Martz, 2013).

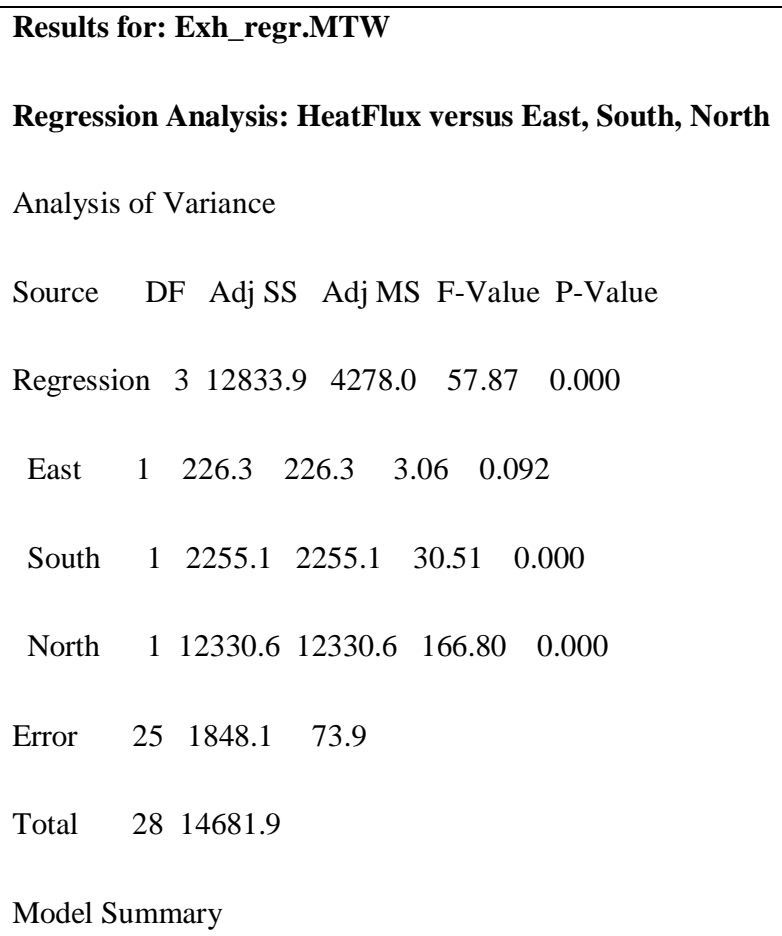




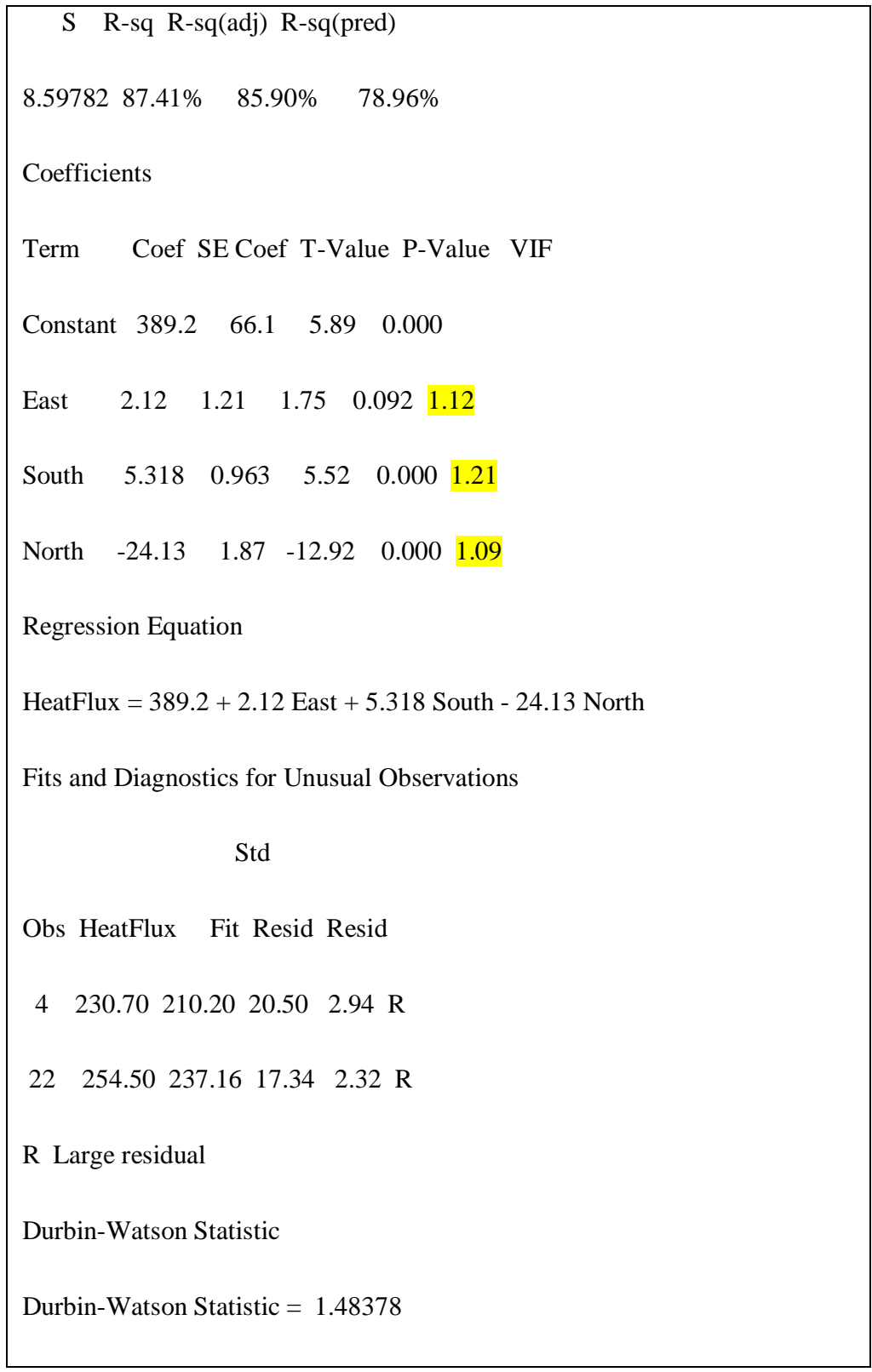


Berdasarkan hasil tersebut dapat kita lihat bahwa nilai VIF untuk semua variabel prediktor memiliki nilai VIF < 10 maka dapat disimpulkan bahwa tidak terjadi multikolinieritas antar variabel prediktor. 


\subsection{Rangkuman}

Analisis regresi dapat didefinisikan sebagai metode statistika yang digunakan untuk mengetahui hubungan fungsional linear antara satu variabel respon dengan satu variabel prediktor. Analisis regresi tidak berakhir begitu model regresi sesuai. Harus dilakukan pemeriksaan plot residual dan statistik diagnostik lainnya untuk menentukan apakah model memadai dan asumsi regresi telah terpenuhi. Berikut adalah empat jenis pengujian asumsi dilakukan pada analisis regresi:

\begin{tabular}{|l|l|l|}
\hline Asumsi Regresi & Metode & Keputusan \\
\hline Kenormalan & $\begin{array}{l}\text { Anderson } \\
\text { Darling } \\
\text { Ryan Joiner } \\
\text { Kolmogorov } \\
\text { Smirnov }\end{array}$ & $\begin{array}{l}\text { Normal bila p- } \\
\text { value }>0.05\end{array}$ \\
\hline Non-Heterokedastisitas & Uji Gleytser & $\begin{array}{l}\text { Homogen jika } \\
\text { semua pengaruh } \\
\text { variabel bebas } \\
\text { terhadap absolut }\end{array}$ \\
\hline
\end{tabular}




\begin{tabular}{|c|c|c|}
\hline & & $\begin{array}{l}\text { error tidak } \\
\text { signifikan }(p- \\
\text { value > 0.05) }\end{array}$ \\
\hline Non-Autokorelasi & Durbin Watson & 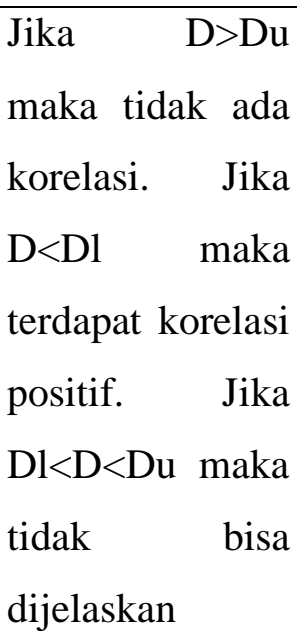 \\
\hline Non-Multikolinieritas & VIF & $\begin{array}{l}\text { Tidak ada } \\
\text { hubungan antara } \\
\text { variabel bebas } \\
\text { ketika VIF }<10\end{array}$ \\
\hline
\end{tabular}




\subsection{Latihan}

Berikut ini terdapat data dengan X1 dan X2 adalah varibel prediktor dan Y adalah variabel respon!

\begin{tabular}{|c|c|c|}
\hline $\mathrm{X} 1$ & $\mathrm{X} 2$ & $\mathrm{Y}$ \\
\hline 40 & 24 & 33 \\
\hline 62 & 75 & 66 \\
\hline 58 & 57 & 51 \\
\hline 48 & 38 & 35 \\
\hline 47 & 63 & 54 \\
\hline 66 & 9 & 33 \\
\hline 3 & 47 & 31 \\
\hline 19 & 74 & 50 \\
\hline 39 & 25 & 30 \\
\hline 57 & 70 & 66 \\
\hline 64 & 58 & 58 \\
\hline 30 & 20 & 21 \\
\hline 41 & 31 & 31 \\
\hline 68 & 46 & 46 \\
\hline 66 & 63 & 56 \\
\hline 57 & 17 & 33 \\
\hline 1 & 81 & 53 \\
\hline 45 & 45 & 43 \\
\hline 36 & 34 & 30 \\
\hline 28 & 92 & 66 \\
\hline
\end{tabular}

1. Lakukan analisis regresi pada data di atas

2. Lakukan empat pengujian asumsi regresi,setelah analisis regresi telah dilakukan 


\section{Daftar Pustaka}

Colton, J., 2013. Anderson-Darling, Ryan-Joiner, or Kolmogorov-Smirnov: Which Normality Test Is the Best?. [Online]

Available at: http://blog.minitab.com/blog/the-statisticalmentor/anderson-darling-ryan-joiner-or-kolmogorov$\underline{\text { smirnov-which-normality-test-is-the-best }}$ [Accessed 2017].

Evans, W. N., 2016. Durbin Watson Significance Tables. [Online]

Available at:

https://www3.nd.edu/ wevans1/econ30331/Durbin_Watson_t ables.pdf

[Accessed 2017].

Glejser, H., 1969. A New Test for Heteroskedasticity. Journal of the American Statistical Association, 64(235), pp. 315-323.

Martz, E., 2013. Enough Is Enough! Handling Multicollinearity in Regression Analysis. [Online] Available at: http://blog.minitab.com/blog/understanding$\underline{\text { statistics/handling-multicollinearity-in-regression-analysis }}$ [Accessed 2017]. 
Minitab Inc., 2014. Minitab Statistical Software, Release 17 for Windows. Pennsylvania: Minitab Inc.. 


\section{BAB 10}

\section{ANALISIS RAGAM}

\subsection{Pendahuluan}

Analisis Ragam atau Analisis Varian (Analysis of Varians/ANOVA) akan memperluas pengujian kesamaan dari dua nilai rata-rata menjadi kesamaan beberapa nilai rata-rata secara simultan. Analisis Varian adalah suatu metode untuk menguraikan keragaman total menjadi komponen-komponen yang mengukur berbagai sumber kergaman/variansi. Pada pengujian ANOVA, dengan mudah akan diketahui apakah terdapat perbedaan signifikan atau tidak dari beberapa nilai rata-rata contoh yang diselidiki, yang pada akhirnya diperoleh suatu keyakinan menerima hipotesis nol atau menerima hipotesis alternatifnya. Langkah selanjutnya adalah mengetahui besarnya ragam/variansi populasi $\sigma^{2}$. Untuk mengetahui variansi populasi, kita perlu melakukan pendugaan besarnya variansi antar kelompok dan variansi dalam sampel. Bila keduanya variansi sangat kecil atau mendekati 1, kemungkinan menerima Ho dapat diterima, begitu pula sebalikanya. 


\subsection{Analisis Ragam Satu Arah}

Konsep Analisis variansi (ANOVA) didasarkan pada distribusi $-\mathrm{F}$ dan dapat diaplikasikan untuk berbagai macam kasus dalam analisis hubungan antara berbagai variabel yang diamati. Dalam perhitungan statistik, analisis ragam sangat dipengaruhi oleh asumsi-asumsi yang digunakan seperti kenormalan dari distribusi, homogenitas dari ragam dan kebebasan dari kesalahan. Asumsi kenormalan distribusi memberikan penjelasan terhadap karakteristik tiap data setiap kelompok. Asumsi homogenitas ragam menjelaskan bahwa ragam dalam asing-masing kelompok dianggap sama, sedangkan asumsi bebas menjelaskan bahwa ragam masing-masing terhadap rataratanya pada setiap kelompok bersifat saling bebas.

\subsubsection{Teknik Analisis Ragam Satu Arah}

\subsubsection{Data Seragam}

Misalnya kita mempunyai $\mathrm{r}$ populasi yang bebas dan terdistribusi normal dengan rata-rata $\mu 1, \mu 2, \ldots \mu$ r dan ragam yang sama yaitu $\sigma^{2}$ dan dari masing-masing populasi diambil sampel acak berukuran n. Kita akan mencari pengujian hipotesis seperti dalam tabel dibawah ini : 
Tabel 9.1. Nilai pengamatan analisis ragam satu arah

\begin{tabular}{|c|c|c|}
\hline Populasi & Asumsi Distribusi & Nilai Pengamatan \\
\hline 1 & $\mathrm{~N}\left(\mu 1, \sigma^{2}\right)$ & $X 1 j(j=1,2, . ., n)$ \\
\hline 2 & $\mathrm{~N}\left(\mu 2, \sigma^{2}\right)$ & $X 2 j(j=1,2, . ., n)$ \\
\hline . & n.......... & $\cdots \cdots$ \\
\hline$\cdot$ & n........ & n........ \\
\hline $\mathrm{r}$ & $\mathrm{N}\left(\mu \mathrm{r} \sigma^{2}\right.$ & $\mathrm{Xij}(\mathrm{j}=1,2, . ., \mathrm{n})$ \\
\hline \multicolumn{3}{|c|}{ Hipotesis nol : Ho $=\mu 1, \mu 2, \ldots \mu \mathrm{r}$} \\
\hline \multicolumn{3}{|c|}{ Hipotesis alternatif : $\mathrm{H} 1: \mu 1 \neq \mu 1$, untuk beberapa $\mathrm{i} \neq 1$} \\
\hline
\end{tabular}

(Wibisono,2009)

Misalkan Xij merupakan pengamatan ke-j dari populasi ke-i. Setiap pengamatan Xij dari nilai rata-rata dapat dibedakan menjadi dua yaitu rata-rata populasi ke-i dan simpangan eij pengamatan ke-j dalam contoh ke-I dari rataratanya. Jumlah kuadrat total (JKT) sama dengan jumlah kuadrat rata-rata baris atau perlakuan (JKB) ditambah jumlah kuadrat galat (JKG). Jumlah kuadrat masing-masing suku menggambarkan keragaman masing-masing komponen. Dengan demikian pengujian hipotesis nol dapat dilakukan 
dengan membandingkan dengan dua nilai dugaan bebas bagi ragam populasinya. Untuk menghitung nilai JKT, JKB maupun JKG tidaklah mudah. Namun secara praktis nilainilai tersebut dapat dihitung dari hubungan-hubungan persamaan 9.1, 9.2 dan 9.3 berikut ini :

$$
I K T=\sum_{i=1}^{r} \sum_{j=1}^{n} X_{i j}^{2}-\frac{T^{2}}{n r}
$$

$(9.1)$

$$
\begin{gathered}
J K B=\frac{\sum_{i=1}^{r} T_{i}^{2}}{n}-\frac{T^{2}}{n r} \\
(9.2) \\
J K G=J K T-J K B
\end{gathered}
$$

Nilai dugaan populasi diperoleh dengan cara menguraikan jumlah kuadrat total dibagi dengan derajat bebasnya. Nilai dugaan ini merupakan nilai dugaan tak nias bagi varian populasi bila hipotesis nol benar tanpa memperhatikan pengelompokkannya yang mempunyai derajat bebas (nr-1). 


$$
S^{2}=\frac{\sum_{i-1}^{r} \sum_{j=1}^{n}\left(X_{i j}-X\right)^{2}}{n r-1}=\frac{J K T}{n r-1}
$$

Sedangkan besarnya variansi antar baris diperoleh dengan membagi jumlah kuadrat antar rata-rata baris dengan derajat bebas $(\mathrm{r}-1)$.

$$
S_{1}^{2}=\frac{n \sum_{i=1}^{r}\left(\overline{\left.\bar{X}_{l}-\bar{X}\right)^{2}}\right.}{r-1}=\frac{J K B}{r-1}
$$

Adapun ragam galat diperoleh dari jumlah kuadrat galat dibagi derajat bebas $r(n-1)$. Nilai dugaan bersifat tidak bias baik Ho benar atau salah, dinyatakan dalam bentuk :

$$
S_{2}^{2}=\frac{\sum_{i-1}^{r} \sum_{j=1}^{n}\left(X_{i j}-X\right)^{2}}{r(n-1)}=\frac{J K G}{r(n-1)}
$$

Pengujian hipotesis nol benar didasarkan atas perbandingan nilai dugaan ragam/variansi antara rata-rata baris dengan ragam/variansi galatnya.

$$
F=\frac{s_{1}^{2}}{S_{2}^{2}}
$$


Dimana nilai $F$ merupakan nilai peubah acak distribusi-F dengan derajat bebas pembilang ( $\mathrm{r}-1)$ dan derajat bebas penyebut $\mathrm{r}(\mathrm{n}-1)$. Bila Ho benar, pengujian satu arah pada taraf nyata $\alpha$ dengan daerah penerimaan adalah $\mathrm{F} \leq \mathrm{F} \alpha(\mathrm{df} 1 ; \mathrm{df} 2)$ dan daerah penolakan $F>F \alpha(\mathrm{df} 1 ; \mathrm{df} 2)$. Untuk mempermudah perhitungan, pengujian hipotesis ditampilkan dalam bentuk tabel analisis variansi sebagai berikut : 
Tabel 9.2. Nilai pengamatan analisis ragam satu arah

\begin{tabular}{l|c|c|c|c}
$\begin{array}{l}\text { umber } \\
\text { arians }\end{array}$ & $\begin{array}{l}\text { Jumlah } \\
\text { kuadrat }\end{array}$ & $\begin{array}{c}\text { Derajat } \\
\text { Bebas }\end{array}$ & Ragam & F Rasio \\
\hline ntar baris & JKB & $(\mathrm{r}-1)$ & $S_{1}^{2}=\frac{J K B}{r-1}$ \\
\hline alat/error & JKG & $\mathrm{r}(\mathrm{n}-1)$ & $S_{2}^{2}=\frac{J K G}{r(n-1)}$ \\
\hline otal & $\mathrm{JKT}$ & $(\mathrm{nr}-1)$ & \\
\hline
\end{tabular}


Contoh:

- Sebuah pabrik lampu memproduksi 4 macam lampu pijar dengan daya masing-masing $10 \mathrm{~W}, 15 \mathrm{~W}, 20 \mathrm{~W}$, san $25 \mathrm{~W}$ dan diinginkan untuk menguji apakah ada perbedaan umur pemakaian. Untuk menguji masingmasing diambil sampel acak 6 buah lampu. Dapat dikatakan bahwa tidak ada perbedaan umur pakai diantara 4 macam lampu tersebut. Ujilah dengan taraf nyata 0,05 .

\begin{tabular}{l|l|l|r|r|r|r|}
\hline Lampu & \multicolumn{7}{|c|}{ Lama Pemakaian (dalam hari) } \\
\hline $10 \mathrm{~W}$ & 159 & 150 & 170 & 137 & 181 & 163 \\
\hline $15 \mathrm{~W}$ & 181 & 162 & 201 & 218 & 188 & 190 \\
\hline $20 \mathrm{~W}$ & 176 & 181 & 201 & 165 & 175 & 182 \\
\hline $25 \mathrm{~W}$ & 177 & 162 & 173 & 185 & 171 & 152 \\
\hline
\end{tabular}

Jawab:

$$
I K T=\left(159^{2}+150^{2}+170^{2}+\cdots+152^{2}\right)-\frac{(4200)^{2}}{6(4)}=742.338
$$


$I K B=\frac{\left(960^{2}+1140^{2}+1080^{2}+1020^{2}\right)}{6}-\frac{(4200)^{2}}{6(4)}=738.000-735$.

$>\mathrm{JKG}=\mathrm{JKT}-\mathrm{JKB}=7.338-3.000=4.338$

$>$ Ho: $\mu 1=\mu 2=\mu 3=\mu 4$

H1 : sekurang-kurangnya ada dua nilai rata-rata yang tidak sama.

$>$ Taraf nyata $\alpha=0,05 \rightarrow \mathrm{F} 0,05(3: 20)=3,10$ untuk $\mathrm{r}=4$ dan $\mathrm{n}=6$ dimana df $1=\mathrm{r}-1=3 ;$ df $2=\mathrm{r}(\mathrm{n}-1)=20$

$>$ Daerah penerimaan : Fo $\leq 3,10$ dan daerah penolakan : Fo $>3,10$

$>$ Pengujian Statistik:

\begin{tabular}{l|l|l|l|l}
\hline $\begin{array}{l}\text { Sumber } \\
\text { Variansi }\end{array}$ & $\begin{array}{l}\text { Jumlah } \\
\text { Kuadrat }\end{array}$ & $\begin{array}{l}\text { Derajat } \\
\text { Bebas }\end{array}$ & Variansi & F-Rasio \\
\hline Antar Baris & 3.000 & 3 & $3000 / 3=1000$ & \multirow{2}{*}{$1000 / 216,9=4,61$} \\
\hline Galat & 4.338 & 20 & $4338 / 20=216,9$ & \\
\hline Total & 7.338 & 23 & $1.216,9$ & \\
\cline { 1 - 3 } & &
\end{tabular}

Karena Fo $=4,61>3,10$ maka hipotesis Ho ditolak.

Artinya umur pakai rata-rata keempat jenis lampu pijar tidak sama.

\subsubsection{Data Tidak Seragam}

Pada pengujian ragam dengan data yang tidak seragam (sama) maka perhitungan yang digunakan adalah:

Variansi antar kelompok : 
$S_{\bar{x}}^{2}=\frac{1}{(r-1)} \sum_{j=1}^{r}\left(\bar{X}_{x}-\bar{X}\right)^{2}$

(9.8)

Variansi Dalam Sampel

$S_{i}^{2}=\frac{1}{(n i-1)} \sum_{j=1}^{n}\left(X_{i j}-\overline{X_{i}}\right)^{2}$

(9.9)

Variansi Gabungan

$S_{p}^{2}=\frac{(n 1-1) S_{1}^{2}+(n 2-1) S_{2}^{2}+(n 3-1) S_{3}^{2}}{n 1+n 2+n 3-3}$

(9.10)

Uji Statistik distribusi -F

$F=\frac{\text { variansi antar kelompok }}{\text { Variansi dalam sampel }}=\frac{n S_{\bar{x}}^{2}}{S_{p}^{2}}$

(Wibisono,2009)

Contoh:

Perusahaan rokok Jarum memproduksi rokoknya di empat lokasi yang berbeda. Hasil pengamatan secara acak menunjukkan bahwa rata-rata kandungan tar per bungkus rokok seperti tabel dibawah ini. Lakukanlah analisis varian dengan taraf nyata $1 \%$. Ujilah bahwa rata-rata kandungan tar 
per bungkus sama untuk rokok yang diproduksi di empat lokasi yang berbeda.

\begin{tabular}{l|l|l|l|l|l|l|l}
\hline Lokasi Pabrik & \multicolumn{6}{|c|}{ Kandungan Tar per bungkus (mg) } & Pembobc \\
\hline Tangerang & 25 & 27 & 26,5 & 27,5 & 24,5 & 25,5 & $\mathrm{n} 1=6$ \\
\hline Sidoarjo & 27,8 & 26,9 & 26,8 & 28,3 & 30,2 & & $\mathrm{n} 2=5$ \\
\hline Surabaya & 31,5 & 29,6 & 28,9 & & & & $\mathrm{n} 3=3$ \\
\hline Bandung & 22,9 & 24,5 & 27,1 & 25,5 & & & $\mathrm{n} 4=4$ \\
\hline
\end{tabular}

Jawab:

\section{Menghitung rata-rata}

Rata - rata kandungan tar $\bar{X}=\frac{n(X l)}{\sum n i}=\frac{6(26)+5(28)+3(30)+4(25)}{(6+5+3+4)}=27 \mathrm{~m}$

* Menghitung Variansi Antar Kelompok

Untuk ukuran sampel yang tidak seragam, penduga variansi antar kelompok tidak dikalilan dengan $\mathrm{n}$, namun dilakukan faktor pembobot. Jadi $\mathrm{r}=$ kelompok.

$$
\begin{aligned}
& S_{\bar{X}}^{2}=\frac{1}{(r-1)} \sum_{j=1}^{r}\left(\bar{X}_{\mathrm{u}}-\bar{X}\right)^{2} \\
& S_{\bar{X}}^{2}=\frac{6(26-27)^{2}+5(28-27)^{2}+3(30-27)^{2} 4(25-27)^{2}}{(4-1)}=18
\end{aligned}
$$


Menghitung Variansi dalam Sampel

$$
\begin{aligned}
& S_{i}^{2}=\frac{1}{(n i-1)} \sum_{j=1}^{n}\left(X_{i j}-\overline{X_{i}}\right)^{2} \\
& S_{1}^{2}=\frac{1}{(6-1)}\left[(25-26)^{2}+(27-26)^{2}+\cdots+(25,5-26)^{2}\right]=1,40
\end{aligned}
$$

\section{* Variansi Gabungan}

Adapun Variansi gabungan $=S_{p}^{2}=\frac{(n 1-1) S_{1}^{2}+(n 2-1) S_{2}^{2}+(n 3-1) S_{3}^{2}}{n 1+n 2+n 3-3}$

$$
S_{p}^{2}=\frac{(6-1) 1,40+(5-1) 1,91+(3-1) 1,81+(4-1) 3,11}{(6+5+3+4)-4}=1,97
$$

* Но: $\mu 1=\mu 2=\mu 3=\mu 4$

H1: sekurang-kurangnya ada dua nilai rata-rata yang tidak sama.

Taraf nyata $\alpha=0,01 \rightarrow \mathrm{F} 0,01(3: 14)=5,56$ untuk $\mathrm{r}=4$ dan $\mathrm{N}=18$, dimana df $1=\mathrm{r}-1=3 ;$ df $2=\mathrm{N}-\mathrm{r}=14$

* Daerah penerimaan : Fo $\leq 5,56$

$$
\text { Daerah penolakan : Fo }>5,56
$$

Pengujian Statistik $-\mathrm{F}=18 / 1,97=9,14$

Kesimpulan, karena Fo = 9,14 > 5,56 maka hipotesis

Ho ditolak. Artinya rokok yang diproduksi di 
empat lokasi memiliki rata-rata kandungan tar yang tidak sama.

\subsection{Uji Homogenitas}

Diasumsikan adanya homogenitas variansi menjelaskan bahwa variansi pada masing masing kelompok sama. Asumsi ini diperlukan agar kombinasi variansi masing-masing kelompok dapat dilakukan. Hipotesis nol pada uji homogenitas variansi Bartlett mensyaratkan bahwa nilai variansi populasi haruslah $\sigma_{1}^{2}=\sigma_{2 . m}^{2}=\sigma_{r}^{2} \quad$ lawan hipotesis alternatifnya $\quad \sigma_{i}^{2} \neq \sigma_{l}^{2}$ untuk beberapa $i \neq 1$. Variansi Gabungan memberikan hasil dugaan gabungan, yaitu :

$$
S_{p}^{2}=\frac{\sum_{i-1}^{r}\left(n_{i}-1\right) S_{1}^{2}}{(N-r)}
$$

$$
\text { Bo }=\frac{1}{S_{p}^{2}}\left[\left(s_{1}^{2}\right)^{n 1-1} \chi\left(s_{2}^{2}\right)^{n 2-1} \chi \ldots x\left(s_{r}^{2}\right)^{n r-1}\right]^{1 / N-r}
$$

Bila ukuran sampel sama $(\mathrm{n} 1=\mathrm{n} 2=\ldots=\mathrm{nr})$ nilai $\mathrm{B} \geq \mathrm{B} \alpha$ $(\mathrm{r} ; \mathrm{n})$ menunjukkan bahwa hipotesis nol diterima pada taraf 
nyata $\alpha$, sehingga disimpulkan bahwa variansi populasi sama. Sebaliknya, jika B < B $\alpha(r ; n)$ menunjukkan bahwa hipotesis alternatif diterima pada taraf nyata $\alpha$, sehingga disimpulkan bahwa variansi populasi tidak semuanya sama. Adapun untuk ukuran sampel tidak sama $(\mathrm{ni} \neq \mathrm{nl}$ untuk beberapa $\mathrm{i} \neq 1$ ) hipotesis nol diterima pada taraf nyata $\alpha$ bila $\mathrm{B} \geq \mathrm{B} \alpha$ (r; $\mathrm{n} 1=\mathrm{n} 2=\ldots=\mathrm{nr})$ dan sebaliknya Hipotesis nol ditolak berarti sekurang-kurangnya ada dua variansi populasi yang tidak sama, sehingga tabel distribusi Bartlet diuraikan sebagai berikut :

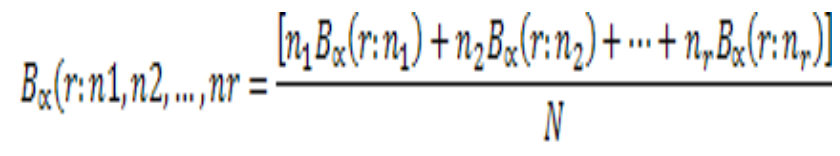

(Wibisono,2009)

\section{Contoh :}

Gunakan uji Bartlet dengan taraf nyata 0,05 untuk menguji hipotesis bahwa variansi ketiga mesin pabrik adalah sama $(\mathrm{r}=3$ dan $\mathrm{N}=15)$.

Jawab :

Menentukan nilai Ho dan $\mathrm{H} 1$

$$
H o=\sigma_{1}^{2}=\sigma_{2}^{2}=\sigma_{3}^{2}
$$


H1: Sekurang-kurangnya ada dua variansi populasi yang tidak sama

Taraf nyata $\alpha=0,05 \rightarrow \mathrm{F} 0,05(2 ; 12)=3,89$ untuk $\mathrm{r}=3$ dan

$\mathrm{N}=15$ dimana df $1=\mathrm{r}-1=2 ; \mathrm{df} 2=(\mathrm{N}-\mathrm{r})=12$.

* Daerah penerimaan : Fo $\geq 3,89$

Daerah penolakan : Fo $<3,89$

Pengujian Statistik

$$
\begin{aligned}
& S_{1}^{2}=13,5 ; S_{2}^{2}=12,5 ; S_{3}^{2}=11,5 ; S_{p}^{2}=12,5 \\
& B o=\frac{\left[(13,5)^{5-1} x(12,5)^{5-1} x(11,5)^{5-1}\right]^{1 /(15-3)}}{12,5}=0,998
\end{aligned}
$$

* Kesimpulan, karena Bo = 0,988 < 0,5762 maka hipotesis Ho ditolak, sehingga dapat disimpulkan bahwa variansi ketiga mesin adalah tidak sama.

\subsection{Analisis Ragam Dua Arah}

Analisis ragam dua arah adalah perluasan dari analisis ragam satu arah untuk pengamatan berpasangan yang tidak melibatkan dua contoh pengamatan saja tetapi tiga atau lebih. Pada analisis ragam dua arah kita tidak lagi menyebut pengamatan berpasangan karena tiga atau lebih contoh mempunyai kesempatan yang sama untuk dibandingkan dalam pengamatan yang diulang beberapa kali. Dengan kata lain perbedaan mendasar dari analisis ragam satu arah dan 
dua arah adalah analisis ragam satu arah hanya mempertimbangkan satu faktor yang menimbulkan variasi, sedangkan analisis ragam dua arah mempertimbangkan dua faktor yang menimbulkan variasi. Dua faktor variasi yang dipertimbangkan adalah keragaman antar contoh dan keragaman antar pengamatan atau ulangan. Menurut Yitnosumarto (1990), model analisis ragam dua arah dapat dinyatakan sebagaimana persamaan 9.1 sebagai berikut :

$$
\begin{array}{r}
X_{i}=\mu+\gamma_{i}+\beta_{j}+\varepsilon_{i j}, \\
\qquad i=1,2, \ldots, n ; j=1,2, \ldots, k
\end{array}
$$

di mana :

$X_{\mathrm{ij}}=$ pengamatan pada baris ke- $i$ dan kolom ke- $j$

$\mu=$ nilai tengah umum

$\gamma_{i}=$ pengaruh baris ke- $i$

$\beta_{\mathrm{j}}=$ pengaruh kolom ke $-j$

$\varepsilon_{i j}=$ sisa pengaruh untuk pengamatan baris ke-i dan kolom ke$j$ 


\subsubsection{Analisis Ragam Dua Arah}

Nilai pengamatan analisis ragam dua arah apabila disajikan dalam bentuk tabel, dinyatakan sebagaimana tabel 9.3 sebagai berikut :

Tabel 9.3. Nilai pengamatan analisis ragam dua arah

\begin{tabular}{|c|c|c|c|c|c|}
\hline \multirow{2}{*}{ Baris } & \multicolumn{4}{|c|}{ Kolom } & Total \\
\hline & 1 & 2 & $\ldots$ & $k$ & \multirow{4}{*}{$\begin{array}{l}\sum_{j=1}^{k} X_{1 j} \\
\sum_{j=1}^{k} X_{2 j}\end{array}$} \\
\hline 1 & $\mathrm{X}_{11}$ & $\mathrm{X}_{12}$ & $\ldots$ & $\mathrm{X}_{1 \mathrm{k}}$ & \\
\hline 2 & $\mathrm{X}_{21}$ & $X_{22}$ & $\ldots$ & $X_{2 k}$ & \\
\hline$\ldots$ & $\ldots$ & $\ldots$ & & $\ldots$ & \\
\hline$n$ & $X_{n 1}$ & $X_{n 2}$ & $\ldots$ & $\mathrm{X}_{\mathrm{nk}}$ & $\sum_{j=1}^{k} X_{i j}$ \\
\hline
\end{tabular}

(Yitnosumarto,1990)

Analisis ragam dua arah mempertimbangkan dua faktor yaitu keragaman antar contoh (antar baris) dan keragaman antar pengamatan atau ulangan (antar kolom). Sehingga susunan tabel analisis ragam dua arah menurut 
Yitnosumarto (1990), dapat dinyatakan pada tabel 9.4sebagai berikut :

Tabel 9.4 Tabel Analisis Ragam Dua Arah

\begin{tabular}{|c|cccc|}
\hline $\begin{array}{c}\text { Sumber } \\
\text { Keragaman } \\
\text { (SK) }\end{array}$ & db & JK & KT & $\mathbf{F}$ \\
\hline \multirow{2}{*}{ Baris } & $(\mathrm{n}-1)$ & $\sum_{i=1}^{n}\left(\sum_{j=1}^{k} X_{i j}\right)^{2} / k-F K$ & $\begin{array}{c}\mathrm{JK}_{\text {Baris }} /( \\
\mathrm{n}-1)\end{array}$ & $\begin{array}{c}\mathrm{KT}_{\text {Baris }} / \\
\mathrm{KT}_{\mathrm{G}}\end{array}$ \\
\cline { 2 - 5 } Kolom & $(\mathrm{k}-1)$ & $\sum_{j=1}^{k}\left(\sum_{i=1}^{n} X_{i j}\right)^{2} / n-F K$ & $\begin{array}{c}\mathrm{JK}_{\text {kolom }} / \\
(\mathrm{k}-1)\end{array}$ & $\begin{array}{c}\mathrm{KT}_{\text {Kolom }} / \\
\mathrm{KT}_{\mathrm{G}}\end{array}$ \\
\cline { 2 - 5 } Galat/Sisaan & $(\mathrm{n}-1)(\mathrm{k}-1)$ & $\begin{array}{c}\mathrm{JK}_{\mathrm{G}}=\mathrm{JK}_{\text {Total- }} \mathrm{JK}_{\text {Baris- }} \\
\mathrm{JK}_{\mathrm{kolom}}\end{array}$ & $\begin{array}{c}\mathrm{JK}_{\mathrm{G}} /(\mathrm{n}- \\
1)(\mathrm{k}-1)\end{array}$ \\
\cline { 2 - 5 } Total & $\mathrm{nk}-1$ & $\sum_{i=1}^{n} \sum_{j=1}^{k} X_{i j}{ }^{2}-F K$ & \\
\hline
\end{tabular}

Keterangan :

FK adalah faktor koreksi yang dinyatakan sebagaimana persamaan 9.4 sebagai berikut :

$$
F K=\left(\sum_{j=1}^{k} \sum_{i=1}^{n} X_{i j}\right)^{2} / n k
$$

Menurut Walpole (1995), pada analisis ragam dua arah terdapat 6 langkah yang harus dilakukan, langkah-langkah tersebut antara lain adalah sebagai berikut : 


\section{Menentukan Hipotesis}

Terdapat dua hipotesis dalam analisis ragam dua arah yaitu hipotesis untuk baris dan hipotesis untuk kolom
a. Hipotesis untuk baris

$H_{0}: \gamma_{1}=\gamma_{2}=\gamma_{3}=0$

$H_{1}$ : Paling tidak ada satu $\gamma_{i} \neq 0$

a. Hipotesis untuk kolom

$H_{0}: \beta_{1}=\beta_{2}=\beta_{3}=0$

$H_{1}:$ Paling tidak ada satu $\beta_{i} \neq 0$

2. Menentukan tingkat signifikansi $(\alpha)$ dan nilai F tabel

Tingkat signifikansi adalah tingkat kesalahan yang mungkin dilakukan dalam proses analisis, nilai $\alpha$ yang pada umumnya paling sering digunakan adalah 5\%,10\% dan $15 \%$.

Nilai $F$ tabel bergantung pada tingkat signifikansi dan derajat bebas $(\mathrm{db})$ pada setiap baris, kolom dan db galat. Nilai Ftabel dinyatakan sebagai berikut :

a. Nilai $\mathrm{F}$ tabel untuk baris ; F ( $\alpha$;db baris ; db galat) 
b. Nilai F tabel untuk kolom ; F ( $\alpha$;db kolom ; db galat)

3. Menentukan kriteria pengujian

Tolak $\mathrm{H}_{0}$ jika $\mathrm{F}$ hitung $>\mathrm{F}$ tabel

Terima $\mathrm{H}_{0}$ jika $\mathrm{F}$ hitung $\leq \mathrm{F}$ tabel

4. Menghitung tabel analisis ragam dua arah

Tabel analisis ragam dua arah disajikan pada tabel 9.2 dengan persamaan-persamaan penyusun tabel analisis ragam tersebut. Sebelum menyusun tabel analisis ragam dua arah terlebih dahulu dihitung komponen-komponen penyusun tabel analisis ragam seperti faktor koreksi dan Jumlah Kuadrat masing-masing sumber keragaman

5. Membuat Keputusan

Keputusan yang diambil adalah tolak $\mathrm{H}_{0}$ atau terima $\mathrm{H}_{0}$. Hal ini tergantung pada hasil kriteria pengujian yang dilakukan

6. Membuat Kesimpulan 
Kesimpulan dibuat berdasarkan hasil keputusan yang telah diambil. Apabila kita memutuskan untuk menolak $\mathrm{H}_{0}$ maka dapat disimpulkan bahwa terdapat perbedaan yang signifikan pada komponen baris atau kolom, sebaliknya apabila kita memutuskan untuk menerima $\mathrm{H}_{0}$ maka dapat disimpulkan bahwa tidak terdapat perbedaan yang signifikan pada komponen baris atau kolom.

\section{Contoh:}

Untuk lebih memahami tentang uraian materi analisis ragam dua arah yang telah dijelaskan berikut ini diberikan contoh kasus analisis ragam dua arah

Seorang dosen ingin meneliti efektifitas metode penilaian terhadap nilai KUIS mahasiswa pada 3 matakuliah yag telah diajarkan. Terdapat 3 metode penilaian yang digunakan yaitu tes tulis (A1), tes lisan (A2) serta tes tulis dan tes lisan (A3). Data nilai rata-rata kelas pada 3 matakuliah yang menjadi fokus penelitian dengan 3 jenis metode penilaian disajikan pada tabel 9.3 sebagai berikut : 
Tabel 9.5 Data nilai rata-rata kelas pada 3 matakuliah

\begin{tabular}{c|ccc}
\hline \multirow{2}{*}{$\begin{array}{c}\text { Metode } \\
\text { Penilaian }\end{array}$} & \multicolumn{3}{|c}{ Matakuliah } \\
\cline { 2 - 4 } & $\begin{array}{c}\text { Statistika } \\
\text { Dasar }\end{array}$ & $\begin{array}{c}\text { Matematika } \\
\text { Dasar }\end{array}$ & $\begin{array}{c}\text { Matematika } \\
\text { Diskrit }\end{array}$ \\
\hline A1 & 83 & 79 & 79,5 \\
A2 & 87 & 80,5 & 82 \\
A3 & 85 & 81,5 & 83,5 \\
\hline
\end{tabular}

Dengan menggunakan analisis ragam dua arah tentukan apakah ada perbedaan antar metode penilaian dan antar matakuliah atau tidak?

Seperti yang telah dijelaskan diawal terdapat 6 langkah dalam analisis ragam dua arah. Berikut adalah tahapan yang dilakukan dalam analisis ragam dua arah :

\section{Menentukan Hipotesis}

a. Hipotesis untuk metode penilaian (baris)

$H_{0}: \gamma_{1}=\gamma_{2}=\gamma_{3}=0$

$H_{1}:$ Paling tidak ada satu $\gamma_{i} \neq 0$ 
b. Hipotesis untuk matakuliah (kolom)

$H_{0}: \beta_{1}=\beta_{2}=\beta_{3}=0$

$H_{1}$ : Paling tidak ada satu $\beta_{i} \neq 0$

2. Menentukan tingkat signifikansi $(\alpha)$ dan nilai $F$ tabel

Tingkat signifikansi $\alpha=5 \%=0,05$

a. Nilai $\mathrm{F}$ tabel untuk baris ; F ( $\alpha$;db baris ; db galat) dimana $\mathrm{db} 1=3-1=2$ dan $\mathrm{db} 2=2 \times 2=4$

$$
\mathrm{F}(0,05 ; 2 ; 4)=19,25
$$

b. Nilai $\mathrm{F}$ tabel untuk kolom ; F $(\alpha ; \mathrm{db}$ kolom ; db galat $)$ dimana $\mathrm{db} 1=3-1=2$ dan $\mathrm{db} 2=2 \times 2=4$

$$
\mathrm{F}(0,05 ; 2 ; 4)=19,25
$$

3. Menentukan kriteria pengujian

Tolak $\mathrm{H}_{0}$ jika $\mathrm{F}$ hitung $>\mathrm{F}$ tabel

Terima $\mathrm{H}_{0}$ jika $\mathrm{F}$ hitung $\leq \mathrm{F}$ tabel

4. Menghitung tabel analisis ragam dua arah

Komponen- komponen analisis ragam dua arah dihitung berdasarkan persamaan yang disajikan pada tabel 9.4. 
Sebelum menyusun tabel analisis ragam dua arah terlebih dahulu dihitung komponen-komponen penyusun tabel analisis ragam dua arah, yang dinyatakan sebagai berikut :

\begin{tabular}{c|ccc|c}
\hline & \multicolumn{3}{|c|}{ Matakuliah } & \\
\cline { 2 - 5 } Metode & Statistika & Matematika & Matematika & \\
Penilaian & Dasar & Dasar & Diskrit & Total \\
\hline A1 & 83 & 79 & 79,5 & 241,5 \\
A2 & 87 & 80,5 & 82 & 249,5 \\
A3 & 85 & 81,5 & 83,5 & 250 \\
\hline Total & 255 & 241 & 245 & 741 \\
\hline
\end{tabular}

a. Faktor Koreksi

$$
\begin{aligned}
F K & =\left(\sum_{j=1}^{k} \sum_{i=1}^{n} X_{i j}\right)^{2} / n k \\
& =(741)^{2} /(3 \times 3)=61009
\end{aligned}
$$

b. Jumlah Kuadrat masing-masing sumber keragaman

$$
\begin{aligned}
J K_{\text {Total }} & =\sum_{i=1}^{n} \sum_{j=1}^{k} X_{i j}{ }^{2}-F K \\
& =\left(83^{2}+79^{2}+\ldots+81,5^{2}+83,5^{2}\right)-61009=54 \\
J K_{M . \text { Penilaian }} & =\sum_{i=1}^{n}\left(\sum_{j=1}^{k} X_{i j}\right)^{2} / k-F K \\
& =\frac{241,5^{2}+249,5^{2}+250^{2}}{3}-61009=15,17
\end{aligned}
$$




$$
\begin{aligned}
J K_{\text {Matkul }}= & \sum_{j=1}^{k}\left(\sum_{i=1}^{n} X_{i j}\right)^{2} / n-F K \\
& =\frac{255^{2}+241^{2}+245^{2}}{3}-61009=34,67
\end{aligned}
$$

$$
\begin{aligned}
\mathrm{JK}_{\mathrm{G}} & =\mathrm{JK}_{\text {Total- }} \mathrm{JK}_{\mathrm{M} . \mathrm{P}^{-}} \mathrm{JK}_{\text {Matkul }} \\
& =54-15,17-34,67=4,16
\end{aligned}
$$

Berdasarkan hasil perhitungan faktor koreksi dan jumlah kuadrat sebagai komponen tabel analisis ragam maka dapat disusun tabel analisis ragam yang dinyatakan sebagaimana tabel 9.6 berikut :

Tabel 9.6 Tabel analisis ragam dua arah untuk data nilai ratarata kelas pada 3 matakuliah

\begin{tabular}{|c|cccc|}
\hline $\begin{array}{c}\text { Sumber } \\
\text { Keragaman (SK) }\end{array}$ & db & JK & KT & F \\
\hline MP & 2 & 15,17 & 7,585 & 7,29 \\
Matakuliah & 2 & 34,67 & 17,335 & 16,67 \\
\cline { 2 - 5 } Galat/Sisaan & 4 & 4,16 & 1,04 & \\
\cline { 2 - 5 } Total & 8 & 54 & & \\
\cline { 2 - 5 } & & & & \\
\hline
\end{tabular}


5. Membuat Keputusan

a. Sumber Keragaman Baris (M. Penilaian)

F hitung $(7,29) \leq \mathrm{F}$ tabel $(19,25)$ maka keputusan yang diambil adalah terima $\mathrm{H}_{0}$

b. Sumber Keragaman Kolom (Matakuliah)

F hitung $(17,335) \leq \mathrm{F}$ tabel $(19,25)$ maka keputusan yang diambil adalah terima $\mathrm{H}_{0}$

6. Membuat Kesimpulan

a. Pada SK Baris (metode penilaian) karena keputusan yang diambil adalah terima $\mathrm{H}_{0}$ maka dapat disimpulkan bahwa tidak terdapat perbedaan yang signifikan untuk nilai rata-rata kuis pada setiap jenis metode penilaian yang digunakan.

a. Pada SK kolom (matakuliah) Karena keputusan yang diambil adalah terima $\mathrm{H}_{0}$ maka dapat disimpulkan bahwa tidak terdapat perbedaan yang signifikan untuk nilai rata-rata kuis pada setiap jenis metode penilaian yang digunakan. 


\subsection{Rangkuman}

- Analisis ragam satu arah adalah analisis yang mempertimbangkan satu faktor yang menimbulkan variasi yaitu keragaman antar baris dan keragaman galat.

- Tabel Nilai pengamatan analisis ragam satu arah

\begin{tabular}{|c|c|c|c|c|}
\hline Populasi & $\begin{array}{c}\text { Asumsi } \\
\text { Distribusi }\end{array}$ & $\begin{array}{c}\text { Nilai } \\
\text { Pengamatan }\end{array}$ & Total & $\begin{array}{c}\text { Rata- } \\
\text { rata }\end{array}$ \\
\hline $\begin{array}{l}1 \\
2 \\
. \\
\text { r }\end{array}$ & $\begin{array}{l}\mathrm{N}\left(\mu 1, \sigma^{2}\right) \\
\mathrm{N}\left(\mu 2, \sigma^{2}\right) \\
\ldots \ldots \ldots \ldots \\
\ldots \ldots \ldots \ldots \\
\mathrm{N}\left(\mu \mathrm{r} \sigma^{2}\right.\end{array}$ & $\begin{array}{l}X 1 j(j=1,2, . ., n) \\
X 2 j(j=1,2, . ., n) \\
\ldots \ldots \ldots \ldots \\
\ldots \ldots \ldots \ldots \\
X i j(j=1,2, . ., n)\end{array}$ & $\begin{array}{l}\mathrm{T} 1 \\
\mathrm{~T} 2 \\
\ldots \\
\ldots \\
\mathrm{Tr}\end{array}$ & $\begin{array}{l}\bar{X}_{1} \\
\bar{X}_{2} \\
\cdots \\
\ldots \\
\overline{\bar{X}}_{r}\end{array}$ \\
\hline \multicolumn{3}{|c|}{$\begin{array}{l}\text { Hipotesis nol : Ho }=\mu 1, \mu 2, \ldots \mu \mathrm{r} \\
\text { Hipotesis alternatif }: \mathrm{H} 1: \mu 1 \neq \mu 1 \text {, untuk beberapa } \\
\mathrm{i} \neq 1\end{array}$} & $\mathrm{~T}$ & $\bar{X}$ \\
\hline
\end{tabular}

- Analisis ragam dua arah adalah analisis yang mempertimbangkan dua faktor yang menimbulkan variasi yaitu keragaman antar contoh (antar baris) dan keragaman antar pengamatan atau ulangan (antar kolom)

- Tabel analisis ragam dua arah dapat dinyatakan sebagai berikut : 


\begin{tabular}{|c|c|c|c|c|}
\hline $\begin{array}{c}\text { Sumber } \\
\text { Keragaman } \\
(\text { SK) }\end{array}$ & db & JK & KT & $\mathbf{F}$ \\
\hline Baris & $(n-1)$ & $\sum_{i=1}^{n}\left(\sum_{j=1}^{k} X_{i j}\right)^{2}$ & $\begin{array}{c}\mathrm{JK}_{\text {Baris }} /( \\
\mathrm{n}-1)\end{array}$ & $\begin{array}{l}\mathrm{KT}_{\text {Baris }} / \\
\mathrm{KT}_{\mathrm{G}}\end{array}$ \\
\hline Kolom & $(\mathrm{k}-1)$ & $\sum_{j=1}^{k}\left(\sum_{i=1}^{n} X_{i j}\right)^{2}$ & $\begin{array}{c}\mathrm{JK}_{\text {kolom }} / \\
(\mathrm{k}-1)\end{array}$ & $\begin{array}{c}\mathrm{KT}_{\text {Kolom }} \\
/ \mathrm{KT}_{\mathrm{G}}\end{array}$ \\
\hline Galat/Sisaan & $(\mathrm{n}-1)(\mathrm{k}-1)$ & $\begin{array}{c}\mathrm{JK}_{\mathrm{G}}=\mathrm{JK}_{\text {Total }^{-}} \\
\mathrm{JK}_{\text {Baris }} \\
\mathrm{JK}_{\text {kolom }}\end{array}$ & $\begin{array}{l}\mathrm{JK}_{\mathrm{G}} /(\mathrm{n}- \\
1)(\mathrm{k}-1)\end{array}$ & \\
\hline Total & nk-1 & $\sum_{i=1}^{n} \sum_{j=1}^{k} X_{i j}{ }^{2}-$ & & \\
\hline
\end{tabular}

\subsection{Latihan}

1. Jelaskan perbedaan mendasar analisis ragam satu arah dan analisis ragam dua arah!

2. Data-data dibawah ini menunjukkan jumlah panenan (Kw/Ha) masing-masing jenis padi varietas IR-32, IR-36 dan VUTR. Ujilah dengan taraf nyata 0,01, apakah ada perbedaan nyata rata-rata produksi ketiga jenis varietas padi tersebut. 


\begin{tabular}{l|l|l|l|l|l|l}
\hline Jenis Padi & \multicolumn{6}{|l}{ Hasil Produksi (Kw/Ha) } \\
\hline IR-32 & 42 & 40 & 35 & 36 & 47 & 40 \\
\hline IR-36 & 39 & 43 & 42 & 46 & 43 & 35 \\
\hline VUTR & 43 & 45 & 42 & 46 & 44 & 35 \\
\hline
\end{tabular}

3. Lakukan analisis ragam dua arah pada data tingkat pemahaman mahasiswa terhadap matakuliah statitika dasar yang diberikan dengan menggunakan 4 teknik pengajaran yang berbeda. Penelitian dilakukan terhadap 8 mahasiswa, pengukuran tingkat pemahaman mahasiswa dilakukan dengan skala 1-10 dan selanjutnya data penelitian disajikan sebagaimana tabel di bawah ini :

\begin{tabular}{c|c|c|c|c|c|c|c|c}
\hline \multirow{2}{*}{ Teknik Pengajaran } & \multicolumn{7}{|c}{ Mahasiwa } \\
\cline { 2 - 9 } & 1 & 2 & 3 & 4 & 5 & 6 & 7 & 8 \\
\hline Teknik Pengajaran 1 & 6 & 7 & 9 & 8 & 8 & 7 & 6 & 5 \\
Teknik Pengajaran 2 & 8 & 8 & 8 & 7 & 9 & 9 & 9 & 8
\end{tabular}




\begin{tabular}{l|l|l|l|l|l|l|l|l} 
Teknik Pengajaran 3 & 5 & 7 & 6 & 7 & 7 & 8 & 6 & 5 \\
Teknik Pengajaran 4 & 7 & 6 & 8 & 5 & 7 & 9 & 8 & 7 \\
\hline
\end{tabular}

\section{Daftar Pustaka}

Walpole, Ronald E. (1995). Pengantar Statistika. Jakarta :

PT. Gramedia Pustaka Utama.

Wibisono, Yusuf (2009)., Metode Statistik. Yogyakarta:

Gadjah Mada Press

Yitnosumarto, Suntoyo. (1990). Dasar-Dasar Statistika.

Jakarta: Rajawali Pers. 


\section{BIODATA PENULIS}

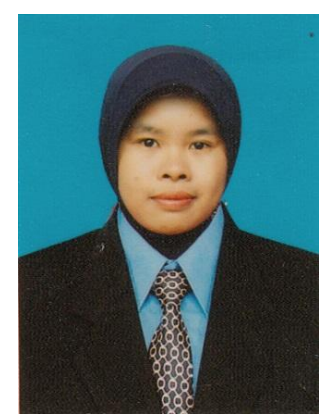

Wiwik Sulistiyowati, S.T., M.T. lahir di Magetan, 16 Agustus 1982. Lulus Sarjana tahun 2005 di Program Studi Teknik Industri, Fakultas Teknologi Industri Universitas Pembangunan Nasiona "Veteran" JAwa Timur Surabaya. Lulus Pasca Sarjana tahun 2008di Program Keahlian Rekayasa Kualitas, Program Studi Teknik Industri, Fakultas Teknologi Industri Institut Teknologi Sepuluh Nopember, Surabaya. Pengalaman kerja di perusahaan manufaktur di Departemen Quality Control selama setahun, kemudian karir pendidikan dimulai pada tahun 2009 di Universitas Muhammadiyah Sidoarjo dengan menjadi dosen tetap dengan jabatan akademik Lektor. Buku yang sudah ditulis adalah Pengendalian Kualitas. Aktif melaksanakan penelitian dan pengabdian kepada masyarakat serta mengikuti seminar dan konferensi di beberapa daerah.

Cindy Cahyaning Astuti., S.Si., M.Si. lahir di Sidoarjo, 14 Juli 1991. Lulus sarjana pada tahun 2013 di Program Studi Statistika Universitas Brawijaya. Lulus Pascasarjana tahun 2015 di Program Studi Statistika

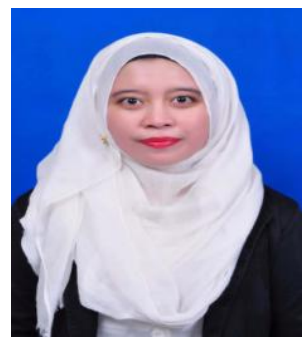
Institut Teknologi Sepuluh Nopember Surabaya dengan skema 
Beasiswa BPPDN-Calon Dosen Kemenristekdikti. Karir bidang pendidikan dimulai sejak tahun 2015 yaitu dengan menjadi dosen tetap di Prodi Pendidikan TIK Fakultas Keguruan dan Ilmu Pendidikan Universitas Muhammadiyah Sidoarjo . 


\section{INDEKS}

A

analisis korelasi, 73, 76-78, 81

analisis regresi :

-linier berganda 73-76, 81

-linier sederhana 73-74, 78, 81

analisis ragam :

-satu arah, 86-92, 100

-dua arah, 92-98, 100

B

batas kelas13, 16-17

D

daftar :

-baris kolom, 5

-kontingensi, 6

-distribusi frekuensi, 6

data :

-interval, 3

-kualitatif, 2

-kuantitatif, 2

-nominal, 2

-ordinal, 3

-rasio, 3

desil 23, 26, 36

diagram :

-baris, 7, 9

-batang, 6, 9

-lambang, 8,9

-lingkaran, 8,9

-peta, 9

distribusi normal 51-56

F

frekuensi : 
-kumulatif 14-16, 18-19, 35

-relatif 14-16, 18-19

G

genta $51-52$

H

hipotesa, 60-63, 69-70

I

intercept 73-76, 78

K

koefisien :

-regresi, 75, 77, 80

-korelasi, 77, 80-81

kurva 51-56

L

lonceng 51,52

M

median, 23-24, 31, 34

modus, 23,25

$\mathbf{P}$

probabilitas $42-46$

$\mathbf{R}$

ragam $23,28-30,51$

range $12,17,19,27,30-31,39$

rata-rata $23-24,29,51$

$\mathbf{S}$

selang kelas, 12-13, 16-17, 19

slope $73-76,78$

simpangan baku 23-24, 32, 51-52

statistik, 1

statistika :

-deskriptif, 1

-inferensia, 2

T 
tabel frekuensi, 13-19

tendensi sentral 51-53

transformasi, 4,57

$\mathbf{U}$

ukuran :

-pemusatan data, 23, 26, 29-30, 33, 39

-penyimpangan data, 23, 27, 30-31, 33, 37, 39

V

variabel :

-acak, 51, 53, 57

-prediktor 73-76, 80-81

-respon 73-76, 80-81 


\section{LAMPIRAN}

Lampiran 1. Tabel Distribusi Normal

Lampiran 2. Tabel Distribusi F 


\section{Areas under the Normal Distribution}

The table gives the curulative probability up to the standardised normal value $?$

i.e. $P[z<z]=\int_{-\infty}^{2} \frac{1}{\sqrt{2 \pi}} \exp \left(-\frac{1}{2} z^{2}\right) d z$

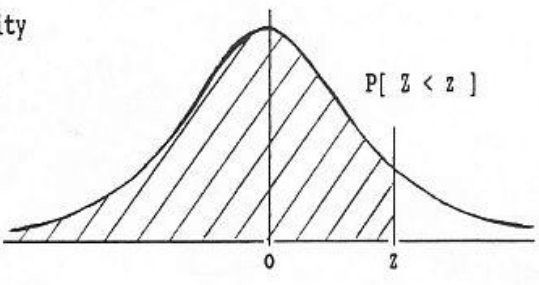

\begin{tabular}{|c|c|c|c|c|c|c|c|c|c|c|}
\hline 2 & 0.00 & 0.01 & 0.02 & 0.03 & 0.04 & 0.05 & 0.06 & 0.07 & 0.08 & 0.09 \\
\hline 0 & 00 & 10 & & & & & & & & \\
\hline 1 & 0.5398 & 5438 & 5478 & 17 & 57 & & & & & \\
\hline 2 & 0.5793 & 32 & 1 & 5910 & 5948 & 5987 & 6 & & & .6 \\
\hline .3 & 0. & 17 & 5 & & 1 & & 6 & & & \\
\hline & 0.6554 & 6591 & .6628 & .6664 & 0.6700 & .67 & .6772 & 0.6 & 0.6844 & \\
\hline 5 & 6915 & 6950 & 5 & 9 & 54 & 8 & 3 & & 90 & \\
\hline 6 & 0.7257 & 16 & 0.7 & .7357 & .7389 & 2 & 4 & & 17 & 0. \\
\hline 7 & 0.7580 & .7611 & 0.7642 & .7673 & 0.7704 & .7 & .7764 & & 823 & \\
\hline 8 & 0.7881 & 79 & 0.7939 & 7967 & 0.7 & & 0.8 & & & \\
\hline & 0.815 & 36 & 0.8212 & .8238 & 1.8 & 1.82 & .8 & & 365 & \\
\hline & 3413 & 8438 & 8 & 35 & 85 & & & & & \\
\hline 1 & 0.86 & 86 & 6 & 18 & .8 & 49 & 0 & & 04 & 0.883 \\
\hline 2 & 0.8849 & .8869 & 0.8888 & 0.8907 & 0.8925 & 14 & .8962 & & 0.8997 & \\
\hline 3 & 0.9032 & .90 & 0.9 & 9082 & 0.9 & & 31 & & 0.9162 & \\
\hline & 0.919 & 9207 & 0.9 & 0.9236 & 0.92 & 0 & 79 & 0. & 0.9306 & \\
\hline & & & 9 & 0 & & & & & & \\
\hline 6 & 0.945 & 94 & 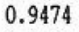 & 2 & 9 & .99 & 5 & & 35 & \\
\hline 7 & 0.9554 & 0.95 & c & 2 & 0.9 & & & & & \\
\hline & 0.964 & 0.9 & 0 & .96 & 0.9 & & & & & \\
\hline & 0.971 & 97 & $0.9^{\prime}$ & 97 & 0.97 & & & & 1 & \\
\hline & & & & & & & & & & \\
\hline & 0.982 & 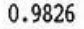 & 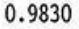 & 34 & 38 & 0.9 & 6 & & & \\
\hline & 0.98 & 98 & c & 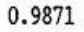 & 0.9 & 0. & & & & \\
\hline & & & & & & & & & & \\
\hline & 0.991 & 0.992 & 0.99 & 0.9924 & 0.99 & .99 & 0.9 & 0 & 9934 & \\
\hline & & 9 & & 3 & 0. & & & & & \\
\hline & 0. & 0 & & & 0. & & & & & \\
\hline & 0.99 & 9 & c & 0. & 0.9 & 0. & 0. & & 73 & \\
\hline & & & & & & & & & & \\
\hline & 0.9981 & 0.9982 & 0.9982 & 0.9983 & 0.9984 & 0.9984 & 0.9985 & 0.9985 & 0.9986 & \\
\hline 2 & & & & & & & & & & \\
\hline & & & 0 & & & & & & & \\
\hline
\end{tabular}




\title{
Titik Persentase Distribusi F Probabilita $=0.01$
}

\author{
Diproduksi oleh: Junaidi \\ http://junaidichaniago.wordpress.com
}


Titik Persentase Distribusi F untuk Probabilita $=0,01$

\begin{tabular}{|c|c|c|c|c|c|c|c|c|c|c|c|c|c|c|c|}
\hline \multirow{2}{*}{$\begin{array}{l}\text { df untuk } \\
\text { penyebut } \\
\text { (N2) }\end{array}$} & \multicolumn{15}{|c|}{ df untuk pembilang (N1) } \\
\hline & 1 & 2 & 3 & 4 & 5 & 6 & 7 & 8 & 9 & 10 & 11 & 12 & 13 & 14 & 15 \\
\hline 1 & 4052 & 4999 & 5403 & 5625 & 5764 & 5859 & 5928 & 5981 & 6022 & 6056 & 6083 & 6106 & 6126 & 6143 & 6157 \\
\hline 2 & 98.50 & 99.00 & 99.17 & 99.25 & 99.30 & 99.33 & 99.36 & 99.37 & 99.39 & 99.40 & 99.41 & 99.42 & 99.42 & 99.43 & 99.43 \\
\hline 3 & 34.12 & 30.82 & 29.46 & 28.71 & 28.24 & 27.91 & 27.67 & 27.49 & 27.35 & 27.23 & 27.13 & 27.05 & 26.98 & 26.92 & 26.87 \\
\hline 4 & 21.20 & 18.00 & 16.69 & 15.98 & 15.52 & 15.21 & 14.98 & 14.80 & 14.66 & 14.55 & 14.45 & 14.37 & 14.31 & 14.25 & 14.20 \\
\hline 5 & 16.26 & 13.27 & 12.06 & 11.39 & 10.97 & 10.67 & 10.46 & 10.29 & 10.16 & 10.05 & 9.96 & 9.89 & 9.82 & 9.77 & 9.72 \\
\hline 6 & 13.75 & 10.92 & 9.78 & 9.15 & 8.75 & 8.47 & 8.26 & 8.10 & 7.98 & 7.87 & 7.79 & 7.72 & 7.66 & 7.60 & 7.56 \\
\hline 7 & 12.25 & 9.55 & 8.45 & 7.85 & 7.46 & 7.19 & 6.99 & 6.84 & 6.72 & 6.62 & 6.54 & 6.47 & 6.41 & 6.36 & 6.31 \\
\hline 8 & 11.26 & 8.65 & 7.59 & 7.01 & 6.63 & 6.37 & 6.18 & 6.03 & 5.91 & 5.81 & 5.73 & 5.67 & 5.61 & 5.56 & 5.52 \\
\hline 9 & 10.56 & 8.02 & 6.99 & 6.42 & 6.06 & 5.80 & 5.61 & 5.47 & 5.35 & 5.26 & 5.18 & 5.11 & 5.05 & 5.01 & 4.96 \\
\hline 10 & 10.04 & 7.56 & 6.55 & 5.99 & 5.64 & 5.39 & 5.20 & 5.06 & 4.94 & 4.85 & 4.77 & 4.71 & 4.65 & 4.60 & 4.56 \\
\hline 11 & 9.65 & 7.21 & 6.22 & 5.67 & 5.32 & 5.07 & 4.89 & 4.74 & 4.63 & 4.54 & 4.46 & 4.40 & 4.34 & 4.29 & 4.25 \\
\hline 12 & 9.33 & 6.93 & 5.95 & 5.41 & 5.06 & 4.82 & 4.64 & 4.50 & 4.39 & 4.30 & 4.22 & 4.16 & 4.10 & 4.05 & 4.01 \\
\hline 13 & 9.07 & 6.70 & 5.74 & 5.21 & 4.86 & 4.62 & 4.44 & 4.30 & 4.19 & 4.10 & 4.02 & 3.96 & 3.91 & 3.86 & 3.82 \\
\hline 14 & 8.86 & 6.51 & 5.56 & 5.04 & 4.69 & 4.46 & 4.28 & 4.14 & 4.03 & 3.94 & 3.86 & 3.80 & 3.75 & 3.70 & 3.66 \\
\hline 15 & 8.68 & 6.36 & 5.42 & 4.89 & 4.56 & 4.32 & 4.14 & 4.00 & 3.89 & 3.80 & 3.73 & 3.67 & 3.61 & 3.56 & 3.52 \\
\hline 16 & 8.53 & 6.23 & 5.29 & 4.77 & 4.44 & 4.20 & 4.03 & 3.89 & 3.78 & 3.69 & 3.62 & 3.55 & 3.50 & 3.45 & 3.41 \\
\hline 17 & 8.40 & 6.11 & 5.18 & 4.67 & 4.34 & 4.10 & 3.93 & 3.79 & 3.68 & 3.59 & 3.52 & 3.46 & 3.40 & 3.35 & 3.31 \\
\hline 18 & 8.29 & 6.01 & 5.09 & 4.58 & 4.25 & 4.01 & 3.84 & 3.71 & 3.60 & 3.51 & 3.43 & 3.37 & 3.32 & 3.27 & 3.23 \\
\hline 19 & 8.18 & 5.93 & 5.01 & 4.50 & 4.17 & 3.94 & 3.77 & 3.63 & 3.52 & 3.43 & 3,36 & 3.30 & 3.24 & 3.19 & 3.15 \\
\hline 20 & 8.10 & 5.85 & 4.94 & 4.43 & 4.10 & 3.87 & 3.70 & 3.56 & 3.46 & 3.37 & 3.29 & 3.23 & 3.18 & 3.13 & 3.09 \\
\hline 21 & 8.02 & 5.78 & 4.87 & 4.37 & 4.04 & 3.81 & 3.64 & 3.51 & 3.40 & 3.31 & 3.24 & 3.17 & 3.12 & 3.07 & 3.03 \\
\hline 22 & 7.95 & 5.72 & 4.82 & 4.31 & 3.99 & 3.76 & 3.59 & 3.45 & 3.35 & 3.26 & 3.18 & 3.12 & 3.07 & 3.02 & 2.98 \\
\hline 23 & 7.88 & 5.66 & 4.76 & 4.26 & 3.94 & 3.71 & 3.54 & 3.41 & 3.30 & 3.21 & 3.14 & 3.07 & 3.02 & 2.97 & 2.93 \\
\hline 24 & 7.82 & 5.61 & 4.72 & 4.22 & 3.90 & 3.67 & 3.50 & 3.36 & 3.26 & 3.17 & 3.09 & 3.03 & 2.98 & 2.93 & 2.89 \\
\hline 25 & 7.77 & 5.57 & 4.68 & 4.18 & 3.85 & 3.63 & 3.46 & 3.32 & 3.22 & 3.13 & 3.06 & 2.99 & 2.94 & 2.89 & 2.85 \\
\hline 26 & 7.72 & 5.53 & 4.64 & 4.14 & 3.82 & 3.59 & 3.42 & 3.29 & 3.18 & 3.09 & 3.02 & 2.96 & 2.90 & 2.86 & 2.81 \\
\hline 27 & 7.68 & 5.49 & 4.60 & 4.11 & 3.78 & 3.56 & 3.39 & 3.26 & 3.15 & 3.06 & 2.99 & 2.93 & 2.87 & 2.82 & 2.78 \\
\hline 28 & 7.64 & 5.45 & 4.57 & 4.07 & 3.75 & 3.53 & 3.36 & 3.23 & 3.12 & 3.03 & 2.96 & 2.90 & 2.84 & 2.79 & 2.75 \\
\hline 29 & 7.60 & 5.42 & 4.54 & 4.04 & 3.73 & 3.50 & 3.33 & 3.20 & 3.09 & 3.00 & 2.93 & 2.87 & 2.81 & 2.77 & 2.73 \\
\hline 30 & 7.56 & 5.39 & 4.51 & 4.02 & 3.70 & 3.47 & 3.30 & 3.17 & 3.07 & 2.98 & 2.91 & 2.84 & 2.79 & 2.74 & 2.70 \\
\hline 31 & 7.53 & 5.36 & 4.48 & 3.99 & 3.67 & 3.45 & 3.28 & 3.15 & 3.04 & 2.96 & 2.88 & 2.82 & 2.77 & 2.72 & 2.68 \\
\hline 32 & 7.50 & 5.34 & 4.46 & 3.97 & 3.65 & 3.43 & 3.26 & 3.13 & 3.02 & 2.93 & 2.86 & 2.80 & 2.74 & 2.70 & 2.65 \\
\hline 33 & 7.47 & 5.31 & 4.44 & 3.95 & 3.63 & 3.41 & 3.24 & 3.11 & 3.00 & 2.91 & 2.84 & 2.78 & 2.72 & 2.68 & 2.63 \\
\hline 34 & 7.44 & 5.29 & 4.42 & 3.93 & 3.61 & 3.39 & 3.22 & 3.09 & 2.98 & 2.89 & 2.82 & 2.76 & 2.70 & 2.66 & 2.61 \\
\hline 35 & 7.42 & 5.27 & 4.40 & 3.91 & 3.59 & 3.37 & 3.20 & 3.07 & 2.96 & 2.88 & 2.80 & 2.74 & 2.69 & 2.64 & 2.60 \\
\hline 36 & 7.40 & 5.25 & 4.38 & 3.89 & 3.57 & 3.35 & 3.18 & 3.05 & 2.95 & 2.86 & 2.79 & 2.72 & 2.67 & 2.62 & 2.58 \\
\hline 37 & 7.37 & 5.23 & 4.36 & 3.87 & 3.56 & 3.33 & 3.17 & 3.04 & 2.93 & 2.84 & 2.77 & 2.71 & 2.65 & 2.61 & 2.56 \\
\hline 38 & 7.35 & 5.21 & 4.34 & 3.86 & 3.54 & 3.32 & 3.15 & 3.02 & 2.92 & 2.83 & 2.75 & 2.69 & 2.64 & 2.59 & 2.55 \\
\hline 39 & 7.33 & 5.19 & 4.33 & 3.84 & 3.53 & 3.30 & 3.14 & 3.01 & 2.90 & 2.81 & 2.74 & 2.68 & 2.62 & 2.58 & 2.54 \\
\hline 40 & 7.31 & 5.18 & 4.31 & 3.83 & 3.51 & 3.29 & 3.12 & 2.99 & 2.89 & 2.80 & 2.73 & 2.66 & 2.61 & 2.56 & 2.52 \\
\hline 41 & 7.30 & 5.16 & 4.30 & 3.81 & 3.50 & 3.28 & 3.11 & 2.98 & 2.87 & 2.79 & 2.71 & 2.65 & 2.60 & 2.55 & 2.51 \\
\hline 42 & 7.28 & 5.15 & 4.29 & 3.80 & 3.49 & 3.27 & 3.10 & 2.97 & 2.86 & 2.78 & 2.70 & 2.64 & 2.59 & 2.54 & 2.50 \\
\hline 43 & 7.26 & 5.14 & 4.27 & 3.79 & 3.48 & 3.25 & 3.09 & 2.96 & 2.85 & 2.76 & 2.69 & 2.63 & 2.57 & 2.53 & 2.49 \\
\hline 44 & 7.25 & 5.12 & 4.26 & 3.78 & 3.47 & 3.24 & 3.08 & 2.95 & 2.84 & 2.75 & 2.68 & 2.62 & 2.56 & 2.52 & 2.47 \\
\hline 45 & 7.23 & 5.11 & 4.25 & 3.77 & 3.45 & 3.23 & 3.07 & 2.94 & 2.83 & 2.74 & 2.67 & 2.61 & 2.55 & 2.51 & 2.46 \\
\hline
\end{tabular}


Titik Persentase Distribusi F untuk Probabilita $=0,01$

\begin{tabular}{|c|c|c|c|c|c|c|c|c|c|c|c|c|c|c|c|}
\hline \multirow{2}{*}{$\begin{array}{l}\text { df untuk } \\
\text { penyebut } \\
\text { (N2) }\end{array}$} & \multicolumn{15}{|c|}{ df untuk pembilang (N1) } \\
\hline & 1 & 2 & 3 & 4 & 5 & 6 & 7 & 8 & 9 & 10 & 11 & 12 & 13 & 14 & 15 \\
\hline 46 & 7.22 & 5.10 & 4.24 & 3.76 & 3.44 & 3.22 & 3.06 & 2.93 & 2.82 & 2.73 & 2.66 & 2.60 & 2.54 & 2.50 & 2.45 \\
\hline 47 & 7.21 & 5.09 & 4.23 & 3.75 & 3.43 & 3.21 & 3.05 & 2.92 & 2.81 & 2.72 & 2.65 & 2.59 & 2.53 & 2.49 & 2.44 \\
\hline 48 & 7.19 & 5.08 & 4.22 & 3.74 & 3.43 & 3.20 & 3.04 & 2.91 & 2.80 & 2.71 & 2.64 & 2.58 & 2.53 & 2.48 & 2.44 \\
\hline 49 & 7.18 & 5.07 & 4.21 & 3.73 & 3.42 & 3.19 & 3.03 & 2.90 & 2.79 & 2.71 & 2.63 & 2.57 & 2.52 & 2.47 & 2.43 \\
\hline 50 & 7.17 & 5.06 & 4.20 & 3.72 & 3.41 & 3.19 & 3.02 & 2.89 & 2.78 & 2.70 & 2.63 & 2.56 & 2.51 & 2.46 & 2.42 \\
\hline 51 & 7.16 & 5.05 & 4.19 & 3.71 & 3.40 & 3.18 & 3.01 & 2.88 & 2.78 & 2.69 & 2.62 & 2.55 & 2.50 & 2.45 & 2.41 \\
\hline 52 & 7.15 & 5.04 & 4.18 & 3.70 & 3.39 & 3.17 & 3.00 & 2.87 & 2.77 & 2.68 & 2.61 & 2.55 & 2.49 & 2.45 & 2.40 \\
\hline 53 & 7.14 & 5.03 & 4.17 & 3.70 & 3.38 & 3.16 & 3.00 & 2.87 & 2.76 & 2.68 & 2.60 & 2.54 & 2.49 & 2.44 & 2.40 \\
\hline 54 & 7.13 & 5.02 & 4.17 & 3.69 & 3.38 & 3.16 & 2.99 & 2.86 & 2.76 & 2.67 & 2.60 & 2.53 & 2.48 & 2.43 & 2.39 \\
\hline 55 & 7.12 & 5.01 & 4.16 & 3.68 & 3.37 & 3.15 & 2.98 & 2.85 & 2.75 & 2.66 & 2.59 & 2.53 & 2.47 & 2.42 & 2.38 \\
\hline 56 & 7.11 & 5.01 & 4.15 & 3.67 & 3.36 & 3.14 & 2.98 & 2.85 & 2.74 & 2.66 & 2.58 & 2.52 & 2.47 & 2.42 & 2.38 \\
\hline 57 & 7.10 & 5.00 & 4.15 & 3.67 & 3.36 & 3.14 & 2.97 & 2.84 & 2.74 & 2.65 & 2.58 & 2.51 & 2.46 & 2.41 & 2.37 \\
\hline 58 & 7.09 & 4.99 & 4.14 & 3.66 & 3.35 & 3.13 & 2.96 & 2.83 & 2.73 & 2.64 & 2.57 & 2.51 & 2.45 & 2.41 & 2.36 \\
\hline 59 & 7.08 & 4.98 & 4.13 & 3.65 & 3.34 & 3.12 & 2.96 & 2.83 & 2.72 & 2.64 & 2.56 & 2.50 & 2.45 & 2.40 & 2.36 \\
\hline 60 & 7.08 & 4.98 & 4.13 & 3.65 & 3.34 & 3.12 & 2.95 & 2.82 & 2.72 & 2.63 & 2.56 & 2.50 & 2.44 & 2.39 & 2.35 \\
\hline 61 & 7.07 & 4.97 & 4.12 & 3.64 & 3.33 & 3.11 & 2.95 & 2.82 & 2.71 & 2.63 & 2.55 & 2.49 & 2.44 & 2.39 & 2.35 \\
\hline 62 & 7.06 & 4.96 & 4.11 & 3.64 & 3.33 & 3.11 & 2.94 & 2.81 & 2.71 & 2.62 & 2.55 & 2.49 & 2.43 & 2.38 & 2.34 \\
\hline 63 & 7.06 & 4.96 & 4.11 & 3.63 & 3.32 & 3.10 & 2.94 & 2.81 & 2.70 & 2.62 & 2.54 & 2.48 & 2.43 & 2.38 & 2.34 \\
\hline 64 & 7.05 & 4.95 & 4.10 & 3.63 & 3.32 & 3.10 & 2.93 & 2.80 & 2.70 & 2.61 & 2.54 & 2.48 & 2.42 & 2.37 & 2.33 \\
\hline 65 & 7.04 & 4.95 & 4.10 & 3.62 & 3.31 & 3.09 & 2.93 & 2.80 & 2.69 & 2.61 & 2.53 & 2.47 & 2.42 & 2.37 & 2.33 \\
\hline 66 & 7.04 & 4.94 & 4.09 & 3.62 & 3.31 & 3.09 & 2.92 & 2.79 & 2.69 & 2.60 & 2.53 & 2.47 & 2.41 & 2.36 & 2.32 \\
\hline 67 & 7.03 & 4.94 & 4.09 & 3.61 & 3.30 & 3.08 & 2.92 & 2.79 & 2.68 & 2.60 & 2.52 & 2.46 & 2.41 & 2.36 & 2.32 \\
\hline 68 & 7.02 & 4.93 & 4.08 & 3.61 & 3.30 & 3.08 & 2.91 & 2.78 & 2.68 & 2.59 & 2.52 & 2.46 & 2.40 & 2.36 & 2.31 \\
\hline 69 & 7.02 & 4.93 & 4.08 & 3.60 & 3.29 & 3.08 & 2.91 & 2.78 & 2.68 & 2.59 & 2.52 & 2.45 & 2.40 & 2.35 & 2.31 \\
\hline 70 & 7.01 & 4.92 & 4.07 & 3.60 & 3.29 & 3.07 & 2.91 & 2.78 & 2.67 & 2.59 & 2.51 & 2.45 & 2.40 & 2.35 & 2.31 \\
\hline 71 & 7.01 & 4.92 & 4.07 & 3.60 & 3.29 & 3.07 & 2.90 & 2.77 & 2.67 & 2.58 & 2.51 & 2.45 & 2.39 & 2.34 & 2.30 \\
\hline 72 & 7.00 & 4.91 & 4.07 & 3.59 & 3.28 & 3.06 & 2.90 & 2.77 & 2.66 & 2.58 & 2.50 & 2.44 & 2.39 & 2.34 & 2.30 \\
\hline 73 & 7.00 & 4.91 & 4.06 & 3.59 & 3.28 & 3.06 & 2.89 & 2.77 & 2.66 & 2.57 & 2.50 & 2.44 & 2.38 & 2.34 & 2.29 \\
\hline 74 & 6.99 & 4.90 & 4.06 & 3.58 & 3.28 & 3.06 & 2.89 & 2.76 & 2.66 & 2.57 & 2.50 & 2.43 & 2.38 & 2.33 & 2.29 \\
\hline 75 & 6.99 & 4.90 & 4.05 & 3.58 & 3.27 & 3.05 & 2.89 & 2.76 & 2.65 & 2.57 & 2.49 & 2.43 & 2.38 & 2.33 & 2.29 \\
\hline 76 & 6.98 & 4.90 & 4.05 & 3.58 & 3.27 & 3.05 & 2.88 & 2.75 & 2.65 & 2.56 & 2.49 & 2.43 & 2.37 & 2.33 & 2.28 \\
\hline 77 & 6.98 & 4.89 & 4.05 & 3.57 & 3.26 & 3.05 & 2.88 & 2.75 & 2.65 & 2.56 & 2.49 & 2.42 & 2.37 & 2.32 & 2.28 \\
\hline 78 & 6.97 & 4.89 & 4.04 & 3.57 & 3.26 & 3.04 & 2.88 & 2.75 & 2.64 & 2.56 & 2.48 & 2.42 & 2.37 & 2.32 & 2.28 \\
\hline 79 & 6.97 & 4.88 & 4.04 & 3.57 & 3.26 & 3.04 & 2.87 & 2.75 & 2.64 & 2.55 & 2.48 & 2.42 & 2.36 & 2.32 & 2.27 \\
\hline 80 & 6.96 & 4.88 & 4.04 & 3.56 & 3.26 & 3.04 & 2.87 & 2.74 & 2.64 & 2.55 & 2.48 & 2.42 & 2.36 & 2.31 & 2.27 \\
\hline 81 & 6.96 & 4.88 & 4.03 & 3.56 & 3.25 & 3.03 & 2.87 & 2.74 & 2.63 & 2.55 & 2.47 & 2.41 & 2.36 & 2.31 & 2.27 \\
\hline 82 & 6.95 & 4.87 & 4.03 & 3.56 & 3.25 & 3.03 & 2.87 & 2.74 & 2.63 & 2.54 & 2.47 & 2.41 & 2.35 & 2.31 & 2.27 \\
\hline 83 & 6.95 & 4.87 & 4.03 & 3.55 & 3.25 & 3.03 & 2.86 & 2.73 & 2.63 & 2.54 & 2.47 & 2.41 & 2.35 & 2.30 & 2.26 \\
\hline 84 & 6.95 & 4.87 & 4.02 & 3.55 & 3.24 & 3.02 & 2.86 & 2.73 & 2.63 & 2.54 & 2.47 & 2.40 & 2.35 & 2.30 & 2.26 \\
\hline 85 & 6.94 & 4.86 & 4.02 & 3.55 & 3.24 & 3.02 & 2.86 & 2.73 & 2.62 & 2.54 & 2.46 & 2.40 & 2.35 & 2.30 & 2.26 \\
\hline 86 & 6.94 & 4.86 & 4.02 & 3.55 & 3.24 & 3.02 & 2.85 & 2.73 & 2.62 & 2.53 & 2.46 & 2.40 & 2.34 & 2.30 & 2.25 \\
\hline 87 & 6.94 & 4.86 & 4.02 & 3.54 & 3.24 & 3.02 & 2.85 & 2.72 & 2.62 & 2.53 & 2.46 & 2.40 & 2.34 & 2.29 & 2.25 \\
\hline 88 & 6.93 & 4.85 & 4.01 & 3.54 & 3.23 & 3.01 & 2.85 & 2.72 & 2.62 & 2.53 & 2.46 & 2.39 & 2.34 & 2.29 & 2.25 \\
\hline 89 & 6.93 & 4.85 & 4.01 & 3.54 & 3.23 & 3.01 & 2.85 & 2.72 & 2.61 & 2.53 & 2.45 & 2.39 & 2.34 & 2.29 & 2.25 \\
\hline 90 & 6.93 & 4.85 & 4.01 & 3.53 & 3.23 & 3.01 & 2.84 & 2.72 & 2.61 & 2.52 & 2.45 & 2.39 & 2.33 & 2.29 & 2.24 \\
\hline
\end{tabular}

Diproduksi oleh: Junaidi (http://junaidichaniago.wordpress.com). 2010 
Titik Persentase Distribusi F untuk Probabilita $=0,01$

\begin{tabular}{|c|c|c|c|c|c|c|c|c|c|c|c|c|c|c|c|}
\hline \multirow{2}{*}{$\begin{array}{l}\text { df untuk } \\
\text { penyebut } \\
\text { (N2) }\end{array}$} & \multicolumn{15}{|c|}{ df untuk pembilang (N1) } \\
\hline & 1 & 2 & 3 & 4 & 5 & 6 & 7 & 8 & 9 & 10 & 11 & 12 & 13 & 14 & 15 \\
\hline 91 & 6.92 & 4.85 & 4.00 & 3.53 & 3.23 & 3.01 & 2.84 & 2.71 & 2.61 & 2.52 & 2.45 & 2.39 & 2.33 & 2.28 & 2.24 \\
\hline 92 & 6.92 & 4.84 & 4.00 & 3.53 & 3.22 & 3.00 & 2.84 & 2.71 & 2.61 & 2.52 & 2.45 & 2.38 & 2.33 & 2.28 & 2.24 \\
\hline 93 & 6.92 & 4.84 & 4.00 & 3.53 & 3.22 & 3.00 & 2.84 & 2.71 & 2.60 & 2.52 & 2.44 & 2.38 & 2.33 & 2.28 & 2.24 \\
\hline 94 & 6.91 & 4.84 & 4.00 & 3.53 & 3.22 & 3.00 & 2.84 & 2.71 & 2.60 & 2.52 & 2.44 & 2.38 & 2.33 & 2.28 & 2.24 \\
\hline 95 & 6.91 & 4.84 & 3.99 & 3.52 & 3.22 & 3.00 & 2.83 & 2.70 & 2.60 & 2.51 & 2.44 & 2.38 & 2.32 & 2.28 & 2.23 \\
\hline 96 & 6.91 & 4.83 & 3.99 & 3.52 & 3.21 & 3.00 & 2.83 & 2.70 & 2.60 & 2.51 & 2.44 & 2.38 & 2.32 & 2.27 & 2.23 \\
\hline 97 & 6.90 & 4.83 & 3.99 & 3.52 & 3.21 & 2.99 & 2.83 & 2.70 & 2.60 & 2.51 & 2.44 & 2.37 & 2.32 & 2.27 & 2.23 \\
\hline 98 & 6.90 & 4.83 & 3.99 & 3.52 & 3.21 & 2.99 & 2.83 & 2.70 & 2.59 & 2.51 & 2.43 & 2.37 & 2.32 & 2.27 & 2.23 \\
\hline 99 & 6.90 & 4.83 & 3.99 & 3.51 & 3.21 & 2.99 & 2.83 & 2.70 & 2.59 & 2.51 & 2.43 & 2.37 & 2.32 & 2.27 & 2.22 \\
\hline 100 & 6.90 & 4.82 & 3.98 & 3.51 & 3.21 & 2.99 & 2.82 & 2.69 & 2.59 & 2.50 & 2.43 & 2.37 & 2.31 & 2.27 & 2.22 \\
\hline 101 & 6.89 & 4.82 & 3.98 & 3.51 & 3.20 & 2.99 & 2.82 & 2.69 & 2.59 & 2.50 & 2.43 & 2.37 & 2.31 & 2.26 & 2.22 \\
\hline 102 & 6.89 & 4.82 & 3.98 & 3.51 & 3.20 & 2.98 & 2.82 & 2.69 & 2.59 & 2.50 & 2.43 & 2.36 & 2.31 & 2.26 & 2.22 \\
\hline 103 & 6.89 & 4.82 & 3.98 & 3.51 & 3.20 & 2.98 & 2.82 & 2.69 & 2.58 & 2.50 & 2.42 & 2.36 & 2.31 & 2.26 & 2.22 \\
\hline 104 & 6.89 & 4.82 & 3.98 & 3.51 & 3.20 & 2.98 & 2.82 & 2.69 & 2.58 & 2.50 & 2.42 & 2.36 & 2.31 & 2.26 & 2.22 \\
\hline 105 & 6.88 & 4.81 & 3.97 & 3.50 & 3.20 & 2.98 & 2.81 & 2.69 & 2.58 & 2.49 & 2.42 & 2.36 & 2.30 & 2.26 & 2.21 \\
\hline 106 & 6.88 & 4.81 & 3.97 & 3.50 & 3.19 & 2.98 & 2.81 & 2.68 & 2.58 & 2.49 & 2.42 & 2.36 & 2.30 & 2.25 & 2.21 \\
\hline 107 & 6.88 & 4.81 & 3.97 & 3.50 & 3.19 & 2.98 & 2.81 & 2.68 & 2.58 & 2.49 & 2.42 & 2.36 & 2.30 & 2.25 & 2.21 \\
\hline 108 & 6.88 & 4.81 & 3.97 & 3.50 & 3.19 & 2.97 & 2.81 & 2.68 & 2.58 & 2.49 & 2.42 & 2.35 & 2.30 & 2.25 & 2.21 \\
\hline 109 & 6.87 & 4.81 & 3.97 & 3.50 & 3.19 & 2.97 & 2.81 & 2.68 & 2.57 & 2.49 & 2.41 & 2.35 & 2.30 & 2.25 & 2.21 \\
\hline 110 & 6.87 & 4.80 & 3.96 & 3.49 & 3.19 & 2.97 & 2.81 & 2.68 & 2.57 & 2.49 & 2.41 & 2.35 & 2.30 & 2.25 & 2.21 \\
\hline 111 & 6.87 & 4.80 & 3.96 & 3.49 & 3.19 & 2.97 & 2.80 & 2.68 & 2.57 & 2.48 & 2.41 & 2.35 & 2.29 & 2.25 & 2.20 \\
\hline 112 & 6.87 & 4.80 & 3.96 & 3.49 & 3.19 & 2.97 & 2.80 & 2.67 & 2.57 & 2.48 & 2.41 & 2.35 & 2.29 & 2.25 & 2.20 \\
\hline 113 & 6.86 & 4.80 & 3.96 & 3.49 & 3.18 & 2.97 & 2.80 & 2.67 & 2.57 & 2.48 & 2.41 & 2.35 & 2.29 & 2.24 & 2.20 \\
\hline 114 & 6.86 & 4.80 & 3.96 & 3.49 & 3.18 & 2.96 & 2.80 & 2.67 & 2.57 & 2.48 & 2.41 & 2.34 & 2.29 & 2.24 & 2.20 \\
\hline 115 & 6.86 & 4.79 & 3.96 & 3.49 & 3.18 & 2.96 & 2.80 & 2.67 & 2.57 & 2.48 & 2.41 & 2.34 & 2.29 & 2.24 & 2.20 \\
\hline 116 & 6.86 & 4.79 & 3.96 & 3.49 & 3.18 & 2.96 & 2.80 & 2.67 & 2.56 & 2.48 & 2.40 & 2.34 & 2.29 & 2.24 & 2.20 \\
\hline 117 & 6.86 & 4.79 & 3.95 & 3.48 & 3.18 & 2.96 & 2.80 & 2.67 & 2.56 & 2.48 & 2.40 & 2.34 & 2.29 & 2.24 & 2.20 \\
\hline 118 & 6.85 & 4.79 & 3.95 & 3.48 & 3.18 & 2.96 & 2.79 & 2.67 & 2.56 & 2.47 & 2.40 & 2.34 & 2.28 & 2.24 & 2.19 \\
\hline 119 & 6.85 & 4.79 & 3.95 & 3.48 & 3.17 & 2.96 & 2.79 & 2.66 & 2.56 & 2.47 & 2.40 & 2.34 & 2.28 & 2.24 & 2.19 \\
\hline 120 & 6.85 & 4.79 & 3.95 & 3.48 & 3.17 & 2.96 & 2.79 & 2.66 & 2.56 & 2.47 & 2.40 & 2.34 & 2.28 & 2.23 & 2.19 \\
\hline 121 & 6.85 & 4.78 & 3.95 & 3.48 & 3.17 & 2.95 & 2.79 & 2.66 & 2.56 & 2.47 & 2.40 & 2.34 & 2.28 & 2.23 & 2.19 \\
\hline 122 & 6.85 & 4.78 & 3.95 & 3.48 & 3.17 & 2.95 & 2.79 & 2.66 & 2.56 & 2.47 & 2.40 & 2.33 & 2.28 & 2.23 & 2.19 \\
\hline 123 & 6.85 & 4.78 & 3.94 & 3.48 & 3.17 & 2.95 & 2.79 & 2.66 & 2.55 & 2.47 & 2.40 & 2.33 & 2.28 & 2.23 & 2.19 \\
\hline 124 & 6.84 & 4.78 & 3.94 & 3.47 & 3.17 & 2.95 & 2.79 & 2.66 & 2.55 & 2.47 & 2.39 & 2.33 & 2.28 & 2.23 & 2.19 \\
\hline 125 & 6.84 & 4.78 & 3.94 & 3.47 & 3.17 & 2.95 & 2.79 & 2.66 & 2.55 & 2.47 & 2.39 & 2.33 & 2.28 & 2.23 & 2.19 \\
\hline 126 & 6.84 & 4.78 & 3.94 & 3.47 & 3.17 & 2.95 & 2.78 & 2.66 & 2.55 & 2.46 & 2.39 & 2.33 & 2.27 & 2.23 & 2.18 \\
\hline 127 & 6.84 & 4.78 & 3.94 & 3.47 & 3.16 & 2.95 & 2.78 & 2.65 & 2.55 & 2.46 & 2.39 & 2.33 & 2.27 & 2.23 & 2.18 \\
\hline 128 & 6.84 & 4.77 & 3.94 & 3.47 & 3.16 & 2.95 & 2.78 & 2.65 & 2.55 & 2.46 & 2.39 & 2.33 & 2.27 & 2.22 & 2.18 \\
\hline 129 & 6.84 & 4.77 & 3.94 & 3.47 & 3.16 & 2.94 & 2.78 & 2.65 & 2.55 & 2.46 & 2.39 & 2.33 & 2.27 & 2.22 & 2.18 \\
\hline 130 & 6.83 & 4.77 & 3.94 & 3.47 & 3.16 & 2.94 & 2.78 & 2.65 & 2.55 & 2.46 & 2.39 & 2.32 & 2.27 & 2.22 & 2.18 \\
\hline 131 & 6.83 & 4.77 & 3.93 & 3.47 & 3.16 & 2.94 & 2.78 & 2.65 & 2.55 & 2.46 & 2.39 & 2.32 & 2.27 & 2.22 & 2.18 \\
\hline 132 & 6.83 & 4.77 & 3.93 & 3.46 & 3.16 & 2.94 & 2.78 & 2.65 & 2.54 & 2.46 & 2.38 & 2.32 & 2.27 & 2.22 & 2.18 \\
\hline 133 & 6.83 & 4.77 & 3.93 & 3.46 & 3.16 & 2.94 & 2.78 & 2.65 & 2.54 & 2.46 & 2.38 & 2.32 & 2.27 & 2.22 & 2.18 \\
\hline 134 & 6.83 & 4.77 & 3.93 & 3.46 & 3.16 & 2.94 & 2.78 & 2.65 & 2.54 & 2.46 & 2.38 & 2.32 & 2.27 & 2.22 & 2.18 \\
\hline 135 & 6.83 & 4.77 & 3.93 & 3.46 & 3.16 & 2.94 & 2.77 & 2.65 & 2.54 & 2.45 & 2.38 & 2.32 & 2.26 & 2.22 & 2.17 \\
\hline
\end{tabular}

Diproduksi oleh: Junaidi (http://junaidichaniago.wordpress.com). 2010 
Titik Persentase Distribusi F untuk Probabilita $=0,01$

\begin{tabular}{|c|c|c|c|c|c|c|c|c|c|c|c|c|c|c|c|}
\hline \multirow{2}{*}{$\begin{array}{l}\text { df untuk } \\
\text { penyebut } \\
\text { (N2) }\end{array}$} & \multicolumn{15}{|c|}{ df untuk pembilang (N1) } \\
\hline & 1 & 2 & 3 & 4 & 5 & 6 & 7 & 8 & 9 & 10 & 11 & 12 & 13 & 14 & 15 \\
\hline 136 & 6.82 & 4.76 & 3.93 & 3.46 & 3.15 & 2.94 & 2.77 & 2.64 & 2.54 & 2.45 & 2.38 & 2.32 & 2.26 & 2.22 & 2.17 \\
\hline 137 & 6.82 & 4.76 & 3.93 & 3.46 & 3.15 & 2.94 & 2.77 & 2.64 & 2.54 & 2.45 & 2.38 & 2.32 & 2.26 & 2.21 & 2.17 \\
\hline 138 & 6.82 & 4.76 & 3.93 & 3.46 & 3.15 & 2.94 & 2.77 & 2.64 & 2.54 & 2.45 & 2.38 & 2.32 & 2.26 & 2.21 & 2.17 \\
\hline 139 & 6.82 & 4.76 & 3.93 & 3.46 & 3.15 & 2.93 & 2.77 & 2.64 & 2.54 & 2.45 & 2.38 & 2.32 & 2.26 & 2.21 & 2.17 \\
\hline 140 & 6.82 & 4.76 & 3.92 & 3.46 & 3.15 & 2.93 & 2.77 & 2.64 & 2.54 & 2.45 & 2.38 & 2.31 & 2.26 & 2.21 & 2.17 \\
\hline 141 & 6.82 & 4.76 & 3.92 & 3.46 & 3.15 & 2.93 & 2.77 & 2.64 & 2.54 & 2.45 & 2.38 & 2.31 & 2.26 & 2.21 & 2.17 \\
\hline 142 & 6.82 & 4.76 & 3.92 & 3.45 & 3.15 & 2.93 & 2.77 & 2.64 & 2.53 & 2.45 & 2.38 & 2.31 & 2.26 & 2.21 & 2.17 \\
\hline 143 & 6.82 & 4.76 & 3.92 & 3.45 & 3.15 & 2.93 & 2.77 & 2.64 & 2.53 & 2.45 & 2.37 & 2.31 & 2.26 & 2.21 & 2.17 \\
\hline 144 & 6.81 & 4.76 & 3.92 & 3.45 & 3.15 & 2.93 & 2.77 & 2.64 & 2.53 & 2.45 & 2.37 & 2.31 & 2.26 & 2.21 & 2.17 \\
\hline 145 & 6.81 & 4.75 & 3.92 & 3.45 & 3.15 & 2.93 & 2.76 & 2.64 & 2.53 & 2.45 & 2.37 & 2.31 & 2.26 & 2.21 & 2.16 \\
\hline 146 & 6.81 & 4.75 & 3.92 & 3.45 & 3.15 & 2.93 & 2.76 & 2.64 & 2.53 & 2.44 & 2.37 & 2.31 & 2.25 & 2.21 & 2.16 \\
\hline 147 & 6.81 & 4.75 & 3.92 & 3.45 & 3.14 & 2.93 & 2.76 & 2.63 & 2.53 & 2.44 & 2.37 & 2.31 & 2.25 & 2.21 & 2.16 \\
\hline 148 & 6.81 & 4.75 & 3.92 & 3.45 & 3.14 & 2.93 & 2.76 & 2.63 & 2.53 & 2.44 & 2.37 & 2.31 & 2.25 & 2.20 & 2.16 \\
\hline 149 & 6.81 & 4.75 & 3.92 & 3.45 & 3.14 & 2.93 & 2.76 & 2.63 & 2.53 & 2.44 & 2.37 & 2.31 & 2.25 & 2.20 & 2.16 \\
\hline 150 & 6.81 & 4.75 & 3.91 & 3.45 & 3.14 & 2.92 & 2.76 & 2.63 & 2.53 & 2.44 & 2.37 & 2.31 & 2.25 & 2.20 & 2.16 \\
\hline 151 & 6.81 & 4.75 & 3.91 & 3.45 & 3.14 & 2.92 & 2.76 & 2.63 & 2.53 & 2.44 & 2.37 & 2.30 & 2.25 & 2.20 & 2.16 \\
\hline 152 & 6.80 & 4.75 & 3.91 & 3.45 & 3.14 & 2.92 & 2.76 & 2.63 & 2.53 & 2.44 & 2.37 & 2.30 & 2.25 & 2.20 & 2.16 \\
\hline 153 & 6.80 & 4.75 & 3.91 & 3.44 & 3.14 & 2.92 & 2.76 & 2.63 & 2.53 & 2.44 & 2.37 & 2.30 & 2.25 & 2.20 & 2.16 \\
\hline 154 & 6.80 & 4.75 & 3.91 & 3.44 & 3.14 & 2.92 & 2.76 & 2.63 & 2.52 & 2.44 & 2.36 & 2.30 & 2.25 & 2.20 & 2.16 \\
\hline 155 & 6.80 & 4.74 & 3.91 & 3.44 & 3.14 & 2.92 & 2.76 & 2.63 & 2.52 & 2.44 & 2.36 & 2.30 & 2.25 & 2.20 & 2.16 \\
\hline 156 & 6.80 & 4.74 & 3.91 & 3.44 & 3.14 & 2.92 & 2.76 & 2.63 & 2.52 & 2.44 & 2.36 & 2.30 & 2.25 & 2.20 & 2.16 \\
\hline 157 & 6.80 & 4.74 & 3.91 & 3.44 & 3.14 & 2.92 & 2.76 & 2.63 & 2.52 & 2.44 & 2.36 & 2.30 & 2.25 & 2.20 & 2.15 \\
\hline 158 & 6.80 & 4.74 & 3.91 & 3.44 & 3.14 & 2.92 & 2.75 & 2.63 & 2.52 & 2.43 & 2.36 & 2.30 & 2.24 & 2.20 & 2.15 \\
\hline 159 & 6.80 & 4.74 & 3.91 & 3.44 & 3.13 & 2.92 & 2.75 & 2.62 & 2.52 & 2.43 & 2.36 & 2.30 & 2.24 & 2.20 & 2.15 \\
\hline 160 & 6.80 & 4.74 & 3.91 & 3.44 & 3.13 & 2.92 & 2.75 & 2.62 & 2.52 & 2.43 & 2.36 & 2.30 & 2.24 & 2.20 & 2.15 \\
\hline 161 & 6.79 & 4.74 & 3.91 & 3.44 & 3.13 & 2.92 & 2.75 & 2.62 & 2.52 & 2.43 & 2.36 & 2.30 & 2.24 & 2.19 & 2.15 \\
\hline 162 & 6.79 & 4.74 & 3.90 & 3.44 & 3.13 & 2.92 & 2.75 & 2.62 & 2.52 & 2.43 & 2.36 & 2.30 & 2.24 & 2.19 & 2.15 \\
\hline 163 & 6.79 & 4.74 & 3.90 & 3.44 & 3.13 & 2.91 & 2.75 & 2.62 & 2.52 & 2.43 & 2.36 & 2.30 & 2.24 & 2.19 & 2.15 \\
\hline 164 & 6.79 & 4.74 & 3.90 & 3.44 & 3.13 & 2.91 & 2.75 & 2.62 & 2.52 & 2.43 & 2.36 & 2.29 & 2.24 & 2.19 & 2.15 \\
\hline 165 & 6.79 & 4.74 & 3.90 & 3.43 & 3.13 & 2.91 & 2.75 & 2.62 & 2.52 & 2.43 & 2.36 & 2.29 & 2.24 & 2.19 & 2.15 \\
\hline 166 & 6.79 & 4.74 & 3.90 & 3.43 & 3.13 & 2.91 & 2.75 & 2.62 & 2.52 & 2.43 & 2.36 & 2.29 & 2.24 & 2.19 & 2.15 \\
\hline 167 & 6.79 & 4.73 & 3.90 & 3.43 & 3.13 & 2.91 & 2.75 & 2.62 & 2.52 & 2.43 & 2.36 & 2.29 & 2.24 & 2.19 & 2.15 \\
\hline 168 & 6.79 & 4.73 & 3.90 & 3.43 & 3.13 & 2.91 & 2.75 & 2.62 & 2.51 & 2.43 & 2.35 & 2.29 & 2.24 & 2.19 & 2.15 \\
\hline 169 & 6.79 & 4.73 & 3.90 & 3.43 & 3.13 & 2.91 & 2.75 & 2.62 & 2.51 & 2.43 & 2.35 & 2.29 & 2.24 & 2.19 & 2.15 \\
\hline 170 & 6.79 & 4.73 & 3.90 & 3.43 & 3.13 & 2.91 & 2.75 & 2.62 & 2.51 & 2.43 & 2.35 & 2.29 & 2.24 & 2.19 & 2.15 \\
\hline 171 & 6.79 & 4.73 & 3.90 & 3.43 & 3.13 & 2.91 & 2.75 & 2.62 & 2.51 & 2.43 & 2.35 & 2.29 & 2.24 & 2.19 & 2.15 \\
\hline 172 & 6.78 & 4.73 & 3.90 & 3.43 & 3.13 & 2.91 & 2.74 & 2.62 & 2.51 & 2.43 & 2.35 & 2.29 & 2.24 & 2.19 & 2.14 \\
\hline 173 & 6.78 & 4.73 & 3.90 & 3.43 & 3.12 & 2.91 & 2.74 & 2.62 & 2.51 & 2.42 & 2.35 & 2.29 & 2.23 & 2.19 & 2.14 \\
\hline 174 & 6.78 & 4.73 & 3.90 & 3.43 & 3.12 & 2.91 & 2.74 & 2.61 & 2.51 & 2.42 & 2.35 & 2.29 & 2.23 & 2.19 & 2.14 \\
\hline 175 & 6.78 & 4.73 & 3.90 & 3.43 & 3.12 & 2.91 & 2.74 & 2.61 & 2.51 & 2.42 & 2.35 & 2.29 & 2.23 & 2.19 & 2.14 \\
\hline 176 & 6.78 & 4.73 & 3.89 & 3.43 & 3.12 & 2.91 & 2.74 & 2.61 & 2.51 & 2.42 & 2.35 & 2.29 & 2.23 & 2.18 & 2.14 \\
\hline 177 & 6.78 & 4.73 & 3.89 & 3.43 & 3.12 & 2.91 & 2.74 & 2.61 & 2.51 & 2.42 & 2.35 & 2.29 & 2.23 & 2.18 & 2.14 \\
\hline 178 & 6.78 & 4.73 & 3.89 & 3.43 & 3.12 & 2.90 & 2.74 & 2.61 & 2.51 & 2.42 & 2.35 & 2.29 & 2.23 & 2.18 & 2.14 \\
\hline 179 & 6.78 & 4.73 & 3.89 & 3.43 & 3.12 & 2.90 & 2.74 & 2.61 & 2.51 & 2.42 & 2.35 & 2.29 & 2.23 & 2.18 & 2.14 \\
\hline 180 & 6.78 & 4.73 & 3.89 & 3.43 & 3.12 & 2.90 & 2.74 & 2.61 & 2.51 & 2.42 & 2.35 & 2.28 & 2.23 & 2.18 & 2.14 \\
\hline
\end{tabular}

Diproduksi oleh: Junaidi (http://junaidichaniago.wordpress.com). 2010 


\section{Titik Persentase Distribusi F untuk Probabilita $=0,01$}

\begin{tabular}{|c|c|c|c|c|c|c|c|c|c|c|c|c|c|c|c|}
\hline \multirow{2}{*}{$\begin{array}{l}\text { df untuk } \\
\text { penyebut } \\
\text { (N2) }\end{array}$} & \multicolumn{15}{|c|}{ df untuk pembilang (N1) } \\
\hline & 1 & 2 & 3 & 4 & 5 & 6 & 7 & 8 & 9 & 10 & 11 & 12 & 13 & 14 & 15 \\
\hline 181 & 6.78 & 4.72 & 3.89 & 3.42 & 3.12 & 2.90 & 2.74 & 2.61 & 2.51 & 2.42 & 2.35 & 2.28 & 2.23 & 2.18 & 2.14 \\
\hline 182 & 6.78 & 4.72 & 3.89 & 3.42 & 3.12 & 2.90 & 2.74 & 2.61 & 2.51 & 2.42 & 2.35 & 2.28 & 2.23 & 2.18 & 2.14 \\
\hline 183 & 6.78 & 4.72 & 3.89 & 3.42 & 3.12 & 2.90 & 2.74 & 2.61 & 2.51 & 2.42 & 2.35 & 2.28 & 2.23 & 2.18 & 2.14 \\
\hline 184 & 6.77 & 4.72 & 3.89 & 3.42 & 3.12 & 2.90 & 2.74 & 2.61 & 2.51 & 2.42 & 2.35 & 2.28 & 2.23 & 2.18 & 2.14 \\
\hline 185 & 6.77 & 4.72 & 3.89 & 3.42 & 3.12 & 2.90 & 2.74 & 2.61 & 2.50 & 2.42 & 2.34 & 2.28 & 2.23 & 2.18 & 2.14 \\
\hline 186 & 6.77 & 4.72 & 3.89 & 3.42 & 3.12 & 2.90 & 2.74 & 2.61 & 2.50 & 2.42 & 2.34 & 2.28 & 2.23 & 2.18 & 2.14 \\
\hline 187 & 6.77 & 4.72 & 3.89 & 3.42 & 3.12 & 2.90 & 2.74 & 2.61 & 2.50 & 2.42 & 2.34 & 2.28 & 2.23 & 2.18 & 2.14 \\
\hline 188 & 6.77 & 4.72 & 3.89 & 3.42 & 3.12 & 2.90 & 2.74 & 2.61 & 2.50 & 2.42 & 2.34 & 2.28 & 2.23 & 2.18 & 2.14 \\
\hline 189 & 6.77 & 4.72 & 3.89 & 3.42 & 3.12 & 2.90 & 2.74 & 2.61 & 2.50 & 2.42 & 2.34 & 2.28 & 2.23 & 2.18 & 2.13 \\
\hline 190 & 6.77 & 4.72 & 3.89 & 3.42 & 3.11 & 2.90 & 2.73 & 2.61 & 2.50 & 2.42 & 2.34 & 2.28 & 2.22 & 2.18 & 2.13 \\
\hline 191 & 6.77 & 4.72 & 3.89 & 3.42 & 3.11 & 2.90 & 2.73 & 2.61 & 2.50 & 2.41 & 2.34 & 2.28 & 2.22 & 2.18 & 2.13 \\
\hline 192 & 6.77 & 4.72 & 3.89 & 3.42 & 3.11 & 2.90 & 2.73 & 2.61 & 2.50 & 2.41 & 2.34 & 2.28 & 2.22 & 2.18 & 2.13 \\
\hline 193 & 6.77 & 4.72 & 3.88 & 3.42 & 3.11 & 2.90 & 2.73 & 2.60 & 2.50 & 2.41 & 2.34 & 2.28 & 2.22 & 2.18 & 2.13 \\
\hline 194 & 6.77 & 4.72 & 3.88 & 3.42 & 3.11 & 2.90 & 2.73 & 2.60 & 2.50 & 2.41 & 2.34 & 2.28 & 2.22 & 2.17 & 2.13 \\
\hline 195 & 6.77 & 4.72 & 3.88 & 3.42 & 3.11 & 2.90 & 2.73 & 2.60 & 2.50 & 2.41 & 2.34 & 2.28 & 2.22 & 2.17 & 2.13 \\
\hline 196 & 6.77 & 4.72 & 3.88 & 3,42 & 3.11 & 2.90 & 2.73 & 2.60 & 2.50 & 2.41 & 2.34 & 2.28 & 2.22 & 2.17 & 2.13 \\
\hline 197 & 6.77 & 4.71 & 3.88 & 3.42 & 3.11 & 2.89 & 2.73 & 2.60 & 2.50 & 2.41 & 2.34 & 2.28 & 2.22 & 2.17 & 2.13 \\
\hline 198 & 6.76 & 4.71 & 3.88 & 3.42 & 3.11 & 2.89 & 2.73 & 2.60 & 2.50 & 2.41 & 2.34 & 2.28 & 2.22 & 2.17 & 2.13 \\
\hline 199 & 6.76 & 4.71 & 3.88 & 3.41 & 3.11 & 2.89 & 2.73 & 2.60 & 2.50 & 2.41 & 2.34 & 2.28 & 2.22 & 2.17 & 2.13 \\
\hline 200 & 6.76 & 4.71 & 3.88 & 3.41 & 3.11 & 2.89 & 2.73 & 2.60 & 2.50 & 2.41 & 2.34 & 2.27 & 2.22 & 2.17 & 2.13 \\
\hline 201 & 6.76 & 4.71 & 3.88 & 3.41 & 3.11 & 2.89 & 2.73 & 2.60 & 2.50 & 2.41 & 2.34 & 2.27 & 2.22 & 2.17 & 2.13 \\
\hline 202 & 6.76 & 4.71 & 3.88 & 3.41 & 3.11 & 2.89 & 2.73 & 2.60 & 2.50 & 2.41 & 2.34 & 2.27 & 2.22 & 2.17 & 2.13 \\
\hline 203 & 6.76 & 4.71 & 3.88 & 3.41 & 3.11 & 2.89 & 2.73 & 2.60 & 2.50 & 2.41 & 2.34 & 2.27 & 2.22 & 2.17 & 2.13 \\
\hline 204 & 6.76 & 4.71 & 3.88 & 3.41 & 3.11 & 2.89 & 2.73 & 2.60 & 2.50 & 2.41 & 2.34 & 2.27 & 2.22 & 2.17 & 2.13 \\
\hline 205 & 6.76 & 4.71 & 3.88 & 3.41 & 3.11 & 2.89 & 2.73 & 2.60 & 2.49 & 2.41 & 2.34 & 2.27 & 2.22 & 2.17 & 2.13 \\
\hline 206 & 6.76 & 4.71 & 3.88 & 3.41 & 3.11 & 2.89 & 2.73 & 2.60 & 2.49 & 2.41 & 2.33 & 2.27 & 2.22 & 2.17 & 2.13 \\
\hline 207 & 6.76 & 4.71 & 3.88 & 3.41 & 3.11 & 2.89 & 2.73 & 2.60 & 2.49 & 2.41 & 2.33 & 2.27 & 2.22 & 2.17 & 2.13 \\
\hline 208 & 6.76 & 4.71 & 3.88 & 3.41 & 3.11 & 2.89 & 2.73 & 2.60 & 2.49 & 2.41 & 2.33 & 2.27 & 2.22 & 2.17 & 2.13 \\
\hline 209 & 6.76 & 4.71 & 3.88 & 3.41 & 3.11 & 2.89 & 2.73 & 2.60 & 2.49 & 2.41 & 2.33 & 2.27 & 2.22 & 2.17 & 2.13 \\
\hline 210 & 6.76 & 4.71 & 3.88 & 3.41 & 3.11 & 2.89 & 2.73 & 2.60 & 2.49 & 2.41 & 2.33 & 2.27 & 2.22 & 2.17 & 2.13 \\
\hline 211 & 6.76 & 4.71 & 3.88 & 3.41 & 3.11 & 2.89 & 2.72 & 2.60 & 2.49 & 2.41 & 2.33 & 2.27 & 2.22 & 2.17 & 2.12 \\
\hline 212 & 6.76 & 4.71 & 3.88 & 3.41 & 3.10 & 2.89 & 2.72 & 2.60 & 2.49 & 2.41 & 2.33 & 2.27 & 2.21 & 2.17 & 2.12 \\
\hline 213 & 6.76 & 4.71 & 3.87 & 3.41 & 3.10 & 2.89 & 2.72 & 2.60 & 2.49 & 2.41 & 2.33 & 2.27 & 2.21 & 2.17 & 2.12 \\
\hline 214 & 6.75 & 4.71 & 3.87 & 3.41 & 3.10 & 2.89 & 2.72 & 2.60 & 2.49 & 2.40 & 2.33 & 2.27 & 2.21 & 2.17 & 2.12 \\
\hline 215 & 6.75 & 4.71 & 3.87 & 3.41 & 3.10 & 2.89 & 2.72 & 2.59 & 2.49 & 2.40 & 2.33 & 2.27 & 2.21 & 2.17 & 2.12 \\
\hline 216 & 6.75 & 4.70 & 3.87 & 3.41 & 3.10 & 2.89 & 2.72 & 2.59 & 2.49 & 2.40 & 2.33 & 2.27 & 2.21 & 2.17 & 2.12 \\
\hline 217 & 6.75 & 4.70 & 3.87 & 3.41 & 3.10 & 2.89 & 2.72 & 2.59 & 2.49 & 2.40 & 2.33 & 2.27 & 2.21 & 2.16 & 2.12 \\
\hline 218 & 6.75 & 4.70 & 3.87 & 3.41 & 3.10 & 2.89 & 2.72 & 2.59 & 2.49 & 2.40 & 2.33 & 2.27 & 2.21 & 2.16 & 2.12 \\
\hline 219 & 6.75 & 4.70 & 3.87 & 3.41 & 3.10 & 2.89 & 2.72 & 2.59 & 2.49 & 2.40 & 2.33 & 2.27 & 2.21 & 2.16 & 2.12 \\
\hline 220 & 6.75 & 4.70 & 3.87 & 3.41 & 3.10 & 2.88 & 2.72 & 2.59 & 2.49 & 2.40 & 2.33 & 2.27 & 2.21 & 2.16 & 2.12 \\
\hline 221 & 6.75 & 4.70 & 3.87 & 3.41 & 3.10 & 2.88 & 2.72 & 2.59 & 2.49 & 2.40 & 2.33 & 2.27 & 2.21 & 2.16 & 2.12 \\
\hline 222 & 6.75 & 4.70 & 3.87 & 3.40 & 3.10 & 2.88 & 2.72 & 2.59 & 2.49 & 2.40 & 2.33 & 2.27 & 2.21 & 2.16 & 2.12 \\
\hline 223 & 6.75 & 4.70 & 3.87 & 3.40 & 3.10 & 2.88 & 2.72 & 2.59 & 2.49 & 2.40 & 2.33 & 2.27 & 2.21 & 2.16 & 2.12 \\
\hline 224 & 6.75 & 4.70 & 3.87 & 3.40 & 3.10 & 2.88 & 2.72 & 2.59 & 2.49 & 2.40 & 2.33 & 2.26 & 2.21 & 2.16 & 2.12 \\
\hline 225 & 6.75 & 4.70 & 3.87 & 3.40 & 3.10 & 2.88 & 2.72 & 2.59 & 2.49 & 2.40 & 2.33 & 2.26 & 2.21 & 2.16 & 2.12 \\
\hline
\end{tabular}

Diproduksi oleh: Junaidi (http://junaidichaniago.wordpress.com). 2010 


\title{
Titik Persentase Distribusi F Probabilita $=0.05$
}

\author{
Diproduksi oleh: Junaidi
}

http://junaidichaniago.wordpress.com 
Titik Persentase Distribusi F untuk Probabilita $=0,05$

\begin{tabular}{|c|c|c|c|c|c|c|c|c|c|c|c|c|c|c|c|}
\hline \multirow{2}{*}{$\begin{array}{l}\text { df untuk } \\
\text { penyebut } \\
\text { (N2) }\end{array}$} & \multicolumn{15}{|c|}{ df untuk pembilang (N1) } \\
\hline & 1 & 2 & 3 & 4 & 5 & 6 & 7 & 8 & 9 & 10 & 11 & 12 & 13 & 14 & 15 \\
\hline 1 & 161 & 199 & 216 & 225 & 230 & 234 & 237 & 239 & 241 & 242 & 243 & 244 & 245 & 245 & 246 \\
\hline 2 & 18.51 & 19.00 & 19.16 & 19.25 & 19.30 & 19.33 & 19.35 & 19.37 & 19.38 & 19.40 & 19.40 & 19.41 & 19.42 & 19.42 & 19.43 \\
\hline 3 & 10.13 & 9.55 & 9.28 & 9.12 & 9.01 & 8.94 & 8.89 & 8.85 & 8.81 & 8.79 & 8.76 & 8.74 & 8.73 & 8.71 & 8.70 \\
\hline 4 & 7.71 & 6.94 & 6.59 & 6.39 & 6.26 & 6.16 & 6.09 & 6.04 & 6.00 & 5.96 & 5.94 & 5.91 & 5.89 & 5.87 & 5.86 \\
\hline 5 & 6.61 & 5.79 & 5.41 & 5.19 & 5.05 & 4.95 & 4.88 & 4.82 & 4.77 & 4.74 & 4.70 & 4.68 & 4.66 & 4.64 & 4.62 \\
\hline 6 & 5.99 & 5.14 & 4.76 & 4.53 & 4.39 & 4.28 & 4.21 & 4.15 & 4.10 & 4.06 & 4.03 & 4.00 & 3.98 & 3.96 & 3.94 \\
\hline 7 & 5.59 & 4.74 & 4.35 & 4.12 & 3.97 & 3.87 & 3.79 & 3.73 & 3.68 & 3.64 & 3.60 & 3.57 & 3.55 & 3.53 & 3.51 \\
\hline 8 & 5.32 & 4.46 & 4.07 & 3.84 & 3.69 & 3.58 & 3.50 & 3.44 & 3.39 & 3.35 & 3.31 & 3.28 & 3.26 & 3.24 & 3.22 \\
\hline 9 & 5.12 & 4.26 & 3.86 & 3.63 & 3.48 & 3.37 & 3.29 & 3.23 & 3.18 & 3.14 & 3.10 & 3.07 & 3.05 & 3.03 & 3.01 \\
\hline 10 & 4.96 & 4.10 & 3.71 & 3.48 & 3.33 & 3.22 & 3.14 & 3.07 & 3.02 & 2.98 & 2.94 & 2.91 & 2.89 & 2.86 & 2.85 \\
\hline 11 & 4.84 & 3.98 & 3.59 & 3.36 & 3.20 & 3.09 & 3.01 & 2.95 & 2.90 & 2.85 & 2.82 & 2.79 & 2.76 & .74 & 2.72 \\
\hline 12 & 4.75 & 3.89 & 3.49 & 3.26 & 3.11 & 3.00 & 2.91 & 2.85 & 2.80 & 2.75 & 2.72 & 2.69 & 2.66 & 2.64 & 2.62 \\
\hline 13 & 4.67 & 3.81 & 3.41 & 3.18 & 3.03 & 2.92 & 2.83 & 2.77 & 2.71 & 2.67 & 2.63 & 2.60 & 2.58 & 2.55 & 2.53 \\
\hline 14 & 4.60 & 3.74 & 3.34 & 3.11 & 2.96 & 2.85 & 2.76 & 2.70 & 2.65 & 2.60 & 2.57 & 2.53 & 2.51 & 2.48 & 2.46 \\
\hline 15 & 4.54 & 3.68 & 3.29 & 3.06 & 2.90 & 2.79 & 2.71 & 2.64 & 2.59 & 2.54 & 2.51 & 2.48 & 2.45 & 2.42 & 2.40 \\
\hline 16 & 4.49 & 3.63 & 3.24 & 3.01 & 2.85 & 2.74 & 2.66 & 2.59 & 2.54 & 2.49 & 2.46 & 2.42 & 2.40 & 2.37 & 2.35 \\
\hline 17 & 4.45 & 3.59 & 3.20 & 2.96 & 2.81 & 2.70 & 2.61 & 2.55 & 2.49 & 2.45 & 2.41 & 2.38 & 2.35 & 2.33 & 2.31 \\
\hline 18 & 4.41 & 3.55 & 3.16 & 2.93 & 2.77 & 2.66 & 2.58 & 2.51 & 2.46 & 2.41 & 2.37 & 2.34 & 2.31 & 2.29 & 2.27 \\
\hline 19 & 4.38 & 3.52 & 3.13 & 2.90 & 2.74 & 2.63 & 2.54 & 2.48 & 2.42 & 2.38 & 2.34 & 2.31 & 2.28 & 2.26 & 2.23 \\
\hline 20 & 4.35 & 3.49 & 3.10 & 2.87 & 2.71 & 2.60 & 2.51 & 2.45 & 2.39 & 2.35 & 2.31 & 2.28 & 2.25 & 2.22 & 2.20 \\
\hline 21 & 4.32 & 3.47 & 3.07 & 2.84 & 2.68 & 2.57 & 2.49 & 2.42 & 2.37 & 2.32 & 2.28 & 2.25 & 2.22 & 2.20 & 2.18 \\
\hline 22 & 4.30 & 3.44 & 3.05 & 2.82 & 2.66 & 2.55 & 2.46 & 2.40 & 2.34 & 2.30 & 2.26 & 2.23 & 2.20 & 2.17 & 2.15 \\
\hline 23 & 4.28 & 3.42 & 3.03 & 2.80 & 2.64 & 2.53 & 2.44 & 2.37 & 2.32 & 2.27 & 2.24 & 2.20 & 2.18 & 15 & 2.13 \\
\hline 24 & 4.26 & 3.40 & 3.01 & 2.78 & 2.62 & 2.51 & 2.42 & 2.36 & 2.30 & 2.25 & 2.22 & 2.18 & 2.15 & 13 & 2.11 \\
\hline 25 & 4.24 & 3.39 & 2.99 & 2.76 & 2.60 & 2.49 & 2.40 & 2.34 & 2.28 & 2.24 & 2.20 & 2.16 & 2.14 & 2.11 & 2.09 \\
\hline 26 & 4.23 & 3.37 & 2.98 & 2.74 & 2.59 & 2.47 & 2.39 & 2.32 & 2.27 & 2.22 & 2.18 & 2.15 & 2.12 & 2.09 & 2.07 \\
\hline 27 & 4.21 & 3.35 & 2.96 & 2.73 & 2.57 & 2.46 & 2.37 & 2.31 & 2.25 & 2.20 & 2.17 & 2.13 & 2.10 & 2.08 & 2.06 \\
\hline 28 & 4.20 & 3.34 & 2.95 & 2.71 & 2.56 & 2.45 & 2.36 & 2.29 & 2.24 & 2.19 & 2.15 & 2.12 & 2.09 & 2.06 & 2.04 \\
\hline 29 & 4.18 & 3.33 & 2.93 & 2.70 & 2.55 & 2.43 & 2.35 & 2.28 & 2.22 & 2.18 & 2.14 & 2.10 & 2.08 & 2.05 & 2.03 \\
\hline 30 & 4.17 & 3.32 & 2.92 & 2.69 & 2.53 & 2.42 & 2.33 & 2.27 & 2.21 & 2.16 & 2.13 & 2.09 & 2.06 & 2.04 & 2.01 \\
\hline 31 & 4.16 & 3.30 & 2.91 & 2.68 & 2.52 & 2.41 & 2.32 & 2.25 & 2.20 & 2.15 & 2.11 & 2.08 & 2.05 & 2.03 & 2.00 \\
\hline 32 & 4.15 & 3.29 & 2.90 & 2.67 & 2.51 & 2.40 & 2.31 & 2.24 & 2.19 & 2.14 & 2.10 & 2.07 & 2.04 & 2.01 & 1.99 \\
\hline 33 & 4.14 & 3.28 & 2.89 & 2.66 & 2.50 & 2.39 & 2.30 & 2.23 & 2.18 & 2.13 & 2.09 & 2.06 & 2.03 & 2.00 & 1.98 \\
\hline 34 & 4.13 & 3.28 & 2.88 & 2.65 & 2.49 & 2.38 & 2.29 & 2.23 & 2.17 & 2.12 & 2.08 & 2.05 & 2.02 & 1.99 & 1.97 \\
\hline 35 & 4.12 & 3.27 & 2.87 & 2.64 & 2.49 & 2.37 & 2.29 & 2.22 & 2.16 & 2.11 & 2.07 & 2.04 & 2.01 & 1.99 & 1.96 \\
\hline 36 & 4.11 & 3.26 & 2.87 & 2.63 & 2.48 & 2.36 & 2.28 & 2.21 & 2.15 & 2.11 & 2.07 & 2.03 & 2.00 & 1.98 & 1.95 \\
\hline 37 & 4.11 & 3.25 & 2.86 & 2.63 & 2.47 & 2.36 & 2.27 & 2.20 & 2.14 & 2.10 & 2.06 & 2.02 & 2.00 & 1.97 & 1.95 \\
\hline 38 & 4.10 & 3.24 & 2.85 & 2.62 & 2.46 & 2.35 & 2.26 & 2.19 & 2.14 & 2.09 & 2.05 & 2.02 & 1.99 & 1.96 & 1.94 \\
\hline 39 & 4.09 & 3.24 & 2.85 & 2.61 & 2.46 & 2.34 & 2.26 & 2.19 & 2.13 & 2.08 & 2.04 & 2.01 & 1.98 & 1.95 & 1.93 \\
\hline 40 & 4.08 & 3.23 & 2.84 & 2.61 & 2.45 & 2.34 & 2.25 & 2.18 & 2.12 & 2.08 & 2.04 & 2.00 & 1.97 & 1.95 & 1.92 \\
\hline 41 & 4.08 & 3.23 & 2.83 & 2.60 & 2.44 & 2.33 & 2.24 & 2.17 & 2.12 & 2.07 & 2.03 & 2.00 & 1.97 & 1.94 & 1.92 \\
\hline 42 & 4.07 & 3.22 & 2.83 & 2.59 & 2.44 & 2.32 & 2.24 & 2.17 & 2.11 & 2.06 & 2.03 & 1.99 & 1.96 & 1.94 & 1.91 \\
\hline 43 & 4.07 & 3.21 & 2.82 & 2.59 & 2.43 & 2.32 & 2.23 & 2.16 & 2.11 & 2.06 & 2.02 & 1.99 & 1.96 & 1.93 & 1.91 \\
\hline 44 & 4.06 & 3.21 & 2.82 & 2.58 & 2.43 & 2.31 & 2.23 & 2.16 & 2.10 & 2.05 & 2.01 & 1.98 & 1.95 & 1.92 & 1.90 \\
\hline 45 & 4.06 & 3.20 & 2.81 & 2.58 & 2.42 & 2.31 & 2.22 & 2.15 & 2.10 & 2.05 & 2.01 & 1.97 & 1.94 & 1.92 & 1.89 \\
\hline
\end{tabular}


Titik Persentase Distribusi F untuk Probabilita $=0,05$

\begin{tabular}{|c|c|c|c|c|c|c|c|c|c|c|c|c|c|c|c|}
\hline \multirow{2}{*}{$\begin{array}{l}\text { df untuk } \\
\text { penyebut } \\
\text { (N2) }\end{array}$} & \multicolumn{15}{|c|}{ df untuk pembilang (N1) } \\
\hline & 1 & 2 & 3 & 4 & 5 & 6 & 7 & 8 & 9 & 10 & 11 & 12 & 13 & 14 & 15 \\
\hline 46 & 4.05 & 3.20 & 2.81 & 2.57 & 2.42 & 2.30 & 2.22 & 2.15 & 2.09 & 2.04 & 2.00 & 1.97 & 1.94 & 1.91 & 1.89 \\
\hline 47 & 4.05 & 3.20 & 2.80 & 2.57 & 2.41 & 2.30 & 2.21 & 2.14 & 2.09 & 2.04 & 2.00 & 1.96 & 1.93 & 1.91 & 1.88 \\
\hline 48 & 4.04 & 3.19 & 2.80 & 2.57 & 2.41 & 2.29 & 2.21 & 2.14 & 2.08 & 2.03 & 1.99 & 1.96 & 1.93 & 1.90 & 1.88 \\
\hline 49 & 4.04 & 3.19 & 2.79 & 2.56 & 2.40 & 2.29 & 2.20 & 2.13 & 2.08 & 2.03 & 1.99 & 1.96 & 1.93 & 1.90 & 1.88 \\
\hline 50 & 4.03 & 3.18 & 2.79 & 2.56 & 2.40 & 2.29 & 2.20 & 2.13 & 2.07 & 2.03 & 1.99 & 1.95 & 1.92 & 1.89 & 1.87 \\
\hline 51 & 4.03 & 3.18 & 2.79 & 2.55 & 2.40 & 2.28 & 2.20 & 2.13 & 2.07 & 2.02 & 1.98 & 1.95 & 1.92 & 1.89 & 1.87 \\
\hline 52 & 4.03 & 3.18 & 2.78 & 2.55 & 2.39 & 2.28 & 2.19 & 2.12 & 2.07 & 2.02 & 1.98 & 1.94 & 1.91 & 1.89 & 1.86 \\
\hline 53 & 4.02 & 3.17 & 2.78 & 2.55 & 2.39 & 2.28 & 2.19 & 2.12 & 2.06 & 2.01 & 1.97 & 1.94 & 1.91 & 1.88 & 1.86 \\
\hline 54 & 4.02 & 3.17 & 2.78 & 2.54 & 2.39 & 2.27 & 2.18 & 2.12 & 2.06 & 2.01 & 1.97 & 1.94 & 1.91 & 1.88 & 1.86 \\
\hline 55 & 4.02 & 3.16 & 2.77 & 2.54 & 2.38 & 2.27 & 2.18 & 2.11 & 2.06 & 2.01 & 1.97 & 1.93 & 1.90 & 1.88 & 1.85 \\
\hline 56 & 4.01 & 3.16 & 2.77 & 2.54 & 2.38 & 2.27 & 2.18 & 2.11 & 2.05 & 2.00 & 1.96 & 1.93 & 1.90 & 1.87 & 1.85 \\
\hline 57 & 4.01 & 3.16 & 2.77 & 2.53 & 2.38 & 2.26 & 2.18 & 2.11 & 2.05 & 2.00 & 1.96 & 1.93 & 1.90 & 1.87 & 1.85 \\
\hline 58 & 4.01 & 3.16 & 2.76 & 2.53 & 2.37 & 2.26 & 2.17 & 2.10 & 2.05 & 2.00 & 1.96 & 1.92 & 1.89 & 1.87 & 1.84 \\
\hline 59 & 4.00 & 3.15 & 2.76 & 2.53 & 2.37 & 2.26 & 2.17 & 2.10 & 2.04 & 2.00 & 1.96 & 1.92 & 1.89 & 1.86 & 1.84 \\
\hline 60 & 4.00 & 3.15 & 2.76 & 2.53 & 2.37 & 2.25 & 2.17 & 2.10 & 2.04 & 1.99 & 1.95 & 1.92 & 1.89 & 1.86 & 1.84 \\
\hline 61 & 4.00 & 3.15 & 2.76 & 2.52 & 2.37 & 2.25 & 2.16 & 2.09 & 2.04 & 1.99 & 1.95 & 1.91 & 1.88 & 1.86 & 1.83 \\
\hline 62 & 4.00 & 3.15 & 2.75 & 2.52 & 2.36 & 2.25 & 2.16 & 2.09 & 2.03 & 1.99 & 1.95 & 1.91 & 1.88 & 1.85 & 1.83 \\
\hline 63 & 3.99 & 3.14 & 2.75 & 2.52 & 2.36 & 2.25 & 2.16 & 2.09 & 2.03 & 1.98 & 1.94 & 1.91 & 1.88 & 1.85 & 1.83 \\
\hline 64 & 3.99 & 3.14 & 2.75 & 2.52 & 2.36 & 2.24 & 2.16 & 2.09 & 2.03 & 1.98 & 1.94 & 1.91 & 1.88 & 1.85 & 1.83 \\
\hline 65 & 3.99 & 3.14 & 2.75 & 2.51 & 2.36 & 2.24 & 2.15 & 2.08 & 2.03 & 1.98 & 1.94 & 1.90 & 1.87 & 1.85 & 1.82 \\
\hline 66 & 3.99 & 3.14 & 2.74 & 2.51 & 2.35 & 2.24 & 2.15 & 2.08 & 2.03 & 1.98 & 1.94 & 1.90 & 1.87 & 1.84 & 1.82 \\
\hline 67 & 3.98 & 3.13 & 2.74 & 2.51 & 2.35 & 2.24 & 2.15 & 2.08 & 2.02 & 1.98 & 1.93 & 1.90 & 1.87 & 1.84 & 1.82 \\
\hline 68 & 3.98 & 3.13 & 2.74 & 2.51 & 2.35 & 2.24 & 2.15 & 2.08 & 2.02 & 1.97 & 1.93 & 1.90 & 1.87 & 1.84 & 1.82 \\
\hline 69 & 3.98 & 3.13 & 2.74 & 2.50 & 2.35 & 2.23 & 2.15 & 2.08 & 2.02 & 1.97 & 1.93 & 1.90 & 1.86 & 1.84 & 1.81 \\
\hline 70 & 3.98 & 3.13 & 2.74 & 2.50 & 2.35 & 2.23 & 2.14 & 2.07 & 2.02 & 1.97 & 1.93 & 1.89 & 1.86 & 1.84 & 1.81 \\
\hline 71 & 3.98 & 3.13 & 2.73 & 2.50 & 2.34 & 2.23 & 2.14 & 2.07 & 2.01 & 1.97 & 1.93 & 1.89 & 1.86 & 1.83 & 1.81 \\
\hline 72 & 3.97 & 3.12 & 2.73 & 2.50 & 2.34 & 2.23 & 2.14 & 2.07 & 2.01 & 1.96 & 1.92 & 1.89 & 1.86 & 1.83 & 1.81 \\
\hline 73 & 3.97 & 3.12 & 2.73 & 2.50 & 2.34 & 2.23 & 2.14 & 2.07 & 2.01 & 1.96 & 1.92 & 1.89 & 1.86 & 1.83 & 1.81 \\
\hline 74 & 3.97 & 3.12 & 2.73 & 2.50 & 2.34 & 2.22 & 2.14 & 2.07 & 2.01 & 1.96 & 1.92 & 1.89 & 1.85 & 1.83 & 1.80 \\
\hline 75 & 3.97 & 3.12 & 2.73 & 2.49 & 2.34 & 2.22 & 2.13 & 2.06 & 2.01 & 1.96 & 1.92 & 1.88 & 1.85 & 1.83 & 1.80 \\
\hline 76 & 3.97 & 3.12 & 2.72 & 2.49 & 2.33 & 2.22 & 2.13 & 2.06 & 2.01 & 1.96 & 1.92 & 1.88 & 1.85 & 1.82 & 1.80 \\
\hline 77 & 3.97 & 3.12 & 2.72 & 2.49 & 2.33 & 2.22 & 2.13 & 2.06 & 2.00 & 1.96 & 1.92 & 1.88 & 1.85 & 1.82 & 1.80 \\
\hline 78 & 3.96 & 3.11 & 2.72 & 2.49 & 2.33 & 2.22 & 2.13 & 2.06 & 2.00 & 1.95 & 1.91 & 1.88 & 1.85 & 1.82 & 1.80 \\
\hline 79 & 3.96 & 3.11 & 2.72 & 2.49 & 2.33 & 2.22 & 2.13 & 2.06 & 2.00 & 1.95 & 1.91 & 1.88 & 1.85 & 1.82 & 1.79 \\
\hline 80 & 3.96 & 3.11 & 2.72 & 2.49 & 2.33 & 2.21 & 2.13 & 2.06 & 2.00 & 1.95 & 1.91 & 1.88 & 1.84 & 1.82 & 1.79 \\
\hline 81 & 3.96 & 3.11 & 2.72 & 2.48 & 2.33 & 2.21 & 2.12 & 2.05 & 2.00 & 1.95 & 1.91 & 1.87 & 1.84 & 1.82 & 1.79 \\
\hline 82 & 3.96 & 3.11 & 2.72 & 2.48 & 2.33 & 2.21 & 2.12 & 2.05 & 2.00 & 1.95 & 1.91 & 1.87 & 1.84 & 1.81 & 1.79 \\
\hline 83 & 3.96 & 3.11 & 2.71 & 2.48 & 2.32 & 2.21 & 2.12 & 2.05 & 1.99 & 1.95 & 1.91 & 1.87 & 1.84 & 1.81 & 1.79 \\
\hline 84 & 3.95 & 3.11 & 2.71 & 2.48 & 2.32 & 2.21 & 2.12 & 2.05 & 1.99 & 1.95 & 1.90 & 1.87 & 1.84 & 1.81 & 1.79 \\
\hline 85 & 3.95 & 3.10 & 2.71 & 2.48 & 2.32 & 2.21 & 2.12 & 2.05 & 1.99 & 1.94 & 1.90 & 1.87 & 1.84 & 1.81 & 1.79 \\
\hline 86 & 3.95 & 3.10 & 2.71 & 2.48 & 2.32 & 2.21 & 2.12 & 2.05 & 1.99 & 1.94 & 1.90 & 1.87 & 1.84 & 1.81 & 1.78 \\
\hline 87 & 3.95 & 3.10 & 2.71 & 2.48 & 2.32 & 2.20 & 2.12 & 2.05 & 1.99 & 1.94 & 1.90 & 1.87 & 1.83 & 1.81 & 1.78 \\
\hline 88 & 3.95 & 3.10 & 2.71 & 2.48 & 2.32 & 2.20 & 2.12 & 2.05 & 1.99 & 1.94 & 1.90 & 1.86 & 1.83 & 1.81 & 1.78 \\
\hline 89 & 3.95 & 3.10 & 2.71 & 2.47 & 2.32 & 2.20 & 2.11 & 2.04 & 1.99 & 1.94 & 1.90 & 1.86 & 1.83 & 1.80 & 1.78 \\
\hline 90 & 3.95 & 3.10 & 2.71 & 2.47 & 2.32 & 2.20 & 2.11 & 2.04 & 1.99 & 1.94 & 1.90 & 1.86 & 1.83 & 1.80 & 1.78 \\
\hline
\end{tabular}

Diproduksi oleh: Junaidi (http://junaidichaniago.wordpress.com). 2010 
Titik Persentase Distribusi F untuk Probabilita $=0,05$

\begin{tabular}{|c|c|c|c|c|c|c|c|c|c|c|c|c|c|c|c|}
\hline \multirow{2}{*}{$\begin{array}{l}\text { df untuk } \\
\text { penyebut } \\
\text { (N2) }\end{array}$} & \multicolumn{15}{|c|}{ df untuk pembilang (N1) } \\
\hline & 1 & 2 & 3 & 4 & 5 & 6 & 7 & 8 & 9 & 10 & 11 & 12 & 13 & 14 & 15 \\
\hline 91 & 3.95 & 3.10 & 2.70 & 2.47 & 2.31 & 2.20 & 2.11 & 2.04 & 1.98 & 1.94 & 1.90 & 1.86 & 1.83 & 1.80 & 1.78 \\
\hline 92 & 3.94 & 3.10 & 2.70 & 2.47 & 2.31 & 2.20 & 2.11 & 2.04 & 1.98 & 1.94 & 1.89 & 1.86 & 1.83 & 1.80 & 1.78 \\
\hline 93 & 3.94 & 3.09 & 2.70 & 2.47 & 2.31 & 2.20 & 2.11 & 2.04 & 1.98 & 1.93 & 1.89 & 1.86 & 1.83 & 1.80 & 1.78 \\
\hline 94 & 3.94 & 3.09 & 2.70 & 2.47 & 2.31 & 2.20 & 2.11 & 2.04 & 1.98 & 1.93 & 1.89 & 1.86 & 1.83 & 1.80 & 1.77 \\
\hline 95 & 3.94 & 3.09 & 2.70 & 2.47 & 2.31 & 2.20 & 2.11 & 2.04 & 1.98 & 1.93 & 1.89 & 1.86 & 1.82 & 1.80 & 1.77 \\
\hline 96 & 3.94 & 3.09 & 2.70 & 2.47 & 2.31 & 2.19 & 2.11 & 2.04 & 1.98 & 1.93 & 1.89 & 1.85 & 1.82 & 1.80 & 1.77 \\
\hline 97 & 3.94 & 3.09 & 2.70 & 2.47 & 2.31 & 2.19 & 2.11 & 2.04 & 1.98 & 1.93 & 1.89 & 1.85 & 1.82 & 1.80 & 1.77 \\
\hline 98 & 3.94 & 3.09 & 2.70 & 2.46 & 2.31 & 2.19 & 2.10 & 2.03 & 1.98 & 1.93 & 1.89 & 1.85 & 1.82 & 1.79 & 1.77 \\
\hline 99 & 3.94 & 3.09 & 2.70 & 2.46 & 2.31 & 2.19 & 2.10 & 2.03 & 1.98 & 1.93 & 1.89 & 1.85 & 1.82 & 1.79 & 1.77 \\
\hline 100 & 3.94 & 3.09 & 2.70 & 2.46 & 2.31 & 2.19 & 2.10 & 2.03 & 1.97 & 1.93 & 1.89 & 1.85 & 1.82 & 1.79 & 1.77 \\
\hline 101 & 3.94 & 3.09 & 2.69 & 2.46 & 2.30 & 2.19 & 2.10 & 2.03 & 1.97 & 1.93 & 1.88 & 1.85 & 1.82 & 1.79 & 1.77 \\
\hline 102 & 3.93 & 3.09 & 2.69 & 2.46 & 2.30 & & 2.10 & 2.03 & 1.97 & 1.92 & 1.88 & 1.85 & 82 & 1.79 & 1.77 \\
\hline 103 & 3.93 & 3.08 & 2.69 & 2.46 & 2.30 & 2.19 & 2.10 & 2.03 & 1.97 & 1.92 & 1.88 & 1.85 & 1.82 & 1.79 & 1.76 \\
\hline 104 & 3.93 & 3.08 & 2.69 & 2.46 & 2.30 & 2.19 & 2.10 & 2.03 & 1.97 & 1.92 & 1.88 & 1.85 & 1.82 & 1.79 & 1.76 \\
\hline 105 & 3.93 & 3.08 & 2.69 & 2.46 & 2.30 & 2.19 & 2.10 & 2.03 & 1.97 & 1.92 & 1.88 & 1.85 & 1.81 & 1.79 & 1.76 \\
\hline 106 & 3.93 & 3.08 & 2.69 & 2.46 & 2.30 & 2.19 & 2.10 & 2.03 & 1.97 & 1.92 & 1.88 & 1.84 & 1.81 & 1.79 & 1.76 \\
\hline 107 & 3.93 & 3.08 & 2.69 & 2.46 & 2.30 & 2.18 & 2.10 & 2.03 & 1.97 & 1.92 & 1.88 & 1.84 & 1.81 & 1.79 & 1.76 \\
\hline 108 & 3.93 & 3.08 & 2.69 & 2.46 & 2.30 & 2.18 & 2.10 & 2.03 & 1.97 & 1.92 & 1.88 & 1.84 & 1.81 & 1.78 & 1.76 \\
\hline 109 & 3.93 & 3.08 & 2.69 & 2.45 & 2.30 & 2.18 & 2.09 & 2.02 & 1.97 & 1.92 & 1.88 & 1.84 & 1.81 & 1.78 & 1.76 \\
\hline 110 & 3.93 & 3.08 & 2.69 & 2.45 & 2.30 & 2.18 & 2.09 & 2.02 & 1.97 & 1.92 & 1.88 & 1.84 & 1.81 & 1.78 & 1.76 \\
\hline 111 & 3.93 & 3.08 & 2.69 & 2.45 & 2.30 & 2.18 & 2.09 & 2.02 & 1.97 & 1.92 & 1.88 & 1.84 & 1.81 & 1.78 & 1.76 \\
\hline 112 & 3.93 & 3.08 & 2.69 & 2.45 & 2.30 & 2.18 & 2.09 & 2.02 & 1.96 & 1.92 & 1.88 & 1.84 & 1.81 & 1.78 & 1.76 \\
\hline 113 & 3.93 & 3.08 & 2.68 & 2.45 & 2.29 & 2.18 & 2.09 & 2.02 & 1.96 & 1.92 & 1.87 & 1.84 & 1.81 & 1.78 & 1.76 \\
\hline 114 & 3.92 & 3.08 & 2.68 & 2.45 & 2.29 & 2.18 & 2.09 & 2.02 & 1.96 & 1.91 & 1.87 & 1.84 & 1.81 & 1.78 & 1.75 \\
\hline 115 & 3.92 & 3.08 & 2.68 & 2.45 & 2.29 & 2.18 & 2.09 & 2.02 & 1.96 & 1.91 & 1.87 & 1.84 & 1.81 & 1.78 & 1.75 \\
\hline 116 & 3.92 & 3.07 & 2.68 & 2.45 & 2.29 & 2.18 & 2.09 & 2.02 & 1.96 & 1.91 & 1.87 & 1.84 & 1.81 & 1.78 & 1.75 \\
\hline 117 & 3.92 & 3.07 & 2.68 & 2.45 & 2.29 & 2.18 & 2.09 & 2.02 & 1.96 & 1.91 & 1.87 & 1.84 & 1.80 & 1.78 & 1.75 \\
\hline 118 & 3.92 & 3.07 & 2.68 & 2.45 & 2.29 & 2.18 & 2.09 & 2.02 & 1.96 & 1.91 & 1.87 & 1.84 & 1.80 & 1.78 & 1.75 \\
\hline 119 & 3.92 & 3.07 & 2.68 & 2.45 & 2.29 & 2.18 & 2.09 & 2.02 & 1.96 & 1.91 & 1.87 & 1.83 & 1.80 & 1.78 & 1.75 \\
\hline 120 & 3.92 & 3.07 & 2.68 & 2.45 & 2.29 & 2.18 & 2.09 & 2.02 & 1.96 & 1.91 & 1.87 & 1.83 & 1.80 & 1.78 & 1.75 \\
\hline 121 & 3.92 & 3.07 & 2.68 & 2.45 & 2.29 & 2.17 & 2.09 & 2.02 & 1.96 & 1.91 & 1.87 & 1.83 & 1.80 & 1.77 & 1.75 \\
\hline 122 & 3.92 & 3.07 & 2.68 & 2.45 & 2.29 & 2.17 & 2.09 & 2.02 & 1.96 & 1.91 & 1.87 & 1.83 & 1.80 & 1.77 & 1.75 \\
\hline 123 & 3.92 & 3.07 & 2.68 & 2.45 & 2.29 & 2.17 & 2.08 & 2.01 & 1.96 & 1.91 & 1.87 & 1.83 & 1.80 & 1.77 & 1.75 \\
\hline 124 & 3.92 & 3.07 & 2.68 & 2.44 & 2.29 & 2.17 & 2.08 & 2.01 & 1.96 & 1.91 & 1.87 & 1.83 & 1.80 & 1.77 & 1.75 \\
\hline 125 & 3.92 & 3.07 & 2.68 & 2.44 & 2.29 & 2.17 & 2.08 & 2.01 & 1.96 & 1.91 & 1.87 & 1.83 & 1.80 & 1.77 & 1.75 \\
\hline 126 & 3.92 & 3.07 & 2.68 & 2.44 & 2.29 & 2.17 & 2.08 & 2.01 & 1.95 & 1.91 & 1.87 & 1.83 & 1.80 & 1.77 & 1.75 \\
\hline 127 & 3.92 & 3.07 & 2.68 & 2.44 & 2.29 & 2.17 & 2.08 & 2.01 & 1.95 & 1.91 & 1.86 & 1.83 & 1.80 & 1.77 & 1.75 \\
\hline 128 & 3.92 & 3.07 & 2.68 & 2.44 & 2.29 & 2.17 & 2.08 & 2.01 & 1.95 & 1.91 & 1.86 & 1.83 & 1.80 & 1.77 & 1.75 \\
\hline 129 & 3.91 & 3.07 & 2.67 & 2.44 & 2.28 & 2.17 & 2.08 & 2.01 & 1.95 & 1.90 & 1.86 & 1.83 & 1.80 & 1.77 & 1.74 \\
\hline 130 & 3.91 & 3.07 & 2.67 & 2.44 & 2.28 & 2.17 & 2.08 & 2.01 & 1.95 & 1.90 & 1.86 & 1.83 & 1.80 & 1.77 & 1.74 \\
\hline 131 & 3.91 & 3.07 & 2.67 & 2.44 & 2.28 & 2.17 & 2.08 & 2.01 & 1.95 & 1.90 & 1.86 & 1.83 & 1.80 & 1.77 & 1.74 \\
\hline 132 & 3.91 & 3.06 & 2.67 & 2.44 & 2.28 & 2.17 & 2.08 & 2.01 & 1.95 & 1.90 & 1.86 & 1.83 & 1.79 & 1.77 & 1.74 \\
\hline 133 & 3.91 & 3.06 & 2.67 & 2.44 & 2.28 & 2.17 & 2.08 & 2.01 & 1.95 & 1.90 & 1.86 & 1.83 & 1.79 & 1.77 & 1.74 \\
\hline 134 & 3.91 & 3.06 & 2.67 & 2.44 & 2.28 & 2.17 & 2.08 & 2.01 & 1.95 & 1.90 & 1.86 & 1.83 & 1.79 & 1.77 & 1.74 \\
\hline 135 & 3.91 & 3.06 & 2.67 & 2.44 & 2.28 & 2.17 & 2.08 & 2.01 & 1.95 & 1.90 & 1.86 & 1.82 & 1.79 & 1.77 & 1.74 \\
\hline
\end{tabular}

Diproduksi oleh: Junaidi (http://junaidichaniago.wordpress.com). 2010 
Titik Persentase Distribusi F untuk Probabilita $=0,05$

\begin{tabular}{|c|c|c|c|c|c|c|c|c|c|c|c|c|c|c|c|}
\hline \multirow{2}{*}{$\begin{array}{l}\text { df untuk } \\
\text { penyebut } \\
\text { (N2) }\end{array}$} & \multicolumn{15}{|c|}{ df untuk pembilang (N1) } \\
\hline & 1 & 2 & 3 & 4 & 5 & 6 & 7 & 8 & 9 & 10 & 11 & 12 & 13 & 14 & 15 \\
\hline 136 & 3.91 & 3.06 & 2.67 & 2.44 & 2.28 & 2.17 & 2.08 & 2.01 & 1.95 & 1.90 & 1.86 & 1.82 & 1.79 & 1.77 & 1.74 \\
\hline 137 & 3.91 & 3.06 & 2.67 & 2.44 & 2.28 & 2.17 & 2.08 & 2.01 & 1.95 & 1.90 & 1.86 & 1.82 & 1.79 & 1.76 & 1.74 \\
\hline 138 & 3.91 & 3.06 & 2.67 & 2.44 & 2.28 & 2.16 & 2.08 & 2.01 & 1.95 & 1.90 & 1.86 & 1.82 & 1.79 & 1.76 & 1.74 \\
\hline 139 & 3.91 & 3.06 & 2.67 & 2.44 & 2.28 & 2.16 & 2.08 & 2.01 & 1.95 & 1.90 & 1.86 & 1.82 & 1.79 & 1.76 & 1.74 \\
\hline 140 & 3.91 & 3.06 & 2.67 & 2.44 & 2.28 & 2.16 & 2.08 & 2.01 & 1.95 & 1.90 & 1.86 & 1.82 & 1.79 & 1.76 & 1.74 \\
\hline 141 & 3.91 & 3.06 & 2.67 & 2.44 & 2.28 & 2.16 & 2.08 & 2.00 & 1.95 & 1.90 & 1.86 & 1.82 & 1.79 & 1.76 & 1.74 \\
\hline 142 & 3.91 & 3.06 & 2.67 & 2.44 & 2.28 & 2.16 & 2.07 & 2.00 & 1.95 & 1.90 & 1.86 & 1.82 & 1.79 & 1.76 & 1.74 \\
\hline 143 & 3.91 & 3.06 & 2.67 & 2.43 & 2.28 & 2.16 & 2.07 & 2.00 & 1.95 & 1.90 & 1.86 & 1.82 & 1.79 & 1.76 & 1.74 \\
\hline 144 & 3.91 & 3.06 & 2.67 & 2.43 & 2.28 & 2.16 & 2.07 & 2.00 & 1.95 & 1.90 & 1.86 & 1.82 & 1.79 & 1.76 & 1.74 \\
\hline 145 & 3.91 & 3.06 & 2.67 & 2.43 & 2.28 & 2.16 & 2.07 & 2.00 & 1.94 & 1.90 & 1.86 & 1.82 & 1.79 & 1.76 & 1.74 \\
\hline 146 & 3.91 & 3.06 & 2.67 & 2.43 & 2.28 & 2.16 & 2.07 & 2.00 & 1.94 & 1.90 & 1.85 & 1.82 & 1.79 & 1.76 & 1.74 \\
\hline 147 & 3.91 & 3.06 & 2.67 & 2.43 & 2.28 & 2.16 & 2.07 & 2.00 & 1.94 & 1.90 & 1.85 & 1.82 & 1.79 & 1.76 & 1.73 \\
\hline 148 & 3.91 & 3.06 & 2.67 & 2.43 & 2.28 & 2.16 & 2.07 & 2.00 & 1.94 & 1.90 & 1.85 & 1.82 & 1.79 & 1.76 & 1.73 \\
\hline 149 & 3.90 & 3.06 & 2.67 & 2.43 & 2.27 & 2.16 & 2.07 & 2.00 & 1.94 & 1.89 & 1.85 & 1.82 & 1.79 & 1.76 & 1.73 \\
\hline 150 & 3.90 & 3.06 & 2.66 & 2.43 & 2.27 & 2.16 & 2.07 & 2.00 & 1.94 & 1.89 & 1.85 & 1.82 & 1.79 & 1.76 & 1.73 \\
\hline 151 & 3.90 & 3.06 & 2.66 & 2.43 & 2.27 & 2.16 & 2.07 & 2.00 & 1.94 & 1.89 & 1.85 & 1.82 & 1.79 & 1.76 & 1.73 \\
\hline 152 & 3.90 & 3.06 & 2.66 & 2.43 & 2.27 & 2.16 & 2.07 & 2.00 & 1.94 & 1.89 & 1.85 & 1.82 & 1.79 & 1.76 & 1.73 \\
\hline 153 & 3.90 & 3.06 & 2.66 & 2.43 & 2.27 & 2.16 & 2.07 & 2.00 & 1.94 & 1.89 & 1.85 & 1.82 & 1.78 & 1.76 & 1.73 \\
\hline 154 & 3.90 & 3.05 & 2.66 & 2.43 & 2.27 & 2.16 & 2.07 & 2.00 & 1.94 & 1.89 & 1.85 & 1.82 & 1.78 & 1.76 & 1.73 \\
\hline 155 & 3.90 & 3.05 & 2.66 & 2.43 & 2.27 & 2.16 & 2.07 & 2.00 & 1.94 & 1.89 & 1.85 & 1.82 & 1.78 & 1.76 & 1.73 \\
\hline 156 & 3.90 & 3.05 & 2.66 & 2.43 & 2.27 & 2.16 & 2.07 & 2.00 & 1.94 & 1.89 & 1.85 & 1.81 & 1.78 & 1.76 & 1.73 \\
\hline 157 & 3.90 & 3.05 & 2.66 & 2.43 & 2.27 & 2.16 & 2.07 & 2.00 & 1.94 & 1.89 & 1.85 & 1.81 & 1.78 & 1.76 & 1.73 \\
\hline 158 & 3.90 & 3.05 & 2.66 & 2.43 & 2.27 & 2.16 & 2.07 & 2.00 & 1.94 & 1.89 & 1.85 & 1.81 & 1.78 & 1.75 & 1.73 \\
\hline 159 & 3.90 & 3.05 & 2.66 & 2.43 & 2.27 & 2.16 & 2.07 & 2.00 & 1.94 & 1.89 & 1.85 & 1.81 & 1.78 & 1.75 & 1.73 \\
\hline 160 & 3.90 & 3.05 & 2.66 & 2.43 & 2.27 & 2.16 & 2.07 & 2.00 & 1.94 & 1.89 & 1.85 & 1.81 & 1.78 & 1.75 & 1.73 \\
\hline 161 & 3.90 & 3.05 & 2.66 & 2.43 & 2.27 & 2.16 & 2.07 & 2.00 & 1.94 & 1.89 & 1.85 & 1.81 & 1.78 & 1.75 & 1.73 \\
\hline 162 & 3.90 & 3.05 & 2.66 & 2.43 & 2.27 & 2.15 & 2.07 & 2.00 & 1.94 & 1.89 & 1.85 & 1.81 & 1.78 & 1.75 & 1.73 \\
\hline 163 & 3.90 & 3.05 & 2.66 & 2.43 & 2.27 & 2.15 & 2.07 & 2.00 & 1.94 & 1.89 & 1.85 & 1.81 & 1.78 & 1.75 & 1.73 \\
\hline 164 & 3.90 & 3.05 & 2.66 & 2.43 & 2.27 & 2.15 & 2.07 & 2.00 & 1.94 & 1.89 & 1.85 & 1.81 & 1.78 & 1.75 & 1.73 \\
\hline 165 & 3.90 & 3.05 & 2.66 & 2.43 & 2.27 & 2.15 & 2.07 & 1.99 & 1.94 & 1.89 & 1.85 & 1.81 & 1.78 & 1.75 & 1.73 \\
\hline 166 & 3.90 & 3.05 & 2.66 & 2.43 & 2.27 & 2.15 & 2.07 & 1.99 & 1.94 & 1.89 & 1.85 & 1.81 & 1.78 & 1.75 & 1.73 \\
\hline 167 & 3.90 & 3.05 & 2.66 & 2.43 & 2.27 & 2.15 & 2.06 & 1.99 & 1.94 & 1.89 & 1.85 & 1.81 & 1.78 & 1.75 & 1.73 \\
\hline 168 & 3.90 & 3.05 & 2.66 & 2.43 & 2.27 & 2.15 & 2.06 & 1.99 & 1.94 & 1.89 & 1.85 & 1.81 & 1.78 & 1.75 & 1.73 \\
\hline 169 & 3.90 & 3.05 & 2.66 & 2.43 & 2.27 & 2.15 & 2.06 & 1.99 & 1.94 & 1.89 & 1.85 & 1.81 & 1.78 & 1.75 & 1.73 \\
\hline 170 & 3.90 & 3.05 & 2.66 & 2.42 & 2.27 & 2.15 & 2.06 & 1.99 & 1.94 & 1.89 & 1.85 & 1.81 & 1.78 & 1.75 & 1.73 \\
\hline 171 & 3.90 & 3.05 & 2.66 & 2.42 & 2.27 & 2.15 & 2.06 & 1.99 & 1.93 & 1.89 & 1.85 & 1.81 & 1.78 & 1.75 & 1.73 \\
\hline 172 & 3.90 & 3.05 & 2.66 & 2.42 & 2.27 & 2.15 & 2.06 & 1.99 & 1.93 & 1.89 & 1.84 & 1.81 & 1.78 & 1.75 & 1.72 \\
\hline 173 & 3.90 & 3.05 & 2.66 & 2.42 & 2.27 & 2.15 & 2.06 & 1.99 & 1.93 & 1.89 & 1.84 & 1.81 & 1.78 & 1.75 & 1.72 \\
\hline 174 & 3.90 & 3.05 & 2.66 & 2.42 & 2.27 & 2.15 & 2.06 & 1.99 & 1.93 & 1.89 & 1.84 & 1.81 & 1.78 & 1.75 & 1.72 \\
\hline 175 & 3.90 & 3.05 & 2.66 & 2.42 & 2.27 & 2.15 & 2.06 & 1.99 & 1.93 & 1.89 & 1.84 & 1.81 & 1.78 & 1.75 & 1.72 \\
\hline 176 & 3.89 & 3.05 & 2.66 & 2.42 & 2.27 & 2.15 & 2.06 & 1.99 & 1.93 & 1.88 & 1.84 & 1.81 & 1.78 & 1.75 & 1.72 \\
\hline 177 & 3.89 & 3.05 & 2.66 & 2.42 & 2.27 & 2.15 & 2.06 & 1.99 & 1.93 & 1.88 & 1.84 & 1.81 & 1.78 & 1.75 & 1.72 \\
\hline 178 & 3.89 & 3.05 & 2.66 & 2.42 & 2.26 & 2.15 & 2.06 & 1.99 & 1.93 & 1.88 & 1.84 & 1.81 & 1.78 & 1.75 & 1.72 \\
\hline 179 & 3.89 & 3.05 & 2.66 & 2.42 & 2.26 & 2.15 & 2.06 & 1.99 & 1.93 & 1.88 & 1.84 & 1.81 & 1.78 & 1.75 & 1.72 \\
\hline 180 & 3.89 & 3.05 & 2.65 & 2.42 & 2.26 & 2.15 & 2.06 & 1.99 & 1.93 & 1.88 & 1.84 & 1.81 & 1.77 & 1.75 & 1.72 \\
\hline
\end{tabular}

Diproduksi oleh: Junaidi (http://junaidichaniago.wordpress.com). 2010 
Titik Persentase Distribusi F untuk Probabilita $=0,05$

\begin{tabular}{|c|c|c|c|c|c|c|c|c|c|c|c|c|c|c|c|}
\hline \multirow{2}{*}{$\begin{array}{l}\text { df untuk } \\
\text { penyebut } \\
\text { (N2) }\end{array}$} & \multicolumn{15}{|c|}{ df untuk pembilang (N1) } \\
\hline & 1 & 2 & 3 & 4 & 5 & 6 & 7 & 8 & 9 & 10 & 11 & 12 & 13 & 14 & 15 \\
\hline 181 & 3.89 & 3.05 & 2.65 & 2.42 & 2.26 & 2.15 & 2.06 & 1.99 & 1.93 & 1.88 & 1.84 & 1.81 & 1.77 & 1.75 & 1.72 \\
\hline 182 & 3.89 & 3.05 & 2.65 & 2.42 & 2.26 & 2.15 & 2.06 & 1.99 & 1.93 & 1.88 & 1.84 & 1.81 & 1.77 & 1.75 & 1.72 \\
\hline 183 & 3.89 & 3.05 & 2.65 & 2.42 & 2.26 & 2.15 & 2.06 & 1.99 & 1.93 & 1.88 & 1.84 & 1.81 & 1.77 & 1.75 & 1.72 \\
\hline 184 & 3.89 & 3.05 & 2.65 & 2.42 & 2.26 & 2.15 & 2.06 & 1.99 & 1.93 & 1.88 & 1.84 & 1.81 & 1.77 & 1.75 & 1.72 \\
\hline 185 & 3.89 & 3.04 & 2.65 & 2.42 & 2.26 & 2.15 & 2.06 & 1.99 & 1.93 & 1.88 & 1.84 & 1.80 & 1.77 & 1.75 & 1.72 \\
\hline 186 & 3.89 & 3.04 & 2.65 & 2.42 & 2.26 & 2.15 & 2.06 & 1.99 & 1.93 & 1.88 & 1.84 & 1.80 & 1.77 & 1.75 & 1.72 \\
\hline 187 & 3.89 & 3.04 & 2.65 & 2.42 & 2.26 & 2.15 & 2.06 & 1.99 & 1.93 & 1.88 & 1.84 & 1.80 & 1.77 & 1.74 & 1.72 \\
\hline 188 & 3.89 & 3.04 & 2.65 & 2.42 & 2.26 & 2.15 & 2.06 & 1.99 & 1.93 & 1.88 & 1.84 & 1.80 & 1.77 & 1.74 & 1.72 \\
\hline 189 & 3.89 & 3.04 & 2.65 & 2.42 & 2.26 & 2.15 & 2.06 & 1.99 & 1.93 & 1.88 & 1.84 & 1.80 & 1.77 & 1.74 & 1.72 \\
\hline 190 & 3.89 & 3.04 & 2.65 & 2.42 & 2.26 & 2.15 & 2.06 & 1.99 & 1.93 & 1.88 & 1.84 & 1.80 & 1.77 & 1.74 & 1.72 \\
\hline 191 & 3.89 & 3.04 & 2.65 & 2.42 & 2.26 & 2.15 & 2.06 & 1.99 & 1.93 & 1.88 & 1.84 & 1.80 & 1.77 & 1.74 & 1.72 \\
\hline 192 & 3.89 & 3.04 & 2.65 & 2.42 & 2.26 & 2.15 & 2.06 & 1.99 & 1.93 & 1.88 & 1.84 & 1.80 & 1.77 & 1.74 & 1.72 \\
\hline 193 & 3.89 & 3.04 & 2.65 & 2.42 & 2.26 & 2.15 & 2.06 & 1.99 & 1.93 & 1.88 & 1.84 & 1.80 & 1.77 & 1.74 & 1.72 \\
\hline 194 & 3.89 & 3.04 & 2.65 & 2.42 & 2.26 & 2.15 & 2.06 & 1.99 & 1.93 & 1.88 & 1.84 & 1.80 & 1.77 & 1.74 & 1.72 \\
\hline 195 & 3.89 & 3.04 & 2.65 & 2.42 & 2.26 & 2.15 & 2.06 & 1.99 & 1.93 & 1.88 & 1.84 & 1.80 & 1.77 & 74 & 1.72 \\
\hline 196 & 3.89 & 3.04 & 2.65 & 2.42 & 2.26 & 2.15 & 2.06 & 1.99 & 1.93 & 1.88 & 1.84 & 1.80 & 1.77 & 1.74 & 1.72 \\
\hline 197 & 3.89 & 3.04 & 2.65 & 2.42 & 2.26 & 2.14 & 2.06 & 1.99 & 1.93 & 1.88 & 1.84 & 1.80 & 1.77 & 1.74 & 1.72 \\
\hline 198 & 3.89 & 3.04 & 2.65 & & 2.26 & & & 1.99 & & 1.88 & 1.84 & 1.80 & & & 1.72 \\
\hline 199 & 3.89 & 3.04 & 2.65 & 2.42 & 2.26 & 2.14 & 2.06 & 1.99 & 1.93 & 1.88 & 1.84 & 1.80 & 1.77 & 1.74 & 1.72 \\
\hline 200 & 3.89 & 3.04 & 2.65 & 2.42 & 2.26 & 2.14 & 2.06 & 1.98 & 1.93 & 1.88 & 1.84 & 1.80 & 1.77 & 1.74 & 1.72 \\
\hline 201 & 3.89 & 3.04 & 2.65 & 2.42 & 2.26 & 2.14 & 2.06 & 1.98 & 1.93 & 1.88 & 1.84 & 1.80 & 1.77 & 74 & 1.72 \\
\hline 202 & 3.89 & 3.04 & 2.65 & 2.42 & 2.26 & 2.14 & 2.06 & 1.98 & 1.93 & 1.88 & 1.84 & 1.80 & 1.77 & 1.74 & 1.72 \\
\hline 203 & 3.89 & 3.04 & 2.65 & 2.42 & 2.26 & 2.14 & 2.05 & 1.98 & 1.93 & 1.88 & 1.84 & 1.80 & 1.77 & 1.74 & 1.72 \\
\hline 204 & 3.89 & 3.04 & 2.65 & 2.42 & 2.26 & 2.14 & 2.05 & 1.98 & 1.93 & 1.88 & 1.84 & 1.80 & 1.77 & 1.74 & 1.72 \\
\hline 205 & 3.89 & 3.04 & 2.65 & 2.42 & 2.26 & 2.14 & 2.05 & 1.98 & 1.93 & 1.88 & 1.84 & 1.80 & 1.77 & 1.74 & 1.72 \\
\hline 206 & 3.89 & 3.04 & 2.65 & 2.42 & 2.26 & 2.14 & 2.05 & 1.98 & 1.93 & 1.88 & 1.84 & 1.80 & 1.77 & 1.74 & 1.72 \\
\hline 207 & 3.89 & 3.04 & 2.65 & 2.42 & 2.26 & 2.14 & 2.05 & 1.98 & 1.93 & 1.88 & 1.84 & 1.80 & 1.77 & 1.74 & 1.71 \\
\hline 208 & 3.89 & 3.04 & 2.65 & 2.42 & 2.26 & 2.14 & 2.05 & 1.98 & 1.93 & 1.88 & 1.83 & 1.80 & 1.77 & 1.74 & 1.71 \\
\hline 209 & 3.89 & 3.04 & 2.65 & 2.41 & 2.26 & 2.14 & 2.05 & 1.98 & 1.92 & 1.88 & 1.83 & 1.80 & 1.77 & 1.74 & 1.71 \\
\hline 210 & 3.89 & 3.04 & 2.65 & 2.41 & 2.26 & 2.14 & 2.05 & 1.98 & 1.92 & 1.88 & 1.83 & 1.80 & 1.77 & 1.74 & 1.71 \\
\hline 211 & 3.89 & 3.04 & 2.65 & 2.41 & 2.26 & 2.14 & 2.05 & 1.98 & 1.92 & 1.88 & 1.83 & 1.80 & 1.77 & 1.74 & 1.71 \\
\hline 212 & 3.89 & 3.04 & 2.65 & 2.41 & 2.26 & 2.14 & 2.05 & 1.98 & 1.92 & 1.88 & 1.83 & 1.80 & 1.77 & 1.74 & 1.71 \\
\hline 213 & 3.89 & 3.04 & 2.65 & 2.41 & 2.26 & 2.14 & 2.05 & 1.98 & 1.92 & 1.88 & 1.83 & 1.80 & 1.77 & 1.74 & 1.71 \\
\hline 214 & 3.89 & 3.04 & 2.65 & 2.41 & 2.26 & 2.14 & 2.05 & 1.98 & 1.92 & 1.88 & 1.83 & 1.80 & 1.77 & 1.74 & 1.71 \\
\hline 215 & 3.89 & 3.04 & 2.65 & 2.41 & 2.26 & 2.14 & 2.05 & 1.98 & 1.92 & 1.87 & 1.83 & 1.80 & 1.77 & 1.74 & 1.71 \\
\hline 216 & 3.88 & 3.04 & 2.65 & 2.41 & 2.26 & 2.14 & 2.05 & 1.98 & 1.92 & 1.87 & 1.83 & 1.80 & 1.77 & 1.74 & 1.71 \\
\hline 217 & 3.88 & 3.04 & 2.65 & 2.41 & 2.26 & 2.14 & 2.05 & 1.98 & 1.92 & 1.87 & 1.83 & 1.80 & 1.77 & 1.74 & 1.71 \\
\hline 218 & 3.88 & 3.04 & 2.65 & 2.41 & 2.26 & 2.14 & 2.05 & 1.98 & 1.92 & 1.87 & 1.83 & 1.80 & 1.77 & 1.74 & 1.71 \\
\hline 219 & 3.88 & 3.04 & 2.65 & 2.41 & 2.26 & 2.14 & 2.05 & 1.98 & 1.92 & 1.87 & 1.83 & 1.80 & 1.77 & 1.74 & 1.71 \\
\hline 220 & 3.88 & 3.04 & 2.65 & 2.41 & 2.26 & 2.14 & 2.05 & 1.98 & 1.92 & 1.87 & 1.83 & 1.80 & 1.76 & 1.74 & 1.71 \\
\hline 221 & 3.88 & 3.04 & 2.65 & 2.41 & 2.25 & 2.14 & 2.05 & 1.98 & 1.92 & 1.87 & 1.83 & 1.80 & 1.76 & 1.74 & 1.71 \\
\hline 222 & 3.88 & 3.04 & 2.65 & 2.41 & 2.25 & 2.14 & 2.05 & 1.98 & 1.92 & 1.87 & 1.83 & 1.80 & 1.76 & 1.74 & 1.71 \\
\hline 223 & 3.88 & 3.04 & 2.65 & 2.41 & 2.25 & 2.14 & 2.05 & 1.98 & 1.92 & 1.87 & 1.83 & 1.80 & 1.76 & 1.74 & 1.71 \\
\hline 224 & 3.88 & 3.04 & 2.64 & 2.41 & 2.25 & 2.14 & 2.05 & 1.98 & 1.92 & 1.87 & 1.83 & 1.80 & 1.76 & 1.74 & 1.71 \\
\hline 225 & 3.88 & 3.04 & 2.64 & 2.41 & 2.25 & 2.14 & 2.05 & 1.98 & 1.92 & 1.87 & 1.83 & 1.80 & 1.76 & 1.74 & 1.71 \\
\hline
\end{tabular}




\section{Lampiran 3. Tabel Durbin Watson (Evans, 2016)}

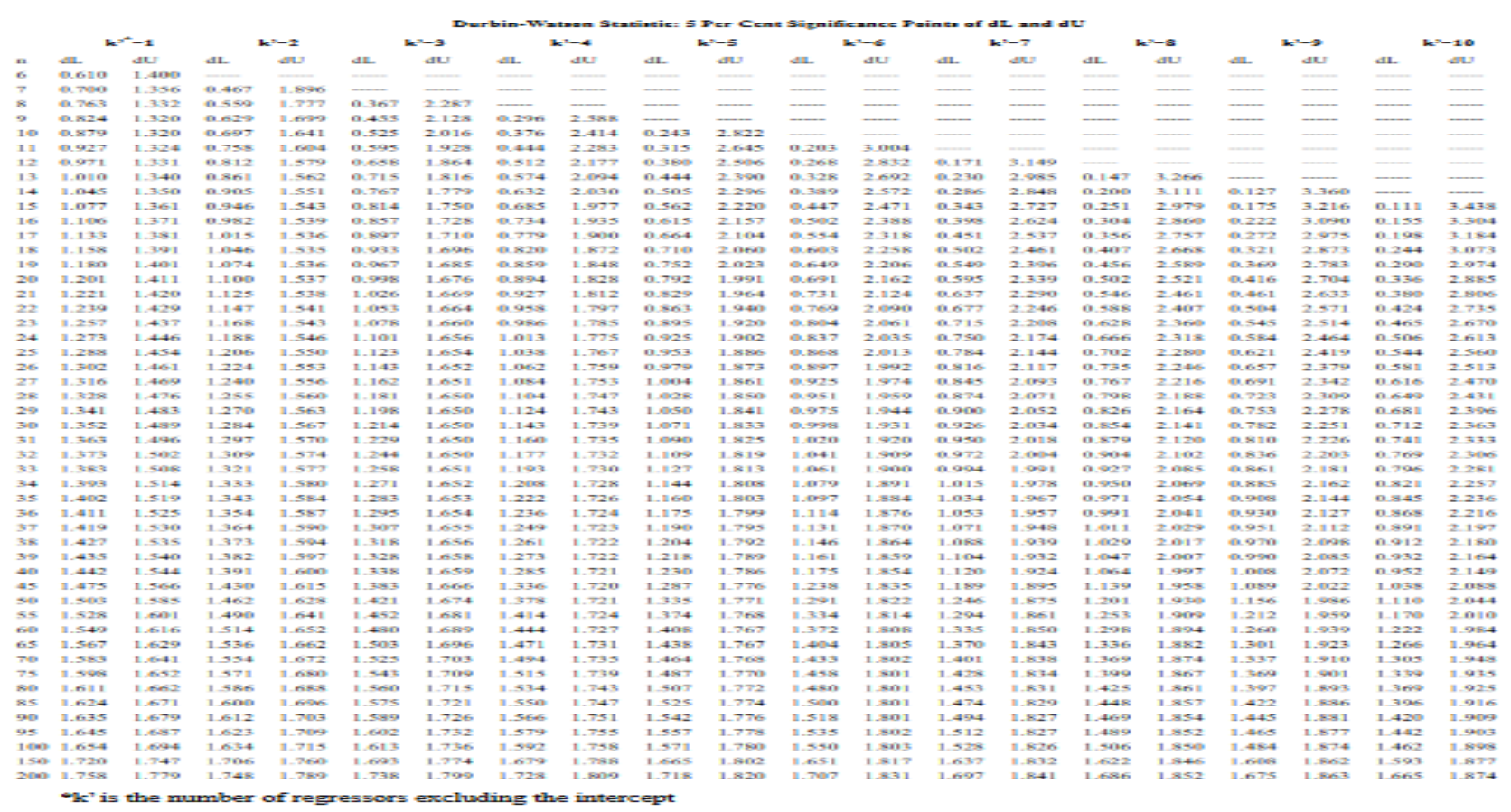




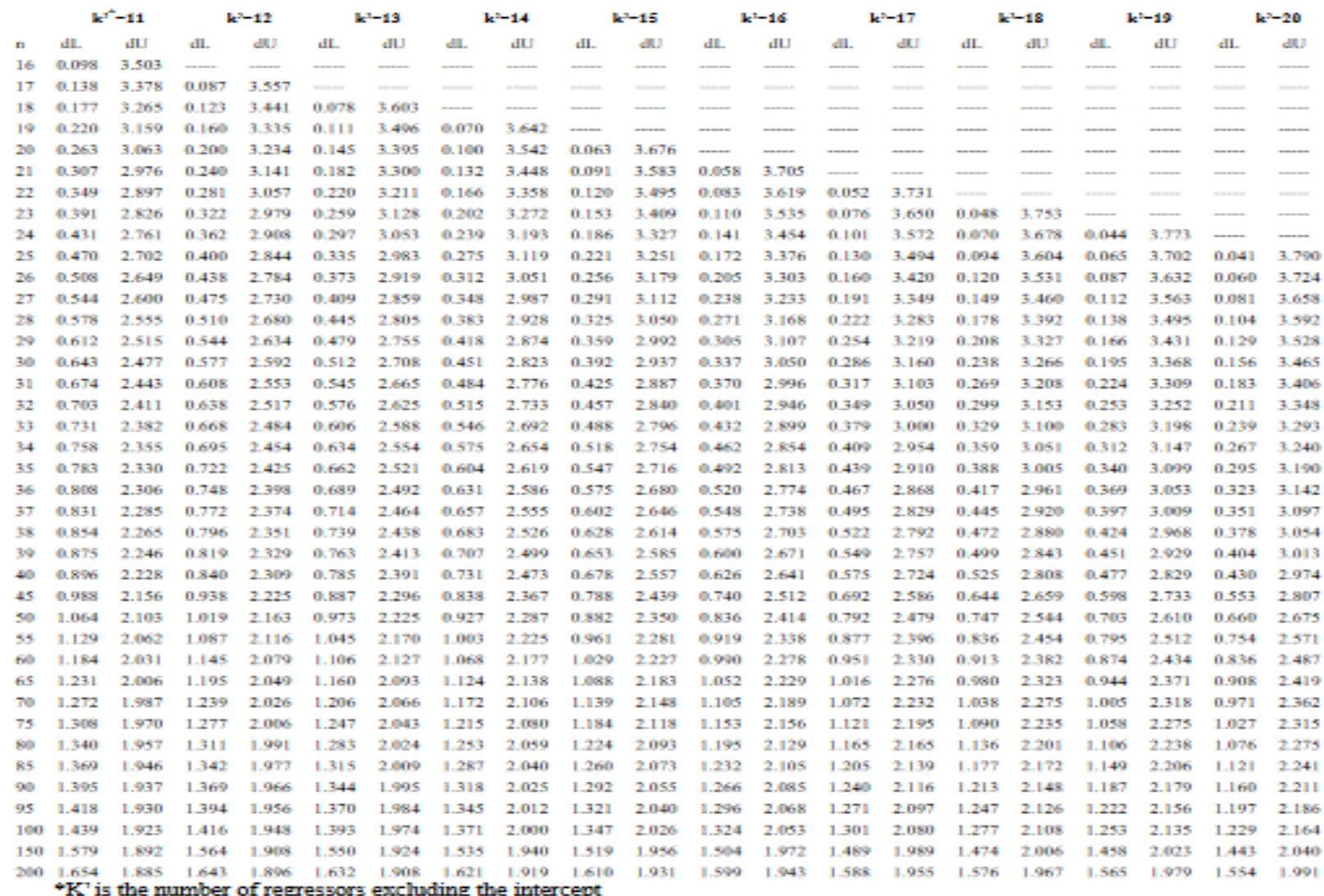

226 
